MÁRIO HENRIQUE CASTANHO PRADO DE OLIVEIRA

\title{
A ALIENAÇÃO PARENTAL COMO FORMA DE ABUSO À CRIANÇA E AO ADOLESCENTE
}

\author{
DisSERTAÇÃo de MESTRAdo \\ ORIENTADOR: Prof. Dr. ROBERTO JoÃo EliAS
}

FACULDADE DE DIREITO DA UNIVERSIDADE DE SÃO PAULO SÃO PAULO 


\section{A ALIENAÇÃO PARENTAL COMO FORMA DE ABUSO À CRIANÇA E AO ADOLESCENTE}

Dissertação apresentada ao Departamento de Direito Civil da Faculdade de Direito da Universidade de São Paulo, como requisito parcial para a obtenção do título de Mestre em Direito, sob a orientação do Professor Doutor Roberto João Elias. 


\section{FOLHA DE APROVAÇÃO}

Candidato: $\quad$ Mário Henrique Castanho Prado de Oliveira.

Natureza: $\quad$ Dissertação de Mestrado.

Instituição: $\quad$ Faculdade de Direito da Universidade de São Paulo.

Objetivo: $\quad$ Obtenção do título de Mestre em Direito.

Orientador: $\quad$ Professor Doutor Roberto João Elias.

Área de concentração: Direito Civil.

Data da banca:

Professor Doutor Roberto João Elias (Orientador).

Professor:

Titulação:

Instituição: Universidade de São Paulo.

Professor:

Titulação:

Instituição: 
Agradeço:

À minha família e aos meus amigos, pelo carinho, incentivo $e$, principalmente, por compreenderem que os largos periodos de ausência e afastamento eram parte imprescindivel do trajeto para alcançar este objetivo.

Ao meu orientador, Prof. Dr. Roberto João Elias, por acreditar em mim e no tema proposto.

Aos professores e aos colegas, pelo muito que aprendi durante as aulas e os seminários, através dos valiosos -e por vezes acalorados - debates.

Ao Prof. Dr. José Fernando Simão, pelos debates - dentro e fora da sala de aula -, pela amizade e pela confiança ao convidar-me a monitorar suas aulas, sempre fazendo tudo quanto podia para a consolidação dos meus ideais de magistério.

Ao Prof. Dr. Artur Marques da Silva Filho, por despertar em mim, no início da graduação, o interesse pelo Direito Civil, $e$ pela amizade desde então. 
Les enfants seuls savent ce qu'ils cherchent.

(Antoine de Saint Exupéry - Le Petit Prince) 


\section{RESUMO}

Com o crescente número de separações e divórcios verificados nas últimas décadas - no Brasil e no mundo - assistiu-se, também, a um exponencial aumento nas disputas envolvendo a guarda dos filhos menores e o direito de visitas. Essa situação de grave conflito familiar se mostra solo fértil para o acirramento de ânimos das partes, que frequentemente não são capazes de perceber que a falência do seu relacionamento conjugal em nada altera sua relação parental com os filhos comuns. Nesse cenário, em que as desavenças familiares já chegaram aos umbrais do Judiciário, não raro se verifica a tentativa, notadamente movida por sentimentos de vingança, de se afastar o genitor nãoguardião dos seus filhos, através de táticas e manobras - geralmente levadas a cabo pelo genitor guardião - aptas a efetivar tal distanciamento. A essa conduta se deu o nome de Alienação Parental, tema abordado pelo legislador brasileiro através da Lei 12.318, de 2010, que estabelece a reprovação estatal à conduta alienadora e fornece ao julgador elementos para identificá-la e repreendê-la. O presente trabalho visa, dessa maneira, por meio da análise dos estudos já realizados acerca da Alienação Parental e da Síndrome da Alienação Parental, identificar na conduta alienadora a configuração de verdadeiro abuso moral cometido contra a criança e o adolescente, por atentar contra o seu fundamental direito à convivência familiar com ambos os genitores.

PALAVRAS-CHAVE: Direito de Família - Criança e adolescente - Direito à convivência familiar - Abuso moral - Alienação Parental - Síndrome da Alienação Parental. 


\begin{abstract}
With the increasing number of separations and divorces in recent decades - in Brazil and throughout the world - there was also an exponential increase of disputes involving custody of the children and visitation rights. This situation of severe family conflict provides fertile ground to the intensification of hostilities between the parties, who often fail to realize that their connubial relationship's failure does not change their parental relationship with the mutual children. In this scenario, in which family quarrels have already reached the threshold of the judiciary, one can often see the attempt, notably motivated by feelings of revenge, to separate the non-custodial parent from his (her) children, through tactics and maneuvers - usually carried out by the custodial parent - that are able to accomplish such an estrangement. This behavior was named Parental Alienation, a subject addressed by the Brazilian act n. 12.318 of 2010, which established the state disapproval of the alienating actions and allowed the judge to identify and admonish them. Therefore, the present work aims, through the analysis of existing studies about Parental Alienation and Parental Alienation Syndrome, to consider alienating behaviors as a genuine form of moral abuse against children and adolescents, by undermining its fundamental right to family with both parents.
\end{abstract}

KEYWORDS: Family law - Child and adolescent - Right to family life - Moral abuse - Parental Alienation - Parental Alienation Syndrome. 


\section{SUMÁRIO}

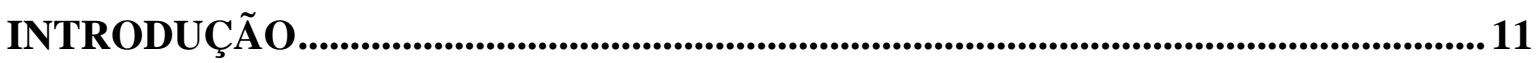

PARTE I - A PROTEÇÃO DA CRIANÇA E DO ADOLESCENTE NA FAMÍLIA EM CRISE

1. NOTA INTROdUTória: DO PATRIMônio AO AFETO - A FAMília CONSTITUCIONALIZADA ..................................................................................... 14

2. A PROTEÇÃO DA CRIANÇA E DO ADOLESCENTE ........................................ 21

2.1. Breve histórico do direito protetivo do menor ...................................................... 21

2.2. A doutrina do melhor interesse e da proteção integral como princípios absolutos 25

2.3. Conjugalidade e parentalidade: a convivência familiar ..................................... 31

2.4. O afeto como valor jurídico e o cuidado como dever objetivo .............................. 41

3. A GUARDA DOS FILHOS APÓS A SEPARAÇÃO DO CASAL ............................. 47

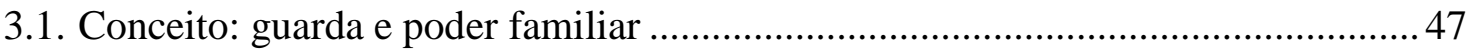

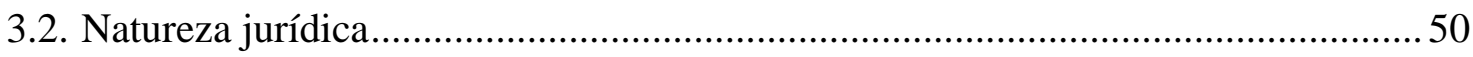

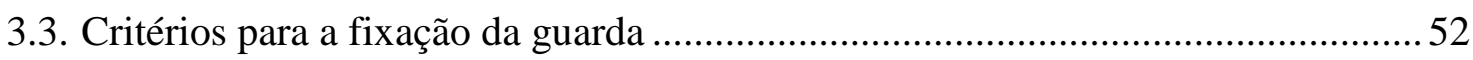

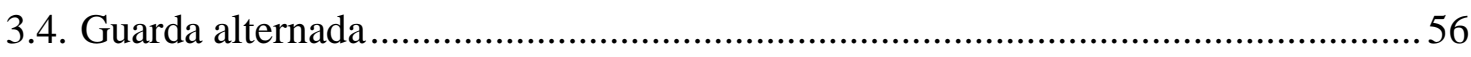

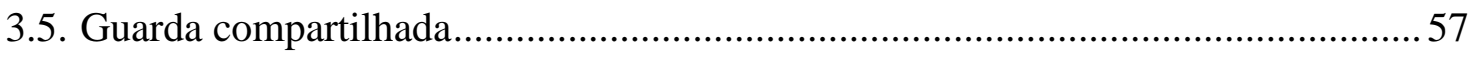

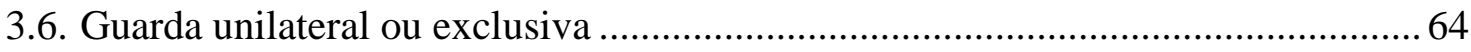

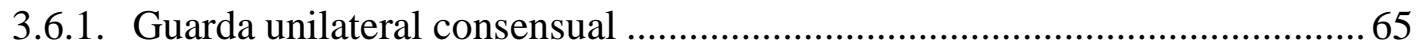

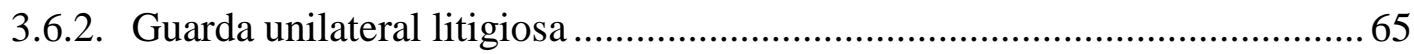

4. O DIREITO DE VISITAS DO GENITOR NÃO-GUARDIÃO ............................67

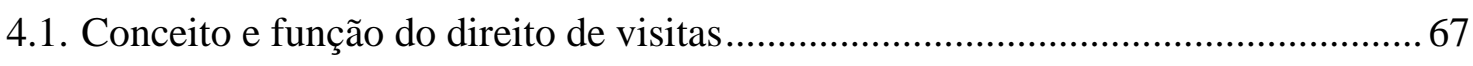

4.2. Natureza jurídica do regime de visitas: direito ou dever? ..................................69

4.3. Formas e critérios para a fixação do regime de visitas ............................................73

4.3.1. Regime fixado em comum acordo entre os genitores e regime determinado

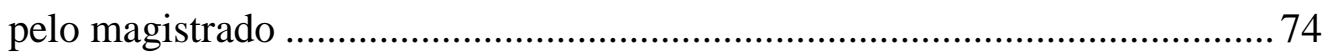

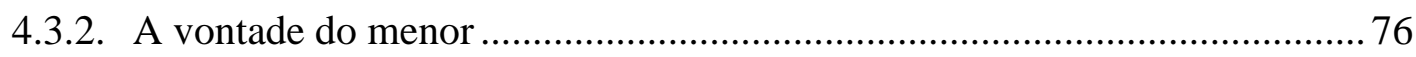


4.3.3. A regulamentação do direito de visitas ...................................................... 77

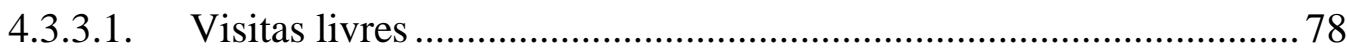

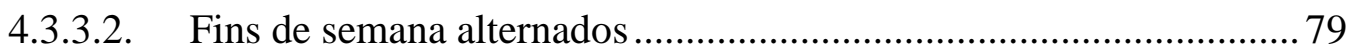

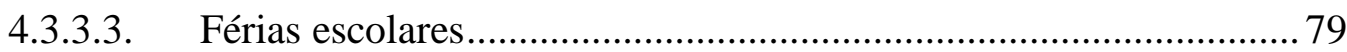

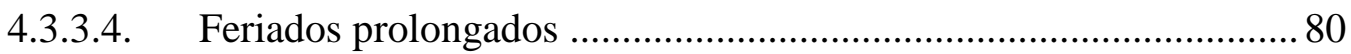

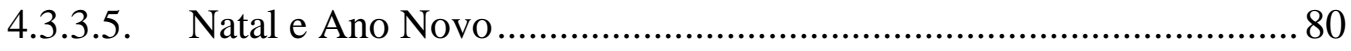

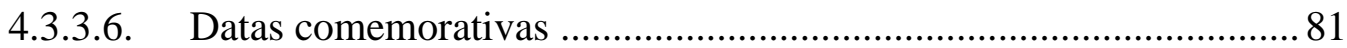

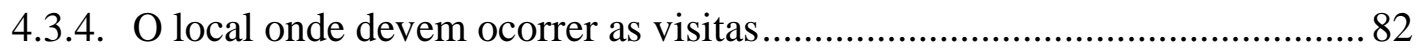

4.3.4.1. Visita na casa materna ou em berçário ............................................. 82

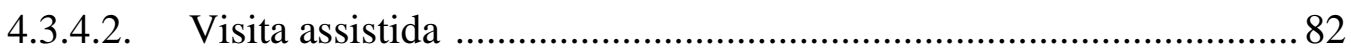

4.3.4.3. Visita em estabelecimentos especializados .................................. 84

4.4. Infração ao regime de visitas e medidas cabíveis para o seu cumprimento

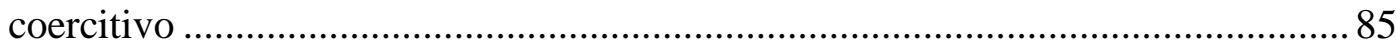

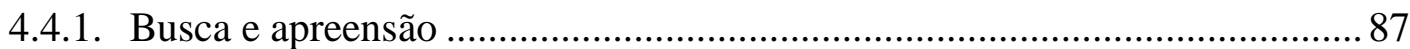

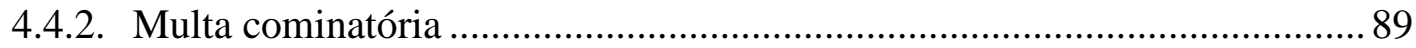

4.4.3. Inversão da guarda, suspensão e perda do poder familiar .......................... 90

4.4.4. Indenização por perdas e danos............................................................... 92

PARTE II - A ALIENAÇÃo PARENTAL COMO FORMA DE ABUSO À CRIANÇA E AO ADOLESCENTE..................................................................94

5. NOTA INTRODUTÓRIA: QUANDO O HEROI SE TORNA O VILÃO..............94

6. ALIENAÇÃO PARENTAL E A SÍNDROME DA ALIENAÇÃO PARENTAL 100

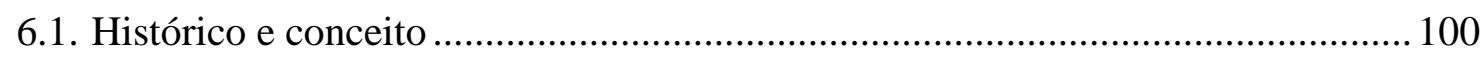

6.2. Alienação parental e síndrome da alienação parental.......................................... 106

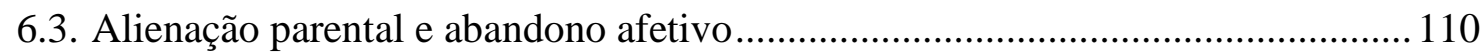

7. A INSTALAÇÃO DA ALIENAÇÃO PARENTAL .................................................118

7.1. A disputa pela guarda como palco da alienação parental .................................. 118

7.2. Alienação parental e alegação de abuso sexual .................................................. 119

7.3. Manifestações da alienação parental na criança ................................................. 122

7.4. Manifestações da alienação parental no genitor alienador ................................... 129

7.5. Reflexos da alienação parental no genitor alienado ........................................... 134 
8.1. Alienação parental como forma de abuso à criança e ao adolescente .................. 137

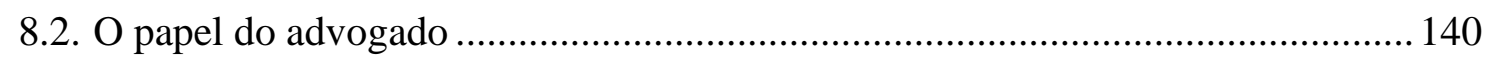

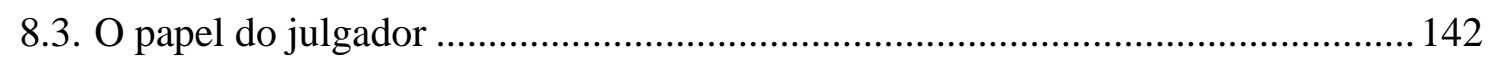

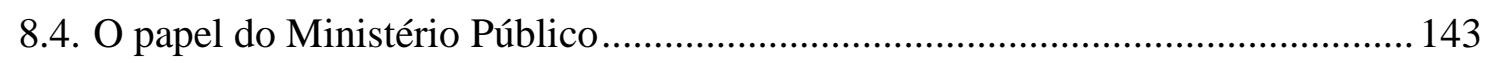

8.5. O papel da equipe multidisciplinar e do assistente técnico ................................. 144

8.6. Lei 12.318/2010 - Lei da Alienação Parental - muitos elogios, algumas críticas e

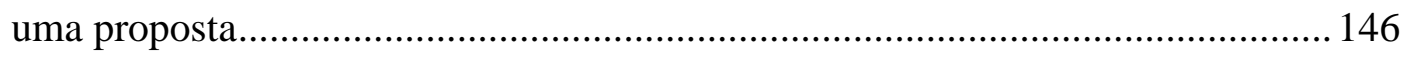

8.7. Combate à obstrução do direito de convivência familiar em legislações

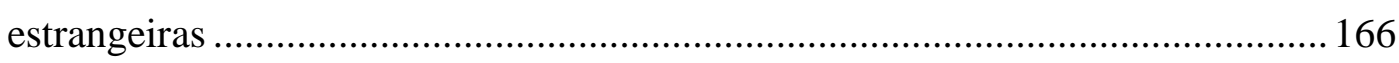

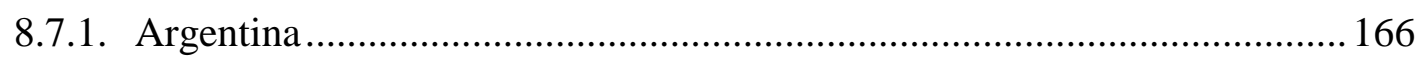

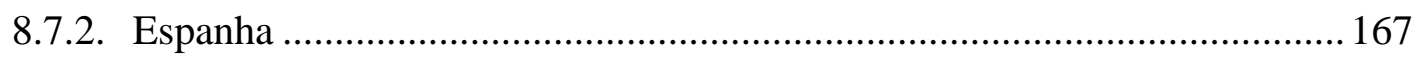

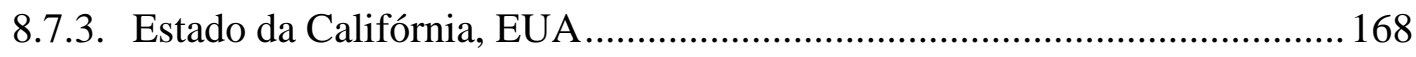

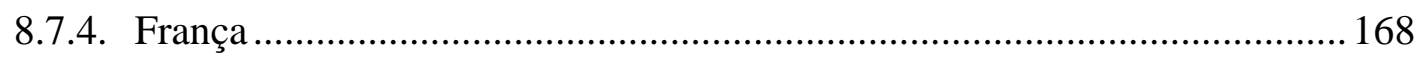

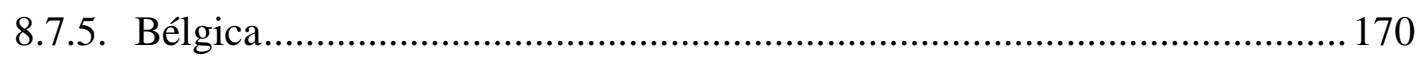

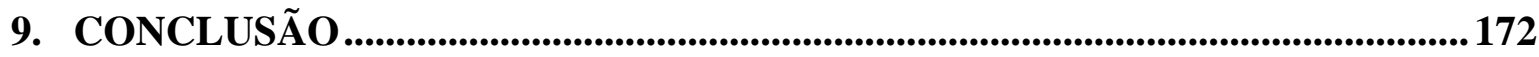

REFERÊNCIAS BIBLIOGRÁFICAS ........................................................................... 175 


\section{INTRODUÇÃO}

Os desentendimentos decorrentes da separação do casal, especialmente quando se dá de forma litigiosa e desgastante, geralmente produzem efeitos severos nos filhos, que tendem a ter sua guarda deferida a apenas um dos ex-cônjuges (ou ex-companheiros) justamente pela ausência de acordo entre aqueles que formavam o casal.

Ao genitor que viu deferida contra si a guarda dos filhos geralmente é concedido o direito de visita, que na verdade se trata de um poder-dever: o progenitor não apenas pode, mas deve acompanhar e colaborar para com o desenvolvimento de seus filhos.

A decisão judicial que concede o direito de visitas não visa exclusivamente a atender ao anseio do progenitor em manter contato com seus filhos: visa, antes, garantir que a criança ou o adolescente seja acompanhado tanto pela figura materna quanto pela paterna durante o seu desenvolvimento. A própria Constituição Federal garante à criança e ao adolescente, em seu art. 227, o direito “à convivência familiar e comunitária”.

Contudo - e infelizmente -, não raro observar-se que o fim da relação entre os genitores gera entre ambos uma série de sentimentos negativos, tais como a raiva, a inveja, o ressentimento, o desejo de vingança, principalmente quando a relação termina em decorrência de abandono ou adultério por parte de um deles. Havendo filhos menores, e não dispondo os ex-cônjuges (ou companheiros) de um mínimo de equilíbrio emocional e sensatez, aqueles filhos fatalmente sofrerão as consequências do desafeto que seus pais mutuamente desenvolveram após o fim de seu relacionamento.

Por conta de tais sentimentos negativos é que o detentor da guarda dos filhos menores poderá tentar afastá-los do seu outro genitor, promovendo uma verdadeira campanha de difamação que objetiva, principalmente, destruir a relação de afetividade existente entre o genitor não-guardião e os filhos, ou impedir que tal relação venha a se estabelecer. A tal atitude se dá o nome de alienação parental.

O termo foi cunhado nos Estados Unidos, na década de 1980, pelo Dr. Richard Alan Gardner, que estudou as causas e as consequências daquilo que chamou de Síndrome da Alienação Parental. Muito embora haja críticas relacionadas à caracterização da alienação parental como uma síndrome no sentido estrito, para o presente estudo importam, de fato, os atos praticados pelo guardião no sentido de obstaculizar o direito à convivência familiar dos filhos com o outro genitor. 
Conforme expressa determinação constitucional, repetida e alargada no Estatuto da Criança e do Adolescente, o menor tem especial proteção do Estado, sendo dever, portanto, não apenas da família, mas da sociedade como um todo, zelar por sua segurança e seu desenvolvimento. Portanto, o poder familiar exercido pelos pais sobre os filhos mormente após a separação dos genitores e a atribuição da guarda a apenas um deles deve servir, sempre, à proteção integral dos filhos, e aos seus melhores interesses - que englobam, dentre outros fatores, o direito à convivência familiar saudável com ambos os genitores e demais membros do grupo familiar. A sua obstaculização, portanto, ao contrário do que muitos guardiães tendem a imaginar, não é parte dos poderes que lhes são atribuídos para viabilizar a criação dos filhos menores: trata-se de uma expressa violação a direito, possivelmente configuradora de ato de alienação parental, e, dessa forma, punível de acordo com as normas vigentes.

Deve-se atentar para o fato de que, frequentemente, a alienação parental apresenta enorme dificuldade em ser identificada pela autoridade judicial. Não apenas porque o julgador não está especificamente preparado para identificar seus possíveis indícios e sintomas, mas também porque o genitor alienador realiza no menor verdadeira lavagem cerebral, e muitas vezes a criança passa a acreditar naquilo que lhe foi dito contra o genitor alienado, contribuindo ela mesma na campanha de difamação deflagrada pelo alienador. Não raro uma falsa denúncia de violência cometida contra a criança ou o adolescente, ou até mesmo de abuso sexual, pode ensejar, de uma vez por todas, a aniquilação do seu convívio com o genitor alienado.

Uma vez que o fenômeno da alienação parental se instala no menor, graves consequências poderão advir, obstruindo o seu saudável e normal desenvolvimento, passando a criança a revelar diversos sintomas, mostrando-se ansiosa, agressiva e, por vezes, até mesmo deprimida.

A escassez de material sobre o tema, especialmente na área jurídica, contribui para a dificuldade na constatação judicial da alienação parental posta em marcha pelo genitor alienador, uma vez que avaliar os fatores que podem demonstrar a ocorrência da alienação parental, no caso concreto, não é tarefa simples. Além disso, quanto mais tempo se leva para intervir no processo de alienação, mais difícil é a sua reversão. O rompimento da relação afetiva entre a criança e o genitor alienado pode se dar de forma tão grave que sua reconstrução, se possível, poderia levar anos.

A prioritária e integral proteção do menor demandam, inelutavelmente, que o Judiciário faça o possível para coibir a alienação parental, buscando minimizar as chances 
de instalação do correspectivo fenômeno. Identificado o processo de alienação, seu desenvolvimento deve ser imediatamente abortado, sob pena de causar ao menor consequências psicológicas por vezes irreversíveis.

Em 26 de agosto de 2010 foi sancionada a Lei 12.318 - Lei da Alienação Parental, que, além de conceituar o fenômeno e elencar, exemplificativamente, o rol de condutas configuradoras da alienação parental, estabeleceu diversas medidas a serem tomadas pelo julgador - dentre as quais a advertência, a multa, a inversão da guarda e até mesmo a suspensão do poder familiar - para obstar a prática de atos alienadores.

No presente trabalho buscar-se-á demonstrar, dessa maneira, que o Direito garante à criança e ao adolescente, com absoluta prioridade, a proteção dos seus melhores interesses. Dentre eles se encontra o direito à convivência familiar com ambos os genitores, direito esse que, em casos de severos conflitos familiares envolvendo a disputa pela guarda e o direito de visitas, pode ser obstaculizado pelo guardião do menor, configurando-se a alienação parental. Assim, será importante atentar para a forma pela qual se dá a alienação parental, quem são seus atores, quais as suas características, seu modus operandi, e, principalmente, quais as medidas jurídicas cabíveis para evitar a tragédia familiar que, muitas vezes, transforma crianças em órfãs de pais vivos. 


\title{
PARTE I - A PROTEÇÃO DA CRIANÇA E DO ADOLESCENTE NA FAMÍLIA EM CRISE
}

\section{NOTA INTRODUTÓRIA: DO PATRIMÔNIO AO AFETO - A FAMÍlIA CONSTITUCIONALIZADA}

A família não é, em sua origem, uma instituição, muito embora o Direito assim a reconheça. Existe muito antes do Direito, sendo um fenômeno observável não apenas na espécie humana - nesta sendo, porém, certamente muito mais desenvolvido. É fenômeno que entrelaça aspectos biológicos, sociológicos e psicológicos dos indivíduos, que não escapa, contudo, à modelagem pelo Direito ${ }^{1}$.

Desse modo, apesar da família não dever sua existência - nem sua evolução - ao Direito, este pode - como faz - traçar-lhe contornos, impondo-lhe regramentos que visam, ultima ratio, não a uma interferência arbitrária, mas à sua proteção.

A família é o menor núcleo social que um indivíduo pode conhecer. É, via de regra, partindo dela que busca sua realização pessoal, através da formação intrafamiliar. É a base da sociedade, pois não foi a partir de outro núcleo que a humanidade se desenvolveu. Nesse sentido expõe CARLOS ALBERTO BITTAR:

\begin{abstract}
A família cumpre certas finalidades básicas no mundo fático, a partir da concepção universalmente aceita de que é a célula vital do organismo social: a primordial, a de gerar e de formar outras pessoas para a perpetuação do gênero humano; a conseqüente, a de contribuir para a manutenção e o desenvolvimento do Estado, inserindo em seu meio pessoas preparadas para a vida social ${ }^{2}$.
\end{abstract}

Assim, não por outro motivo a preocupação em se proteger a família foi plasmada na própria Constituição Federal, no caput do art. 226, que expressamente lhe confere $a$ especial proteção do Estado. Todo o regramento a que o Direito submete a família, ainda que importe em restrições e deveres, possui como escopo, como objetivo último, a sua proteção - e, dessa forma, a proteção dos seus membros ${ }^{3}$.

\footnotetext{
${ }^{1}$ CARBONNIER, Jean. Droit civil, t. 2, 21. ed. Paris: PUF, 2002, p. 7.

2 BITTAR, Carlos Alberto. Novos rumos do Direito de Família. In: BITTAR, Carlos Alberto (coord). $O$ Direito de Família e a Constituição de 1988. São Paulo: Saraiva, 1989, p. 4.

${ }^{3}$ Ainda nas palavras de Carlos Alberto Bittar, "inobstante a ênfase personalista (...), as reformas não têm olvidado o aspecto institucional do relacionamento familiar, ditando, a cada passo, regras limitativas da ação individual no interesse do conjunto, tanto pessoais quanto patrimoniais", op. cit., p. 25.
} 
Também dentro da família, portanto, observam-se os princípios protetores dos direitos e garantias fundamentais, tais como a igualdade e a dignidade da pessoa humana. $\mathrm{E}$ de outro modo não poderia ocorrer: o direito de família - talvez o mais público dos direitos privados $^{4}-$ é intensamente irradiado pelos princípios constitucionais.

Um dos mais relevantes desses princípios constitucionais, aplicável à família, é o da igualdade. Após um longo período de preponderância do "pai da família" (claro resquício romano), a igualdade (ao menos formal) finalmente se fez entre o homem e a mulher, de forma integral. São iguais não apenas entre si, mas também em relação aos filhos. Incogitável, assim, qualquer preponderância de um sobre o outro, conforme estabelecem o § 6. ${ }^{\circ}$ do art. 226 da Constituição Federal de 1988 e o art. 1.511 do Código Civil de 2002.

A igualdade também se espraiou para a filiação, que, na medida do mesmo $\S 6 .^{\circ}$ do art. 227 da Constituição, colocou no mesmo plano todos os filhos - havidos ou não no casamento, incluindo também os filhos adotivos - vedando quaisquer designações discriminatórias.

Insta ressaltar que não se objetiva, aqui, tecer uma detalhada e profunda análise das transformações pelas quais a família passou ao longo dos séculos - tal fugiria ao escopo do presente estudo. Panoramicamente, contudo, é necessário que se delineie alguns pontos, com a finalidade de se compreender, ao final, que as transformações por que passou a família explicam muitas das situações que serão descritas ao longo deste trabalho.

\footnotetext{
${ }^{4}$ O que não significa que o Direito de Família esteja imerso no Direito Público, e não no Direito Privado. O fato de a Lei conceder ao Direito de Família um tratamento diferenciado, com uma maior interferência por parte do Estado, não possui o condão de transmigrar tal ramo do Direito Civil para o Direito Público. De pública a família possui apenas a proteção, pois é a família - depois apenas da própria consciência - o âmbito mais privado do indivíduo. Qualquer ingerência que se lhe aplique ocorrerá visando à sua proteção e à de seus membros, em reconhecimento, por parte do Estado, à sua importância para a conformação da sociedade. Nesse sentido posiciona-se Guillermo Borda, para quem "la pretensión de desglosar la familia del derecho privado importa un desconcertante contrasentido. Pues puede concebirse algo más privado, más hondamente humano que la familia, en cuyo seno el hombre nace, vive, ama, sufre y muere? Donde sino en ella puede refugiarse la privacidad? Las que propugnan la segregación del derecho de familia del privado, consciente o inconsciente preparan el camino hacia un intolerable intervencionismo estatal en la vida íntima de la familia" (BORDA, Guillermo. Manual de Derecho de Familia. Buenos Aires: Perrot, 1988, p. 8). Maria Berenice Dias também destaca o caráter não-público do Direito de Família, classificando-o como um "microssistema jurídico, a merecer tratamento legal autônomo, um Código apartado da codificação civil". Ressalta a autora que "vem progredindo a inovadora ideia de a ciência da família vir a ser disciplina interdisciplinar autônoma, na procura de analisar e explicar, se possível de forma plena, dimensões da vida familiar conjunta e possivelmente encontrar regularidades na conexão entre família e sociedade" (DIAS, Maria Berenice. Manual de Direito das Famílias. 8. ed. rev. e atual. São Paulo: Ed. RT, 2011, p. 35). Ainda nesse sentido, opina Marcelo de Oliveira Milagres, para quem "O direito de família, para muitos autores, é considerado o mais público dos ramos do direito privado. Suas normas, por serem objeto da intensa preocupação protetiva do Estado, diminuindo o alcance do poder de autodeterminação dos membros da entidade familiar, seriam, em regra, cogentes. Todavia, várias são as hipóteses de valorização dos espaços de autonomia sob a influência do princípio da mínima intervenção estatal. Se o direito de família é considerado o mais público dos ramos do direito privado, no âmbito deste seria o mais pessoal, com preocupação eminentemente voltada para a pessoa humana" (MILAGRES, Marcelo de Oliveira. Normas cogentes e dispositivas de direito de família. Revista de Direito Privado, n. ${ }^{\circ} 35$, jul. 2008. p. 211-228).
} 
Assim, a evolução da família, como se percebe, de um modelo patriarcal e opressor para o modelo contemporâneo, liberal, democrático, ensejou também o aprimoramento do direito que se lhe aplica. De tal aprimoramento, que efetivamente se estendeu a todo o direito de família, merece especial destaque, para o presente estudo, a relação paternofilial.

WASHINGTON DE BARROS MONTEIRO ${ }^{5}$ lembra que, em Roma, o instituto do poder familiar era perfeitamente organizado, e que, "primitivamente, no direito romano, a patria potestas visava tão-somente ao exclusivo interesse do chefe de família", mas que "com o decorrer do tempo, entretanto, restringiram-se os poderes outorgados ao chefe de família", reduzindo-se "o absolutismo opressivo dos pais a simples direito de correção".

A posição dos filhos dentro da família foi, pois, se alterando, deixando eles de serem meros objetos de direito para se tornarem verdadeiros sujeitos de direito - inclusive sujeitos ativos. Em verdade, o caráter absoluto do poder parental sobre os filhos já há muito vem sendo relativizado, pois mesmo a patria potestas romana foi sendo gradativamente abrandada, especialmente a partir do início do período pós-clássico, vindo, ainda no direito Justinianeu, a conformar-se mais com o entendimento moderno de pátrio poder $^{6}$.

E a evolução dessa relação paterno-filial não se deteve, pois também a ideia já abrandada de pátrio poder se mostrou, com o passar do tempo, inadequada à função que a autoridade parental realmente deve cumprir na família e na sociedade. Como foi bem observado pela socióloga francesa IRÈNE THÉRY, “a autoridade parental não possui mais o autoritarismo que podia ser encontrado no antigo pátrio poder. É um direito-função, que não se pode exercer senão no interesse de seu beneficiário: a criança"7 (sem grifo no original).

Seguindo essa linha de raciocínio, GUSTAVO TEPEDINO relembra que

A relação entre pais e filhos apresenta-se, na atualidade, como processo dialógico, que substitui o anterior estado de subordinação no qual o filho figurava como sujeito passivo de mecanismo autoritário - estático e unilateral - de transmissão de informações. Torna-se indispensável, portanto, que a relação parental seja examinada em seu perfil dinâmico, no âmbito do processo

\footnotetext{
${ }^{5}$ MONTEIRO, Washington de Barros. Curso de Direito Civil - Direito de Família, v. 2. 39. ed. São Paulo: Saraiva, 2009, p. 413.

${ }^{6}$ ALVES, José Carlos Moreira. Direito romano. 14. ed., 3. tir. Rio de Janeiro: Forense, 2010, p. 621, it. 277.

7 THÉRY, Irène. Couple, filiation et parenté aujourd'hui - le droit face aux mutations de la famille et de la vie privée. Paris: Odile Jacob, 1998, p. 190. Tradução livre de “[...] l'autorité parentale n'as pas plus rien de l'autoritarisme que l'on pouvait percevoir dans l'ancienne puissance paternelle. C'est un droit-fonction, qui ne peut s'exercer que dans l'intérêt de son bénéficiaire : l'enfant'.
} 
educacional, de modo a que os filhos possam, aos poucos, libertarse da vulnerabilidade inerente ao natural déficit de maturidade que lhes é característico, decrescendo-se, progressivamente, em consequiência, o grau de intervenção dos pais sobre o seu discernimento e sua vontade, supridos, em intensidade variada, durante a incapacidade ${ }^{8}$.

Nesse sentido, tanto o constituinte de 1988 quanto o legislador infraconstitucional que lhe seguiu reconheceram que, muito mais do que direitos, os pais possuem, sim, deveres em relação aos filhos. Estes possuem preferência absoluta sobre os demais membros da família, decorrência do princípio da proteção integral da criança e do adolescente $^{9}$, que deve se efetivar através do fornecimento de tudo quanto seja necessário ao pleno desenvolvimento de sua personalidade ${ }^{10}$.

No entanto, cumpre mencionar que a proteção que o Estado estendeu aos filhos, conforme reconhecido pela doutrina da proteção integral e do melhor interesse, transborda o paternalismo assistencialista que um dia visou apenas garantir a saúde e a educação das crianças e dos adolescentes. O sentido de proteção integral, de garantia do melhor interesse, como se verá, é o de proporcionar aos menores condições de que se desenvolvam em sua plenitude, tornando-se os adultos que deverão, um dia, proteger e auxiliar as futuras crianças e adolescentes.

Tal preocupação com a relação paterno-filial, que por muito tempo - a despeito dos progressivos avanços - foi palco, em maior ou menor escala, da arbitrariedade do chefe da família, deveu-se, em larga medida, à modificação no tratamento dado pelo Direito às relações familiares. O Código Civil de 1916, monumento jurídico, em harmonia com seu esprit du siècle, trazia, mesmo anos antes da Constituição de 1988 e da lei civil que o substituiu, um regramento ao Direito de Família que já não mais se afinava perfeitamente com a evolução das próprias relações familiares.

Da simples leitura dos dispositivos atinentes ao Direito de Família, no Código de 1916, é possível perceber que, primordialmente, o patrimônio fora a tônica que orientara a preocupação do legislador.

Contudo, mesmo antes da promulgação da Constituição de 1988 e do advento do Código Civil de 2002, percebia-se uma mobilização, notadamente doutrinária - mas

\footnotetext{
8 TEPEDINO, Gustavo. A tutela constitucional da criança e do adolescente: projeções civis e estatutárias. In: CHINELLATO, Silmara Juny; SIMÃO, José Fernando; FUJITA, Jorge Shiguemitsu; ZUCCHI, Maria Cristina (orgs.). Direito de Família no Novo Milênio: estudos em homenagem ao Professor Álvaro Villaça Azevedo. São Paulo: Atlas, 2010, p. 417.

${ }^{9}$ Que será analisado de forma mais detalhada a seguir.

${ }^{10}$ ELIAS, Roberto João. Direitos fundamentais da criança e do adolescente. São Paulo: Saraiva, 2005, p. 2.
} 
também jurisprudencial, e mesmo legislativa -, no sentido de inverter-se o foco da preocupação legal no Direito de Família. Não que as questões patrimoniais, econômicas, não fossem importantes, mas sensação era a de que, sob a égide do Código de 1916, o patrimônio era a alma da família - em torno e em função dele ela se estruturava e se organizava. A pessoa parecia ficar em segundo plano, e tal situação já não era mais compatível com o pensamento preponderante. Era preciso centralizar o Direito de Família nas pessoas, e não no patrimônio. Era preciso repersonalizar o Direito de Família.

Nesse sentido PAULO LUIZ NETO LÔBO, por ocasião do advento da Constituição de 1988, lembra que:

Durante os trabalhos da Subcomissão da Família, do Menor e do Idoso [da Assembleia Nacional Constituinte], das 5.517 sugestões oriundas da população e concernentes à família, listadas pelo Relator, poucas, e mesmo assim relacionadas com assistência, têm cunho econômico. Destacaram-se os seguintes temas: fortalecimento da família; igualdade entre o homem e a mulher; guarda dos filhos; proteção da privacidade da família diante da mídia e da informática; proteção estatal das famílias dos carentes e presidiários; aborto; controle de natalidade; paternidade responsável; liberdade quanto ao controle de natalidade; integridade física, mental e moral dos membros da família; vida comunitária; amparo legal às uniões estáveis; igualdade dos filhos de qualquer condição; responsabilidade social e estatal pelos menores abandonados; melhoria do nível de vida; facilidade legal para a adoção (sem grifo no original) ${ }^{11}$.

Assim, a família que ganhou espaço privilegiado na Constituição não é mais aquela de antanho, em que preponderavam os aspectos materiais, patrimoniais, em detrimento daquilo que realmente transforma um grupo de pessoas numa família: o afeto. Nesse sentido, CAIO MÁRIO DA SILVA PEREIRA ressalta que:

Os vínculos de afetividade projetam-se no campo jurídico como a essência das relações familiares. $\mathrm{O}$ afeto constitui a diferença específica que define a entidade familiar. É o sentimento entre duas ou mais pessoas que se afeiçoam pelo convívio diuturno, em virtude de uma origem comum ou em razão de um destino comum que conjuga suas vidas tão intimamente, que as torna cônjuges quanto aos meios e aos fins de sua afeição até mesmo gerando efeitos patrimoniais, seja de patrimônio moral, seja de patrimônio econômico ${ }^{12}$.

\footnotetext{
${ }^{11}$ LÔBO, Paulo Luiz Neto. A repersonalização das relações de família. In: BITTAR, Carlos Alberto (coord.). O Direito de Família e a Constituição de 1988. São Paulo: Saraiva, 1989, p. 56-57.

${ }^{12}$ PEREIRA, Caio Mário da Silva. Instituições de Direito Civil, vol. V - Direito de Família. 17. ed. rev. e atual. por Tânia da Silva Pereira. Rio de Janeiro: Forense, 2009, p. 33.
} 
Percebe-se, portanto, a importância que a afetividade possui não apenas nas relações familiares, mas também - e, para o objeto do presente estudo, principalmente para os efeitos jurídicos decorrentes de tais relações.

A Constituição de 1988 foi um divisor de águas no que se refere ao tratamento dado pelo Direito à família e às relações que nela se desenvolvem, sofrendo estas uma incidência direta dos novos princípios constitucionais. Assim, nesse sentido da constitucionalização do Direito Civil, notadamente do Direito de Família, menciona-se, a título exemplificativo, o fim da distinção entre os filhos (havidos ou não dentro do casamento), e a evolução que modernizou a dissolução do casamento ${ }^{13}$, encontrando seu ápice na Emenda Constitucional 66/2010. Com a alteração do $§ 6 .^{\circ}$ do art. 226, retirou-se do divórcio o requisito da separação judicial ou de fato, permitindo-se, assim, que um casamento seja celebrado num dia e desfeito no dia seguinte, sem atribuições de culpas ou responsabilidades pelo fim da união. Reconheceu-se a união estável, hétero e homoafetiva, como formadora da entidade familiar. Encontra-se no passado, portanto, o casamento como exclusivo e legítimo instituidor da família.

Nesse passo, demolidos os motivos essencialmente patrimoniais que exigiam, por exemplo, a formalidade do casamento para a sua proteção pelo Estado, resta claro que aquilo que realmente forma - e transforma - uma família transcende o níquel. Assim opina PAULO LUIZ NETO LÔBO, para quem:

A família é, no presente, muito mais do que antes, o espaço de realização pessoal afetiva, despatrimonializada. A repersonalização de suas relações revitaliza a união familiar, em todas as suas manifestações sociais e não apenas a oficial, que renasce com outros fundamentos. O interesse a ser tutelado não é mais o do grupo organizado como esteio do Estado, e das relações de produção existentes, mas das condições que permitam à pessoa humana realizar-se íntima e afetivamente, nesse pequeno grupo social $^{14}$.

\footnotetext{
${ }^{13}$ Insta ressaltar que até a promulgação da Lei 6.515, de 1977, o casamento era indissolúvel no Brasil, e as Constituições até então traziam a regra antidivorcista. A Emenda que "promulgou" a Constituição de 1969 também mencionava a indissolubilidade do matrimônio, até que a Emenda Constitucional n. 09, de 1977, previu a possibilidade de se dissolver o casamento, apenas nas hipóteses expressas em lei, desde que houvesse prévia separação judicial por mais de três anos. Meses depois dessa alteração no parágrafo único do art. 175 da Constituição é que sobreveio a mencionada lei, inaugurando a disciplina da separação e do divórcio no Brasil. A Constituição de 1988, portanto, não inovou ao mencionar expressamente a possibilidade de dissolução o casamento; contudo, retirou alguns empecilhos à sua ocorrência, reduzindo para um ano o prazo do divórcio conversão (após prévia separação judicial), ou, no caso de divórcio direto, dois anos após a separação de fato.

${ }^{14}$ LÔBO, Paulo Luiz Neto. A repersonalização das relações de família. In: BITTAR, Carlos Alberto (coord). O Direito de Família e a Constituição de 1988. São Paulo: Saraiva, 1989, p. 74.
} 
Nota-se que a proteção dada pelo Estado à família, seja através da letra constitucional ou das leis ordinárias, vem progressivamente perdendo esse viés materialista, em que se protegia o núcleo familiar como uma entidade, acima mesmo dos interesses dos seus membros. A família era mais importante, e portanto merecia maiores cuidados que os familiares, ou seja, aqueles que a compunham. Era possível, ainda, vislumbrar-se o romano, e também católico, caráter sagrado da família tradicionalmente instituída, dada sua importância para a manutenção e perpetuação da sociedade, e, assim, do próprio Estado.

É claro que a família ainda é protegida pelo Estado, e diferente não deve ser. Mas tal proteção deve se dar não à instituição da família, e sim aos seus integrantes. Conforme bem salientou Neto Lôbo, a família é o "espaço de realização pessoal afetiva", passando o Estado a tutelar não o "grupo organizado", mas sim garantir, através da proteção à família, que os indivíduos possuam um espaço seguro onde podem "realizar-se íntima e afetivamente". 


\section{A PROTEÇÃO DA CRIANÇA E DO ADOLESCENTE}

\subsection{Breve histórico do direito protetivo do menor}

Conforme se ressaltou, durante muito tempo os filhos foram objeto do poder paterno - poder esse que, em Roma, abrangia inclusive o direito de tirar a vida do filho (ius vitae necisque). Não eram sujeitos, mas objetos de direito ${ }^{15} 16$.

Em solo pátrio, o Código Civil de 1916 elencava algumas formas de proteção à pessoa dos filhos, mas não lhes conferia direitos que realmente assegurassem a sua proteção integral. No Capítulo II do Título IV, dedicou o legislador 5 artigos à matéria, e tratando, via de regra, os filhos menores como verdadeiros "bens" a serem partilhados entre os pais, após a dissolução da sociedade conjugal. Apenas no § 2. ${ }^{\circ}$ do art. 326, após a redação determinada pela Lei 4.121, de 1962, é que se ventilou a hipótese de atribuir-se a guarda dos filhos a pessoas diferentes dos pais, em caso de motivo grave. $\mathrm{O}$ art. 327, caput, por seu turno, permitia ao juiz que, também em caso de graves motivos, estipulasse um regime de guarda diferente do acordado entre os pais.

Salienta-se, ainda, que a regulamentação dada pelo Código Beviláqua ao exercício da autoridade parental - então chamado de pátrio poder - também não visava, primordialmente, a proteção dos filhos. Era nítido o caráter autoritário e quase arbitrário daquilo que, em verdade, deveria ser um múnus. É possível notar tal viés, por exemplo, ao

\footnotetext{
${ }^{15}$ Em artigo sobre a evolução da proteção da criança e do adolescente no âmbito internacinal, Gustavo Ferraz de Campos Mônaco expõe que "em um passado não muito remoto as crianças não eram titulares de direitos, mas apenas se sujeitavam ao poder familiar. Casos houve em que a defesa de sua vida e de sua condição humana precisou ser feita com base em leis existentes para a proteção dos animais, sob o argumento de que, assim como os animais, as crianças eram seres vivos pertencentes ao reino animal - em contraposição, por óbvio, ao reino vegetal, que não gozaria de tal proteção. Um dos casos mais impressionantes ocorreu em Nova York, no ano de 1874, quando uma assistente social da igreja, ao visitar uma família, encontrou acorrentada à cama uma menina, doente, subnutrida e maltratada. Como não havia nenhuma lei limitando o exercício do poder familiar ou mesmo uma lei que proibisse os abusos e os maus-tratos contra crianças, não havia norma específica com base na qual se pudesse pleitear a cessação do abuso. Foi com base na lei de proteção aos animais que agiram os defensores, sob o argumento de que tal lei proibia que maus-tratos fossem cometidos contra quaisquer seres vivos pertencentes ao reino animal!" (MÔNACO, Gustavo Ferraz de Campos. O décimo-quinto aniversário da Convenção sobre os Direitos da Criança - contributo para o aprofundamento e implementação do direito internacional dos direitos humanos. Revista dos Tribunais, n. ${ }^{\circ} 831$, jan. 2005, p. 132-146).

${ }^{16}$ Acerca da categorização da criança e do adolescente como objeto ou sujeito de direito, a socióloga francesa Irène Théry afirma que "parece fundamental, atualmente, abandonar a oposição estéril entre a criança-objeto e a criança-sujeito, e se voltar a uma leitura muito mais equilibrada da Convenção Internacional dos Direitos da Criança, que afirma expressamente em seu preâmbulo, e nos seus números artigos, o direito primordial da criança a ser protegida" (THÉRY, Irène. Couple, filiation et parenté aujourd'hui - le droit face aux mutations de la famille et de la vie privée. Paris: Éditions Odile Jacob, 1998, p. 162. Tradução livre de: "il semble fondamental aujourd'hui d'abandonner l'opposition stérile entre l'enfant-objet et l'enfant-sujet, et de revenir à une lecture beaucoup plus équilibrée de la Convention internationale des droits de l'enfant, qui affirme solennellement dans son préambule, et dans de très nombreux articles, le droit premier de l'enfant à être protégé").
} 
verificar-se que, de 19 artigos relativos ao pátrio poder, o legislador dedicou apenas dois àquilo que lembra vagamente a noção de medidas protetivas (art. 394, caput, que estabelece o abuso do pátrio poder como uma das formas de sua perda, e o art. 395, que em seus três incisos estabelece hipóteses específicas de perda do pátrio poder - castigos imoderados, abandono e a prática de atos contrários aos bons costumes).

Em 1927, através do Dec. 17.943-A, de 12 de outubro, instituiu-se o primeiro Código de Menores, que, ainda na República dos Estados Unidos do Brasil, visava à consolidação das "leis de assistencia e protecção a menores".

Conforme determinado pelo art. 1. ', "o menor, de um ou outro sexo, abandonado ou delinquente, que tiver menos de 18 annos de idade, será submettido pela autoridade competente ás medidas de assistencia e protecção contidas neste Codigo", reforçando a ideia de que proteção a criança ou adolescente, como preocupação do Estado, só ocorria em situações excepcionais, em que o menor estivesse em situação de grave risco abandonado (infante exposto) ou em delinquência.

Foi criado o Conselho de Assistência e Proteção aos Menores, na forma de uma associação de utilidade pública detentora de personalidade jurídica própria. Seus conselheiros, que eram nomeados pelo governo, tinham a função precípua de auxiliar o juízo de menores.

Esse primeiro Código de Menores consistia, portanto, mais num instrumento de vigilância dos menores, e eventualmente de proteção daqueles que eram vítimas da omissão da família e da sociedade, do que um diploma realmente fornecedor de amplos direitos e garantias a todas as crianças e adolescentes.

Mesmo o seu sucessor, e predecessor do Estatuto da Criança e do Adolescente, o Código de Menores (Lei 6.697) de 1979 não estendia à criança e ao adolescente a proteção que se fazia necessária, pois ainda restringia sua aplicação aos menores de dezoito anos que estivessem em situação irregular. Apenas as medidas preventivas eram estendidas a quaisquer menores (art. $1^{\circ}$ ). Dentre os seus mecanismos de funcionamento, inexistia espaço para a participação de outros atores, limitando-se aos poderes da autoridade policial judiciária e administrativa.

Contudo, apesar do Código de Menores de 1979 não tratar da proteção dos menores de forma ampla - não se aplicando a casos de menores que, embora tivessem sido vítimas da violação de seus direitos básicos, não estivessem em situação irregular - a garantia de 
proteção especial da criança e do adolescente foi mencionada expressamente pela primeira vez na Constituição de 1937 , em seu art. $127^{17}$.

A Carta seguinte, de 1946, suprimiu tal comando, prevendo apenas, em seu art. $164^{19}$, que o Estado deveria prestar assistência à infância e à adolescência, o que foi repetido pelo art. $167, \S 4 .^{\circ}$, da Constituição de $1967^{20}$, e pelo art. $175, \S 4 .^{\circ}$ da EC 1 , de $1969^{21}$.

No plano internacional, o embrião da necessidade de se atribuir aos menores uma especial proteção pelo Direito já se formava há muito tempo. Tal ideia de proteção especial havia sido evocada pela Liga das Nações, na Declaração de Genebra de 1924, e foi repetida pela Declaração Universal dos Direitos Humanos, da ONU, em $1948^{22}$, e expandiu-se para o conceito do "interesse maior da criança", mencionado na Declaração dos Direitos da Criança, em $1959^{23}$.

Além disso, a Convenção Americana sobre os Direitos Humanos (Pacto de São José da Costa Rica), de 1969 (ratificada pelo Brasil apenas em 1992) também faz menção à necessidade de se proteger a criança, em seu art. $19^{24}$.

17 “Art 127 - A infância e a juventude devem ser objeto de cuidados e garantias especiais por parte do Estado, que tomará todas as medidas destinadas a assegurar-lhes condições físicas e morais de vida sã e de harmonioso desenvolvimento das suas faculdades.

O abandono moral, intelectual ou físico da infância e da juventude importará falta grave dos responsáveis por sua guarda e educação, e cria ao Estado o dever de provê-las do conforto e dos cuidados indispensáveis à preservação física e moral.

Aos pais miseráveis assiste o direito de invocar o auxílio e proteção do Estado para a subsistência e educação da sua prole" (sem grifo no original).

19 “Art 164 - É obrigatória, em todo o território nacional, a assistência à maternidade, à infância e à adolescência. A lei instituirá o amparo de famílias de prole numerosa."

20 “Art 167 - A família é constituída pelo casamento e terá direito à proteção dos Poderes Públicos.

(...)

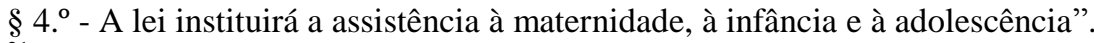

21 “Art. 175. A família é constituída pelo casamento e terá direito à proteção dos Podêres Públicos.

(...)

$\S 4 .^{\circ}$ Lei especial disporá sôbre a assistência à maternidade, à infância e à adolescência e sôbre a educação de excepcionais".

${ }^{22}$ Art. 25, (2): "Motherhood and childhood are entitled to special care and assistance. All children, whether born in or out of wedlock, shall enjoy the same social protection" (sem grifo no original).

${ }^{23}$ Notadamente em seu Segundo Princípio, que estabelece que "a criança gozará de proteção especial e disporá de oportunidade e serviços, a serem estabelecidos em lei por outros meios, de modo que possa desenvolver-se física, mental, moral, espiritual e socialmente de forma saudável e normal, assim como em condições de liberdade e dignidade. Ao promulgar leis com este fim, a consideração fundamental a que se atenderá será o interesse superior da criança". Vale mencionar que, no texto original, a expressão utilizada é "best interests of the child", que, conforme ressalta Tânia da Silva Pereira, enfoca um caráter qualitativo do interesse da criança (princípio do melhor interesse da criança), e não meramente quantitativo (princípio do superior interesse da criança). $O$ "melhor interesse da criança". In: PEREIRA, Tânia da Silva (coord.). $O$ Melhor Interesse da Criança: um debate Interdisciplinar. Rio de Janeiro: Renovar, 2000, p. 6.

${ }^{24}$ Artigo 19: "Toda criança tem direito às medidas de proteção que a sua condição de menor requer por parte da sua família, da sociedade e do Estado". 
Por fim, a Convenção sobre os Direitos da Criança, adotada pela Assembleia Geral da ONU em 20 de novembro de 1989, menciona o "interesse superior da criança" por diversas vezes (arts. 3, 9, 18, 20, 21, 37, 40). Tal Convenção foi ratificada pelo Brasil em 24 de setembro de 1990, e, através do Decreto n. 99.710, de 21 de novembro do mesmo ano, ingressou definitivamente no ordenamento jurídico brasileiro, ampliando o sentido da proteção integral e da observância ao melhor interesse da criança e do adolescente, no sentido de que:

os direitos inerentes a todas as crianças e adolescentes possuem características específicas devido à peculiar condição de pessoas em vias de desenvolvimento em que se encontram e que as políticas básicas voltadas para a juventude devem atuar de forma integrada entre a família, a sociedade e o Estado $^{25}$.

Em nosso país, foi com a Constituição de 1988 que se introduziu, ainda antes da Convenção sobre Direitos da Criança, a ideia de proteção diferenciada dos menores:

Art. 227. É dever da família, da sociedade e do Estado assegurar à criança e ao adolescente, com absoluta prioridade, o direito à vida, à saúde, à alimentação, à educação, ao lazer, à profissionalização, à cultura, à dignidade, ao respeito, à liberdade e à convivência familiar e comunitária, além de colocá-los a salvo de toda forma de negligência, discriminação, exploração, violência, crueldade e opressão (sem grifo no original).

$\mathrm{O} \S 3 .^{\circ}$ do aludido dispositivo menciona expressamente o "direito à proteção especial", elencando os aspectos mínimos em que tal proteção deve se efetivar, e o $\S 6^{\circ}$ estabelece a absoluta igualdade entre os filhos, qualquer que seja a sua origem (inclusive a adoção), proibindo quaisquer designações discriminatórias.

Menos de dois anos depois da Constituição, e substituindo o Código de Menores, entrou em vigor o Estatuto da Criança e do Adolescente (Lei 8.069, de 13 de julho de 1990), que veio estabelecer, em caráter definitivo, o princípio da proteção integral da criança e do adolescente:

Art. 3. A criança e o adolescente gozam de todos os direitos fundamentais inerentes à pessoa humana, sem prejuízo da proteção integral de que trata esta Lei, assegurando-se-lhes, por lei ou por outros meios, todas as oportunidades e facilidades, a fim de lhes facultar o desenvolvimento físico, mental, moral, espiritual e social, em condições de liberdade e de dignidade.

${ }^{25}$ PEREIRA, Caio Mário da Silva. Instituições de Direito Civil, vol. V - Direito de Família. 17. ed. rev. e atual. por Tânia da Silva Pereira. Rio de Janeiro: Forense, 2009, p. 45. 
Art. 4. ${ }^{\circ}$ É dever da família, da comunidade, da sociedade em geral e do poder público assegurar, com absoluta prioridade, a efetivação dos direitos referentes à vida, à saúde, à alimentação, à educação, ao esporte, ao lazer, à profissionalização, à cultura, à dignidade, ao respeito, à liberdade e à convivência familiar e comunitária (...) (sem grifo no original).

O "superior interesse da criança", do qual se tratará mais detalhadamente adiante, é também ressaltado em diversos dispositivos estatutários, alterados ou inseridos pela Lei Nacional da Adoção (12.010/2009): art. 19, § 2. '; art. 52-C, § 1. o; art. 100, parágrafo único, IV.

No plano internacional, salienta-se que diversos países constitucionalizaram expressamente a proteção da criança e do adolescente, sendo alguns: Islândia (art. 76), Espanha (seção 39), Portugal (arts. 69 e 70), Suíça (arts. 11 e 67), Alemanha (art. 6. ${ }^{\circ}$ ), Itália (art. 31), Venezuela (art. 78). Os Estados Unidos não tratam da matéria no plano constitucional, assim como a França - que, contudo, menciona o "interesse da criança" em diversos dispositivos do Código Civil.

\subsection{A doutrina do melhor interesse e da proteção integral como princípios absolutos}

Conforme se buscou demonstrar, a ideia de se incluir as crianças e os adolescentes numa categoria especial de sujeitos de direito é relativamente recente. É verdade que o intuito de proteção não é tão novo, contudo tal viés protetivo se devia muito mais à condição biologicamente desprivilegiada da criança em relação aos adultos do que ao reconhecimento de que, mais do que seres de menor força física, as crianças e os adolescentes são pessoas em desenvolvimento, também no aspecto físico, mas, e principalmente, psicológico, moral, social.

A fragilidade das crianças e dos adolescentes se dá em diversos aspectos, sendo o físico o menos importante deles. Proteger a fragilidade física dos menores requer apenas que se abstenha de agredi-la, propiciando-lhes sustento e proteção à saúde. Contudo, proteger a fragilidade psíquica, moral e social das crianças e dos adolescentes requer mais do que uma mera abstenção de agressão: é necessário que se tomem medidas positivas no sentido de guiar o desenvolvimento das crianças e dos jovens para que se tornem adultos saudáveis de corpo e mente.

Para garantir isso, a proteção da criança e do adolescente passou a envolver princípios que se destacam, a cada dia, como verdadeiros valores jurídicos. O Direito de Família contemporâneo tem priorizado as relações de afeto, solidariedade e 
responsabilidade, abandonando a identificação tradicional do grupo familiar como mero núcleo econômico e de reprodução ${ }^{26}$.

É nesse sentido que se verifica que os interesses relativos à criança e ao adolescente merecem prioridade em relação a quaisquer outros. Insta assentar, ainda, que não se protege apenas os interesses dos menores; busca-se, em verdade, a tutela dos melhores interesses da criança e do adolescente. Sobre o princípio do melhor interesse da criança, TÂNIA DA SILVA PEREIRA informa que se origina do parens patriae inglês, "utilizado na Inglaterra como uma prerrogativa do Rei e da Coroa a fim de proteger aqueles que não podiam fazê-lo por conta própria"27.

A Convenção de Haia sobre os Direitos das Crianças e dos Adolescentes enunciou de forma expressa tal especialidade de interesses. MARIA SANTOS PAIS, reportando-se ao texto da Convenção, lembra que:

De acordo com o artigo 3 da Convenção, o melhor interesse da criança será uma consideração primordial em todas as ações relativas às crianças, levadas a efeito por instituições públicas ou privadas social, os tribunais ou as autoridades administrativas ou legislativas . Isso significa que, em todas as circunstâncias e em qualquer decisão que afete uma criança, dever-se-á sempre escolher a melhor solução para $\mathrm{ela}^{28}$.

Nesse diapasão, ainda de acordo com a professora, o princípio do melhor interesse estabelece-se num critério fundamental para a resolução de conflitos que atinjam a esfera de interesse das crianças e adolescentes, devendo ser especialmente observado em todos os casos em que exista um conflito de interesses entre o menor e aqueles que detêm a sua guarda, inclusive seus pais ${ }^{29}$.

Buscando enunciar o que vem a ser o princípio do melhor interesse da criança, JEAN ZERMATTEN sugere que:

\footnotetext{
${ }^{26}$ PEREIRA, Tânia da Silva. Direito da criança e do adolescente - uma proposta interdisciplinar. 2. ed. rev. e atual. Rio de Janeiro: Renovar, 2008, p. 50.

${ }^{27}$ PEREIRA, Tânia da Silva. Direito da criança e do adolescente - uma proposta interdisciplinar. 2. ed. rev. e atual. Rio de Janeiro: Renovar, 2008, p. 42.

${ }^{28}$ PAIS, Maria Santos. Le meilleur intérêt de l'enfant. In: PEREIRA, Tânia da Silva Pereira (coord.). $O$ Melhor Interesse da Criança: um debate Interdisciplinar. Rio de Janeiro: Renovar, 1999, p. 542. Tradução livre de "Selon l'article 3 de la Convention, le meilleur intérêt de l'enfant sera une considération primaire lors de toute action qui concerne les enfants, qu'elle soit entreprise par des institutions sociales publiques ou privées, les tribunaux ou des autorités administratives ou législatives. Ceci signifie que, dans toutes les circunstances (sic) et lors de toute décision qui concerne un enfant, on doit toujours choisir la meilleure solution possible pour l'enfant."

${ }^{29}$ PAIS, Maria Santos. Le meilleur intérêt de l'enfant. In: PEREIRA, Tânia da Silva Pereira (coord.). $O$ Melhor Interesse da Criança: um debate Interdisciplinar. Rio de Janeiro: Renovar, 1999, p. 546.
} 
O melhor interesse da criança é um instrumento jurídico que visa garantir o bem-estar da criança nos planos físico, psíquico e social. Ele gera para as autoridades e organizações públicas e privadas uma obrigação de verificar se tal critério está sendo observado quando da tomada de uma decisão em relação a uma criança, e é uma garantia à criança de que seu interesse a longo prazo será levado em consideração. Deve servir como uma unidade de medida quando múltiplos interesses entram em confronto ${ }^{30}$.

No mesmo sentido, também procurando estabelecer parâmetros para uma delineação do princípio do melhor interesse, GUILHERME CALMON NOGUEIRA GAMA afirma que:

(...) por força do próprio dispositivo constitucional - representa importante mudança de eixo nas relações paterno-maternofiliais, em que o filho deixa de ser considerado objeto para ser alçado - com absoluta justiça, ainda que tardiamente - a sujeito de direito, ou seja, a pessoa humana merecedora de tutela do ordenamento jurídico, mas com absoluta prioridade comparativamente aos demais integrantes da família de que ele participa. Cuida-se, assim, de reparar um grave equívoco na história da civilização humana em que o menor era relegado a plano inferior, ao não titularizar ou exercer qualquer função na família e na sociedade, ao menos para o direito. Como pessoas humanas em processo físico e psíquico de desenvolvimento, a criança e o adolescente são portadores de condição peculiar a merecer tratamento diferenciado das outras pessoas. Tal tratamento deve ser ministrado não para diminuí-los sob o prisma jurídico, mas sim para que eles possam ser integralmente protegidos com objetivo de permitir "o desenvolvimento físico, mental, moral, espiritual e social, em condições de liberdade e dignidade", conforme a feliz redação do art. $44^{\circ}$, da Lei $8.069 / 1990$ - o Estatuto da Criança e do Adolescente ${ }^{31}$ (sem grifo no original).

Através de tal princípio, portanto, o legislador coloca a criança e o adolescente em um patamar diferenciado, não apenas reconhecendo-lhes direitos, mas atribuindo a tais direitos um caráter especial. Segundo TÂNIA DA SILVA PEREIRA,

Não se pode afastar do universo de crianças e jovens o reconhecimento de direitos da personalidade. Sendo a

30 ZERMATTEN, Jean. L'Intérêt Supérieur de l'Enfant De l'Analyse Littérale à la Portée Philosophique, p. 15. Disponível em: http://www.childsrights.org/html/documents/wr/2003-3 fr.pdf. Acesso em 11.10.2011. Tradução livre de: "L'intérêt supérieur de l'enfant est un instrument juridique qui vise à assurer le bien-être de l'enfant sur les plans physique, psychique et social. Il fonde une obligation des instances et organisations publiques ou privées d'examiner si ce critère est rempli au moment où une décision doit être prise à l'égard d'un enfant et il représente une garantie pour l'enfant que son intérêt à long terme sera pris en compte. Il doit servir d'unité de mesure lorsque plusieurs intérêts entrent en concurrence.”.

${ }^{31}$ GAMA, Guilherme Calmon Nogueira. Princípio da paternidade responsável. Revista de Direito Privado n. ${ }^{\circ} 18$, abr. 2004, p. 21-41. 
"proteção integral" um dos pilares desta especialidade dentro do Direito, a integridade física, psíquica e moral abrange a preservação da imagem, da identidade, da autonomia, dos valores, das idéias e crenças, dos espaços e objetos pessoais, bem como qualquer ameaça ou violação ${ }^{32}$.

Nesse sentido, KARYNA BATISTA SPOSATO lembra que:

No tocante aos princípios constitucionais do Direito da Criança e do Adolescente, o ponto de partida deve ser a proteção integral como linha mestra que reúne e harmoniza todos os demais princípios em um conjunto. A proteção integral deve ser concebida como a doutrina jurídica que sustenta todo atual Direito brasileiro da Criança e do Adolescente. Seu significado está em reconhecer que todos os dispositivos legais e normativos têm por finalidade proteger integralmente as crianças e os adolescentes em suas necessidades específicas, decorrentes da idade, de seu desenvolvimento e de circunstâncias materiais. A proteção integral, no entanto, deve se materializar por meio de políticas universais, políticas de proteção ou políticas socioeducativas, conforme a necessidade. Trata-se de um princípio norteador que deve obter implementação concreta na vida das crianças e dos adolescentes sem qualquer distinção ${ }^{33}$ (sem grifo no original).

Mas como aferir, na prática, a solução que melhor garanta a aplicação do princípio do melhor interesse da criança? Alguns exemplos podem ser encontrados na jurisprudência pátria.

O vício no consentimento pode anular o ato dele decorrente. Ora, se uma mãe que manifesta sua concordância em entregar seu filho à adoção o faz de maneira viciada, é de se supor que o ato decorrente de tal manifestação não subsista. Contudo, o Superior Tribunal de Justiça decidiu pela manutenção de uma adoção em que houve vício no consentimento da mãe biológica, em observância ao princípio do melhor interesse da criança, que, no caso, já estava inserida há anos na família dos adotantes ${ }^{34}$.

\footnotetext{
${ }^{32}$ PEREIRA, Tânia da Silva. Direito da criança e do adolescente - uma proposta interdisciplinar. 2. ed. rev. e atual. Rio de Janeiro: Renovar, 2008, p. 203.

${ }^{33}$ SPOSATO, Karyna Batista. A constitucionalização do direito da criança no Brasil como barreira à redução da idade penal: visões de um neoconstitucionalismo aplicado. Revista Brasileira de Ciências Criminais, no 80, set. 2009, p. 80-118.

34 “Civil. Adoção. Vício no consentimento da genitora. Boa-fé dos adotantes. Longo convívio da adotanda com os adotantes. Preponderância do melhor interesse da criança. 1. A criança adotanda é o objeto de proteção legal primário em um processo de adoção, devendo a ela ser assegurada condições básicas para o seu bem-estar e desenvolvimento sociopsicológico. 2. A constatação de vício no consentimento da genitora, com relação a entrega de sua filha para a adoção, não nulifica, por si só, a adoção já realizada, na qual é possível se constatar a boa-fé dos adotantes. 3. O alçar do direito materno, em relação à sua prole, à condição de prevalência sobre tudo e todos, dando-se a coacta manifestação da mãe-adolescente a capacidade de apagar anos de convivência familiar, estabelecida sobre os auspícios do Estado, entre o casal adotante, seus filhos naturais e a adotanda, no único lar que essa sempre teve, importa em ignorar o direito primário da infante, vista mais como objeto litigioso e menos, ou quase nada, como indivíduo, detentora, ela própria, de direitos, que, no particular, se sobrepõe aos brandidos pelas
} 
Anota-se, ainda, outro julgado do mesmo tribunal superior, que chancelou uma adoção unilateral feita pelo padrasto do menor, filho biológico de sua esposa, após a citação por edital do genitor, que não foi encontrado para responder ao processo de destituição do poder familiar. Entendeu o STJ que, caracterizado o abandono do menor pelo genitor, e havendo, no caso, uma consolidada situação de convivência e afeto entre o menor e seu padrasto, prestigiaria o melhor interesse da criança que a adoção fosse $\operatorname{admitida}^{35}$.

Por fim, em outro interessante precedente do Superior Tribunal de Justiça, o Ministério Público do Estado do Rio Grande do Sul recorreu da decisão do Tribunal de Justiça que deferiu a adoção de dois irmãos a um casal homoafetivo. Instada a se pronunciar, a Corte reconheceu que, muito embora a lei fizesse vedação indireta à adoção conjunta por pessoas do mesmo sexo, atenderia ao melhor interesse da criança permitir a adoção, uma vez que as adotantes possuíam todos os requisitos necessários para receber as crianças em seu núcleo familiar, propiciando-lhe tudo aquilo que deixariam de ter se tivessem de viver em abrigos ${ }^{36}$.

partes. 4. Apontando as circunstâncias fáticas para uma melhor qualidade de vida no lar adotivo e associando-se essas circunstâncias à convivência da adotanda, por lapso temporal significativo - 09 anos -, junto à família adotante, deve-se manter íntegro esse núcleo familiar. 5. Recurso especial provido ${ }^{34}$ (sem grifo no original) (STJ. REsp 1199465/DF. 3. ${ }^{\text {a }}$ Turma, rel. Min. Nancy Andrighi. J. 14.06.2011, DJe 21.06.2011 . v.u.).

35 “Adoção. Recurso especial. Menor que mora, desde o casamento de sua genitora com seu padrasto, em dezembro de 2000, com este. Paternidade socioafetiva. Moldura fática apurada pelas instâncias ordinárias demonstrando que o menor foi abandonado por seu pai biológico, cujo paradeiro é desconhecido. Aplicação do princípio do melhor interesse da criança. 1. As instâncias ordinárias apuraram que a genitora casou-se com o adotante e anuiu com a adoção, sendo 'patente a situação de abandono do adotando, em relação ao seu genitor', que foi citado por edital e cujo paradeiro é desconhecido. 2. No caso, diante dessa moldura fática, afigura-se desnecessária a prévia ação objetivando destituição do poder familiar paterno, pois a adoção do menor, que desde a tenra idade tem salutar relação paternal de afeto com o adotante - situação que perdura há mais de dez anos -, privilegiará o seu interesse. Precedentes do STJ. 3. Recurso especial não provido" (sem grifo no original) (STJ. REsp 1207185/MG. 4. ${ }^{a}$ Turma, rel. Min. Luis Felipe Salomão. J. 11.10.2011, DJe 22.11.2011 . v.u.). Nesse mesmo sentido, cf.: STJ. REsp 1.106.637/SP. 3. ${ }^{\text {a }}$ Turma, rel. Min. Nancy Andrighi. J. 1.6.2010, DJe 1.7.2010 . v.u. (RT 902/210).

36 "Direito Civil. Família. Adoção de menores por casal homossexual. Situação já consolidada. Estabilidade da família. Presença de fortes vínculos afetivos entre os menores e a requerente. Imprescindibilidade da prevalência dos interesses dos menores. Relatório da assistente social favorável ao pedido. Reais vantagens para os adotandos. Artigos 1..$^{\circ}$ da Lei 12.010/09 e 43 do Estatuto da Criança e do Adolescente. Deferimento da medida. (...) 12. Com o deferimento da adoção, fica preservado o direito de convívio dos filhos com a requerente no caso de separação ou falecimento de sua companheira. Asseguram-se os direitos relativos a alimentos e sucessão, viabilizando-se, ainda, a inclusão dos adotandos em convênios de saúde da requerente e no ensino básico e superior, por ela ser professora universitária. 13. A adoção, antes de mais nada, representa um ato de amor, desprendimento. Quando efetivada com o objetivo de atender aos interesses do menor, é um gesto de humanidade. Hipótese em que ainda se foi além, pretendendo-se a adoção de dois menores, irmãos biológicos, quando, segundo dados do Conselho Nacional de Justiça, que criou, em 29 de abril de 2008, o Cadastro Nacional de Adoção, 86\% das pessoas que desejavam adotar limitavam sua intenção a apenas uma criança. 14. Por qualquer ângulo que se analise a questão, seja em relação à situação fática consolidada, seja no tocante à expressa previsão legal de primazia à proteção integral das crianças, chega-se à conclusão de que, no caso dos autos, há mais do 
Pode-se entrever, da forma exemplificada, o que vem a ser a aplicação prática do princípio do melhor interesse da criança e do adolescente. Não se trata, é importante ressaltar, e conforme lembra GUSTAVO FERRAZ DE CAMPOS MÔNACO ${ }^{37}$, de atribuir-se aos princípios da proteção integral e do melhor interesse a função de conceber $a$ criança e o adolescente como seres que tudo podem, e em razão do que tudo deve ser feito. Encarar esses princípios de tal forma seria, no fim das contas, atentar contra sua finalidade, pois proteger as pessoas em estágio de desenvolvimento não significa, é claro, colocá-las em uma posição de ausência de responsabilidades e deveres. Isso seria, ultima ratio, obstruir-lhes o sadio desenvolvimento no caminho de se tornarem adultos normais, responsáveis, que construirão suas próprias famílias e, um dia, criarão seus próprios filhos.

De acordo com JOSEPH GOLDSTEIN et alli,

A lei presume que as crianças são seres incompletos durante todo o período do seu desenvolvimento. Sua incapacidade de prover suas próprias necessidades básicas, ou mesmo de manter a vida sem ajuda externa, justifica que sejam automaticamente atribuídas, no nascimento, aos seus pais biológicos ou, quando esse relacionamento não se desenvolve ou deixa de funcionar, sejam atribuídas pela justiça a substitutos dos pais. Esse grupo intimista entre os adultos e seus filhos constitui o cerne de uma família. A responsabilidade pela criança - por sua sobrevivência, seu desenvolvimento físico e mental, e por sua eventual adaptação aos padrões da sociedade - é dos adultos ou do adulto na família (...).

(...) Cada criança se desenvolve em resposta às influências ambientais a que ela é exposta. Suas habilidades emocionais, intelectuais e morais se desdobram - não num vazio, e não sem conflito - em meio às suas relações familiares. Essas habilidades, por sua vez, são refletidas em seu comportamento social ${ }^{38}$.

que reais vantagens para os adotandos, conforme preceitua o artigo 43 do ECA. Na verdade, ocorrerá verdadeiro prejuízo aos menores caso não deferida a medida. 15. Recurso especial improvido" (sem grifo no original) (STJ. REsp 889.852/RS. 4. ${ }^{\text {a }}$ Turma, rel. Min. Luis Felipe Salomão. J. 27.04.2010, DJe 10.08.2010 . v.u.).

${ }^{37}$ MÔNACO, Gustavo Ferraz de Campos. A proteção da criança no cenário internacional. Belo Horizonte: Del Rey, 2005, p. 179-183.

${ }^{38}$ GOLDSTEIN, Joseph; SOLNIT, Albert J.; GOLDSTEIN, Sonja; FREUD, Anna. The best interests of the child. New York: The Free Press, 1996, p. 8. Tradução livre de "Children are presumed in law to be incomplete beings during the whole period of their development. Their inability to provide for their own basic needs, or even to maintain life without extraneous help, justifies being automatically assigned at birth to their biological parents or, where this relationship either does not develop or fails to function, assigned by later court proceedings to parents substitutes. This intimate group of adults and their children constitutes the central core of a family. Responsibility for the child - for her survival, for her physical and mental growth, and for her eventual adaptation to community standards - this become that of the designated adults or adult in a family (...).

(...) Each child develops in response to environmental influences to which she is exposed. Her emotional, intellectual, and moral capacities unfold - not in a void, and not without conflict - within her family relationships. These capacities in turn are reflected in her social behavior". 
Percebe-se, portanto, que por suas próprias condições - físicas e psíquicas -, a criança e o adolescente são pessoas que necessitam de uma proteção especial, diferente da conferida aos adultos na medida em que tornarem-se adultos plenos demanda, justamente, esse tratamento diferenciado durante o seu estágio de desenvolvimento.

Assim, não apenas no seio familiar, mas também no âmbito da sociedade, do Estado, devem os princípios da proteção integral e do melhor interesse prevalecerem nas questões concernentes às crianças e adolescentes.

O legislador, o governo e, é claro, o Judiciário devem sempre levar tais princípios em consideração quando da sua atuação. As políticas públicas devem privilegiar tal proteção especial às crianças, através de programas, incentivos e investimentos que permitam e estimulem bem-estar dessas pessoas em desenvolvimento. O mesmo se aplica quando da elaboração de normas.

Também o magistrado, por sua vez, nunca poderá se afastar de tais princípios quando tiver de tomar qualquer decisão que diga respeito a um menor, esteja ele em situação de risco (em abandono, ou em delinquência) ou não.

No que concerne ao objeto do presente estudo, insta ressaltar que na maioria das vezes em que o Judiciário é chamado a decidir acerca de questões relativas a crianças e adolescentes que não estão em situação de risco, cuida-se de discussões familiares referentes à guarda dos filhos e ao regime de visitas, por ocasião da separação dos pais. Nessa seara o julgador deverá ter especial cuidado para decidir sempre visando atender ao superior interesse dos filhos menores, ainda que contrariamente à vontade dos pais.

\subsection{Conjugalidade e parentalidade: a convivência familiar}

A chegada dos filhos provoca importantes transformações no casal conjugal. Segundo explica a psicanalista GISELLE CÂMARA GROENINGA,

São, sobretudo, os filhos que marcam a passagem da família da esfera privada para a esfera social. Com os filhos, o casal conjugal torna-se também casal parental e às identidades de homem e mulher agregam-se as de pai e mãe, com todo o peso e expectativas individuais e sociais carreadas por estas funções. Com os filhos, modifica-se a permeabilidade da fronteira familiar, havendo maior intercâmbio com o meio social, e também controle por parte da sociedade ${ }^{40}$.

40 GROENINGA, Giselle Câmara. Guarda compartilhada - a efetividade do poder familiar. In: COLTRO, Antônio Carlos Mathias; DELGADO, Mário Luiz (coords.). Guarda Compartilhada. São Paulo: Editora Método, 2009, p. 151. 
Assim, com o nascimento dos filhos, o casal conjugal passa a ser também um casal parental - mas mais que isso: passa a ser um casal conjugal-parental. Muito embora a parentalidade não dependa da conjugalidade (um homem ou uma mulher podem ser pai ou mãe sem que haja a figura do outro genitor), ela necessariamente é influenciada por como a conjugalidade é vivida pelo casal. E a parentalidade é especialmente influenciada pela conjugalidade no momento em que esta deixa de existir.

Isso porque a separação do casal provoca transformações profundas nos membros da família, inclusive - e principalmente - nos filhos, em especial quando são pequenos e ainda não conseguem compreender bem o que a separação dos seus pais significa. Segundo expõe VERÔNICA A. DA MOTA CEZAR-FERREIRA,

(...) em função do fenômeno da interdependência, o evento da separação conjugal afetará os membros da família, em algum grau, e requererá cuidados para que a crise, se inevitável, leve a família a se adaptar à nova situação. Ela vai ter que experimentar novas pautas de interação na direção de uma mudança qualitativa em suas relações e isso lhe favorecerá rumo ao crescimento e à estabilidade emocional de seus componentes. Nesse sentido, a preocupação com a estabilidade do ex-casal deve-se ao fato de que sua evolução rumo ao crescimento e realização pessoais dependerá de atitudes amadurecidas no papel de pais. Tais atitudes, em princípio, poderão minimizar efeitos emocionais desfavoráveis nos filhos, especialmente os menores, os "interdependentes mais dependentes", mais frágeis e, por conseguinte, mais vulneráveis da família $^{41}$.

Não é difícil vislumbrar que do fim da relação que unia o casal conjugal decorrem efeitos que atingem diretamente os filhos menores, que estavam submetidos ao poder familiar do pai e da mãe enquanto casal.

Apesar de se falar em poder familiar, cuida-se, em verdade, muito mais de um múnus do que de um poder propriamente dito. Ou seja, o poder familiar é um encargo que aos pais compete, pois lhes confere muito mais deveres do que direitos em relação aos filhos. E tal encargo não lhes compete por serem um casal, mas sim por serem pais. Entrever o poder familiar dessa maneira facilita a compreensão da diferença existente entre a conjugalidade e a parentalidade.

Dessa maneira, desfeitos os laços que uniam o casal, por quaisquer motivos que sejam, finda o vínculo da conjugalidade, que os unia em casamento ou união estável. Tal

${ }^{41}$ CEZAR-FERREIRA, Verônica A. da Motta. Família, separação e mediação - uma visão psicojurídica. 2. ed. São Paulo: Ed. Método, 2007, p. 67. 
vínculo não é naturalmente perpétuo, e pode deixar de existir em decorrência da vontade daqueles que formavam o casal.

A parentalidade, contudo, é vínculo que se estabelece individualmente entre o pai, e a mãe, com seus filhos. O vínculo parental é, ao contrário da conjugalidade, perpétuo, porque decorre do simples fato da paternidade ou da maternidade. Inexiste um caráter voluntário (no sentido mesmo de voluntas, vontade) a guiar a parentalidade, como o existe na conjugalidade.

A partir da distinção desses vínculos é possível entender por que os deveres impostos mutuamente àqueles que formavam o casal conjugal - por exemplo, a fidelidade recíproca, a assistência, o respeito e a consideração mútuos, a vida em comum - cessam após o fim desse vínculo que os unia. Deixando de formar um casal, os deveres que ambos possuíam em relação um ao outro, via de regra, deixam também de existir, porque eram baseados nesse vínculo.

Contudo, tendo o casal conjugal gerado a vida, em descendentes, passa a ser, também, um casal parental, sobre o qual recaem outros deveres e obrigações, agora decorrentes de um novo vínculo: não mais aquele vínculo que os uniu, o da conjugalidade, mas o vínculo que os une, individualmente, aos seus descendentes. Tal vínculo somente se extingue pela morte, que omnia solvit. Enquanto o vínculo parental subsiste, subsistem também os deveres dele decorrentes, dos quais o poder familiar, que perdura até que o filho alcance a maioridade ou o genitor seja dele destituído, é a expressão máxima. Nesse sentido, expõe IRÈNE THÉRY que:

Quanto à noção de "casal parental", ela não é menos ambígua, sugerindo que o exercício conjunto da autoridade parental implica em acordo para tudo, como se o casal não fosse separado. Quando a dificuldade é em serem dois pais, sem serem um casal, este conceito pode ser uma fonte de intolerância em relação a quaisquer diferenças nos modos de vida, e de indevida interferência na vida do ex-cônjuge, cuja vítima final é a criança ${ }^{42}$.

Vale lembrar que uma das faces do poder familiar, que a ambos os genitores incumbe, é a guarda - que é, por óbvio, exercida conjuntamente durante a existência do vínculo conjugal (conforme, inclusive, determina o art. 1.631 do Código Civil). Extinto

${ }^{42}$ THÉRY, Irène. Couple, filiation et parenté aujourd'hui - le droit face aux mutations de la famille et de la vie privée. Paris: Éditions Odile Jacob, 1998, p. 206-207. Tradução livre de: "Quant à la notion de « couple parental ", elle n'est pas moins ambiguë, laissant croire que l'exercice commun de l'autorité parentale suppose un accord sur tout, comme si le couple n'était pas séparé. Quand toute la difficulté est de rester deux parents sans plus être un couple, cette notion peut être source d'intolérance à l'égard de toute différence dans les modes de vie, et d'immixtions injustifiées dans la vie de l'ex-époux, dont l'enfant est finalement victime". 
esse vínculo, o poder familiar se mantém inalterado, em seus direitos e deveres, salvo por uma diferença: o direito (e dever), que aos genitores detentores do poder familiar cabia, de terem os filhos em sua companhia e guarda, pode ser alterado na medida em que seja indicado para salvaguardar o melhor interesse desses filhos. Não permanecendo ambos como guardiões, através da guarda compartilhada, - muito embora o poder familiar continue a prevalecer em seus diversos aspectos - naquilo que se refere à guarda, será alterado, pois caberá a um dos genitores manter os filhos sob sua companhia e guarda, cabendo ao outro manter o convívio familiar com esses filhos através do exercício do direito de visita.

E é muito importante que após o fim da conjugalidade entre os genitores, ambos mantenham o vínculo parental com os filhos. VERÔNICA A. DA MOTA CEZARFERREIRA ressalta que:

(...) a família é uma unidade psicoafetiva e socioafetiva, na qual eventos significativos, em algum grau, atingirão seus membros e a própria estrutura familiar, e (...) a participação direta e afetiva dos pais é fundamental ao saudável desenvolvimento dos filhos. O fato de a separação ser uma crise significa que trará transformações ao grupo familiar, ainda que enfrentada da maneira mais flexível, amadurecida e harmoniosa possível ${ }^{43}$.

Nota-se, nesse esteio, a importância da relação paterno-filial para o desenvolvimento dos filhos, especialmente os de idade mais tenra. Existe uma óbvia diferença entre a situação dos menores que, por qualquer motivo que seja, são privados do convívio com os pais (por abandono, destituição do poder familiar, etc.), e as crianças e adolescentes que se vêem em meio à crise familiar instalada por ocasião da separação dos seus genitores.

IRÈNE THÉRY defende uma reflexão acerca da co-parentalidade na família pósdivórcio, chamando a atenção ao fato de que o exercício conjunto da autoridade parental pressupõe dois genitores guardiães, e à problemática de que não é incomum o sentimento de que a criança de pais separados passar a crer que possui apenas um genitor ${ }^{44}$.

É nesse sentido que se fala em direito à convivência familiar, expressamente garantido às crianças, adolescentes e jovens, com absoluta prioridade, pelo caput do art. 227 da Constituição Federal. Tal direito é garantido não apenas nos casos em que a família

\footnotetext{
${ }^{43}$ CEZAR-FERREIRA, Verônica A. da Motta. Família, separação e mediação - uma visão psicojurídica. 2. ed. São Paulo: Ed. Método, 2007, p. 87.

${ }^{44}$ THÉRY, Irène. Couple, filiation et parenté aujourd'hui - le droit face aux mutations de la famille et de la vie privée. Paris: Éditions Odile Jacob, 1998, p. 207.
} 
segue construída em meio à conjugalidade dos genitores, mas também - e, talvez, principalmente - por ocasião da ruptura da ordem conjugal.

Segundo GUSTAVO TEPEDINO, a convivência familiar

constitui-se em importante instrumento de concretização do princípio da solidariedade e da igualdade, pois consolida a convivência entre pais e filhos após o fím da conjugalidade dos pais, com o escopo de manter os vínculos afetivos e, principalmente, dar continuidade ao exercício dos deveres inerentes à autoridade parental, como determina o art. 1.632 do Código Civil. Afinal, a convivência entre os pais não há de interferir na relação de cada um deles com os filhos. Por essa razão, a convivência familiar não deve ser compreendida como prerrogativa ou direito dos pais que não exercem o múnus da guarda, mas configura direito fundamental dos filhos, previsto pelo art. 227 da Constituição da República e pelos arts. 16, V, e 19 do Estatuto da Criança e do Adolescente. Como tal, o dever de proporcionar às crianças e adolescentes a convivência familiar vincula os pais, responsáveis pelo desenvolvimento da personalidade dos filhos, sendo certo que as vicissitudes do relacionamento parental não podem interferir nesse direito fundamental ${ }^{45}$ (sem grifo no original).

Nesse diapasão, o Superior Tribunal de Justiça, em mais de uma oportunidade, já se pronunciou acerca da necessidade de se proteger a convivência familiar da criança e do adolescente como forma de garantir a observância ao princípio do melhor interesse.

Concedeu o tribunal, julgando habeas corpus, a liberdade pleiteada em favor de um paciente nigeriano, em contraponto à decisão que determinava a sua expulsão do território nacional por ter sido julgado e condenado pelo crime de tráfico internacional de drogas. $\mathrm{O}$ paciente, apesar de não ser casado com brasileira, possuía uma filha brasileira. Assim decidiu o Tribunal:

Habeas corpus. Lei 6.815/80 (Estatuto do Estrangeiro). Expulsão. Estrangeiro com prole no brasil. Fator impeditivo. Tutela do interesse das crianças. Arts. 227 e 229 da CF/88. Decreto 99.710/90 - Convenção sobre os Direitos da Criança. 1. A regra do art. 75 , II, b, da Lei $6.815 / 80$ deve ser interpretada sistematicamente, levando em consideração, especialmente, os princípios da CF/88, da Lei 8.069/90 (ECA) e das convenções internacionais recepcionadas por nosso ordenamento jurídico. 2. A proibição de expulsão de estrangeiro que tenha filho brasileiro objetiva resguardar os interesses da criança, não apenas no que se refere à assistência material, mas à sua proteção em

45 TEPEDINO, Gustavo. A tutela constitucional da criança e do adolescente: projeções civis e estatutárias. In: CHINELLATO, Silmara Juny; SIMÃO, José Fernando; FUJITA, Jorge Shiguemitsu; ZUCCHI, Maria Cristina (orgs.). Direito de Família no Novo Milênio: estudos em homenagem ao Professor Álvaro Villaça Azevedo. São Paulo: Atlas, 2010, p. 432-433. 
sentido integral, inclusive com a garantia dos direitos à identidade, à convivência familiar, à assistência pelos pais. 3 . Ordem concedida $^{46}$ (sem grifo no original).

O tolhimento do convívio familiar, mormente quando a criança possui um forte vínculo afetivo com a pessoa de quem se vê repentinamente separada, configura uma situação de potencial abalo psicológico, principalmente quando não consegue entender por que, subitamente, deixou de conviver com o genitor que antes fazia parte do seu dia-a-dia. Acerca desse tema TÂNIA DA SILVA PEREIRA aponta que:

A integridade moral, um dos fundamentos do direito ao respeito, se apresenta como projeção da personalidade e deve refletir os elementos integrantes da vida interior da pessoa desde sua infância. Como pessoas em fase de desenvolvimento, crianças e jovens devem ser preservados em sua integridade moral e psíquica, respeitados os seus sentimentos e emoções, e assistidos em suas fragilidades ${ }^{47}$ (sem grifo no original).

O Poder Judiciário vem constantemente se manifestando sobre a convivência familiar, reconhecendo a sua importância e o seu caráter fundamental no desenvolvimento sadio dos filhos menores. Em julgamento de agravo de instrumento em processo de regulamentação de visitas, decidiu o Tribunal de Justiça do Rio de Janeiro:

Direito de Família - Agravo de instrumento demanda de regulamentação de visitas movida pelo agravado - Direito fundamental da criança de manter o convívio familiar, consoante art. 227 da CRFB/88 e art. 19 do ECA - Direito inerente ao poder familiar (art. 1631 do CC/02 e art. 226 da CRFB/88), que deve ser exercido por ambos os genitores em igualdade - Estudos social e psicológico que sugeriram a ampliação do convívio com o genitor, cuja visitação foi regulamentada em finais de semanas alternados - Necessidade de se dissociar o conflito pessoal que envolve ambas as partes (excasal) do direito dos filhos a uma convivência salutar com seus pais - Decisão que se mantém. 1. Trata-se de agravo de instrumento contra decisão proferida em demanda de regulamentação de visitas movida pelo agravado em face da agravante, relativamente aos três filhos menores do ex-casal, que contam com 6, 7 e 11 anos de idade. 2. A decisão agravada regulamentou a visitação do genitor aos seus filhos, em finais de semana alternados, aos sábados, às 09h00min, entregando-os aos domingos às 20h00min. $\mathrm{Na}$ oportunidade também foi regulamentada a visitação na semana santa e foi arbitrada multa pelo descumprimento da determinação judicial pela genitora, no patamar de $\mathrm{R} \$ 2.000,00$ (dois mil reais). 3. Direito fundamental

${ }^{46}$ STJ. HC 31.449-DF. 1. ${ }^{\text {a }}$ Seção, rel. Min. Francisco Falcão, rel. p/ acórdão Min. Teori Albino Zavascki. J. 12.05.2004. m. v.

${ }^{47}$ PEREIRA, Tânia da Silva. Direito da criança e do adolescente - uma proposta interdisciplinar. 2. ed. rev. e atual. Rio de Janeiro: Renovar, 2008, p. 146. 
de toda criança e adolescente de manter o convívio com a família, principalmente com a figura dos genitores, para que tenha um desenvolvimento saudável, uma vez que se funda na necessidade de cultivar afeto e firmar vínculos familiares. 4. Convívio familiar que é uma garantia prevista na Constituição da República e no Estatuto da Criança e do Adolescente, e tem como objetivo atender ao melhor interesse do menor $(. . .)^{48}$.

O Estado, principalmente através do Poder Judiciário, vem, como se observa, atuando para efetivar a garantia que tanto o constituinte quanto o legislador ordinário deram ao direito que as crianças e adolescentes possuem à convivência familiar. TÂNIA DA SILVA PEREIRA, tratando da proibição, imposta pelo art. 1.513 do Código Civil de 2002, de interferência de qualquer pessoa, de direito público ou privado, na comunhão de vida instituída pela família, ressalta:

$\mathrm{O}$ direito à vida privada, no entanto, autoriza a interferência das forças cogentes do Estado para impedir ou fazer cessar ato contrário a esta norma. Reconhecida a convivência familiar como Direito Fundamental, (...) admite-se a intervenção do Estado e do Sistema de Justiça nas hipóteses de violação de direitos fundamentais, a exemplo das situações de maus tratos, opressão ou abuso sexual impostos pelos pais ou responsável; ${ }^{49}$.

E é muito importante ressaltar que tal direito à convivência familiar não alcança apenas as crianças que estão à espera de colocação em família substituta, por terem, por algum motivo, sido privadas da convivência com sua família natural. Outro principal destinatário da norma protetiva é o filho menor de pais separados, que, por força da própria situação em que se encontra, tenderá a sofrer uma descontinuidade na convivência com um dos genitores - no caso, o não-guardião.

Ressaltando a importância da presença dos dois genitores na vida e para o desenvolvimento dos filhos menores, ELIANE MICHELINI MARRACCINI e MARIA ANTONIETA PISANO MOTTA, expõem que:

É inquestionável a importância dos pais terem assegurada a possibilidade de desenvolvimento de seu vínculo afetivo com os filhos. Ser genitor não guardião, não significa intrinsecamente ser periférico ou secundário. $O$ que determina a boa continuidade da relação entre pais e filhos é a qualidade do contato que se estabelece, a proximidade afetiva dos momentos de encontro e

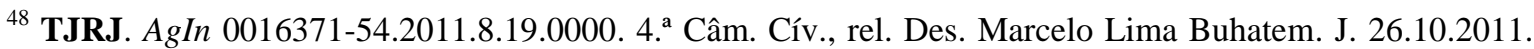
v.u.

${ }^{49}$ PEREIRA, Tânia da Silva. Direito da criança e do adolescente - uma proposta interdisciplinar. 2. ed. rev. e atual. Rio de Janeiro: Renovar, 2008, p. 202.
} 
a segurança de poder contar com esta figura de apoio. A convivência possibilita o desenvolvimento de uma relação da criança com seu progenitor assentada na realidade. Deste modo, oferece condições para que fantasias de pais imaginados como ideais ou persecutórios se desarticulem, dando lugar à relação real estabelecida ${ }^{50}$ (sem grifo no original).

Nesse sentido decidiu o Tribunal de Justiça do Rio Grande do Sul, ao julgar apelação cível em que os avós paternos de uma criança pretendiam manter a sua guarda, já que esta morava com eles desde que era bebê. Entendeu o tribunal pela inadmissibilidade do pedido, uma vez que a genitora, que pleiteava recuperar a guarda da filha, passara a possuir condições de exercer o múnus, e que seria mais contemplador dos interesses da criança que ela fosse criada e educada pela sua mãe, devendo os avós exercerem a importante função familiar que lhes compete - mas que é diversa da função parental ${ }^{51}$.

O Superior Tribunal de Justiça, em outro precedente relevante, reconheceu a legitimidade ativa do padrasto para iniciar o procedimento de destituição do poder familiar do pai biológico do filho da sua esposa, reconhecido o seu legítimo interesse em face do princípio da socioafetividade, bem como da garantia da proteção integral e do melhor interesse da criança e do adolescente. Interessante analisar as ponderações da relatora, Min. Nancy Andrighi, na ementa do acórdão:

Legitimidade ativa ad causam - Ocorrência - Poder familiar Destituição - Padrasto que postula ação, contra pai biológico, em caráter preparatório à adoção de menor - Admissibilidade Legítimo interesse que se ampara na paternidade socioafetiva Inteligência dos arts. 41, § 1. ${ }^{\circ}$, e 155 da Lei 8.069/1990. Direito civil. Família. Criança e adolescente. Adoção. Pedido preparatório de destituição do poder familiar formulado pelo padrasto em face do pai biológico. Legítimo interesse. Famílias recompostas. Melhor interesse da criança. - O procedimento para a perda do poder familiar terá início por provocação do Ministério Público ou de pessoa dotada de legítimo interesse, que se caracteriza por uma estreita relação entre o interesse pessoal do sujeito ativo e o bemestar da criança. - O pedido de adoção, formulado neste processo, funda-se no art. $41, \S 1 .^{\circ}$, do ECA (correspondente ao art. 1.626,

${ }^{50}$ MARRACCINI, Eliane Michelini; MOTTA, Maria Antonieta Pisano. Guarda dos filhos: algumas diretrizes psicanalíticas. Revista dos Tribunais, n. $^{\circ}$ 716, jun. 1995, p. 346-357.

51 “Apelação cível. Ação de tutela. Disputa entre avós paternos e genitora. Melhor interesse do infante. Embora evidenciado nos autos que o infante vem sendo muito bem atendido pelos avós paternos, com quem reside desde poucos meses de vida, tanto que pleiteiam a guarda e a tutela da criança, não pode ser acolhida a sua pretensão, já que devem ser atendidos os melhores interesses do infante, devendo a situação fática ser paulatinamente alterada para que a genitora, ao final, assuma o seu papel de mãe e guardiã na vida do menino, cabendo aos avós paternos o exercício da função parental de avós. Deram parcial provimento ao

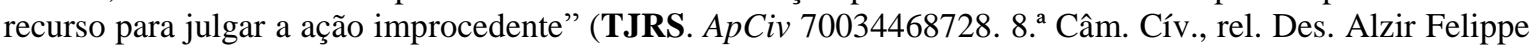
Schmitz. J. 29.4.2010. DJRS 11.5.2010. v.u. - $R T$ 898/325). No mesmo sentido, cf.: TJMG. AgIn 1.0079.07.382384-5/001. 4. ${ }^{a}$ Câm. Cív., rel. Des. Dárcio Lopardi Mendes. J. 10.04.2008. DJMG 08.05.2008. v.u. - RT 874/294. 
parágrafo único, do CC/2002), em que um dos cônjuges pretende adotar o filho do outro, o que permite ao padrasto invocar o legítimo interesse para a destituição do poder familiar do pai biológico, arvorado na convivência familiar, ligada, essencialmente, à paternidade social, ou seja, à socioafetividade, que representa, conforme ensina Tânia da Silva Pereira, um convívio de carinho e participação no desenvolvimento e formação da criança, sem a concorrência do vínculo biológico (Direito da criança e do adolescente - uma proposta interdisciplinar - 2. ed. Rio de Janeiro: Renovar, 2008. p. 735). - O alicerce, portanto, do pedido de adoção reside no estabelecimento de relação afetiva mantida entre o padrasto e a criança, em decorrência de ter formado verdadeira entidade familiar com a mulher e a adotanda, atualmente composta também por filha comum do casal. Desse arranjo familiar, sobressai o cuidado inerente aos cônjuges, em reciprocidade e em relação aos filhos, seja a prole comum, seja ela oriunda de relacionamentos anteriores de cada consorte, considerando a família como espaço para dar e receber cuidados. - Sob essa perspectiva, o cuidado, na lição de Leonardo Boff, "representa uma atitude de ocupação, preocupação, responsabilização e envolvimento com o outro; entra na natureza e na constituição do ser humano. O modo de ser cuidado revela de maneira concreta como é o ser humano. Sem cuidado ele deixa de ser humano. Se não receber cuidado desde o nascimento até a morte, o ser humano desestrutura-se, definha, perde sentido e morre. Se, ao largo da vida, não fizer com cuidado tudo o que empreender, acabará por prejudicar a si mesmo por destruir o que estiver à sua volta. Por isso o cuidado deve ser entendido na linha da essência humana" (apud Pereira, Tânia da Silva. Op. cit. p. 58). - Com fundamento na paternidade responsável, "o poder familiar é instituído no interesse dos filhos e da família, não em proveito dos genitores" e com base nessa premissa deve ser analisada sua permanência ou destituição. Citando Laurent, "o poder do pai e da mãe não é outra coisa senão proteção e direção" (Principes de Droit Civil Français, 4/350), segundo as balizas do direito de cuidado a envolver a criança e o adolescente. - Sob a tônica do legítimo interesse amparado na socioafetividade, ao padrasto é conferida legitimidade ativa e interesse de agir para postular a destituição do poder familiar do pai biológico da criança. Entretanto, todas as circunstâncias deverão ser analisadas detidamente no curso do processo, com a necessária instrução probatória e amplo contraditório, determinando-se, outrossim, a realização de estudo social ou, se possível, de perícia por equipe interprofissional, segundo estabelece o art. 162, § $1^{\circ}$, do Estatuto protetivo, sem descurar que as hipóteses autorizadoras da destituição do poder familiar - que devem estar sobejamente comprovadas - são aquelas contempladas no art. 1.638 do CC/2002 c/c art. 24 do ECA, em numerus clausus. Isto é, tão somente diante da inequívoca comprovação de uma das causas de destituição do poder familiar, em que efetivamente seja demonstrado o risco social e pessoal a que esteja sujeita a criança ou de ameaça de lesão aos seus direitos, é que o genitor poderá ter extirpado o poder familiar, em caráter preparatório à adoção, a qual tem a capacidade de cortar quaisquer vínculos existentes entre a criança e a família paterna. - $\mathbf{O}$ direito fundamental da criança e 
do adolescente de ser criado e educado no seio da sua família, preconizado no art. 19 do ECA, engloba a convivência familiar ampla, para que o menor alcance em sua plenitude um desenvolvimento sadio e completo. Atento a isso é que o juiz deverá colher os elementos para decidir consoante o melhor interesse da criança. - Diante dos complexos e intrincados arranjos familiares que se delineiam no universo jurídico ampliados pelo entrecruzar de interesses, direitos e deveres dos diversos componentes de famílias redimensionadas -, deve o juiz pautar-se, em todos os casos e circunstâncias, no princípio do melhor interesse da criança, exigindo dos pais biológicos e socioafetivos coerência de atitudes, a fim de promover maior harmonia familiar e consequente segurança às crianças introduzidas nessas inusitadas tessituras. - Por tudo isso consideradas as peculiaridades do processo -, é que deve ser concedido ao padrasto - legitimado ativamente e detentor de interesse de agir - o direito de postular em juízo a destituição do poder familiar - pressuposto lógico da medida principal de adoção por ele requerida - em face do pai biológico, em procedimento contraditório, consonante o que prevê o art. 169 do ECA. - Nada há para reformar no acórdão recorrido, porquanto a regra inserta no art. 155 do ECA foi devidamente observada, ao contemplar o padrasto como detentor de legítimo interesse para o pleito destituitório, em procedimento contraditório. Recurso especial não provido $^{52}$ (sem grifo no original).

Verifica-se, dessa forma, o caráter fundamental do direito que as crianças e os adolescentes possuem à convivência familiar, ou seja, de integrar uma família na qual se desenvolverão física, psíquica e emocionalmente. Garantir tal direito é imprescindível para que se possa atender aos princípios da proteção integral e do melhor interesse dos menores.

Estabelecer essa premissa será importante para se compreender que a efetivação do direito à convivência familiar como forma de se garantir o cumprimento dos princípios fundamentais que regem o direito protetivo do menor é especialmente colocada em xeque no momento da separação do casal conjugal-parental, momento esse em que, via de regra, os filhos menores passam a conviver diuturnamente apenas com um dos genitores, tendo restringida, portanto, a sua convivência com o outro, que não detém a guarda.

É imprescindível, conforme será tratado mais adiante, garantir que a separação do casal conjugal afete o mínimo possível a relação dos genitores com os filhos - muito embora se reconheça que tal relação sempre será afetada, decorrência lógica da própria complexidade da nova conformação familiar.

Isso porque a conjugalidade pode se desfazer simplesmente com a separação do casal, mas a parentalidade, vínculo que une o genitor ao filho, não é afetada pela desunião dos seus pais. Nenhum dos deveres que aos pais incumbiam quando formavam o casal

\footnotetext{
${ }^{52}$ STJ. REsp 1.106.637. 3. ${ }^{\text {a }}$ Turma, rel. Min. Nancy Andrighi. J. 1.6.2010. DJe 1.7.2010. v. u.
} 
conjugal deixa de existir, pelo contrário: se lhes acresce o dever de, ainda que diante de uma situação permeada por atritos e desentendimentos, se esforçar para que os interesses dos seus filhos - dentre os quais a própria convivência familiar - sejam sempre preservados. Afinal, cônjuges se divorciam; pais e filhos, não.

\subsection{O afeto como valor jurídico e o cuidado como dever objetivo}

A família é, como se apontou anteriormente, o primeiro agente socializador do ser humano $^{53}$, e o âmbito social mais restrito e privativo que uma pessoa pode conhecer. E isso se deve justamente ao fato de que, muito mais do que relações econômicas, é no seio da família que se desenvolvem as relações mais íntimas de pessoas ligadas por vínculos que ultrapassam aquilo que o Direito pode estabelecer.

Um desses vínculos, e talvez o mais importante, é o da afetividade. Por óbvio que não se busca estabelecer aqui $o$ que vem a ser tal vínculo, nem qual a sua função nas relações pessoais. Para o presente estudo importa o seu viés jurídico, pois é no âmbito da afetividade que se infiltra a alienação parental, tema central desta pesquisa.

Assim, relembrando as palavras de CAIO MÁRIO DA SILVA PEREIRA, reconhece-se que:

Os vínculos de afetividade projetam-se no campo jurídico como a essência das relações familiares. $O$ afeto constitui a diferença específica que define a entidade familiar. É o sentimento entre duas ou mais pessoas que se afeiçoam pelo convívio diuturno, em virtude de uma origem comum ou em razão de um destino comum que conjuga suas vidas tão intimamente, que as torna cônjuges quanto aos meios e aos fins de sua afeição até mesmo gerando efeitos patrimoniais, seja de patrimônio moral, seja de patrimônio econômico $^{54}$ (sem grifo no original).

Importante ressaltar que, se o vínculo da afetividade inegavelmente se estabelece entre o casal conjugal - que existe em decorrência da vontade das partes em manterem-se unidas e em estabelecerem uma comunhão de vida -, que dirá, então, na relação entre pais e filhos. E não se faz referência ao caráter biológico da filiação, como se o afeto decorresse do mero nascimento dos filhos. Não. O afeto deriva, conforme expôs Caio Mário, da relação diuturna entre pessoas que se identificam como uma entidade familiar. Não se pode conceber, portanto, hodiernamente, vínculo mais forte a manter unido um grupo de pessoas

\footnotetext{
${ }^{53}$ PEREIRA, Tânia da Silva. Da adoção. In: DIAS, Maria Berenice; PEREIRA, Rodrigo da Cunha (coords.). Direito de família e no novo Código Civil. 3. ed. Belo Horizonte: Del Rey, 2003, p. 151-176, p. 151.

${ }^{54}$ PEREIRA, Caio Mário da Silva. Instituições de Direito Civil, vol. V - Direito de Família. 17. ed. rev. e atual. por Tânia da Silva Pereira. Rio de Janeiro: Forense, 2009, p. 33.
} 
do que o afeto. E, dada a sua importância como elemento coesivo dos membros da família, natural que o Direito passasse a se preocupar em proteger tal vínculo. Também nessa linha, FLÁVIO TARTUCE ressalta que:

$\mathrm{O}$ princípio da solidariedade familiar implica respeito e consideração mútuos nos relacionamentos entre os membros da família. Como decorrência lógica desse espírito de solidariedade, surge o afeto, apontado, atualmente, como o principal fundamento das relações familiares ${ }^{55}$.

TÂNIA DA SILVA PEREIRA enfatiza que "o afeto já se incorporou como elemento identificador nas relações familiares" ${ }^{" 56}$. O princípio da afetividade, embora obviamente permeie as relações intrafamiliares, não se encontra expressamente tutelado no ordenamento jurídico pátrio. Não se faz, contudo, necessária uma tutela específica, literal, por parte do legislador. Também em decorrência dos demais princípios civilconstitucionais, pode-se visualizar a relevância jurídica do afeto em diversos dispositivos legais: a igualdade dos filhos, não apenas os biológicos, mas também os adotivos, vedando-se quaisquer designações discriminatórias (art. 227, § 6. ${ }^{\circ}$, da CF/1988, e art. 20 do ECA); o reconhecimento da união estável - situação de fato - como geradora de efeitos jurídicos semelhantes aos do casamento (art. 226, § 3. ${ }^{\circ}$, da CF/1988); a família monoparental (art. 226, § 4. ${ }^{\circ}$, da CF/1988); a ampliação do sentido de família, com o reconhecimento da "família extensa ou ampliada", que é "aquela que se estende para além da unidade pais e filhos ou da unidade do casal, formada por parentes próximos com os quais a criança ou adolescente convive e mantém vínculos de afinidade e afetividade" (art. 25, parágrafo único, do ECA); a consideração da afetividade para fins de colocação de menor em família substituta, "a fim de evitar ou minorar as consequências decorrentes da medida" (art. 28, § 3. ${ }^{\circ}$, do ECA); a possibilidade de que os divorciados, os judicialmente separados e os ex-companheiros adotem conjuntamente, quando restar "comprovada a existência de vínculos de afinidade e afetividade com aquele não detentor da guarda, que justifiquem a excepcionalidade da concessão" (art. 42, § 4..$^{\circ}$, do ECA); a punição ao agressor conviva ou tenha convivido com a mulher vítima de violência doméstica, reconhecendo-se, para a sua aplicação, qualquer relação íntima de afeto,

\footnotetext{
${ }^{55}$ TARTUCE, Flávio. Princípios constitucionais e direito de família. In: CHINELLATO, Silmara Juny; SIMÃO, José Fernando; FUJITA, Jorge Shiguemitsu; ZUCCHI, Maria Cristina (orgs.). Direito de Família no Novo Milênio: estudos em homenagem ao Professor Álvaro Villaça Azevedo. São Paulo: Atlas, 2010, p. 45 .

${ }^{56}$ PEREIRA, Tânia da Silva. Direito da criança e do adolescente - uma proposta interdisciplinar. 2. ed. rev. e atual. Rio de Janeiro: Renovar, 2008, p. 55.
} 
independentemente de coabitação (art. 5., III, da Lei 11.340/2006); são muitos os exemplos, que incluem, também, em homenagem ao princípio da afetividade, o recente reconhecimento da existência de união estável homoafetiva, através da $\mathrm{ADI} 4.277^{57}$, que

57 “1. Arguição de descumprimento de preceito fundamental (ADPF). Perda parcial de objeto. Recebimento, na parte remanescente, como ação direta de inconstitucionalidade. União homoafetiva e seu reconhecimento como instituto jurídico. Convergência de objetos entre ações de natureza abstrata. Julgamento conjunto. Encampação dos fundamentos da ADPF 132-RJ pela ADI 4.277-DF, com a finalidade de conferir 'interpretação conforme à Constituição' ao art. 1.723 do Código Civil. Atendimento das condições da ação. 2. Proibição de discriminação das pessoas em razão do sexo, seja no plano da dicotomia homem/mulher (gênero), seja no plano da orientação sexual de cada qual deles. A proibição do preconceito como capítulo do constitucionalismo fraternal. Homenagem ao pluralismo como valor sóciopolítico-cultural. Liberdade para dispor da própria sexualidade, inserida na categoria dos direitos fundamentais do indivíduo, expressão que é da autonomia de vontade. Direito à intimidade e à vida privada. Cláusula pétrea. O sexo das pessoas, salvo disposição constitucional expressa ou implícita em sentido contrário, não se presta como fator de desigualação jurídica. Proibição de preconceito, à luz do inciso IV do art. 3. ${ }^{\circ}$ da Constituição Federal, por colidir frontalmente com o objetivo constitucional de 'promover o bem de todos'. Silêncio normativo da Carta Magna a respeito do concreto uso do sexo dos indivíduos como saque da kelseniana 'norma geral negativa', segundo a qual 'o que não estiver juridicamente proibido, ou obrigado, está juridicamente permitido'. Reconhecimento do direito à preferência sexual como direta emanação do princípio da 'dignidade da pessoa humana': direito a auto-estima no mais elevado ponto da consciência do indivíduo. Direito à busca da felicidade. Salto normativo da proibição do preconceito para a proclamação do direito à liberdade sexual. O concreto uso da sexualidade faz parte da autonomia da vontade das pessoas naturais. Empírico uso da sexualidade nos planos da intimidade e da privacidade constitucionalmente tuteladas. Autonomia da vontade. Cláusula pétrea. 3. Tratamento constitucional da instituição da família. Reconhecimento de que a Constituição Federal não empresta ao substantivo 'família' nenhum significado ortodoxo ou da própria técnica jurídica. A família como categoria sócio-cultural e princípio espiritual. Direito subjetivo de constituir família. Interpretação não-reducionista. O caput do art. 226 confere à família, base da sociedade, especial proteção do Estado. Ênfase constitucional à instituição da família. Família em seu coloquial ou proverbial significado de núcleo doméstico, pouco importando se formal ou informalmente constituída, ou se integrada por casais heteroafetivos ou por pares homoafetivos. A Constituição de 1988, ao utilizar-se da expressão 'família', não limita sua formação a casais heteroafetivos nem a formalidade cartorária, celebração civil ou liturgia religiosa. Família como instituição privada que, voluntariamente constituída entre pessoas adultas, mantém com o Estado e a sociedade civil uma necessária relação tricotômica. Núcleo familiar que é o principal lócus institucional de concreção dos direitos fundamentais que a própria Constituição designa por 'intimidade e vida privada' (inciso $\mathrm{X}$ do art. 5. $^{\circ}$ ). Isonomia entre casais heteroafetivos e pares homoafetivos que somente ganha plenitude de sentido se desembocar no igual direito subjetivo à formação de uma autonomizada família. Família como figura central ou continente, de que tudo o mais é conteúdo. Imperiosidade da interpretação nãoreducionista do conceito de família como instituição que também se forma por vias distintas do casamento civil. Avanço da Constituição Federal de 1988 no plano dos costumes. Caminhada na direção do pluralismo como categoria sócio-político-cultural. Competência do Supremo Tribunal Federal para manter, interpretativamente, o Texto Magno na posse do seu fundamental atributo da coerência, o que passa pela eliminação de preconceito quanto à orientação sexual das pessoas. 4. União estável. Normação constitucional referida a homem e mulher, mas apenas para especial proteção desta última. Focado propósito constitucional de estabelecer relações jurídicas horizontais ou sem hierarquia entre as duas tipologias do gênero humano. Identidade constitucional dos conceitos de 'entidade familiar' e 'família'. A referência constitucional à dualidade básica homem/mulher, no $\S 30^{\circ}$ do seu art. 226, deve-se ao centrado intuito de não se perder a menor oportunidade para favorecer relações jurídicas horizontais ou sem hierarquia no âmbito das sociedades domésticas. Reforço normativo a um mais eficiente combate à renitência patriarcal dos costumes brasileiros. Impossibilidade de uso da letra da Constituição para ressuscitar o art. 175 da Carta de 1967/1969. Não há como fazer rolar a cabeça do art. 226 no patíbulo do seu parágrafo terceiro. Dispositivo que, ao utilizar da terminologia 'entidade familiar', não pretendeu diferenciá-la da 'família'. Inexistência de hierarquia ou diferença de qualidade jurídica entre as duas formas de constituição de um novo e autonomizado núcleo doméstico. Emprego do fraseado 'entidade familiar' como sinônimo perfeito de família. A Constituição não interdita a formação de família por pessoas do mesmo sexo. Consagração do juízo de que não se proíbe nada a ninguém senão em face de um direito ou de proteção de um legítimo interesse de outrem, ou de toda a sociedade, o que não se dá na hipótese sub judice. Inexistência do direito 
deu interpretação conforme à Constituição ao art. 1.723 do Código Civil de 2002, excluindo qualquer viés discriminatório, e garantindo às uniões estáveis homoafetivas o mesmo tratamento jurídico dispensado às uniões estáveis heteroafetivas ${ }^{58}$.

Percebe-se, portanto, que, a despeito da inexistência de uma não imprescindível regulamentação normativa do afeto, percebe-se, pela clara preocupação do constituinte e do legislador ordinário em apontar a importância de tal elemento em diversas situações, que o princípio da afetividade constitui, de fato, no concernente às relações interpessoais, um valor elementar, fundamental no ordenamento, devendo, portanto, ser levado em consideração quando da aplicação do Direito. O afeto surge como um novo olhar do legislador, da doutrina e da jurisprudência, se consolidando como um direito fundamental, como princípio norteador do direito de família ${ }^{59}$.

Diante do evidente caráter abstrato da afetividade, mormente no que se refere às relações tuteladas pelo Direito, torna-se mais fácil identificar a valorização jurídica das relações afetivas através, por exemplo, da paternidade socioafetiva, plenamente admitida pela doutrina e pela jurisprudência ${ }^{61}$. Reconhece-se, através dessa modalidade de

dos indivíduos heteroafetivos à sua não-equiparação jurídica com os indivíduos homoafetivos. Aplicabilidade do $\S 2 .^{\circ}$ do art. $5^{\circ}$ da Constituição Federal, a evidenciar que outros direitos e garantias, não expressamente listados na Constituição, emergem 'do regime e dos princípios por ela adotados', verbis: 'Os direitos e garantias expressos nesta Constituição não excluem outros decorrentes do regime e dos princípios por ela adotados, ou dos tratados internacionais em que a República Federativa do Brasil seja parte'. 5. Divergências laterais quanto à fundamentação do acórdão. Anotação de que os Ministros Ricardo Lewandowski, Gilmar Mendes e Cezar Peluso convergiram no particular entendimento da impossibilidade de ortodoxo enquadramento da união homoafetiva nas espécies de família constitucionalmente estabelecidas. Sem embargo, reconheceram a união entre parceiros do mesmo sexo como uma nova forma de entidade familiar. Matéria aberta à conformação legislativa, sem prejuízo do reconhecimento da imediata auto-aplicabilidade da Constituição. 6. Interpretação do art. 1.723 do Código Civil em conformidade com a Constituição Federal (técnica da 'interpretação conforme'). Reconhecimento da união homoafetiva como família. Procedência das ações. Ante a possibilidade de interpretação em sentido preconceituoso ou discriminatório do art. 1.723 do Código Civil, não resolúvel à luz dele próprio, faz-se necessária a utilização da técnica de 'interpretação conforme à Constituição'. Isso para excluir do dispositivo em causa qualquer significado que impeça o reconhecimento da união contínua, pública e duradoura entre pessoas do mesmo sexo como família. Reconhecimento que é de ser feito segundo as mesmas regras e com as mesmas consequências da união estável heteroafetiva" (sem grifo no original) (STF. ADI 4.277-DF. Tribunal Pleno, rel. Min. Ayres Britto. J. 05.05.2011. DJe 14.10.2011. v.u.).

58 A mencionada decisão do STF abriu caminho para diversos reconhecimentos de uniões estáveis homoafetivas, e sua imediata conversão em casamento de pessoas do mesmo sexo, mediante pedido das partes, conforme estipula a legislação aplicável à união estável. Muito embora tal tema fuja à temática central do presente estudo, trata-se de uma decisão emblemática, de consequências amplas e profundas, que, mais uma vez, levou em consideração a importância da afetividade existente entre seres humanos a quem, anteriormente, por força de lei, de forma oblíqua, não era permitido que se reconhecessem como família.

${ }^{59}$ DIAS, Maria Berenice. Manual de Direito das Famílias. 8. ed. rev. e atual. São Paulo: Ed. RT, 2011, p. 72.

61 “Ação de reconhecimento de vínculo sócio-afetivo - Pedido de regulamentação de visita - Paternidade socioafetiva - Possibilidade - Com base no princípio do melhor interesse da criança e no novo conceito eudemonista socioafetivo de família consagrado pela Constituição Federal de 1988, o direito de visita, que anteriormente era concebido apenas a quem detinha a guarda ou o poder familiar da criança, deve ser estendido a outras pessoas que com ela possuam relação de amor, carinho e afeto. Assim, considerando que o requerente conviveu com o requerido, menor de idade, durante cinco preciosos anos de 
paternidade, a existência de um direito que, via de regra, decorria apenas de filiação biológica ou adotiva. O próprio Código Civil dispõe, em seu art. 1.593, que "o parentesco é natural ou civil, conforme resulte de consanguinidade ou outra origem".

Ao admitir plenos efeitos de direito a relações afetivas entre pessoas que não possuem quaisquer vínculos biológicos, reconhece-se que, muito embora não se trate de uma situação regulamentada expressamente pelo legislador, não pode ela ficar à margem do Direito, uma vez que o afeto é o principal elemento caracterizador da relação familiar. Para manter a estabilidade da família, que possui inegável e imprescindível função social, atribui-se papel secundário à verdade biológica ${ }^{62}$. Permite-se, assim, que sejam desconsiderados os vínculos biológicos, quando houver vínculo afetivo de força tal que recomende a proteção da relação familiar ${ }^{63}$.

sua vida, como se seu pai fosse, não se pode negar o vínculo socioafetivo que os une, advindo daí a fundamentação para o pedido de visita" (sem grifo no original) (TJMG. ApCiv 1.0024.07.803449-3/001. 1. a $^{\text {a }}$ Câm. Cív., rel. Des. Eduardo Andrade. J. 2.12.2008. DJe-MG 30.1.2009. v.u. - RT 883/298). E ainda: “Apelação. Guarda provisória. Adoção sem consentimento dos pais ou destituição do pátrio poder. Cabimento ante as peculiaridades do caso concreto. Adoção sócio-afetiva. Falta de consentimento da mãe do adolescente para sua adoção. Casal que cria a criança desde seu nascimento e há mais de dezesseis anos. Peculiaridades do caso concreto que tornam imperiosa a procedência do pedido de adoção. Negaram provimento" (TJRS. ApCiv 70024389322. 8. aㅡ Câmara Cível, rel. Des. Rui Portanova. J. 16.10.2008. DJRS 16.10.2008. v.u. - RT 881/328). E também: "Negatória de paternidade. Apelação cível. Caracterização da filiação afetiva. Improcedência. Sendo a filiação um estado social, comprovada a posse do estado de filho, não se justifica a anulação de registro de nascimento. Existência de vínculo afetivo entre as partes. Contexto dos autos demonstra a existência de relação parental, e análise das demais provas é desfavorável à tese do demandante. Negado provimento. Unânime" (TJRS. ApCiv 70021847603. 7. a Câmara Cível, rel. Maria Berenice Dias. J. 19.12.2007. DJRS 10.1.2008. v.u. - RT 870/370).

${ }^{62}$ DIAS, Maria Berenice. Manual de Direito das Famílias. 8. ed. rev. e atual. São Paulo: Ed. RT, 2011, p. 372.

63 “Reconhecimento de filiação. Ação declaratória de nulidade. Inexistência de relação sanguínea entre as partes. Irrelevância diante do vínculo sócio-afetivo. Merece reforma o acórdão que, ao julgar embargos de declaração, impõe multa com amparo no art. 538, par. único, CPC se o recurso não apresenta caráter modificativo e se foi interposto com expressa finalidade de prequestionar. Inteligência da Súmula 98, STJ.

O reconhecimento de paternidade é válido se reflete a existência duradoura do vínculo sócio-afetivo entre pais e filhos. A ausência de vínculo biológico é fato que por si só não revela a falsidade da declaração de vontade consubstanciada no ato do reconhecimento. A relação sócio-afetiva é fato que não pode ser, e não é, desconhecido pelo Direito. Inexistência de nulidade do assento lançado em registro civil. O STJ vem dando prioridade ao critério biológico para o reconhecimento da filiação naquelas circunstâncias em que há dissenso familiar, onde a relação sócio-afetiva desapareceu ou nunca existiu. Não se pode impor os deveres de cuidado, de carinho e de sustento a alguém que, não sendo o pai biológico, também não deseja ser pai sócio-afetivo. A contrario sensu, se o afeto persiste de forma que pais e filhos constroem uma relação de mútuo auxílio, respeito e amparo, é acertado desconsiderar o vínculo meramente sanguíneo, para reconhecer a existência de filiação jurídica. Recurso conhecido e provido" (sem grifo no original) (STJ.

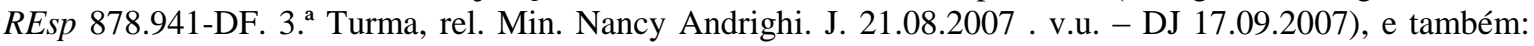
"Negatória de paternidade. Pedido de anulação de registro de nascimento. Reconhecimento espontâneo. Estado de posse de filho. Sociafetividade demonstrada. Exame de DNA que exclui a paternidade. Irrelevância. Falta de interesse de agir. Carência de ação. Extinção do feito sem julgamento do mérito" (TJSP. ApCiv 643.294.4/4. 8. ${ }^{a}$ Câm. de Direito Privado, rel. Des. Salles Rossi. Rel. p/ acórdão Des. Caetano Lagrasta. J. 30.09.2009. m. v.), e ainda: “Ação negatória de paternidade - Improcedência - Inconformismo Desacolhimento - Inexistência de vício de consentimento - Autor que reconheceu espontaneamente a paternidade, a despeito de saber que não era o pai biológico da criança - Relação entre pai e filho que não se rompe com a separação da genitora e do autor - Prevalência da relação socioafetiva sobre o vínculo biológico 
Parece indiscutível, portanto, que o afeto possui valor jurídico a ser considerado não apenas nas decisões judiciais em que ele seja relevante, mas também pelo próprio representante do povo, na atividade legislativa. Resta, contudo, a mais importante questão quando se reconhece o valor jurídico do afeto: quais as consequências e qual o alcance desse reconhecimento? Em síntese, a pergunta que de fato necessita de resposta neste ponto é: em que situações o valor jurídico do afeto é relevante?

Viu-se que o afeto possui importância no reconhecimento da paternidade que não se restringe aos vínculos biológicos. Reconhece-se, portanto, a preponderância do vínculo afetivo ao biológico nas relações familiares, o que permite chegar-se à conclusão de que os laços consanguíneos definem muito menos o círculo familiar do que os laços afetivos.

À parte das anteriormente elencadas hipóteses que versam sobre a socioafetividade, para fins de reconhecimento de paternidade não-biológica, é possível também vislumbrar o valor jurídico do afeto nas suas formas omissiva, através do que se convencionou chamar de abandono afetivo ou moral, e na forma comissiva, sendo a alienação parental uma das suas manifestações.

Esta última figura é a temática central da segunda parte desta pesquisa, consistindo, linhas gerais, na indevida e sistemática interferência, por terceiros, na relação afetiva entre uma criança ou adolescente e um dos seus genitores ${ }^{64}$. A relevância jurídica do afeto, aqui, destaca-se não pela omissão, mas pela ação, de terceira pessoa, através da interferência na relação de afetividade entre genitor e filho, prejudicando o relacionamento existente ou impedindo que ele floresça. Parece estreme de dúvidas que, em tais casos, é perfeitamente possível - aliás, imperiosa - a ação do Estado-juiz para, reconhecido o valor jurídico do afeto na relação paterno-filial, intervir, com o escopo de fazer cessar a indevida interferência.

Conforme será analisado oportunamente, existe estreita correlação entre as situações de abandono afetivo e de alienação parental, pois muitas vezes alega-se uma para defender-se da acusação da outra. Em ambos os casos existe um vilipêndio a uma relação afetiva. Restará verificar, inclusive para a apuração de responsabilidades e a eventual aplicação de sanções, se o afeto existente na figura do abandono afetivo é o mesmo, juridicamente falando, daquele presente nas hipóteses em que ocorrem a alienação parental.

- Sentença mantida - Recurso desprovido" (TJSP. ApCiv 633.989-4/8-00. 9. ${ }^{a}$ Câm. de Direito Privado, rel. Des. Grava Brasil. J. 09.05.2009. v.u.).

${ }^{64} \mathrm{Ou}$ mesmo ambos, caso a alienação seja perpetrada por terceiros que não um dos genitores, como outros parentes, ou mesmo pelo tutor ou curador, etc. 


\section{A GUARDA DOS FILHOS APÓS A SEPARAÇÃO DO CASAL ${ }^{88}$}

\subsection{Conceito: guarda e poder familiar}

De acordo com o art. 1.630 do Código Civil de 2002, “os filhos estão sujeitos ao poder familiar, enquanto menores" $"$, prevendo, ainda, o caput do art. 1.631 que "durante o casamento e a união estável, compete o poder familiar aos pais ${ }^{90}$; na falta ou impedimento de um deles, o outro exercerá com exclusividade”. Diferentemente não poderia ser. Quem senão os pais, via de regra, haveria de exercer os direitos e, principalmente, cumprir os deveres em relação aos filhos?

Regra importante acerca do poder familiar, relacionada à guarda dos filhos menores, é a constante do art. 1.632 do estatuto civil, que preconiza que "a separação judicial, o divórcio e a dissolução da união estável não alteram as relações entre pais e filhos senão quanto ao direito, que aos primeiros cabe, de terem em sua companhia os segundos".

Pode-se identificar, assim, no texto do referido dispositivo legal, o embrião do que vem a ser a guarda. Se a separação do casal não altera os direitos e os deveres entre os pais e os filhos, senão quanto ao direito que aos primeiros cabe de terem em sua companhia os segundos, quer-se dizer que o poder familiar dos pais permanece inalterado, salvo no direito que estes possuem em relação à companhia dos filhos.

Afinal de contas, dispõe o caput do art. 1.634 do Código Civil, em conjunto com seu inc. II, que compete aos pais, quanto à pessoa dos filhos menores, "tê-los em sua companhia e guarda".

Dessa maneira, cumpre observar que a guarda, tal como é tratada na lei civil, é um dos atributos do poder familiar, com ele não se confundindo. Além da guarda, o poder familiar consiste noutras prerrogativas, como a de direção da educação (art. 1.634, inc. I), de representação e assistência para os atos da vida civil (inc. IV), de exigência de respeito e obediência (inc. VII), etc. Tais prerrogativas, que não a guarda, subsistem também para o genitor não-guardião, que, contudo, possui o direito de visitar os filhos e de tê-los em sua

\footnotetext{
${ }^{88}$ Refere-se à separação em sentido amplo, abarcando não apenas a separação judicial e o divórcio, mas também o fim da união estável, e ainda relacionamentos que não se enquadram nessas duas situações, mas nos quais existia, de alguma forma, a convivência dos filhos com ambos os genitores.

${ }^{89} \mathrm{E}$, de acordo com o disposto no art. 1.590 do Código Civil, "as disposições relativas à guarda e prestação de alimentos aos filhos menores estendem-se aos maiores incapazes".

${ }^{90}$ Vale dizer que, ainda que inexista casamento ou união estável entre os pais do menor, ambos serão titulares do poder familiar, ressalvada a hipótese prevista no art. 1.633 do Código Civil, que atribui exclusivamente à mãe o poder familiar sobre o filho não reconhecido pelo pai.
} 
companhia $^{91}$, conforme determina o art. 1.589 do Código Civil. Então em que a separação do casal possui o condão de restringir o poder familiar, se os direitos e deveres entre os genitores e os filhos permanecem aparentemente os mesmos?

Importa ressaltar que o fim da conjugalidade entre os genitores, conforme visto, possui o condão de alterar o poder familiar apenas no que diz respeito à guarda. O motivo é simples: como os genitores já não dividem a mesma vida, passando a ter residências e rotinas totalmente distintas, ligados apenas pelo vínculo que possuem, cada um deles, com os filhos comuns, por óbvio que tal situação alterará o seu convívio com estes, que passarão a ter dois lares distintos: o do pai e o da mãe ${ }^{92}$.

Definir, com exatidão, o que vem a ser a guarda é tarefa difícil. Contudo, torna-se mais fácil compreender a essência do instituto se contrapusermos a guarda unilateral à guarda compartilhada. O art. 1.583, caput, do Código Civil, determina que "a guarda será unilateral ou compartilhada", e, em seus parágrafos, explicita:

$\S 1 .^{\circ}$ Compreende-se por guarda unilateral a atribuída a um só dos genitores (art. 1.584, $\S 5 .^{\circ}$ ) e, por guarda compartilhada, a responsabilização conjunta e o exercício de direitos e deveres do pai e da mãe que não vivam sob o mesmo teto, concernentes ao poder familiar dos filhos comuns.

$\S 2 .^{\circ}$ A guarda unilateral será atribuída ao genitor que revele melhores condições para exercê-la e, objetivamente, mais aptidão para propiciar aos filhos os seguintes fatores:

I - afeto nas relações com o genitor e com o grupo familiar;

II - saúde e segurança;

III - educação.

§ 3. ${ }^{\circ}$ A guarda unilateral obriga o pai ou a mãe que não a detenha a supervisionar os interesses dos filhos.

Ora, se "a guarda será unilateral ou compartilhada", é porque são institutos diferentes. Nesse passo, conforme determina o $§ 2 .^{\circ}$ do mencionado dispositivo, "a guarda unilateral será atribuída ao genitor que revele melhores condições de exercê-la". Disso pode-se inferir que, na guarda compartilhada, portanto, não existe diferença entre os

\footnotetext{
${ }^{91}$ Sobre o direito de visitas, cf. o capítulo 4, a seguir.

92 E é salutar que essa alteração exista. Especialmente quando se trata de crianças de pouca idade, é desaconselhável que passem, após a separação dos pais, a dividir o seu tempo entre duas residências, tendo que se adaptar a duas rotinas diferentes. O ideal é que possuam uma residência privilegiada, um local onde possam construir seu ponto de referência. Nesse sentido, cf. TEIXEIRA, Ana Carolina Brochado. A (des)necessidade da guarda compartilhada ante o conteúdo da autoridade parental. In: COLTRO, Antônio Carlos Mathias; DELGADO, Mário Luiz (coords.). Guarda Compartilhada. São Paulo: Editora Método, 2009, p. 36.
} 
genitores no que se refere às condições de exercer a guarda, já que tais condições são justamente o critério utilizado pelo magistrado para optar entre a guarda unilateral e a compartilhada.

$\mathrm{O} \S 3 .^{\circ}$ do referido artigo, por seu turno, obriga o pai ou a mãe que não detenha a guarda unilateral a supervisionar os interesses dos filhos. Sabe-se que, ao menos idealmente, a lei não possui palavras inúteis. Se na guarda unilateral o genitor que não a detém possui a obrigação de supervisionar os interesses dos filhos, é porque ao outro genitor - o guardião - cabe dirigir tais interesses.

Analisando-se dessa forma, torna-se mais claro que o objetivo da guarda é conferir ao genitor que a detém tal função de dirigir os interesses dos filhos, levando-se em consideração que, devido ao fato de que, com a separação do casal, os filhos passarão, invariavelmente, a conviver mais com o guardião do que com o não-guardião, aquele deverá possuir os meios necessários para garantir e efetivar os interesses dos filhos, interesses esses que o genitor não-guardião deverá fiscalizar. Isso não quer dizer que apenas o guardião terá poder de decisão sobre a vida dos filhos, mas sim que, dadas as circunstâncias em que a guarda unilateral se opera, deverá, inelutavelmente, tomar decisões diuturnas sem consultar o outro genitor.

Contudo, conforme ensina VERÔNICA A. DA MOTTA CEZAR-FERREIRA:

Costumeiramente, a guarda é entendida pelo genitor que a detém como símbolo de poder familiar absoluto. Não é raro que o outro acompanhe esse pensamento. Não raro, também, a visita é tida como de caráter social, existindo apenas para que os filhos não deixem de ter contato com o genitor que mora em outra casa. É comum a visita ser utilizada como momentos de lazer e de prazer, em que "só se vê o lado bom da vida" (...). A guarda vivida de maneira amorosa, complementada pela execução serena do regime de visitas, é que proporciona equilíbrio emocional aos filhos. A guarda existe para que a criança tenha domicílio e tenha definido o nome de quem assume os compromissos diuturnos em relação a ela. $\mathrm{O}$ genitor visitador tem a fiscalização dos cuidados inerentes à guarda e à educação (...). Em famílias separadas, para sentir-se estável, a criança precisa ter sentimento de dupla pertinência, isto é, saber que pertence inteiramente a suas duas famílias (...). A criança precisa sentir que suas duas famílias são famílias inteiras, e precisa sentir, quando em estada do não guardião, que não é hóspede, mas filho pertencente à casa daquele ${ }^{93}$.

Assim, é importante salientar que o instituto da guarda, no âmbito da separação do casal, além de servir, obviamente, para se prover a adequada e saudável criação dos filhos

${ }^{93}$ CEZAR-FERREIRA, Verônica A. da Motta. Família, separação e mediação - uma visão psicojurídica. 2. ed. São Paulo: Ed. Método, 2007, p. 118-120. 
menores, garantindo-lhes educação, saúde, segurança, etc., possui a importante função de garantir aos filhos uma adequada referência familiar, para o que contribui, também, o exercício do direito de visitas pelo genitor não-guardião. Nesse sentido, trata-se o instituto da guarda de "um complexo de deveres (e direitos) que tem por objetivo a proteção integral do filho menor" 94 .

ROBERTO JOÃO ELIAS, ao conceituar o instituto, leciona que:

Quando se fala em guarda, o que nos vem à mente é uma relação de companhia permanente, ou seja, de alguém que viva com outra pessoa na mesma residência e dela dependa, em vários aspectos, para a sua subsistência. Esta é o guardião que deve prestar ao que está sob sua guarda, assegurando-lhe tudo aquilo que é necessário para o pleno desenvolvimento de sua personalidade ${ }^{95}$.

A função da guarda é, portanto, atribuir ao genitor que a detiver o dever de exercer a autoridade parental sobre os filhos, da mesma forma a que estaria obrigado na constância do casamento ou da união estável, com a diferença que, na guarda, o fará com preponderância sobre o poder familiar do genitor não-guardião, o qual possui, contanto, o direito - e o dever - de fiscalizar o fiel cumprimento das obrigações pela guarda impostas ao guardião.

As características da guarda unilateral e da guarda compartilhada serão analisadas mais detidamente adiante. O que importa, neste ponto, é compreender o alcance do instituto da guarda, o que será necessário para compreender não apenas a sua natureza jurídica, mas também as implicações da sua atribuição a um dos genitores, ou a ambos.

\subsection{Natureza jurídica}

Conforme se salientou, a guarda, uma das expressões do poder familiar, consiste num feixe de deveres e direitos que incumbem ao genitor que a detenha, direitos e deveres esses que derivam não especificamente do instituto guarda, mas do próprio poder familiar.

Assim, a guarda, para o genitor guardião, possui a natureza de verdadeiro múnus, que consiste em cumprir todos os deveres normalmente decorrentes do poder familiar, com a diferença de que o fará, via de regra, sem ter de consultar o outro genitor em cada decisão corriqueira que for tomar na direção dos interesses dos filhos. E, além disso, cabe ao guardião o dever adicional de respeitar o direito dos filhos à convivência familiar com o

${ }^{9494}$ LEVY, Fernanda Rocha Lourenço. Guarda de filhos: os conflitos no exercício do poder familiar. São Paulo: Atlas, 2008, p. 45.

${ }^{95}$ ELIAS, Roberto João. Direitos fundamentais da criança e do adolescente. São Paulo: Saraiva, 2005, p. 47. 
outro genitor. Nesse sentido, para GUILHERME GONÇALVES STRENGER, a guarda possui o caráter de múnus, e consiste em um "poder-dever submetido a um regime jurídico-legal de modo a facultar a quem de direito prerrogativas para o exercício da proteção e amparo daquele que a lei considerar nessa condição [de filho ou menor]"96, com o que concorda GUSTAVO TEPEDINO, para quem:

A função delineada pela ordem jurídica para a autoridade parental, que justifica o espectro de poderes conferidos aos pais - muitas vezes em detrimento da isonomia na relação com os filhos e em sacrifício da privacidade e das liberdades individuais dos filhos -, só merece tutela se exercida como um múnus privado, um complexo de direitos e deveres visando ao melhor interesse dos filhos, na perspectiva de sua futura independência como pessoa (...). Tal é a dimensão em que a guarda e a autoridade parental devem ser analisadas, para que sejam efetivos instrumentos de concretização da tutela constitucional da criança e do adolescente" ${ }^{, 97}$.

Conforme transparece, é difícil a tarefa de identificar exatamente em que vem a consistir a guarda - seu conceito e sua natureza. É de se concordar, portanto, com PATRÍCIA DAHER LAZZARINI, para quem:

O que surge de novo, com a guarda, é a continuidade do exercício do poder familiar atrelada à presença física da criança, dela emanando um poder-dever a ser exercido pelo guardião para manter a criança na residência familiar e zelar pela sua educação, saúde, alimentação, promovendo todos os cuidados diários de que o filho necessita. O poder familiar não é retirado do genitor que reside em lugar diferente do que reside o menor, mas aspectos da autoridade parental, relacionados ao dia-a-dia, à presença $\mathrm{e}$, por isso mesmo, atrelados à guarda, só podem ser exercidos por quem está com mais frequência junto da criança. Do contrário, seria inviável o cotidiano se o genitor residente devesse consultar o outro para cada atitude banal relativa ao filho, como horário de aulas extracurriculares, compra de lanches na escola, $\mathrm{etc}^{98}$ (sem grifo no original).

Vale lembrar que a decisão que estabelece a guarda, bem como o regime de visitas, não faz coisa julgada material ${ }^{99}$, enquadrando-se "na modalidade de relação jurídica

\footnotetext{
${ }^{96}$ STRENGER, Guilherme Gonçalves. Guarda de filhos. São Paulo: LTr Ed., 1998, p. 32.

97 TEPEDINO, Gustavo. A tutela constitucional da criança e do adolescente: projeções civis e estatutárias. In: CHINELLATO, Silmara Juny; SIMÃO, José Fernando; FUJITA, Jorge Shiguemitsu; ZUCCHI, Maria Cristina (orgs.). Direito de Família no Novo Milênio: estudos em homenagem ao Professor Álvaro Villaça Azevedo. São Paulo: Atlas, 2010, p. 432.

${ }^{98}$ LAZZARINI, Patrícia Daher. A proteção da criança pelo exercício da guarda de menores e da visita. Dissertação de Mestrado. Faculdade de Direito da Universidade de São Paulo. São Paulo, 2009, p. 70.

${ }^{99}$ SCAFF, Fernando Campos. Considerações sobre o Poder Familiar. In: CHINELLATO, Silmara Juny; SIMÃO, José Fernando; FUJITA, Jorge Shiguemitsu; ZUCCHI, Maria Cristina (orgs.). Direito de Família
} 
continuativa, ou de trato sucessivo" 100 , podendo, a qualquer tempo, e sempre que as peculiaridades do caso exigirem, ser alteradas para garantir a proteção do melhor interesse dos filhos ${ }^{101}$.

Assim, é de se concordar que a guarda possua a natureza jurídica de um múnus privado, em que o genitor guardião permanece titular dos direitos e deveres que já lhe competiam quando exercia a guarda simultânea junto ao outro genitor, cabendo-lhe, contudo, o ônus adicional de garantir o direito dos filhos à convivência familiar com o genitor não-guardião, e de submeter-se, no que couber, ao direito de fiscalização a ser exercido por este.

\subsection{Critérios para a fixação da guarda}

A guarda dos filhos pressupõe, obviamente, que seu detentor possua condições mínimas para exercê-la. Tanto é que o art. 1.638 do Código Civil prevê a destituição do poder familiar do genitor que abusar da autoridade parental, deixando de cumprir os deveres que possui para com o filho (elencados, exemplificativamente, no art. 1.634).

Assim é que o fiel cumprimento dos deveres e obrigações decorrentes do poder familiar, do qual a guarda é uma expressão, é imposto a ambos os pais durante a guarda conjunta simultânea - ou seja, quando exercem a guarda concomitantemente, durante a constância do casamento ou da união estável -, e ao genitor guardião nas demais modalidades (na guarda unilateral, ao seu detentor; na guarda alternada, àquele que a esteja exercendo no momento; e na guarda compartilhada, a ambos).

O parâmetro principal para a atribuição da guarda é, antes de consideradas as características pessoais dos genitores, o melhor interesse dos filhos ${ }^{102}$. Tal princípio, estudado mais detalhadamente na no Capítulo 1, item 1.2, não consiste em mera

no Novo Milênio: estudos em homenagem ao Professor Álvaro Villaça Azevedo.. São Paulo: Atlas, 2010, p. 578.

${ }^{100}$ CARBONERA, Silvana Maria. Guarda de filhos na família constitucionalizada. Porto Alegre: Sergio Antonio Fabris Editor, 2000, p. 157.

${ }^{101}$ COLTRO, Antônio Carlos Mathias. A guarda (rectius, cuidado) com os filhos. In: COLTRO, Antônio C. M. (coord.). Estudos jurídicos em homenagem ao centenário de Edgard de Moura Bittencourt - A revisão do Direito de Família. Rio de Janeiro: GZ Editora, 2009, p. 23.

${ }^{102}$ Tratando do interesse do menor na atribuição da sua guarda, em Portugal, Maria Clara Sottomayor afirma que "o método empregado para determinar o interesse do menor envolve assim uma multiplicidade de factores. Com efeito, dada a impossibilidade de definir a priori um interesse que valha para todas as crianças de uma determinada idade ou sexo, impõe-se uma determinação individualizada para cada criança". Regulação do exercício do poder parental nos casos de divórcio. 2. Ed. Coimbra : Livraria Almedina, 1998, p. 37. 
"recomendação", mas sim de observância obrigatória nas decisões em que os interesses dos menores estejam sendo discutidos.

Deverá o magistrado, portanto, avaliar o caso concreto ${ }^{103}$ para identificar o genitor que possua melhores condições para o exercício da guarda, não se referindo tais condições, obviamente, apenas aos aspectos materiais, mas principalmente afetivas, morais e relacionadas à disponibilidade para cuidar dos filhos ${ }^{104}$.

É claro que os aspectos materiais são importantes, pois necessários ao sustento dos filhos. Contudo não devem servir de parâmetro principal para a atribuição da guarda, já que se o genitor não-guardião for mais abastado, incumbir-lhe-á o dever de prover as necessidades dos seus filhos, através da fixação de pensão alimentícia ${ }^{105}$.

Importam muito mais, contudo, outros aspectos, que realmente tornam um ou outro genitor mais apto a exercer a guarda. Um deles é relacionado à vinculação afetiva que os filhos possuam com os genitores. Suponha-se a situação em que os filhos, pequenos, passem muito mais tempo com a mãe porque o pai ausenta-se com frequência devido ao seu trabalho, que lhe exige viajar em demasia. Num caso semelhante a esse será natural que o vínculo afetivo dos filhos, que são ainda muito jovens, estreitem-se mais em relação à mãe, em cuja companhia estão constantemente, do que em relação ao pai, que passa muito tempo ausente. Conforme mencionam JOSEPH GOLDSTEIN et alli,

Ao contrário dos adultos, crianças não possuem uma concepção psicológica de relações decorrentes de laços sanguíneos antes de um estágio avançado no seu desenvolvimento. Para os pais biológicos, a experiência de conceber, carregar e dar à luz os prepara para que se sintam mais próximos e responsáveis em relação aos seus filhos. Tais aspectos não produzem efeito nas crianças, que são emocionalmente alheias aos eventos que levaram à sua existência. O que importa para elas é o padrão do intercâmbio diário com os adultos que delas tomam conta e que, na força de tais interações, se tornam as figuras parentais a quem elas se apegam ${ }^{106}$.

\footnotetext{
103 Se necessário, com o auxílio de equipe multidisciplinar (interprofissional), através de estudo biopsicossocial.

${ }^{104}$ Nesse sentido, o seguinte acórdão: "Direito de família - Guarda - Critérios para determinação da guarda Princípio do melhor interesse do menor. O juiz, ao apurar qual dos pais tem melhores condições para exercer a guarda, sob o ponto de vista moral, educacional e afetivo, deve analisar as circunstâncias específicas de cada caso concreto, com vistas a garantir o melhor interesse do menor" (TJMG. ApCiv. 1.0194.08.0853949/001. 4. ${ }^{a}$ Câm. Cív., rel. Des. Dárcio Lopardi Mendes. J. 26.06.2009).

${ }^{105}$ LAURIA, Flávio Guimarães. A regulamentação de visitas e o princípio do melhor interesse da criança. 2. tiragem. Rio de Janeiro: Lumen Juris, 2003, p. 79.

${ }^{106}$ GOLDSTEIN, Joseph; SOLNIT, Albert J.; GOLDSTEIN, Sonja; FREUD, Anna. The best interests of the child. New York: The Free Press, 1996, p. 9. Tradução livre de "Unlike adults, children have no psychological conception of blood-tie relationships until quite late in their development. For the biological parents, the experience of conceiving, carrying, and giving birth prepares them to feel close to and responsible for their child. These considerations carry no weight with children, who are emotionally
} 
Outro critério que deve ser levado em consideração pelo magistrado é em relação à idoneidade moral do genitor. Muito embora se trate de critério invariavelmente sujeito ao subjetivismo do juiz, analisar a moralidade da conduta dos genitores é importante no momento de se estabelecer a quem caberá a guarda dos filhos ${ }^{107}$. Por exemplo, se um genitor possui uma vida sexual desregrada e promíscua, frequenta assiduamente lugares de má-reputação, como prostíbulos, casas de jogos, etc., bem como faz uso exagerado de substâncias como álcool e outras drogas, de forma a influenciar deleteriamente o desenvolvimento dos filhos, não se lhe deve atribuir a guarda, com vistas a resguardar a sadia criação dos menores.

Não menos importante afigura-se o critério da disponibilidade dos genitores para cuidar adequadamente dos filhos. No exemplo citado, se o pai viaja constantemente a trabalho, passando pouco tempo na companhia dos filhos, é desaconselhável que seja escolhido para ser o guardião, especialmente se se tratar de crianças muito jovens, que demandam mais cuidado, atenção e acompanhamento do que, por exemplo, adolescentes de idade mais avançada, que já possuem uma independência muito maior em relação aos cuidados parentais $^{108}$.

FLÁVIO GONÇALVES LAURIA arrola algumas diretrizes básicas que podem ser seguidas pelo magistrado na avaliação para a atribuição da guarda dos filhos menores, o que deve ser feito, reitera-se, sempre em observância ao princípio do melhor interesse do menor:

unaware of the events leading to their existence. What matters to them is the pattern of day-to-day interchanges with the adults who take care of them and who, on the strength of such interactions, become the parent figures to whom they are attached". Vê-se, portanto, que o vínculo afetivo é inegavelmente mais importante que o biológico, que apesar de possuir sua importância, cede espaço à afetividade existente entre a criança e o genitor a quem será atribuída a guarda. Ambos são igualmente pais, biologicamente falando, mas, inexistindo outros óbices, a guarda deve ser atribuída àquele a quem os filhos são mais vinculados afetivamente.

${ }^{107}$ Nesse sentido, o seguinte acórdão: "Família. Alteração de guarda e alimentos. Ausência de condições pessoais da genitora em manter a guarda do filho menor, tendo em vista a sua conduta inadequada. Indícios de agressões perpetradas pela genitora. Alteração da guarda provisória confirmada na sentença, decisão que se impõe mantida. Conclusão do laudo de avaliação social favorável à guarda do infante na companhia paterna, por ser a medida que melhor atende aos seus interesses e necessidades. Conjunto probatório bem valorado. Apelação desprovida" (TJRS. ApCiv. 70036567261, 8. a Câm. Cív., rel. Des. Luiz Ari Azambuja Ramos. J. 22.07.2010).

${ }^{108}$ Nesse sentido, o seguinte acórdão: "Modificação de guarda. Estudo social efetuado em oportunidades diversas fez constar que o pai está em condições de proporcionar o necessário à prole. Faixa etária em que se encontram os menores exige disciplina. A mãe ausente durante o dia, em decorrência do labor, não tem possibilidade de acompanhar o comportamento dos filhos que exige supervisão e orientação. As partes residem próximo, o que facilita a convivência entre pais e filhos, pois as visitas são livres. Interesse dos menores deve sobressair, devendo a guarda ficar com o genitor. Apelo desprovido" (TJSP. ApCiv. 572.8084/0-00. 7. ${ }^{a}$ Câm. Direito Privado, rel. Des. Natan Zelinschi de Arruda. J. 01.10.2008). 
a) Uso habitual de drogas, alcoolismo, maus-tratos, agressividade e descontrole emocional são fatores que desaconselham a atribuição da guarda e recomendam a sua perda;

b) A guarda deve ser atribuída preferencialmente à pessoa (seja a mãe, o pai, os avós ou outros) com quem a criança se encontra, sendo maior a preferência quanto maior for o tempo de convivência; reconhecido que a criança tem dificuldade de lidar com as mudanças, estas devem ser evitadas o quanto possível;

c) A partir do momento em que as crianças se tornam aptas a expressar sua vontade (...), a guarda deverá ser decidida de acordo com a opção da criança, salvo no caso de algum motivo recomendando solução contrária revelado pelos laudos social e psicológico;

d) Quanto aos filhos em idade pouco avançada, registra-se uma preferência pela mãe; todavia, cresce a tendência de superação dessa prioridade pelo critério segundo o qual a guarda deve ser atribuída preferencialmente ao genitor que exerça as "funções maternas", seja ele o pai ou a mãe $e^{109}$.

Outros fatores podem - e devem - ser levados em consideração, tais quais a própria vontade do menor - desde que considerada de acordo com a sua capacidade de discernimento e julgamento, e sempre que não contrarie o seu próprio bem-estar ${ }^{110}$; a capacidade do genitor de dirigir a vida dos filhos, de forma a moldar-lhes a educação e o caráter; o grau de maturidade do genitor para enfrentar a situação que se lhe afigura, qual seja, a de passar a ter mais encargos e responsabilidades do que quando exercia a guarda dos filhos concomitantemente com o outro genitor; a sua capacidade de permitir e, quiçá, incentivar o convívio familiar dos filhos com o outro genitor.

Não se pretende, ainda que isso fosse possível, encerrar, aqui, a análise de todos os critérios que podem ser levados em consideração pelo magistrado no momento de decidir sobre a guarda dos filhos menores do casal que se desfaz. Procurou-se apenas traçar um panorama, elencar alguns pontos primordiais, que podem servir de norte ao juiz, que deverá, antes mesmo de escolher um dos genitores a quem atribuir a guarda (ou nenhum, caso a guarda vá ser atribuída a terceiro), verificar a possibilidade de atribuí-la a ambos. Isso porque o $\S 2 .^{\circ}$ do art. 1.584 do Código Civil elenca a guarda compartilhada como a

\footnotetext{
${ }^{109}$ LAURIA, Flávio Guimarães. A regulamentação de visitas e o princípio do melhor interesse da criança. 2. tiragem. Rio de Janeiro: Lumen Juris, 2003, p. 77-78.

${ }^{110}$ Nesse sentido, o seguinte acórdão: "Filho menor. Guarda. Interesse do menor. Manifestação de vontade. - A guarda de filho menor deve ser definida sempre levando-se em conta o bem estar do mesmo, devendo as razões de sua fixação ou alteração serem aquelas que se relacionam com o bem estar da criança, que deve prevalecer sobre qualquer outro.

- Estando as menores em idade que viabilize razoável compreensão dos fatos, assiste-lhes o direito de serem ouvidas e de terem as opiniões consideradas quanto à permanência nesta ou naquela localidade, neste ou naquele meio familiar" (TJMG. ApCiv. 1.0479.03.049654-7/001. 6. ${ }^{a}$ Câm. Cív., rel. Des. Ernane Fidélis. J. 10.05.2005).
} 
modalidade preferencial, que, se não for escolhida pelos genitores consensualmente, e se sua aplicação não for impossível, deverá ser determinada pelo magistrado, no interesse dos filhos. Assim, caso ambos os genitores apresentem condições de ser guardiães dos filhos, e caso não haja nenhum outro empecilho (como uma relação demasiadamente tempestuosa entre os genitores, a ponto de tornar impossível, na prática, a tomada de decisões e a assunção de responsabilidades conjuntas em relação aos filhos), deverá o magistrado preferir pela guarda compartilhada.

Por outro lado, caso a escolha pela guarda compartilhada seja, pelas circunstâncias do caso concreto, incompatível com o melhor interesse dos filhos, deverá o juiz escolher o genitor que melhor atender às necessidades - afetivas, emocionais e materiais - dos menores, decretando, assim, a guarda unilateral com o correspondente direito-dever de visitas atribuído ao outro genitor ${ }^{111}$.

Assim, tendo analisado os principais critérios que o magistrado deve considerar para fins de decretação da guarda dos filhos, passa-se a tratar especificamente das modalidades de guarda.

\subsection{Guarda alternada}

Inicialmente, importa mencionar que tal modalidade de guarda não foi expressamente prevista pelo legislador, que, no caput do art. 1.583 do Código Civil menciona apenas as guardas unilateral e compartilhada. Contudo, em sedes doutrinária e jurisprudencial, a guarda alternada encontra arrimo.

Nesta modalidade, conforme menciona RUBENS HIDEO ARAI,

Há uma prévia e simples divisão equânime do tempo entre os genitores. Os filhos vivem um período com um dos genitores e, em seguida, um lapso temporal idêntico com o outro, de forma que há uma alternância de habitação entre as residências dos dois genitores por parte da prole ${ }^{112^{2}}$.

Dessa forma, a alternância da guarda, que submete os filhos a passarem um período com o pai e outro com a mãe, numa constante mudança de ambiente e de hábitos, faz com

\footnotetext{
111 É útil reforçar que, conforme exposto anteriormente, um critério importante a ser utilizado pelo magistrado quando da decretação da guarda unilateral é precisamente a capacidade do genitor guardião em comprometer-se efetivamente a, se não estimular, ao menos permitir o convívio familiar dos filhos com o genitor descontínuo, até mesmo para que sejam evitadas, ao máximo, as disputas envolvendo o cumprimento do direito de visitas.

112 ARAI, Rubens Hideo. Guarda compartilhada e ação de assunção de obrigação parental. In: NANNI, Giovanni Ettore (coord.). Temas relevantes do Direito Civil Contemporâneo - reflexões sobre os cinco anos do Código Civil - Estudos em homenagem ao Professor Renan Lotufo. São Paulo: Atlas, 2008, p. 634.
} 
que se identifique, nesta modalidade de guarda, mais inconvenientes do que benefícios. Alternar a residência dos filhos entre a casa de um genitor e do outro tende a inibir o referencial que os menores possuem sobre o que é a sua residência, por conta das constantes alterações do ambiente em que vivem.

Os filhos possuem uma rotina própria, que inclui a educação, a prática de esportes, o lazer, etc. Não é raro que, em cidades de grande porte, os genitores possuam residências muito distantes uma da outra, o que atrapalharia o cotidiano escolar dos filhos, bem como suas relações de amizades com vizinhos e amigos, e até mesmo com os demais familiares.

Isso sem levar em consideração que a frequente alteração de residência importa em, a cada vez, realizar uma mudança física, ou então ter de deixar na casa do outro genitor boa parte dos seus pertences.

A guarda alternada, portanto, salvo situações excepcionalíssimas que a recomendem - como as hipóteses em que os genitores vivam em lugares muito distantes um do outro (em outros estados ou países) ${ }^{113}$-, parece ser atentatória ao melhor interesse dos filhos, que terão muita dificuldade, ou quiçá ver-se-ão impossibilitados, de "consolidar hábitos e valores necessários à formação de sua personalidade"114.

\subsection{Guarda compartilhada}

Por que o legislador, através da Lei 11.698/2008, escolheu a guarda compartilhada como a primeira a ser considerada pelo juiz, devendo ser determinada, conforme passou a dispor o $§ 2 .^{\circ}$ do art. 1.584 do Código Civil, salvo se for impossível? Aliás, o que vem a ser a guarda compartilhada?

Nas palavras de EDUARDO DE OLIVEIRA LEITE:

A noção de guarda conjunta surgiu de duas considerações bem nítidas: o desequilíbrio dos direitos parentais, que se tornou uma medida anacrônica, e de uma cultura que desloca o centro de seu interesse sobre a criança em uma sociedade de tendência igualitária ${ }^{115}$.

Assim, para facilitar a compreensão do instituto, procurar-se-á cindir a análise dos seus aspectos principais, partindo do seu conceito, passando para a sua função e, então, os

\footnotetext{
${ }^{113}$ FUJITA, Jorge Shiguemitsu. Filiação. São Paulo: Atlas, 2009, p. 89.

${ }^{114}$ ARAI, Rubens Hideo. Guarda compartilhada e ação de assunção de obrigação parental. In: NANNI, Giovanni Ettore (coord.). Temas relevantes do Direito Civil Contemporâneo - reflexões sobre os cinco anos do Código Civil - Estudos em homenagem ao Professor Renan Lotufo. São Paulo: Atlas, 2008, p. 634.

${ }^{115}$ LEITE, Eduardo de Oliveira. Famílias monoparentais - a situação jurídica de pais e mães separados e dos filhos na ruptura da vida conjugal. 2. ed. rev. atual. e ampl. São Paulo: RT, 2001, p. 262.
} 
seus efeitos, através do texto legal e, principalmente, dos posicionamentos doutrinários e jurisprudenciais sobre a matéria.

\section{Conceito}

Muito embora de maneira pouco elucidativa, buscou a lei conceituar o instituto da guarda compartilhada, no $\S 1 .^{\circ}$ do art. 1.583 do Código Civil. Segundo o mencionado dispositivo, compreende-se por guarda compartilhada "a responsabilização conjunta e $o$ exercício de direitos e deveres do pai e da mãe que não vivam sob o mesmo teto, concernentes ao poder familiar dos filhos comuns" (sem grifo no original).

Destaca-se, de início, um ponto muito importante: conforme já foi mencionado, o art. 1.632 do Código Civil é explicito ao estabelecer que, separando-se o casal, em nada se alteram as relações entre pais e filhos comuns, salvo quanto ao direito que aos primeiros cabe de terem em sua companhia os segundos. É dizer, o poder familiar dos genitores não se altera, a não ser, para o genitor não-guardião, quanto à prerrogativa de ter os filhos em sua guarda e companhia (art. 1.634, II).

Portanto pode-se considerar que a grande alteração que a guarda compartilhada trouxe ao ordenamento brasileiro no que se refere ao exercício do poder familiar sobre os filhos menores, após a separação do casal, é esse: permitir o exercício conjunto do poder familiar pelos genitores, em sua totalidade, não fazendo ressalva, como ocorre na guarda unilateral, quanto ao direito de qualquer dos genitores ter os filhos em sua companhia e guarda. Afinal, tal restrição é a única imposta ao poder familiar do genitor que, na guarda unilateral, não a detém.

Quando se fala de restrição ao poder familiar do genitor que não possui a guarda dos filhos, é importante ressaltar, não se quer tratar apenas da convivência física, ou seja, do direito do guardião de ter o filho em sua companhia. Trata-se, na verdade, de todos os deveres que a guarda impõe ao genitor que a detenha, como o de dirigir a educação dos filhos, de garantir-lhes a segurança e a proteção à saúde. Nesse sentido, a guarda compartilhada permite - aliás, impõe - o cumprimento conjunto desses deveres, o que na guarda unilateral, por sua própria natureza, seria impraticável.

Para ANA CAROLINA SILVEIRA AKEL, a guarda compartilhada é aquela em que, alterando-se as relações paterno-filiais e materno-filiais, propicia "melhor desenvolvimento psicológico e maior estabilidade para o menor, que não sentirá da mesma forma a perda de referência de seu pai ou de sua mãe", reduzindo-se, assim, "as 
dificuldades que as crianças normalmente enfrentam na adequação à nova rotina e aos novos relacionamentos após a separação dos seus genitores"116.

WALDYR GRISARD FILHO, ao tratar do tema, conceitua a guarda compartilhada:

A custódia física, ou custódia partilhada, é uma nova forma de família na qual os pais divorciados partilham a educação dos filhos em lares separados. A essência do acordo da guarda compartilhada reflete o compromisso dos pais de manter dois lares para seus filhos e de continuar a cooperar com o outro na tomada de decisões ${ }^{117}$.

Dessa mesma forma, no sentir de CHRISTIANO CASSETARI, guarda compartilhada significa

Compartilhar responsabilidades entre o pai e a mãe, e não imputála apenas a uma pessoa, haja vista que a criança e o adolescente necessitam tanto da presença materna quanto paterna. Este modelo impede que caia no esquecimento que o poder familiar, mesmo com a separação e com o divórcio de um casal, continua sendo exercido pelo pai e pela mãe ${ }^{118}$.

É possível depreender-se, pois, do texto legal e dos posicionamentos doutrinários acerca do tema, que a guarda compartilhada é a modalidade de guarda em que ambos os genitores, que já não mais formam um casal conjugal, mantêm-se, como um casal parental, integralmente investidos no poder familiar em relação aos filhos menores, cabendo-lhes, conjuntamente, tomar as decisões referentes à educação e criação dos filhos comuns.

\section{Função}

Em decorrência dos direitos fundamentais da criança e do adolescente, a autoridade parental após a separação dos genitores exerce papel essencial, por, conforme leciona GUSTAVO TEPEDINO, “tornar ambos os pais responsáveis pela educação dos filhos”.

\footnotetext{
${ }^{116}$ AKEL, Ana Carolina Silveira. Guarda compartilhada - uma nova realidade. In: COLTRO, Antônio Carlos Mathias; DELGADO, Mário Luiz (coords.). Guarda Compartilhada. São Paulo: Editora Método, 2009 , p. 43.

${ }^{117}$ GRISARD FILHO, Waldyr. Guarda compartilhada: um novo modelo de responsabilidade parental. São Paulo: Ed. Revista dos Tribunais, 2000, p. 112.

118 CASSETARI, Christiano. Guarda compartilhada: uma análise da Lei 11.698/2008. In: COLTRO, Antônio Carlos Mathias; DELGADO, Mário Luiz (coords.). Guarda Compartilhada. São Paulo: Editora Método, 2009, p. 98.
} 
Nesse sentido, a adoção da guarda compartilhada associa-se a uma "visão democrática da família, em que ambos os genitores têm igual responsabilidade" 119 .

DAVID ZIMMERMAN, para quem a guarda unilateral facilita a utilização dos filhos como instrumentos de vingança entre os genitores, afirma que

O espírito da "guarda compartilhada" vai muito além de uma simples combinação para aumentar as possibilidades de visitas (sair do papel de "pai de fim-de-semana") aos filhos. Pelo contrário, a ideologia da nova lei visa, sobretudo, reforçar uma segurança afetiva nos filhos, não só pela maior proximidade e convívio mais natural, deles com os pais, como também pela assunção direta de responsabilidades e, se possível, pelo resgate de uma menor animosidade e maior harmonia entre o casal divorciado $^{120}$.

Vislumbrando na guarda compartilhada uma salutar alternativa à guarda unilateral, GISELLE CÂMARA GROENINGA ressalta que

O estabelecimento ou a preservação das relações parentais só é possível quando há comunicação, por mínima que seja. E se faz necessário que os operadores jurídicos envidem esforços para que a comunicação se estabeleça e não se quebre. É à continuidade das relações entre o casal parental que visa a guarda compartilhada, ressaltando-se a co-responsabilidade dos pais e passando a mensagem de que estes devem se entender em função dos filhos ${ }^{121}$.

Nesse mesmo sentido é o posicionamento de FERNANDA LEVY, para quem a guarda compartilhada "tem por fim precípuo minimizar os danos sofridos pelos filhos em razão da quebra ou mesmo da inexistência prévia de relacionamento conjugal. Busca preservar os laços paterno-filiais em condições de igualdade entre os genitores" ${ }^{\prime 22}$.

\section{Efeitos}

O principal efeito decorrente da adoção da guarda compartilhada é estabelecer uma verdadeira co-responsabilidade entre os genitores pela criação dos filhos menores. Por

\footnotetext{
119 TEPEDINO, Gustavo. A tutela constitucional da criança e do adolescente: projeções civis e estatutárias. In: CHINELLATO, Silmara Juny; SIMÃO, José Fernando; FUJITA, Jorge Shiguemitsu; ZUCCHI, Maria Cristina (orgs.). Direito de Família no Novo Milênio: estudos em homenagem ao Professor Álvaro Villaça Azevedo. São Paulo: Atlas, 2010, p. 429.

${ }^{120}$ ZIMERMAN, Davi. Aspectos psicológicos da guarda compartilhada. In: COLTRO, Antônio Carlos Mathias; DELGADO, Mário Luiz (coords.). Guarda Compartilhada. São Paulo: Editora Método, 2009, p. 110.

${ }^{121}$ GROENINGA, Giselle Câmara. Guarda compartilhada - a efetividade do poder familiar. In: COLTRO, Antônio Carlos Mathias; DELGADO, Mário Luiz (coords.). Guarda Compartilhada. São Paulo: Editora Método, 2009, p. 158.

${ }^{122}$ LEVY, Fernanda Rocha Lourenço. Guarda de filhos: os conflitos no exercício do poder familiar. São Paulo: Atlas, 2008, p. 54.
} 
óbvio que tal não se dará de forma idêntica àquela que ocorreria se os genitores ainda formassem um casal, e nem se poderia esperar que assim fosse.

Contudo, as principais decisões acerca da criação dos filhos, como o colégio em que estudarão, para onde viajarão nas férias, etc., bem como questões de menor relevo, como cursos extracurriculares, prática de esportes, viagens escolares, mesada, e etc., deverão ser tomadas em conjunto pelos genitores.

É claro que algumas decisões, contudo, acabarão por se concentrar nas mãos do genitor que estiver na companhia dos filhos no momento em que precisarem ser tomadas. Tais decisões são aquelas que, mesmo na constância da união dos genitores, seriam, sem problemas, tomadas por apenas um deles, o que não implica em diminuição do poder de decisão do outro genitor sobre a criação dos filhos.

Além disso, outro efeito importante da guarda compartilhada é ausência de um regime de visitas, por desnecessário. Ora, ambos os genitores possuem a guarda dos filhos, não havendo, portanto, necessidade de se regulamentar quando e como poderão ter os filhos em sua companhia.

Com relação à residência dos menores, GISELLE CÂMARA GROENINGA lembra que, muitas vezes, a mera divisão equânime do tempo dos filhos entre os pais separados implica uma “desconsideração da necessidade da criança de referência espaçotemporal e de suas necessidades específicas de convivência com uma figura de referência, dependendo da idade e das características particulares"123.

A propósito disso, por exemplo, o Código Civil francês previa, de 1987 a 1993, em seu art. $287^{124}$, o conceito de residência habitual, a ser indicada pelo juiz em caso de exercício conjunto da autoridade parental sobre os filhos após a separação dos genitores. Essa preferência de "residência habitual” era criticada por IRÈNE THÈRY, para quem a lei civil francesa era paradoxal ao determinar a coparentalidade e, ao mesmo tempo, a necessidade de instituição de um domicílio principal:

No sentido do princípio da coparentalidade, prescreve-se o exercício comum da autoridade parental. Em sentido contrário, exige-se do juiz a fixação da residência principal

123 GROENINGA, Giselle Câmara. Guarda compartilhada - a efetividade do poder familiar. In: COLTRO, Antônio Carlos Mathias; DELGADO, Mário Luiz (coords.). Guarda Compartilhada. São Paulo: Editora Método, 2009, p. 165.

124 "Selon l'intérêt des enfants mineurs, l'autorité parentale est exercée soit en commun par les deux parents après que le juge ait recueilli leur avis, soit par l'un d'eux. En cas d'exercice en commun de l'autorité parentale, le juge indique le parent chez lequel les enfants ont leur résidence habituelle" (Código Civil Francês, art. 287, com redação dada pela Lei n ${ }^{\circ} 87-570$ de 22 de julho de 1987 - sem grifo no original). 
da criança na casa de um dos genitores, em nome do interesse do menor de não possuir senão um "lar"

Tal previsão legal foi mantida até o ano de 2002, quando o art. 287 foi revogado. A matéria passou a ser tratada no art. $373-2-9^{126}$, que, ao regular a intervenção do juiz no exercício da autoridade parental dos genitores, determina que a residência do filho menor pode ser fixada em alternância nos domicílios de cada um dos genitores, ou pode ser fixada em apenas um deles.

Concorda-se, contudo, com o argumento exposto por Groeninga. A necessidade de um referencial fixo, no caso, a residência de um dos pais, não nos parece incompatível com o compartilhamento da guarda, ao contrário do que pensava Théry - que, é preciso dizer, escreveu a citada crítica em 1998, quando a legislação francesa ainda previa a determinação, pelo juiz, de uma residência habitual para os filhos menores, regra que foi abrandada a partir de 2002.

Vale lembrar ainda que a guarda compartilhada será determinada se houver um mínimo de consenso entre os genitores sobre a criação dos filhos, e tal criação inclui a convivência familiar. Que os filhos possuam uma residência habitual não significa que possuam apenas uma residência. Não serão visitas na casa do outro genitor. Apenas terão um lugar onde sabem que sempre disporão de um espaço seu, para estudos, lazer, etc ${ }^{127}$.

É preciso, contudo, atentar para o fato de que, conforme se pode perceber, na teoria, as vantagens da guarda compartilhada são muitas, o que justificaria a sua predileção por parte do legislador, que, após a alteração feita no art. 1.583 do Código Civil pela Lei da

\footnotetext{
${ }^{125}$ THÉRY, Irène. Couple, filiation et parenté aujourd'hui - Le droit face aux mutations de la famille et de la vie privée. Paris: Odile Jacob, 1998, p. 195. Tradução livre de "Dans le sens du principe de coparentalité, on prescrit l'exercice commun de l'autorité parentale. Dans le sens inverse, on exige du juge la fixation de la residénce principale de l'enfant chez un des parents, au nom de l'intérêt de l'enfant à n'avoir qu'um 'chez soi"

126 "En application des deux articles précédents, la résidence de l'enfant peut être fixée en alternance au domicile de chacun des parents ou au domicile de l'un d'eux.

'A la demande de l'un des parents ou en cas de désaccord entre eux sur le mode de résidence de l'enfant, le juge peut ordonner à titre provisoire une résidence en alternance dont il détermine la durée. Au terme de celle-ci, le juge statue définitivement sur la résidence de l'enfant en alternance au domicile de chacun des parents ou au domicile de l'un d'eux (...)" (Código Civil Francês, art. 373-2-9, com redação dada pela Lei no 2010-769 de 9 de julho de 2010 - sem grifo no original).

${ }^{127}$ Nesse sentido, o seguinte acórdão: “Apelação cível - Ação de guarda - Critérios - Interesse do menor Guarda compartilhada. - A guarda dos filhos deve ser concedida ao genitor que revelar melhores condições de atender aos interesses dos menores. - Nada havendo que contra-indique a guarda compartilhada e que a criança resida com a mãe, deve ser mantida a sentença. O estudo social concluiu que nada há que contra-indique que a requerida exerça a guarda da filha, pois, tanto ela quanto o requerente reúnem condições para garantir bom desenvolvimento para a criança. Portanto, entendo que a residência da menor deve ser a casa de sua genitora, por nada haver que aconselhe modificá-la, tratando-se de ambiente saudável e familiar" (sem grifo no original) (TJMG. ApCiv 1.0231.05.040613-2/001. 7. a Câm. Cív., rel. Des. Heloísa Combat. J. 07.08.2007).
} 
Guarda Compartilhada, em 2008, determinou que o juiz, quando tiver a tarefa de estabelecer a guarda dos filhos, deverá optar pela guarda compartilhada, salvo se for impossível. Idealmente, essa é, de fato, a melhor solução, a que mais respeita o princípio do melhor interesse dos filhos - que permanecerão sob os cuidados e responsabilidades de ambos os pais.

Contudo, muito embora a intenção do legislador tenha sido excelente, uma vez que, idealmente, a guarda compartilhada - por sua própria natureza - previne a disputa quase sempre existente entre os genitores - por exemplo, no que se refere à regulamentação de um regime de visitas -, é preciso encarar o fato de que a realidade dos litígios envolvendo a guarda de filhos muito mais preocupante.

Ressentimentos, desprezo, mágoas, sentimento de traição e de vingança são mais do que comuns nas separações: são a regra, que, felizmente, possui muitas boas exceções. É muito corriqueiro, entretanto, que entre os genitores - ex-cônjuges ou ex-conviventes nutram entre si tais sentimentos, que não são apenas perniciosos para si mesmos, mas também, e principalmente, para os seus filhos - principalmente os menores, que não podem simplesmente se afastar do conflito entre os pais - os filhos estão, lamentavelmente, no epicentro da catástrofe criada por adultos que não conseguem resolver seus conflitos de maneira minimamente racional e civilizada, sem neles envolver a prole comum.

Inúmeros são os motivos que impossibilitam o acordo entre os genitores no que se refere à criação dos filhos. Neste momento, contudo, o importante é reconhecer tal realidade: na maioria dos casos existe conflito entre os genitores ${ }^{128}$. Em alguns desses casos, apesar da relação ser conflituosa, a determinação judicial da guarda compartilhada pode ser possível, se o conflito não for severo demais. Entretanto, em boa parte dos casos o conflito possui força tal que inviabiliza totalmente a adoção do compartilhamento de guarda, sob pena de se prejudicar ainda mais a relação entre os genitores e, o que é pior, de se colocar em risco ainda maior os filhos.

\footnotetext{
${ }^{128}$ Nesse sentido, o seguinte acórdão: "Agravo de instrumento. Separação judicial litigiosa. Guarda provisória de menor fixada em favor da mãe. Pedido de guarda compartilhada pelo pai. Casal com desinteligências. Descabimento. Fixação de visitas. Descabe o exercício da guarda compartilhada por pais que após a separação não mantém relação amistosa, tão pouco possuem o mesmo entendimento acerca da educação da filha comum. O exercício de tal modalidade de guarda, pressupõe contatos amiúde entre os pais, para discussão e acertos acerca da criação e educação do filho, se tornando inaplicável quando há conflitos entre o ex-casal. Diante da conveniência, ao menor, da intensificação paulatina das visitas ao pai, resta mantida a disposição decidida na origem, acrescida de autorização para visitas aos sábados, no horário fixado" (TJRS. AgIn 70034765057, 7. a Câm. Cív., rel. Des. André Luiz Planella Villarinho. J. 12.05.2010).
} 
Assim é que o magistrado, no momento de decidir sobre a guarda dos filhos menores, deverá atentar, com muita cautela, para tais questões, e decretar o compartilhamento da guarda sempre que for possível, conforme determinou o legislador. A guarda compartilhada é uma solução formidável, mas apenas servirá aos seus propósitos quando houver um mínimo de bom senso e de entendimento entre os genitores no que concerne à criação dos filhos menores. Contudo, se o juiz desconfiar que tal medida pode ferir o melhor interesse do menor - que, neste caso, é o de ser criado num ambiente familiar minimamente harmonioso, sem ser alvo de disputas nem causa de agressões por parte de seus genitores -, deverá optar pela guarda unilateral, confiando-a àquele genitor que demonstrar possuir melhores condições de exercê-la, e estabelecendo, em contrapartida, um amplo regime de visitas ao genitor não-guardião, com vistas a preservar o convívio familiar entre este e seus filhos.

\subsection{Guarda unilateral ou exclusiva}

Inicialmente, cumpre esclarecer que, apesar da guarda unilateral ser instituto cronologicamente anterior às guardas alternada e compartilhada, deixou-se para tratar dela por último neste capítulo por uma questão didática: o capítulo seguinte vai versar precisamente sobre o direito de visitas, que decorre justamente da guarda unilateral, em que apenas um dos genitores é o guardião dos filhos, cabendo ao outro o mencionado direito de visitá-los. Bem por esse motivo, tal modalidade de guarda configura o campo mais fértil para a violação do direito que os filhos possuem à convivência familiar com o genitor não-guardião, que, por sua vez, conforme será tratado na Parte II deste trabalho, apresenta-se como o primeiro ato da nefasta peça da Alienação Parental.

Assim, prosseguindo na conceituação do instituto, o próprio Código Civil estabeleceu-a, na primeira parte do $\S 1 .^{\circ}$ do seu art. 1.583. De acordo com o dispositivo, a guarda unilateral é “a atribuída a um só dos genitores ou a alguém que o substitua”.

Antes do advento da Lei 11.698/08 (Lei da Guarda Compartilhada), a regra era a guarda unilateral, com a correspondente regulamentação do direito de visita do genitor não-guardião aos seus filhos. Posteriormente, conforme passou a dispor o $\S 2 .^{\circ}$ do art. 1.584 do Código Civil, "quando não houver acordo entre a mãe e o pai quanto à guarda do filho, será aplicada, sempre que possível, a guarda compartilhada". Nota-se, assim, que a guarda compartilhada passou a ser a regra, passando a guarda unilateral a possuir um caráter subsidiário, aplicável "quando não houver acordo entre a mãe e o pai" - o que 
acontece com frequência. Dessa forma, diante do dissenso entre os genitores quanto à atribuição da guarda, e se as circunstâncias do caso concreto não permitirem a aplicação do seu compartilhamento, deverá o juiz atribuí-la a um dos genitores, de na modalidade unilateral ou exclusiva.

\subsubsection{Guarda unilateral consensual}

Com relação ao critério de escolha sobre a quem caberá a guarda unilateral dos filhos, dispõe a primeira parte do $\S 2 .^{\circ}$ do mencionado art. 1.583 que tal modalidade de guarda "será atribuída ao genitor que revele melhores condições para exercê-la". A aferição quanto a qual genitor possui tais melhores condições deverá ser realizada pelo magistrado, com o auxílio, se necessário, da equipe interdisciplinar, através de avaliações realizadas por assistentes sociais e psicólogos.

Além disso, reforçando o princípio da parentalidade responsável, é importante frisar que a guarda unilateral impõe ao genitor que não a detém uma obrigação: a de “supervisionar os interesses dos filhos", de acordo com o $§ 3 .^{\circ}$ do art. 1.583.

O fundamento da guarda unilateral consensual encontra-se expresso no inc. I do art. 1.584, que estipula que a guarda unilateral, bem como a compartilhada, poderá ser "requerida, por consenso, pelo pai e pela mãe, ou por qualquer deles, em ação autônoma de separação, de divórcio, de dissolução de união estável ou em medida cautelar".

A modalidade consensual de guarda unilateral pressupõe, por óbvio, a existência de uma relação minimamente amigável e civilizada entre os genitores, que, de comum acordo, decidem ser essa a solução que melhor atende ao superior interesse dos seus filhos. Tal decisão parental merece ser respeitada, especialmente porque aos pais deve caber a coordenação da vida familiar, devendo o Estado interferir apenas quando interesses indisponíveis - como os interesses dos filhos menores - puderem ser prejudicados. Via de regra, contudo, a decisão dos genitores que, consensualmente, optam pela guarda unilateral e estabelecem um regime de visitas ao genitor não-guardião, deve ser respeitada conquanto seja garantidora dos interesses dos filhos.

\subsubsection{Guarda unilateral litigiosa}

Contudo, quando não há acordo entre os genitores quanto à guarda dos filhos e à regulamentação de visitas do genitor não-guardião, cabe ao magistrado determinar, "em atenção a necessidades específicas do filho, ou em razão da distribuição de tempo necessário ao convívio deste com o pai e com a mãe", a guarda unilateral a um dos 
genitores, conforme dispõe o inc. II do art. 1.584, devendo observar, ainda, o disposto no $\S$ $2 .^{\circ}$ do art. 1.583, que determina que se atribua a guarda unilateral dos filhos "ao genitor que revele melhores condições para exercê-la".

Contudo, como forma de preservar o convívio e a manutenção dos laços afetivos entre o genitor não-guardião e os filhos, determinou o legislador, no art. 1.589 do estatuto civil, que "o pai ou a mãe, em cuja guarda não estejam os filhos, poderá visitá-los e tê-los em sua companhia, segundo acordar com o outro cônjuge, ou for fixado pelo juiz, bem como fiscalizar sua manutenção e educação". 


\section{O DIREITO DE VISITAS DO GENITOR NÃO-GUARDIÃO}

\subsection{Conceito e função do direito de visitas}

Com a separação do casal e, consequentemente, a atribuição da guarda dos filhos a um dos genitores, ao outro caberá o chamado direito de visitas, ou seja, o direito de continuar acompanhando o desenvolvimento dos filhos, de manter com eles os laços afetivos estabelecidos. A expressão direito de visitas, tal como é utilizada hodiernamente, surgiu na França, através de uma sentença da Corte de Cassação, em 1857, e significava exatamente uma visita que acontecia na casa do "visitado" 129.

Dessa forma, o direito de visitas, a ser regulamentado consensualmente pelos genitores, ou, na impossibilidade de acordo, determinado pelo juiz - que deverá estabelecer o regime que mais se adéque às particularidades do caso concreto -, constitui, por um lado, uma maneira de preservar, para o genitor descontínuo ${ }^{130}$, o contato com seus filhos, permitindo-lhe acompanhar o seu desenvolvimento. Por outro lado, com relação aos filhos, o direito de visitas é uma forma de, além de preservar os vínculos afetivos com o genitor descontínuo, manter para os filhos as figuras materna e paterna, com suas importantes funções no desenvolvimento da sua personalidade ${ }^{131}$.

Nesse sentido posicionou-se o Código Civil de 2002, que estabeleceu a previsão legal do direito de visitas no seu art. 1.589, cuja redação é clara ao determinar que "o pai ou a mãe, em cuja guarda não estejam os filhos, poderá visitá-los e tê-los em sua

\footnotetext{
${ }^{129}$ BASSET, Lidia N. Makianich. Derecho de visitas: régimen jurídico del derecho y deber de adecuada comunicación entre padres e hijos. 1. ed., $1^{\text {a }}$ reimp. Buenos Aires: Hammurabi, 1997, p. 56.

${ }^{130}$ Denominação dada ao genitor não-detentor da guarda dos filhos.

131 No direito estrangeiro o interesse do menor também é preservado no que se refere ao direito de convivência com o genitor descontínuo. No Código Civil Francês, o art. 372-2 prescreve que "(...) Chacun des père et mère doit maintenir des relations personnelles avec l'enfant et respecter les liens de celui-ci avec l'autre parent (...)"; O Código Civil argentino, por seu turno, no art. 264, § 2. , prevê que "En caso de separación de hecho, separación personal, divorcio vincular o nulidad del matrimonio, al padre o madre que ejerza legalmente la tenencia, sin perjuicio del derecho del otro de tener adecuada comunicación con el hijo y de supervisar su educación"; Em Portugal, o Código Civil, em seu art. 1905, n. 1, determina que "Nos casos de divórcio, separação judicial de pessoas e bens, declaração de nulidade ou anulação do casamento, o destino do filho, os alimentos a este devidos e forma de os prestar serão regulados por acordo dos pais, sujeito a homologação do tribunal; a homologação será recusada se o acordo não corresponder ao interesse do menor, incluindo o interesse deste em manter com aquele progenitor a quem não seja confiado uma relação de grande proximidade"; O art. 94 do Código Civil espanhol traz disposição semelhante, ao estabelecer que "El progenitor que no tenga consigo a los hijos menores o incapacitados gozará del derecho de visitarlos, comunicar con ellos y tenerlos en su compañía. El Juez determinará el tiempo, modo y lugar del ejercicio de este derecho, que podrá limitar o suspender si se dieren graves circunstancias que así lo aconsejen o se incumplieren grave o reiteradamente los deberes impuestos por la resolución judicial".
} 
companhia, segundo o que acordar com o outro cônjuge, ou for fixado pelo juiz, bem como fiscalizar sua manutenção e educação"132.

Basta uma análise superficial do mencionado texto legal para se constatar, sem qualquer possibilidade de dúvida, que ao genitor a quem não cabe a guarda dos filhos assiste o direito de continuar participando da vida da sua prole. E tal não poderia ser diferente, uma vez que, conforme visto, o fim da relação do casal não interfere na relação de cada genitor com seus filhos. Nesse sentido dispõe o art. 1.632 do Código Civil, ao determinar que "a separação judicial, o divórcio e a dissolução da união estável não alteram as relações entre pais e filhos senão quanto ao direito, que aos primeiros cabe, de terem em sua companhia os segundos".

Importante frisar, vez mais, que a ressalva que o próprio dispositivo faz, in fine, foi inserida justamente porque, logicamente, a separação dos pais importará numa alteração da convivência familiar, já que o casal parental deixará de conviver. Nem seria saudável que, por exemplo, uma criança de tenra idade ficasse muito tempo afastada da mãe, até porque o seu sadio desenvolvimento depende inclusive de um satisfatório período de aleitamento materno. Isso sem mencionar que a previsão da licença-maternidade, para a mãe de recémnascido, permite que esta possa dedicar-se exclusivamente ao filho. Assim, a restrição imposta ao genitor descontínuo quanto ao convívio com os filhos é decorrência natural do sistema de guarda unilateral, que pressupõe, entretanto, um correspondente regime de visitas, inclusive para que não se interfira na relação afetiva entre o genitor que não detém a guarda e os seus filhos.

GUSTAVO TEPEDINO ressalta a importância do direito de visitas, que possui como função primordial manter o vínculo afetivo entre os filhos e ambos os genitores. Nesse sentido, leciona que:

A convivência familiar, também denominada direito de visitas, constitui-se em importante instrumento de concretização do princípio da solidariedade e da igualdade, pois consolida a convivência entre pais e filhos após o fim da conjugalidade dos pais, com o escopo de manter os vínculos afetivos e, principalmente, dar continuidade ao exercício dos deveres inerentes à autoridade parental (...). Afinal, a convivência entre os pais não há de interferir na relação de cada um deles com os filhos ${ }^{133}$.

\footnotetext{
${ }^{132}$ Sobre a natureza do regime de visitas, se se trata de um direito ou de um dever do genitor descontínuo, vide o item 4.2, adiante.

133 TEPEDINO, Gustavo. A tutela constitucional da criança e do adolescente: projeções civis e estatutárias. In: CHINELLATO, Silmara Juny; SIMÃO, José Fernando; FUJITA, Jorge Shiguemitsu;
} 
Assim, ressalvadas as hipóteses em que o genitor não detentor da guarda é afastado do convívio com os filhos por apresentar condutas perniciosas a estes, o estabelecimento de um adequado regime de visitas, que permita a manutenção do vínculo entre o genitor descontínuo e sua prole, mantendo, dessa forma, a convivência familiar, é essencial para o sadio desenvolvimento dos filhos. Por isso, na peculiar situação em que se torna impossível a convivência simultânea dos filhos com ambos os genitores, o regime de visitas assume a função de imprescindível meio de viabilizar o exercício das funções parentais, o que auxilia no desenvolvimento da personalidade dos filhos, motivo pelo qual deve ser objeto de especial atenção dos profissionais envolvidos na resolução dessa espécie de conflito familiar ${ }^{134}$.

\subsection{Natureza jurídica do regime de visitas: direito ou dever?}

Não é objeto de discussão que, regra geral, o genitor a quem não foi deferida a guarda dos filhos possua o direito de com eles manter e desenvolver os laços familiaresafetivos ${ }^{135}$. Conforme mencionado no item anterior, o próprio art. 1.589 do Código Civil é claro ao estabelecer tal direito. Da mesma maneira, logicamente, os filhos possuem exatamente o mesmo direito, qual seja, o de não serem impedidos de conviver com o genitor descontínuo, conforme determina, inclusive, a Constituição Federal, no caput do seu art. $227^{136}$. Tal entendimento respeita, inclusive, as determinações do art. 19 do Estatuto da Criança e do Adolescente ${ }^{137}$, e do art. 9 da Convenção sobre os Direitos da Criança $^{138}$, que conferem aos filhos menores o direito à convivência familiar. Segundo MARIA BERENICE DIAS,

ZUCCHI, Maria Cristina (orgs.). Direito de Família no Novo Milênio: estudos em homenagem ao Professor Álvaro Villaça Azevedo. São Paulo: Atlas, 2010, p. 432.

${ }^{134}$ LAURIA, Flávio Guimarães. A regulamentação de visitas e o princípio do melhor interesse da criança. $2^{\mathrm{a}}$ tiragem. Rio de Janeiro: Lumen Juris, 2003, p. 60.

${ }_{135}$ Ressalvam-se os casos em que, para assegurar o efetivo cumprimento do princípio do melhor interesse do menor, faz-se necessário limitar, ou mesmo suspender, o direito de visitas do genitor descontínuo.

${ }^{136}$ Art. 227. "É dever da família, da sociedade e do Estado assegurar à criança, ao adolescente e ao jovem, com absoluta prioridade, o direito à vida, à saúde, à alimentação, à educação, ao lazer, à profissionalização, à cultura, à dignidade, ao respeito, à liberdade e à convivência familiar e comunitária, além de colocá-los a salvo de toda forma de negligência, discriminação, exploração, violência, crueldade e opressão" (sem grifo no original).

${ }^{137}$ Art. 19. "Toda criança ou adolescente tem direito a ser criado e educado no seio da sua família e, excepcionalmente, em família substituta, assegurada a convivência familiar e comunitária, em ambiente livre da presença de pessoas dependentes de substâncias entorpecentes" (sem grifo no original).

${ }^{138}$ A Convenção sobre os Direitos da Criança e do Adolescente, de 1989, que ingressou no ordenamento jurídico brasileiro através do Decreto 99.710/1990, dispõe, no Parágrafo 3. ${ }^{\circ}$ do seu art. 9. ${ }^{\circ}$, que "Os Estados Partes respeitarão o direito da criança que esteja separada de um ou de ambos os pais de manter regularmente relações pessoais e contato direto com ambos, a menos que isso seja contrário ao interesse maior da criança". 
A visitação não é somente um direito assegurado ao pai ou à mãe, é direito do próprio filho de com eles conviver, o que reforça os vínculos paterno e materno-filial. Talvez o melhor seria o uso da expressão direito de convivência, pois é isso que deve ser preservado mesmo quando pai e filho não vivem sob o mesmo teto. Não se podem olvidar suas necessidades psíquicas. Consagrado o princípio da proteção integral, em vez de regulamentar as visitas, é necessário estabelecer formas de convivência, pois não há proteção possível com a exclusão do outro genitor ${ }^{139}$ (sem grifo no original).

Ainda acerca desse tema, FLÁVIO GUIMARÃES LAURIA esclarece que

A regulamentação de visitas se apresenta, dessa forma, como o instrumento de manutenção da relação triangular ameaçada pela ruptura da vida em comum. Trata-se de instituto jurídico que tem por objetivo realizar os direitos fundamentais da criança consagrados pelo art. 227 da Constituição, sobretudo o direito à saúde, incluída a proteção à saúde mental, e à $\operatorname{dignidade}^{140}$.

Por seu turno, o art. 1.583 do atual diploma civil, em seu $\S 3 .^{\circ}$, inserido pela Lei 11.698, de 2008 (Lei da Guarda Compartilhada), dispõe que "a guarda unilateral obriga o pai ou a mãe que não a detenha a supervisionar os interesses dos filhos" (grifo nosso). Assim, se o genitor guardião possui o dever de zelar pela manutenção e pelo desenvolvimento dos filhos, ao genitor descontínuo cumpre o dever de supervisionar a sua criação. Tais obrigações decorrem do princípio da parentalidade responsável $^{141}$, insculpido no $\S 70^{\circ}$ do art. 226 da Constituição ${ }^{142}$, e aplicável, inquestionavelmente, a ambos os genitores. Nota-se, portanto, que se por um lado o planejamento familiar, e, inserida nele, a criação dos filhos, é de livre decisão dos genitores, tal prerrogativa está inegavelmente condicionada a um pressuposto, qual seja, o da parentalidade responsável. Atendendo ao princípio absoluto do melhor interesse da criança e do adolescente, pode - e deve - o Estado interferir na criação dos filhos que não se adéque ao princípio da parentalidade responsável.

\footnotetext{
${ }^{139}$ DIAS, Maria Berenice. Manual de Direito das Famílias. 8. ed. rev. e atual. São Paulo: Ed. RT, 2011, p. 447-448.

${ }^{140}$ LAURIA, Flávio Guimarães. A regulamentação de visitas e o princípio do melhor interesse da criança. $2^{\mathrm{a}}$ tiragem. Rio de Janeiro: Lumen Juris, 2003, p. 61-62.

${ }^{141}$ A expressão utilizada pelo Constituinte foi paternidade responsável, contudo, cremos que a expressão parentalidade responsável é mais compatível com o princípio da isonomia, que determina a plena igualdade entre o homem e a mulher, no que se refere a direitos e a deveres.

${ }^{142}$ Art. $226, \S 7 .^{\circ}$."Fundado nos princípios da dignidade da pessoa humana e da paternidade responsável, o planejamento familiar é livre decisão do casal, competindo ao Estado propiciar recursos educacionais e científicos para o exercício desse direito, vedada qualquer forma coercitiva por parte de instituições oficiais ou privadas" (sem grifo no original).
} 
Dessa forma, reforça-se a ideia de que o regime de visitas não é apenas um direito do genitor descontínuo. Justamente por o primordial interesse protegido ser o dos filhos, e, levando em conta que o convívio familiar com ambos os genitores é uma forma de se atender ao melhor interesse daqueles, é consectário lógico que o cumprimento do regime de visitas é um verdadeiro dever imposto aos genitores: ao que detém a guarda, que não o obstrua $^{143}$; e ao descontínuo, que o exerça ${ }^{144}$.

Nesse sentido, para a psicanalista francesa FRANÇOISE DOLTO, trata-se de "um dever absoluto do outro cônjuge visitar seu filho: ninguém pode se opor ao dever de um

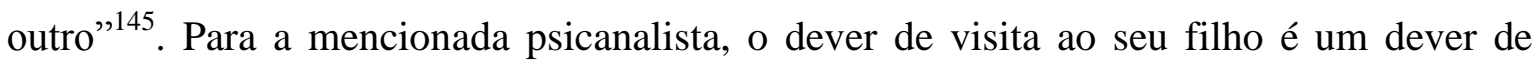
responsabilidade que cabe ao genitor descontínuo ${ }^{146}$.

O regime de visitas possui, portanto, uma natureza quádrupla: sem sombra de dúvidas configura um direito do genitor descontínuo de manter e desenvolver o relacionamento com seus filhos, e também um direito dos filhos de manterem contato com o genitor que não detém a sua guarda. Possui o regime de visitas, ainda, um caráter impositivo, para ambos os genitores: ao descontínuo, que o cumpra, fazendo-se presente na

\footnotetext{
${ }^{143}$ Vale lembrar que a cada dever não cumprido corresponde a devida sanção, que, no tocante ao direito de visitas, pode ser a destituição do poder familiar. Assim, o genitor que detém a guarda pode ser destituído por obstruir o direito dos filhos à convivência familiar com o outro genitor.

${ }^{144}$ Como aquilo que é um seu direito pode ser, para o genitor descontínuo, ao mesmo tempo, um dever? Ocorre que a visita aos filhos é um direito na medida em que oponível a todas as outras pessoas: ninguém pode impedir o genitor de estar com seus filhos, a não ser a decisão judicial devidamente fundamentada e calcada no princípio do contraditório.
}

Por outro lado, é dever do genitor descontínuo visitar os seus filhos, pois a visita é um direito destes. Dessa maneira, o genitor descontínuo pode ser destituído por não cumprir o regime de visitas, abandonando afetivamente o filho. Poder-se-ia argumentar que, se o genitor não guardião já não cumpre o regime, ser destituído do poder familiar seria uma benesse, antes de uma penalidade. Não é verdade. Isso porque pode se tratar apenas de um genitor pouco zeloso, desleixado, que não gostaria de se ver permanentemente privado do contato com os filhos, mas cuja desídia e pouco caso merecem uma reprimenda.

$\mathrm{E}$, de qualquer forma, a destituição do poder familiar não importa em desobrigação alimentar, à qual o genitor destituído continuará vinculado. A perda do poder familiar por meio de decisão judicial (art. 1.635, $\mathrm{V}$, c/c art. 1.638, ambos do CC/2002) não possui o condão de extinguir o vínculo biológico entre o menor e o genitor que, no exemplo em comento, praticou o abandono afetivo.

Diferentemente nem poderia ser, uma vez que a perda do poder familiar, ao contrário da sua extinção, constitui verdadeira penalidade imposta àquele que descumpriu a obrigação de exercer a parentalidade de forma responsável. Ora, se o genitor já abandonou afetivamente o filho, como se poderia admitir que a sua destituição do poder familiar sobre tal filho lhe produziria qualquer desconforto? Seria, de fato, uma benesse. Justamente por tal situação ser, além de injusta, ilógica, é que se defende a ideia de que a perda do poder familiar, através da destituição, não faz cessar a obrigação alimentar entre o genitor e o filho.

Insta dizer, ainda, que, decorrendo desdobramentos psicológicos danosos aos filhos, o genitor que lhes deu causa poderá ser compelido a arcar com o tratamento profissional adequado que vise reverter os danos causados.

${ }^{145}$ DOLTO, Françoise. Quando os pais se separam. Tradução de Vera Ribeiro. Rio de Janeiro: Jorge Zahar Editor, 1989, p. 51. Além disso, frise-se que o art. 229 da Constituição Federal dispõe que os pais - e não apenas o genitor-guardião - "têm o dever de assistir, criar e educar os filhos menores (...)", o que reforça a ideia de que o convívio parental, através do regime de visitas, não é apenas um direito do genitor descontínuo, mas um seu dever, e, portanto, não pode, via de regra, ser obstruído.

${ }^{146}$ DOLTO, Françoise. Quando os pais se separam. Tradução de Vera Ribeiro. Rio de Janeiro: Jorge Zahar Editor, 1989, p. 60. 
vida dos filhos ${ }^{147}$, e ao genitor guardião, que se abstenha de interferir indevidamente naquela relação.

Parece, portanto, equivocado o posicionamento de AMANDA ZOË SLHESSARENKO quando afirma que "o sujeito passivo do direito de visita será o menor", e que "o sujeito ativo será o detentor da autoridade parental (pai ou mãe), que não tenha a guarda do menor" ${ }^{\prime 48}$. Não resta dúvida de que o direito de visitas é, primeiramente, um direito do filho e um dever dos pais, e apenas em segundo plano um direito do genitor descontínuo.

Antes mesmo da Constituição Federal de 1988 ser promulgada, estabelecendo as bases da despatrimonialização do Direito de Família, e, dessa forma, permitindo uma maior humanização das decisões judiciais atinentes à família, SIDNEI BENETI sustentava que:

Os direitos de visitas aos filhos sob a guarda do outro genitor, de tê-los na companhia e de fiscalizar-lhes a manutenção e educação, (...) são a contrapartida da ausência da guarda, preenchem, como possível, o claro nas relações entre pais e filhos provocados pela falta do trato diário na convivência na casa comum. Típicas parcelas do pátrio poder, esses direitos haurem neste suas características, a começar por serem não só direitos, mas também deveres do genitor sem a guarda (...). Visitas, companhia e fiscalização das condições de formação são necessárias aos filhos, tanto quanto o é o exercício da guarda. Nessa ordem de idéias, o direito de visitas é irrenunciável e não pode ser suprimido, conquanto seu exercício possa sofrer limitações ou, à inviabilidade absoluta, recusado (...). Deve-se preservar, por todas as formas, a realização das visitas, em atenção à necessidade de contato com o genitor despojado da guarda ${ }^{149}$ (sem grifo no original).

É de se considerar, em conformidade com o exposto acima, que o chamado direito de visitas, ou seja, a manutenção do convívio entre o genitor que não detém a guarda e seus

\footnotetext{
${ }^{147}$ Não se trata de obrigar o genitor descontínuo a amar o filho. Contudo, a sua condição de pai (ou mãe) demanda o exercício de uma paternidade (ou maternidade) responsável, que vele pelo bem-estar e pelo sadio desenvolvimento dos seus filhos. Ser pai, ou mãe, não é apenas trazer o filho no mundo, e nem mesmo é apenas prover-lhe com o indispensável para o seu sustento e educação. É claro que não é possível constranger o genitor a conviver com o seu filho, a dar-lhe atenção e afeto - e nem isso seria minimamente recomendável. Contudo, sendo o caso de o genitor descontínuo não querer tal convívio, deverá responsabilizar-se por eventuais danos psicológicos que venham a ser sofridos pelos seus filhos em decorrência da sua ausência injustificada, através não de indenização por abandono afetivo, mas do custeio de, sendo necessário, tratamento psicológico ao filho abandonado.

${ }_{148}$ SLHESSARENKO, Amanda Zoë. Uma visão sobre guarda de menor e direito de visita na sociedade contemporânea. Dissertação de Mestrado. Faculdade de Direito da Universidade de São Paulo. São Paulo, 2001, p. 84.

${ }^{149}$ BENETI, Sidnei Agostinho. Os direitos de guarda, visita e fiscalização dos filhos ante a separação dos pais. Revista dos Tribunais, $\mathrm{n}^{\circ}$ 622, 1987, p. 37-45.
} 
filhos, vai muito além da concepção que, durante muitos anos, vigorou nas regulamentações dos regimes de visitas.

É inegável que se trata de um direito do genitor descontínuo o de visitar os filhos, e de estabelecer com eles uma convivência que permita a manutenção dos vínculos familiares. Contudo, dada a primazia dos interesses dos menores, que também possuem o direito à convivência familiar, assiste-lhes o direito de manter contato com o genitor descontínuo. Assim, o que até algum tempo atrás era mero direito do genitor passa a ser um seu dever. Nesse sentido posicionou-se GISELDA MARIA FERNANDES NOVAES HIRONAKA, ao identificar como um dever dos pais produzir a convivência familiar, "de modo a buscar cumprir a tarefa relativa ao desenvolvimento de suas crias, que é, provavelmente, a mais valiosa de todas as tarefas incumbidas à raça humana"150.

Como o direito dos filhos é protegido com preferência sobre o direito dos pais, e como a convivência familiar é um direito indisponível e imprescritível que aos filhos assiste, parece lógico afirmar que tal direito dos filhos passa a ser um dever aos pais imposto.

O regime de visitas, portanto, configura um verdadeiro amálgama de direitos e de deveres, estabelecidos, sempre, visando atender, principalmente, o que for do melhor interesse dos filhos menores, dada sua especial condição de pessoa em desenvolvimento, a demandar proteção integral por parte da família, da sociedade e, é claro, do Estado.

\subsection{Formas e critérios para a fixação do regime de visitas}

Ressaltou-se, no item anterior, a natureza de direito-dever do regime de visitas, como forma de garantir a primazia do melhor interesse da criança e do adolescente, que possuem o direito à convivência familiar com ambos os genitores.

Dessa forma, reconhecida a importância do estabelecimento de um regime de visitas que propicie tal convivência entre o genitor que não detém a guarda e seus filhos, mister perquirir acerca das formas que tal regime pode adotar, bem como os critérios que devem ser levados em consideração não apenas pelos pais, mas principalmente pelo

\footnotetext{
${ }^{150}$ HIRONAKA, Giselda Maria Fernandes Novaes. Os contornos jurídicos da responsabilidade afetiva na relação entre pais e filhos: além da obrigação legal de caráter material. Disponível em: <http://www.intelligentiajuridica.com/v3/artigo_visualizar.php?id=951\&pagina=artigo_busca_form.php> Acesso em: 19 de outubro de 2010.
} 
magistrado - se necessário com o auxílio de equipe interprofissional ${ }^{151}$, no momento de se estabelecer o regime de visitas.

Ao tratar desse tema, FLÁVIO GUIMARÃES LAURIA pondera que:

deve-se ter em mente, portanto, que estamos lidando com uma situação de elevado teor de conflituidade potencial, e muitas vezes efetiva. $\mathrm{O}$ regime de visitas deve ser, por conseguinte, sempre o mais detalhado possível, sendo esta recomendação mais indicada quanto menor for a idade da criança (...). O passar do tempo e o amadurecimento e desenvolvimento do filho igualmente vão proporcionar adaptações naturais ao regime (...). O que é importante, todavia, é que a regulamentação exista e esteja pronta para entrar em ação, na eventualidade de degradação do relacionamento entre os pais ${ }^{152}$.

Trata-se de tarefa impossível estabelecer um rol taxativo de critérios a serem considerados pelo juiz na fixação da guarda. Tal seria, na verdade, contraproducente, pois retiraria do magistrado a necessária autonomia e discricionariedade de que as inúmeras variáveis passíveis de serem observadas em cada caso concreto necessitam para serem solucionadas. É possível, contudo, "alinhar algumas circunstâncias que não sofrem contestação do senso comum, como por exemplo o envolvimento com drogas, maus-tratos, com ou sem violência, alcoolismo, rebaixamento mental grave com perda de discernimento, etc" $" 153$.

4.3.1. Regime fixado em comum acordo entre os genitores e regime determinado pelo magistrado

Quanto ao estabelecimento do regime de visitas, ele pode derivar de comum acordo entre os genitores ou, na impossibilidade de composição, ser determinado pelo Judiciário. Desnecessário dizer que o regime estabelecido de comum acordo é o mais recomendado,

\footnotetext{
${ }^{151} \mathrm{O}$ apoio da equipe interprofissional (ou multidisciplinar) das disputas envolvendo a guarda de filhos, bem como a regulamentação do direito de visitas, é essencial para auxiliar o magistrado a tomar a decisão mais acertada, preservando, dessa forma, o interesse do menor. Muitas vezes é necessário o acompanhamento de profissionais da área da Assistência Social, bem como da Psicologia, que possam avaliar a conveniência da convivência entre o genitor descontínuo e os filhos. Através dessas avaliações o magistrado possuirá mais elementos para determinar a regulamentação das visitas, permitindo ou na o pernoite na casa do genitor descontínuo, viagens e períodos prolongados de convivência, levando em consideração não apenas o relacionamento dos filhos com o genitor descontínuo, mas também as condições em que se desenvolve esse relacionamento, tais quais os hábitos do genitor, as condições do ambiente da sua residência, sua disponibilidade de estar com os filhos, etc.

${ }^{152}$ LAURIA, Flávio Guimarães. A regulamentação de visitas e o princípio do melhor interesse da criança. $2^{\mathrm{a}}$ tiragem. Rio de Janeiro: Lumen Juris, 2003, p. 85-86.

${ }^{153}$ STRENGER, Guilherme Gonçalves. Guarda de filhos. São Paulo: LTr Ed., 1998, p. 122.
} 
por já pressupor um maior amadurecimento dos genitores, que, muito provavelmente, não enfrentarão problemas para o cumprimento do regime de visitas.

É importante frisar, contudo, que, mesmo nos casos em que a regulamentação das visitas é estipulada de comum acordo pelos genitores, o seu cumprimento é essencial para que exerça a sua função de manter os laços afetivos saudáveis entre pais e filhos. Os genitores devem levar em consideração que a sua separação, por si só, já gera transtornos suficientemente difíceis de se lidar para os seus filhos, que passam a ter duas famílias diferentes, quando antes tinham apenas uma. A alteração na rotina, que inclui deixar de estar no convívio diário com o genitor descontínuo, bem como passar a ter datas e horários pré-estabelecidos para conviver com seu pai, ou sua mãe, provoca reações e sentimentos os mais variados nos filhos, o que os confunde e desnorteia. Nesse sentido, aponta FRANÇOISE DOLTO que:

A regularidade é mais importante do que a frequência. Se os pais chegam a um acordo quanto a um dia e um horário, a criança pode ser prevenida: "seu horário ao telefone com seu pai é tal dia e tal hora". Então, é necessário que o pai respeite sua palavra e efetivamente telefone. Caso contrário, a criança fica na expectativa de algo que não vem, e nada é mais terrível para uma criança do que uma promessa que não é cumprida ${ }^{154}$.

A responsabilidade dos genitores, portanto, será redobrada, pois deverão não apenas cuidar dos filhos, como fariam se ainda formassem uma família única, mas ainda cuidar para que a situação de guarda e de visitas decorrente da sua separação seja assimilada pelos filhos da maneira mais natural e serena possível.

Lamentavelmente, contudo, é muito comum que a animosidade entre os genitores impeça o estabelecimento - e, principalmente, o cumprimento - de um regime de visitas consensual, o que fatalmente obrigará à imposição judicial do regime.

A atividade do magistrado, na fixação do regime de visitas, deve levar em consideração diversos fatores, sempre tendo por norte, contudo, o atendimento ao princípio do melhor interesse do menor.

Importante mencionar que, no caso do filho ser criança de tenra idade, ainda em fase de aleitamento, é desaconselhável, por exemplo, estabelecer um regime de pernoite na casa do genitor descontínuo. Nesses casos o ideal é que o pai vá visitar o filho na casa materna, ou mesmo num berçário, onde possa desfrutar por algumas horas do seu convívio.

\footnotetext{
${ }^{154}$ DOLTO, Françoise. Quando os pais se separam. Tradução de Vera Ribeiro. Rio de Janeiro: Jorge Zahar Editor, 1989, p. 65-66.
} 
Contudo, tal contato do pai com o filho de pouca idade é muito importante, porque, para a criança nessa fase, as ligações primeiras com seus pais são essenciais, conforme demonstram JOSEPH GOLDSTEIN et alli:

Tais primárias e tênues ligações iniciais formam a base sobre a qual futuras relações se desenvolvem. O que a criança leva a eles [os pais] não são mais, apenas, suas necessidades de conforto físico e satisfação, mas suas necessidades emocionais por afeição, companheirismo e intimidade estimulante. Onde tais [elementos] são correspondidos de maneira confiável, a relação paterno-filial torna-se firme, com efeitos imensamente produtivos para o desenvolvimento emocional e social da criança ${ }^{155}$.

Tratando-se, diferentemente, de criança cuja idade e desenvolvimento permitam uma maior independência em relação aos cuidados maternos, passa a ser possível que o pai leve o filho para um passeio, por exemplo, em vez de permanecer com a criança na casa materna, até mesmo porque "se as visitas do genitor descontínuo à criança pequena, na casa do genitor contínuo, fossem mais frequentes, poderia resultar daí uma espécie de ambiguidade, como se os pais vivessem juntos, quando de fato isso é falso" ${ }^{\text {156 }}$. Dessa maneira, melhor seria que o genitor descontínuo levasse o filho consigo para que desfrutassem um da companhia do outro ${ }^{157}$, sendo, contudo, desaconselhável a adoção da pernoite, caso as circunstâncias do caso indicassem que a criança poderia se sentir insegura em passar a noite longe da mãe, por sua pouca idade e apenas relativa independência em relação à figura materna ${ }^{158}$.

\subsubsection{A vontade do menor}

${ }^{155}$ GOLDSTEIN, Joseph; SOLNIT, Albert J.; GOLDSTEIN, Sonja; FREUD, Anna. The best interests of the child. New York: The Free Press, 1996, p. 12. Tradução livre de: "such primitive and tenuous first attachments form the base from which further relationships develop. What the child brings to them are no longer only her needs for bodily confort and gratification, but her emotional demands for affection, companionship, and stimulating intimacy. Where these are answered reliably, the child-parent relationship becomes firm, with immensely productive effects on the child's emotional and social development".

${ }^{156}$ DOLTO, Françoise. Quando os pais se separam. Tradução de Vera Ribeiro. Rio de Janeiro: Jorge Zahar Editor, 1989, p. 64.

${ }^{157}$ Nesse sentido, o seguinte acórdão: "Regulamentação de direito de visitas. Preponderância dos interesses da criança. Convivência com o pai que é necessária para seu bom desenvolvimento psicológico e emocional. Direito natural do pai consagrado no art. 1589 do Código Civil de 2002. Visita fora da casa materna, aos domingos, das 9 às 19 horas, que é razoável e se mostra benéfica à formação afetiva da criança. Inexistência motivo concreto para restrição, devendo a autora adaptar sua rotina e da criança para que esta última possa estar na companhia do pai. Jurisprudência dominante neste TJSP e no STJ. Decisão parcialmente reformada.

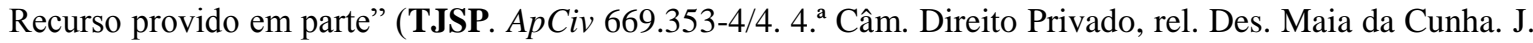
26.11.2009).

${ }^{158}$ Nesse sentido, o seguinte acórdão: "Visita - Decisão que amplia de forma moderada o direito do pai de ter consigo o filho que completou dois anos de idade - Legalidade diante de não existir prova de que alteração prejudica os interesses da criança - Não provimento" (sem grifo no original) (TJSP. AgIn 990.10.209451-0. 4. ${ }^{\text {a }}$ Câm. Direito Privado, rel. Des. Ênio Zuliani. J. 26.08.2009). 
Cuidando o direito de visitas de uma forma de proteger o melhor interesse do menor, garantindo-lhe o direito à convivência familiar com ambos os genitores, surge a questão da vontade do menor na regulamentação do direito de visitas.

CAETANO LAGRASTA NETO, por seu turno, embora reconheça que o menor deve ser consultado, sendo seus sentimentos levados em consideração para a tomada de quaisquer decisões que o envolva, atenta para o fato de que pode ser desaconselhável ouvir o menor na audiência, "onde não são raros os momentos de agressividade, confusão e perplexidade",159.

Contudo, ainda que prefira o magistrado, para atribuir a guarda do menor, ouvir sua opinião, deve-se ter em mente que, se por um lado a preponderância do direito do filho sobre o dos genitores levaria a crer que a vontade daquele deve prevalecer, ou seja, impedindo o contato do genitor descontínuo com o filho caso este assim deseje, deve-se proceder com muita cautela no momento de atribuir valor à vontade do filho, tanto na atribuição da guarda quanto no estabelecimento do regime de visitas.

A vontade da criança, muito embora deva sempre ser levada em consideração, deverá ser sopesada com prudência, conforme a sua idade, seu grau de discernimento e, principalmente, suas condições psicológicas.

Isso porque o direito que a criança tem à convivência familiar é indisponível, justamente porque sua manutenção preserva o seu melhor interesse, qual seja, o de desenvolver-se em laços afetivos com ambos os pais. E nem sempre, ainda que tal seja a exteriorização da sua vontade, o afastamento da criança do genitor descontínuo preserve, de fato, o seu interesse.

Dessa forma, caberá ao magistrado, com o apoio da equipe interprofissional, avaliar se atender à vontade da criança - seja no sentido de estabelecer, manter, ampliar ou suspender o regime de visitas - é a melhor solução para ela mesma. Isso porque as crianças, especialmente as mais novas, são muito suscetíveis de serem influenciadas pelos adultos - por exemplo o genitor guardião. Portanto, a recusa do filho, ainda que incisiva e determinada, de estar com o genitor descontínuo, pode decorrer de um processo de Alienação Parental, o que deverá ser identificado pelos profissionais envolvidos no caso ${ }^{160}$.

\subsubsection{A regulamentação do direito de visitas}

\footnotetext{
${ }^{159}$ LAGRASTA NETO, Caetano. Direito de Família - A família brasileira no final do século XX. São Paulo: Malheiros Ed., 2000, p. 127.

${ }^{160}$ Sobre esse tema se discorrerá com mais profundidade na Parte II.
} 
A partir de certo estágio de desenvolvimento da criança e da sua relação com o genitor descontínuo, conforme seja identificado pelo magistrado com o auxílio de equipe interprofissional, deve haver uma ampliação no regime de visitas, permitindo-se que o menor permaneça na companhia do genitor que não detém a guarda por um lapso temporal maior $^{161}$, inclusive com a possibilidade de dormir na casa do genitor descontínuo. Acerca disso, sustenta PATRÍCIA DAHER LAZZARINI que

O pernoite serve para que a convivência se dê em clima de maior intimidade. É por meio dele que o genitor participará mais efetivamente dos hábitos da criança, sejam eles alimentares ou de sono, assim como pai e filho disporão de tempo mais contínuo para a realização de alguma atividade e para o diálogo ${ }^{162}$.

Dessa maneira, para que esse convívio entre o genitor descontínuo e os filhos seja garantido, a regulamentação do regime de visitas deve ser tão detalhada quanto for possível, podendo adotar formas diversas, como se verá a seguir.

\subsubsection{Visitas livres}

O sistema de visitas livres, em que apenas é acordado que o genitor descontínuo possui o direito de ver os filhos, porém sem estabelecer sequer uma regulamentação mínima, é desaconselhável de ser adotado, tanto pelos pais, como pelo magistrado. Mesmo nos casos em que os pais concordam com a ampla liberdade do regime de visitas, uma regulamentação, ainda que mínima, é preferível, até porque torna o cumprimento do direito de visitas mais eficaz em caso, por exemplo, de futuro desacordo entre os genitores. Isso porque, caso não haja uma pré-determinação judicial do regime, será necessário ingressar com ação de conhecimento, caso o processo que tratou da atribuição da guarda já esteja encerrado e não comporte, portanto, um pedido incidental de regulamentação do regime de visitas. Se tal regulamentação já existir, em caso de descumprimento por parte do guardião bastará executar o acordo.

Além disso, conforme entende FRANÇOISE DOLTO sobre a necessidade de se estabelecer algumas datas prefixadas para a visita do genitor descontínuo, "é preciso que haja datas previamente conhecidas por ela [a criança]. Que a criança saiba de antemão, e

\footnotetext{
${ }^{161}$ Nesse sentido, o seguinte acórdão: “Regulamentação de visitas proposta pelo genitor do menor. Pretensão de ampliar o horário estabelecido em acordo judicial - Estudo psicossocial com conclusão de que o contato da criança é benéfico e que não há impedimentos para a ampliação das visitas - Melhor interesse do menor (...)” (TJSP. ApCiv 566.457.4/8-00. 3. . Câm. Direito Privado, rel. Des. Egídio Giacoia. J. 01.12.2009).

${ }^{162}$ LAZZARINI, Patrícia Daher. A proteção da criança pelo exercício da guarda de menores e da visita. Dissertação de Mestrado. Faculdade de Direito da Universidade de São Paulo. São Paulo, 2009, p. 137.
} 
que isso efetivamente aconteça (...). Os referenciais no espaço e no tempo são necessários a todas as crianças: esses referenciais são os de um ser humano vivo"163.

É muito importante, dessa maneira, que se aja acauteladamente, adotando-se um regime de visitas. Ainda que o direito de visitas seja sempre cumprido satisfatoriamente pelos genitores, sem quaisquer atritos entre eles, a experiência demonstra que as chances de, eventualmente, surgirem desentendimentos, são grandes. Portanto, para que o próprio interesse dos filhos seja preservado, é de todo conveniente que, ainda que consensualmente, seja estabelecido um regime mínimo de visitas, que sirva de garantia ao convívio familiar entre o genitor descontínuo e seus filhos.

\subsubsection{Fins de semana alternados}

Na maioria dos casos de regulamentação de visitas, em que a idade e as condições pessoais do filho já permitem que se afaste da mãe por um lapso temporal maior, estabelece-se o regime dos fins de semana alternados, em que, como o próprio nome indica, cabe ao genitor descontínuo ter o filho em sua companhia a cada quinze dias, durante o fim de semana, que pode iniciar-se na sexta-feira à noite ou no sábado de manhã, terminando no domingo ao fim do dia ou mesmo na segunda-feira pela manhã, nas hipóteses em que, se o filho estudar no período matutino, o genitor descontínuo o deixe diretamente na escola - o que é recomendável, porque inclusive estimula o contato do genitor descontínuo com a escola do filho ${ }^{164}$.

Essa forma de regime pode incluir, ainda, visitas semanais, geralmente às quartasfeiras, por períodos mais curtos - algumas horas após a saída do fillho da escola, por exemplo, ou um jantar, uma sessão de cinema. A adoção dessa visita semanal é salutar, pois amplia o contato do filho com o genitor descontínuo, que, no regime que prevê apenas fins de semana alternados, conviveria com o filho apenas duas vezes por mês, o que é, de fato, muito pouco.

\subsubsection{Férias escolares}

As férias escolares constituem um período essencial para a manutenção dos laços afetivos e do convívio dos filhos com o genitor descontínuo, porque propicia entre eles um

\footnotetext{
${ }^{163}$ DOLTO, Françoise. Quando os pais se separam. Tradução de Vera Ribeiro. Rio de Janeiro: Jorge Zahar Editor, 1989, p. 62-63.

${ }^{164}$ LAURIA, Flávio Guimarães. A regulamentação de visitas e o princípio do melhor interesse da criança. $2^{\mathrm{a}}$ tiragem. Rio de Janeiro: Lumen Juris, 2003, p. 88-89.
} 
contato prolongado ${ }^{165}$, e, portanto, deve ser objeto de regulamentação, respeitadas, conforme já mencionado, as peculiaridades de cada caso (se o filho for muito novo não é recomendado que fique longe da mãe por período demasiadamente prolongado). Dessa forma, tanto no recesso de julho quanto nas férias de fim de ano, os filhos podem passar metade do tempo com cada genitor.

\subsubsection{Feriados prolongados}

Com relação aos feriados prolongados, em que as pessoas costumam realizar viagens de lazer, o ideal é que sejam repartidos o mais igualitariamente possível entre os genitores, para que os filhos possam desfrutar igualmente do convívio com ambos ${ }^{166}$. Dessa maneira, se a simples divisão dos fins de semana contemplar mais um genitor do que o outro no que se refere aos feriados prolongados, pode-se proceder à sua modificação, a fim de promover uma divisão mais equânime.

\subsubsection{Natal e Ano Novo}

Por serem, via de regra, feriados comemorados no âmbito familiar, com reunião de parentes e amigos, o usual é que os filhos passem o Natal com um genitor e o Ano Novo com o outro, invertendo-se a ordem no ano seguinte ${ }^{167}$. Nada impede que os genitores,

\footnotetext{
${ }^{165}$ Nesse sentido, o seguinte acórdão: "Regulamentação de visitas - Pretensão do pai que enfrenta resistência da mãe para exercer seu direito de visita e de pernoitar com os filhos menores - Ausência de prova que indique o efeito nocivo das visitas ou de pernoite - Fixação de divisão de férias escolares que independem de comprovação prévia dos dias em que o pai estará de férias do seu trabalho - Férias no mês de julho que, em regra, são de um mês e que, se diversas, devem ser redistribuídas em momento em que forem definidas pela escola - Não provimento" (TJSP. ApCiv 580.814.4/0-00. 4. ${ }^{a}$ Câm. Direito Privado, rel. Des. Ênio Santarelli Zuliani. J. 15.01.2009).

${ }^{166}$ Nesse sentido, o seguinte acórdão: "Pedido de regulamentação de visita - interesse da criança - adequação. - É patente o direito do agravado, genitor da menor, de visitá-la, sendo indispensável a sua presença na vida desta, com evidente contribuição no seu desenvolvimento, devendo a visitação ser regulamentada de forma a atender os melhores interesses da infante (...).Trata-se de agravo de instrumento interposto contra a decisão (...) que (...) ampliou o direito de visitas do requerido, para este ter a criança em sua companhia em finais de semana alternados, das 18 horas de sexta-feira às 11 horas de segunda-feira, podendo viajar com a criança. $\mathrm{A}$ referida decisão determinou, ainda, que no feriado de 7 de setembro a criança deverá permanecer com o pai das 18 horas de sexta-feira às 11 horas de terça feira, alternando-se nos demais feriados (...). É patente o direito do agravado, genitor da menor, de visitá-la, sendo indispensável a sua presença na vida desta, com evidente contribuição no seu desenvolvimento, devendo a visitação ser regulamentada de forma a atender os melhores interesses da infante (...).E, na hipótese dos autos, diante de todos os fundamentos já delineados, e tendo em vista o melhor interesse da menor (...), entendo que a v. decisão deve mantida" (TJMG. AgIn 1.0024.07.668069-3/004. 1. ${ }^{a}$ Câm. Cív. rel. Des. Eduardo Andrade. J. 17.11.2009).

${ }^{167}$ Nesse sentido, o seguinte acórdão: “Apelação cível. Direito de família. Regulamentação de visita. Guarda dos menores com a mãe e visitação ao pai fixada em finais de semana e feriados prolongados, alternadamente, dia dos pais e aniversário, além de Natal e Carnaval dos anos pares, Ano Novo dos anos ímpares e primeira metade das férias escolares. Inconformismo da genitora pretendendo a redução da visita para três horas mensais. Acordo provisório por mais de 01 ano, devidamente cumprido pelo genitor. Estudo social e psicológico favorável à maior convivência do genitor com seus filhos. Dificuldades emocionais da
} 
atendendo às circunstâncias, alterem a ordem estabelecida no regime. $\mathrm{O}$ importante é que os filhos tenham a oportunidade de comemorar tais festividades com o pai e a mãe e suas respectivas famílias.

\subsubsection{Datas comemorativas}

As principais datas comemorativas que podem fazer parte do regime de visitas são o dia dos pais, o dia das mães, os aniversários dos genitores, o dia das crianças e, principalmente, o aniversário dos filhos.

Com relação às primeiras datas não há problemas: os filhos passam o dia das mães, bem como o aniversário desta, com a mãe, e passam o dia dos pais, bem como o aniversário deste, com o pai ${ }^{168}$. Ressalvada a hipótese de ambos os genitores fazerem aniversário no mesmo dia, a companhia dos filhos em tais datas são reguladas dessa forma.

No dia das crianças, que no Brasil é sempre feriado nacional por coincidir com o dia da padroeira, o mais indicado é que os filhos permaneçam com o genitor em cuja companhia estiverem no dia (já que o feriado pode coincidir com o dia de visitas do genitor descontínuo), cabendo ao outro genitor algumas horas na companhia dos filhos.

O aniversário dos filhos é a data mais conflituosa na regulamentação do regime de visitas. Isso porque, via de regra, ressalvada a hipótese de boa convivência entre os genitores, nenhuma das soluções possíveis é totalmente satisfatória. Não é recomendável que a comemoração do aniversário do filho seja alternada, num ano com um genitor, no seguinte com o outro. $\mathrm{O}$ aniversário é uma data especial, principalmente para a criança, e por esse motivo o mais recomendado é que o filho possa desfrutar da companhia e do carinho tanto do pai quanto da mãe nessa data.

O mais recomendado, obviamente, é que se faça apenas uma festa, com a presença de ambos os genitores e de suas famílias. Contudo, isso, na prática, é muito difícil de ocorrer. Dessa forma, as duas soluções mais recomendáveis são: 1) Dividir o dia do aniversário entre os genitores (podendo-se alternar os períodos a cada ano), permitindo que o filho comemore o aniversário não apenas com os pais, mas também com suas respectivas famílias; 2) Alternar-se, anualmente, a quem caberá realizar a festa de aniversário, devendo

genitora em lidar com ex-cônjuge não justificam sejam os filhos privados da convivência paterna. Direito inalienável do genitor e interesse dos menores. Inexistência de elemento que desaconselhe à convivência paterna. Parecer favorável da douta procuradora de justiça. Desprovimento do recurso" (TJRJ. ApCiv 0002218-54.2004.8.19.0002 (2008.001.41970). 8. ${ }^{a}$ Câm. Cív., rel. Des. Norma Ribeiro. J. 02.12.2008).

${ }^{168}$ Pode ser, ainda, que se estabeleçam critérios para que os filhos possam comemorar os aniversários dos avós, caso seu relacionamento com eles indique tal medida. 
o genitor que organizá-la permitir a participação do outro. O que importa, essencialmente, é que o filho possa receber o carinho de ambos os genitores na especial data do seu aniversário.

\subsubsection{O local onde devem ocorrer as visitas}

Nem sempre é possível, ou recomendável, que o genitor descontínuo retire o filho durante o período de visita, levando-o consigo para sua casa ou para passeios. Diversas são as situações que podem desaconselhar a adoção dessa forma de visita, como a tenra idade da criança, ou alguma espécie de conflitualidade na relação entre o genitor descontínuo e o filho, ou mesmo dúvidas razoáveis acerca da capacidade do genitor não guardião de cuidar adequadamente do menor.

Nessas hipóteses, existem algumas soluções que podem ser adotadas para não se eliminar a possibilidade do convívio entre o filho e o genitor que não detém a sua guarda. É o que se verá a seguir.

\subsubsection{Visita na casa materna ou em berçário}

Sendo o filho criança de poucos meses de vida, portanto ainda em fase de aleitamento materno - período esse em que demanda muitos cuidados específicos que, via de regra, são mais satisfatoriamente providos pela mãe -, convém que as visitas do genitor descontínuo se dêem na casa materna, por períodos não prolongados ${ }^{169}$. Caso a relação entre os genitores impossibilite tal solução, pode o magistrado determinar que a mãe leve o bebê a um berçário, onde o pai poderá visitá-la. Muito embora nessa fase da vida da criança o convívio com o pai não seja essencial para o estabelecimento dos vínculos afetivos, o contato entre os dois será, sem dúvida, salutar, devendo, portanto, ser estimulado tanto quanto seja possível.

\subsubsection{Visita assistida}

\footnotetext{
${ }^{169}$ Nesse sentido o seguinte acórdão: "Regulamentação de Visitas. Decisão que determinou que o agravante terá direito de visitar seu filho, quinzenalmente, aos domingos, das 14 às 17 horas. Admissibilidade. Criança em tenra idade necessitando de amamentação" (TJSP. AgIn 990.10.248560-9. 4. ' Câm. de Direito Privado, rel. Des. Fábio Quadros. J. 08.07.2010).
} 
ROBERTO JOÃO ELIAS destaca que o direito de visitas pode, para o bem do menor, ser restringido ou limitado ${ }^{170}$. Uma das formas de restrição é a obrigatoriedade de acompanhamento da visita, "até que haja uma melhor adaptação entre a criança e o pai e a mãe. Dependendo da reação do filho, as visitas podem ser modificadas, até que estabelecido um relacionamento adequado, quando, então, elas poderão ser fixadas normalmente" ${ }^{, 171}$.

Nesta modalidade, determina-se a presença, durante a visita, de um profissional designado pelo juízo - um psicólogo ou um assistente social, por exemplo -, para permitir um contato gradual entre o genitor descontínuo e o filho, nos casos em que ainda se discute a guarda do menor, ou mesmo a regulamentação das visitas. Tal forma de visita serve, principalmente, para que os profissionais que dela participam possam verificar se é salutar a concessão definitiva do direito de visitas desacompanhadas. ${ }^{172}$

O psicólogo e perito judicial SIDNEY SHINE, em obra acerca da atividade do psicólogo nas disputas pela guarda dos filhos, menciona a avaliação psicológica do menor e dos genitores como uma forma de identificar a afinidade da criança com seus pais ${ }^{173}$. Dessa maneira, o acompanhamento realizado por um profissional da Psicologia durante as visitas pode ajudar a avaliar se o genitor descontínuo possui condições de ter o filho em

\footnotetext{
${ }^{170}$ Nesse sentido, o seguinte acórdão: "Agravo de instrumento. Regulamentação de visitas e guarda. Visitação assistida. Decisão que fixou o regime inicial de visitação em favor do pai, ainda que pendente o estudo social e a avaliação psicológica dos envolvidos. Documentos acostados que comprovam que o agravado foi forçado a buscar tratamento especializado. Menor que conta com apenas dois anos e cinco meses de idade, necessitando de cuidados especiais e compatíveis com a total ausência de discernimento e de independência para a realização de qualquer tarefa sozinha, seja alimentação ou higiene. Direito à visitação que pode ser limitado em casos especiais, como no caso destes autos, onde se verifica que a pouquíssima idade da menor impõe a observância de cuidados específicos e essenciais à sua segurança, saúde, bem estar e equilíbrio emocional, diligências que, em princípio, podem ser negligenciadas em razão dos problemas enfrentados por seu pai. Precedentes deste Tribunal neste sentido. Provimento jurisdicional relativo à guarda ou a visitação de filho que não faz coisa julgada material, razão porque pode ser revisto a qualquer tempo.

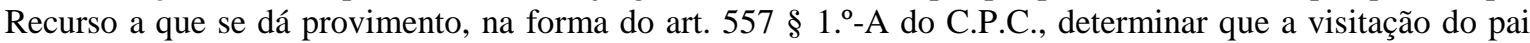
seja acompanhada pela agravante ou pessoa por ela indicada" (TJRJ. AgIn 0032375-06.2010.8.19.0000. 10. ${ }^{\text {a }}$ Câm. Cív., rel. Des. Gilberto Dutra Moreira. J. 20.07.2010).

${ }^{171}$ ELIAS, Roberto João. Comentários ao Estatuto da Criança e do Adolescente: (Lei n. 8.069, de 13 de julho de 1990). 2. ed. São Paulo: Saraiva, 2004, p. 66.

${ }_{172}$ Nesse sentido, o seguinte acórdão: "A conduta da mãe, não denota condições de promover, com segurança, nesta fase processual, um convívio harmonioso (...), devendo-lhe ser mantido o direito de visitas, mas sob supervisão, até ulterior deliberação do MM. Juízo inaugural. Sendo assim, no caso em tela a relação materno-filial deve ser preservada, sem prejuízo da relação paterno-filial, assegurando à Agravada o direito de visitas, reformando a decisão vergastada apenas para conceder o direito de visita da sua filha aos sábados das 9 às 18 hs acompanhada de assistente social a ser indicada pelo MM. Juízo (...)" (sem grifo no original) (TJBA. AgIn 79494-5/2008. 5. ${ }^{a}$ Câm. Cív., rel. Des. Antônio Roberto Gonçalves. J. 13.10.2009).

${ }^{173}$ SHINE, Sidney Kiyos. A espada de Salomão: a psicologia e a disputa de guarda de filhos. São Paulo: Casa do Psicólogo, 2003, p. 147.
} 
sua companhia sem o acompanhamento de terceiros - seja o próprio genitor guardião, uma babá por este escolhida ou ainda um profissional indicado pelo juízo ${ }^{174}$.

\subsubsection{Visita em estabelecimentos especializados}

Para propiciar a possibilidade do genitor descontínuo e seus filhos manterem o convívio familiar, nas hipóteses em que o interesse do menor exigir tal cautela, poderá o magistrado determinar que a visita ocorra em um estabelecimento especializado, como o CEVAT (Centro de Visitas Assistidas do Tribunal), criado pelo Tribunal de Justiça de São Paulo, na capital paulista ${ }^{175}$.

FRANÇOISE DOLTO menciona solução semelhante adotada na capital francesa:

Creio nas possibilidades oferecidas pelos hotéis-dia aos filhos que têm de esperar pelo genitor que os vai visitar. Houve uma fundação que estabeleceu uma hotelaria desse tipo em Paris, com salão de jogos e locais para reunião. E havia educadores lá. É em locais assim que a criança poderia esperar pelo pai no dia previsto para a visita. E seria preciso que, nesse dia, a mãe não tivesse o direito de conservar o filho com ela. Que se dissesse às mães que elas não têm de guardar a criança no dia reservado ao pai" ${ }^{, 176}$.

O Fórum, via de regra, deve ser evitado como local para que ocorram as visitas entre o genitor descontínuo e os filhos. Trata-se não apenas de um local inapropriado para crianças, como também um ambiente que não propicia o clima de alegria e descontração que deve existir durante o convívio entre o genitor e seus filhos. Além disso, trata-se justamente do local onde se desenrola a disputa entre os pais pelos próprios filhos, o que, por si só, já seria motivo suficiente para não se considerar o Fórum um local adequado para o exercício do direito de visitas.

\footnotetext{
${ }^{174}$ Nesse sentido, o seguinte acórdão: “Agravo de instrumento. Civil. Direito de família. Ação cautelar. Guarda. Menor. Decisão que defere a visitação sem acompanhamento de babá. Pertinência. Ameaça à integridade física ou psicológica da menor. Ausência de comprovação. 1. Correta a decisão que defere ao pai visitar a filha sem que a mesma esteja acompanhada de babá, quando tal providência revela-se desnecessária e em nada atende aos interesses da menor. 2. Recurso improvido" (sem grifo no original)

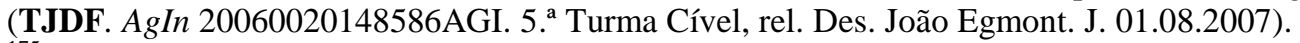

${ }^{175}$ Nesse sentido, o seguinte acórdão: "Regulamentação de visitas - Recurso que almeja a suspensão do direito de visitas do genitor à criança no CEVAT, bem como a revogação da multa fixada, para o caso de descumprimento - Visitação determinada com base em recomendação do relatório psicológico e que melhor atende aos interesses da criança - Agravante que não possibilita as visitas - Multa corretamente aplicada - Decisão mantida - Recurso conhecido e desprovido. (...) A determinação de que as visitas devam ocorrer no CEVAT estão lastreadas em minucioso estudo psicológico (...) e visa ao resguardo dos direitos da criança à convivência com o seu pai. $O$ estudo psicológico já salientou que o menor vem sendo revitimizado com a ausência do pai, pois possui vínculos fortes com ele (...) (sem grifo no original) (TJSP. AgIn 663.853-4/2-00. 1. ${ }^{\text {a }}$ Câm. Direito Privado, rel. Des. De Santi Ribeiro. J. 15.12.2009).

${ }^{176}$ DOLTO, Françoise. Quando os pais se separam. Tradução de Vera Ribeiro. Rio de Janeiro: Jorge Zahar Editor, 1989, p. 57.
} 


\subsection{Infração ao regime de visitas e medidas cabíveis para o seu cumprimento coercitivo}

O genitor guardião não possui apenas o dever de permitir que o genitor descontínuo exerça o seu direito-dever de visitas. Não se trata de uma obrigação de não fazer, mas sim de uma obrigação de fazer: como o interesse protegido é o do filho - qual seja, o de desfrutar da convivência com o genitor descontínuo, como forma de alcançar o seu pleno desenvolvimento psicossocial -, e como o genitor guardião possui o dever jurídico, constitucionalmente imposto, de garantir, com absoluta prioridade, o direito do seu filho à convivência familiar ${ }^{177}$, resta claro que o genitor que detém a guarda possui o dever de estimular o convívio do filho com o genitor descontínuo, através do cumprimento adequado do regime de visitas ${ }^{178}$.

$\mathrm{Na}$ Argentina, conforme ensinam GUSTAVO A. BOSSERT e EDUARDO A. ZANNONI,

Em 1993 sancionou-se a Lei 24.270, que tipifica um novo delito penal que se pode denominar delito de obstrução do direito de visitas. $\mathrm{O}$ artigo $1 .^{\circ}$ da lei dispõe que "será punido com prisão de um mês a um ano o genitor ou terceiro que, ilegalmente, impedir ou obstruir o contato de menores com seus genitores não conviventes. Tratando-se de menor de dez anos ou de incapaz, a pena será de seis meses a três anos de prisão" ${ }^{\text {"179 }}$.

Dessa maneira, não apenas o Poder Judiciário pode, mas deve coibir quaisquer formas de obstrução que o genitor guardião busque, conscientemente ou não, impor à convivência sadia entre o filho e o genitor descontínuo ${ }^{180}$. Nas palavras de FRANÇOISE

\footnotetext{
177 Cf. art. 227, Constituição Federal.

${ }^{178}$ Nesse sentido, o seguinte acórdão: “Agravo Interno. Art. 557, § 1. ${ }^{\circ}$, CPC. Regulamentação de direito de visitas. Exercício que deve ser realizado em vista do interesse do menor. Estabelecimento de vínculo com o pai que é salutar para o desenvolvimento da criança. Dever de quem detém a guarda do filho facilitar a visita do outro. Direito de visita que, salvo situação excepcional, não vislumbrada no caso concreto, deve ser exercido amplamente e fora da casa materna. Restabelecimento do regime de visitas nos moldes anteriormente acordados que é de rigor. Recurso provido por decisão monocrática. Agravo interno improvido" (sem grifo no original) (TJSP. Ag. Interno 678.546-4/8-01. 4. a Câm. Direito Privado, rel. Des. Maia da Cunha. J. 13.01.2010).

${ }^{179}$ BOSSERT, Gustavo A.; ZANNONI, Eduardo A. Manual de derecho de familia. 5. ed., actualizada y ampliada. Buenos Aires : Editorial Astrea, 2001, p. 396. Tradução livre de "En 1993 se sancionó la ley 24.270, que tipifica un nuevo delito penal al que se puede denominar delito de obstrucción del derecho de visitas. El art. $1 .^{\circ}$ de la ley dispone que "será reprimido con prisión de un mes a un año el padre o tercero que, ilegalmente, impidiere o obstruyere el contacto de menores con sus padres no convivientes. Si se tratare de un menor de diez años o de un descapacitado, la pena será de seis meses a tres años de prisión".

${ }^{180}$ Nesse sentido, o seguinte acórdão: "Se o acórdão recorrido estabelece que o pai possui interesse de estar presente e visitar a filha o tanto quanto lhe for permitido, conforme determinação do Juízo na regulamentação de visitas, cumprindo, por conseguinte, com suas obrigações paternas, demonstrando intensa preocupação e cuidado com o bem estar da menor, tendo-se apenas em perspectiva real o fator de intenso conflito
} 
DOLTO, "a sociedade deve ajudar a mãe a não impedir o pai de cumprir seu dever de visita" 181 .

Nesse mesmo sentido se posiciona JOSÉ FERNANDO SIMÃO, para quem:

No momento em que houver litígio quanto à guarda dos filhos (parentalidade), entre a vontade egoística dos cônjuges e o bemestar do menor, prevalece o segundo sobre a primeira (art. 1.584 do CC). Entre a vontade dos cônjuges e o interesse do menor, que é valor que interessa a toda sociedade, prevalece o interesse da coletividade em detrimento do sentimento do particular. (...) Proteger a criança e o adolescente é proteger a coletividade, é proteger o futuro ${ }^{182}$.

Conforme será tratado de maneira mais detalhada na Parte II, é no descumprimento do regime de visitas que, na maioria das vezes, se inicia o processo de afastamento entre o genitor descontínuo e o filho, afastamento esse frequentemente promovido pelo próprio genitor guardião. As consequências do abortamento artificial da relação entre o filho e o genitor que não detém a sua guarda podem impedir de maneira definitiva a convivência entre eles, causando danos psicológicos em ambos. FRANÇOISE DOLTO afirma que:

Por vezes, é impossível para uma criança que mora sozinha com a mãe poder "encarar o pai numa boa", já que a maneira como a mãe a faz vivenciar sua relação com o ex-cônjuge perturba inteiramente o trânsito e a vida vegetativa dessa criança. A criança fica perturbada quando a mãe lhe fala do pai como um homem perigoso ou indiferente, pelo fato de que ele parecia não cuidar do filho quando este era pequeno ${ }^{183}$.

A propósito, é importante ressaltar que, muitas vezes, o genitor contínuo não age de maneira sistemática, buscando impedir o contato do filho com o outro genitor propositalmente, como forma de vingança ou simplesmente para minar o relacionamento entre eles. Contudo, muito embora o magistrado deva levar tais circunstâncias em consideração, não pode se furtar a agir para que tal prática seja obstada.

FLÁVIO GUIMARÃES LAURIA, sobre a violação ao direito de visitas, lembra que:

vivenciado entre os genitores, não há porque restringir o salutar contato da filha com pai" (STJ. REsp 1032875 / DF. 3. ${ }^{\text {a }}$ Turma, rel. Min. Nancy Andrighi. J. 28.04.2009).

${ }^{181}$ DOLTO, Françoise. Quando os pais se separam. Tradução de Vera Ribeiro. Rio de Janeiro: Jorge Zahar Editor, 1989, p. 58.

${ }^{182}$ SIMÃO, José Fernando. Ser ou não ser: outorga conjugal e solidariedade familiar. Revista Brasileira de Direito das Famílias e Sucessões. Porto Alegre, n. 3, p. 64, abr/mai de 2008.

${ }^{183}$ DOLTO, Françoise. Quando os pais se separam. Tradução de Vera Ribeiro. Rio de Janeiro: Jorge Zahar Editor, 1989, p. 56. 
Em todos os casos, quer se trate de violação por ação ou por omissão, estamos diante de um ato ilícito, caracterizado pela violação de um dever jurídico preexistente, que, como tal, vai repercutir na esfera jurídica alheia. Neste caso, em razão dos aspectos estruturais da relação jurídica decorrente do regime de visitas, nota-se que o descumprimento por um dos genitores vai repercutir tanto na esfera jurídica do filho, que tem, como já demonstrado, o direito de ser visitado, quanto na esfera jurídica do outro genitor, que tem o direito ao compartilhamento dos deveres relativos à criação e educação do filho (caso a violação parta do visitador), ou o direito de visitar, de estar com seu filho que não vive sob sua guarda (caso a violação parta do guardião). Evidentemente que a violação do dever em relação ao filho assume uma posição de prioridade em razão do princípio do melhor interesse da criança, o que não descarta a lesão à situação subjetiva ativa do outro genitor $^{184}$ (sem grifo no original).

A obstrução ao direito de visitas, assim, deve ser, por todos os meios, obstadas pelo juiz $^{185}$, sob pena de afrontar-se não apenas o direito do genitor descontínuo, mas, principalmente, os superiores interesses dos filhos menores. A seguir tratar-se-á de alguns meios de se combater o desrespeito ao regime de visitas.

\subsubsection{Busca e apreensão}

A busca e apreensão de menores, no âmbito do descumprimento do direito de visitas, muito embora por vezes pareça ser a única solução para garantir o cumprimento do regime determinado, é medida que deve ser evitada ao máximo. Isso porque se trata de uma situação demasiadamente desgastante, principalmente para os principais interessados - os filhos menores, que certamente terão muita dificuldade em compreender por que motivo pessoas estranhas estão entrando na sua casa e tirando-os à força da mãe, para leválos ao pai (ou vice-versa).

\footnotetext{
${ }^{184}$ LAURIA, Flávio Guimarães. A regulamentação de visitas e o princípio do melhor interesse da criança. $2^{\mathrm{a}}$ tiragem. Rio de Janeiro: Lumen Juris, 2003, p. 96.

${ }_{185}$ Nesse sentido, o seguinte acórdão: "Agravo de instrumento. Família. Alteração de guarda. Impossibilidade. Obstaculização de visitas do genitor à filha. Descumprimento de acordo homologado judicialmente. Adoção de outras medidas para o cumprimento da avença. A alteração de guarda, neste momento processual, sem maior dilação probatória acerca das condições da genitora de exercer a maternagem, poderá causar maiores prejuízos aos interesses da criança. O descumprimento do acordo de visitação por parte da genitora deve ser resolvido, conforme decisão recorrida, pela busca e apreensão da menina e fixação de multa diária por descumprimento a ser paga pela genitora, sem prejuízo, se for o caso, de

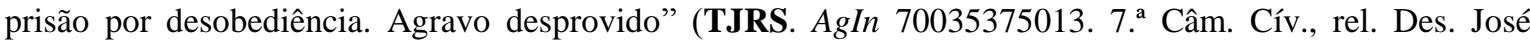
Conrado Kurtz de Souza. J. 22.09.2010. v.u.).
} 
Contudo, o ordenamento jurídico permite que o Judiciário se valha dessa ferramenta para regularizar a situação do regime de visitas ${ }^{186}$. Havendo sentença que tenha fixado o regime de visitas, e sendo a determinação descumprida por qualquer dos genitores, poderá o juiz expedir, em sede de medida cautelar específica, mandado de busca e apreensão, nos termos dos arts. 839 e 842 do Código de Processo Civil:

Art. 839. O juiz pode decretar a busca e apreensão de pessoas ou de coisas.

Art. 842. O mandado será cumprido por dois oficiais de justiça, um dos quais o lerá ao morador, intimando-o a abrir as portas.

$\S 1 .^{\circ}$ Não atendidos, os oficiais de justiça arrombarão as portas externas, bem como as internas e quaisquer móveis onde presumam que esteja oculta a pessoa ou a coisa procurada.

$\S 2 .^{\circ}$ Os oficiais de justiça far-se-ão acompanhar por duas testemunhas.

Além disso, o art. 461 do Código de Processo Civil traz, no texto do seu caput, conjuntamente com o seu $\S 5 .^{\circ}$, a busca e apreensão como medida cabível para o descumprimento de obrigação de fazer, medida que pode ser adotada caso não haja sentença prévia estipulando o regime de visitas (hipótese em que bastará a expedição do mandado de busca e apreensão descrito acima), em procedimento ordinário de caráter satisfativo.

Art. 461. Na ação que tenha por objeto o cumprimento de obrigação de fazer ou não fazer, o juiz concederá a tutela específica da obrigação ou, se procedente o pedido, determinará providências que assegurem o resultado prático equivalente ao adimplemento.

\section{(...)}

$\S 5 .^{\circ}$ Para a efetivação da tutela específica ou para a obtenção do resultado prático equivalente, poderá o juiz, de ofício ou a requerimento, determinar as medidas necessárias, tais como a busca e apreensão, remoção de pessoas e coisas, desfazimento de obras, impedimento de atividade nociva, além da requisição de força policial (sem grifo no original).

Conforme exposto, contudo, a busca e apreensão de menores, com vistas ao cumprimento coercitivo do regime de visitas, deve ser utilizada pelo magistrado com

\footnotetext{
${ }^{186}$ Nesse sentido, o seguinte acórdão: “Apelação cível. Ação de busca e apreensão de menor. Guarda exercida pelo genitor. Conduta repreensível da genitora. Não se pode albergar a conduta da genitora que, contrariando acordo judicial quanto à guarda do filho, a qual vinha sendo exercida pelo genitor, deixa de devolver a criança, sem qualquer motivo relevante. Negaram provimento ao apelo" (TJRS. ApCiv 70029896081. 8. ${ }^{\mathrm{a}}$ Câm. Cív., rel. Des. Alzir Felippe Schmitz. J. 30.07.2009).
} 
extrema cautela e parcimônia, por poder constituir medida demasiadamente traumatizante para os filhos. O ideal é que sejam utilizadas medidas alternativas, que tenham o poder de constranger o genitor ao cumprimento do estabelecido no acordo, sem que seja necessário envolver a pessoa do filho de maneira tão direta e estressante.

\subsubsection{Multa cominatória}

A multa cominatória, ou astreinte, como é conhecida, possui natureza pública, pois serve, em primeiro plano, não para satisfazer o interesse privado da parte a que beneficia, mas para garantir a eficácia da decisão judicial. Noutras palavras, a multa coercitiva deve ser imposta pelo magistrado, de ofício, sempre que a parte negar-se a cumprir a determinação a ela imposta. Além disso, conforme o próprio nome indica, possui um caráter coercitivo, o que significa que a multa não possui qualquer ligação direta com o objeto da obrigação imposta pelo juízo, servindo apenas e tão-somente para obrigar a parte ao cumprimento da decisão judicial ${ }^{187}$.

O estatuto processual civil brasileiro dispõe acerca da multa coercitiva em seu art. $461, \S 2 .^{\circ}$ :

Art. 461. Na ação que tenha por objeto o cumprimento de obrigação de fazer ou não fazer, o juiz concederá a tutela específica da obrigação ou, se procedente o pedido, determinará providências que assegurem o resultado prático equivalente ao adimplemento.

\section{(...)}

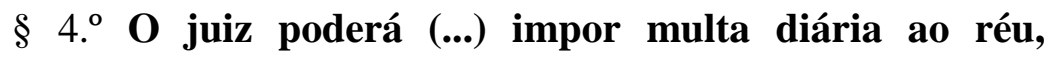
independentemente de pedido do autor, se for suficiente ou compatível com a obrigação, fixando-lhe prazo razoável para o cumprimento do preceito (sem grifo no original).

Demonstra-se salutar a utilização, pelo magistrado, da multa cominatória como forma de garantir o cumprimento do regime de visitas ${ }^{188}$. É uma boa alternativa à busca e

\footnotetext{
${ }^{187}$ LAURIA, Flávio Guimarães. A regulamentação de visitas e o princípio do melhor interesse da criança. $2^{\mathrm{a}}$ tiragem. Rio de Janeiro: Lumen Juris, 2003, p. 123.

${ }^{188}$ Nesse sentido, os seguintes acórdãos: "Regulamentação de visitas - Recurso que almeja a suspensão do direito de visitas do genitor à criança no CEVAT, bem como a revogação da multa fixada, para o caso de descumprimento - Visitação determinada com base em recomendação do relatório psicológico e que melhor atende aos interesses da criança - Agravante que não possibilita as visitas - Multa corretamente aplicada - Decisão mantida - Recurso conhecido e desprovido. (...) A determinação de que as visitas devam ocorrer no CEVAT estão lastreadas em minucioso estudo psicológico (...) e visa ao resguardo dos direitos da criança à convivência com o seu pai. O estudo psicológico já salientou que o menor vem sendo revitimizado com a ausência do pai, pois possui vínculos fortes com ele (...). A postura da recorrente em não possibilitar as visitas revela uma renitência exacerbada ao comando judicial e, portanto, não pode passar
} 
apreensão, por restringir seus efeitos às partes litigantes - os genitores -, não refletindo, ao menos diretamente, nos filhos.

\subsubsection{Inversão da guarda, suspensão e perda do poder familiar}

Vale lembrar que, por determinação do Estatuto da Criança e do Adolescente, em seu art. 22, impõe aos pais "o dever de sustento, guarda e educação dos filhos menores, cabendo-lhes, ainda, no interesse destes, a obrigação de cumprir e fazer cumprir as determinações judiciais".

Inegável que a decisão judicial que determina ou homologa a regulamentação do regime de visitas consiste em determinação judicial, devendo, portanto, ser obedecida pelo genitor guardião, que não poderá obstaculizar o convívio com o genitor descontínuo.

ROBERTO JOÃO ELIAS, comentando o art. 24 do Estatuto da Criança e do Adolescente, afirma que "o descumprimento sem justa causa das obrigações contidas no art. 22 também leva à inibição do poder familiar (pátrio poder). As medidas aplicadas aos pais têm em vista assegurar a proteção integral às crianças e aos adolescentes"189.

Contudo, embora seja inegável que a obstrução do direito de visitas, pelo genitor guardião, configure descumprimento de determinação judicial e seja atentatório aos direitos não apenas do outro genitor, mas, principalmente, aos superiores direitos e interesses dos filhos menores, a aplicação de tais medidas, em sede de regulamentação de direito de visitas, parece-nos perigosa.

Isso porque a decisão judicial que atribuiu a guarda a um dos genitores o fez levando em consideração que tal era o melhor a ser adotado para garantir o melhor interesse do filho. Não faria sentido, pois, inverter a guarda, pois a obstaculização do direito de visitas, embora deva ser obstada e penalizada, não torna automaticamente o

despercebida, razão pela qual afigura-se correta a aplicação da multa. Isso porque já está comprovado que a agravante não cumpre voluntariamente a ordem do Juízo (...)" (sem grifo no original) (TJSP. AgIn

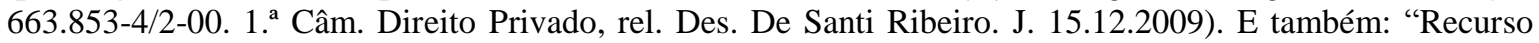
especial. Civil e processual civil. Regulamentação de visitas. Acordo homologado. Descumprimento. Execução. Cabimento.

1 - No campo das visitas, o guardião do menor é devedor de uma obrigação de fazer, ou seja, tem o dever de facilitar a convivência do filho com o visitante nos dias previamente estipulados, devendo se abster de criar obstáculos para o cumprimento do que fora determinado em sentença ou fixado no acordo.

2 - A transação, devidamente homologada em juízo, equipara-se ao julgamento do mérito da lide e tem valor de sentença, dando lugar, em caso de descumprimento, à execução da obrigação de fazer, podendo o juiz inclusive fixar multa a ser paga pelo guardião renitente.

3 - Recurso especial conhecido e provido a fim de determinar o retorno dos autos ao juízo de primeiro grau para regular prosseguimento" (sem grifo no original) (STJ. REsp 701872/DF. 4. ' Turma, rel. Min. Fernando Gonçalves. J. 12.12.2005).

189 ELIAS, Roberto João. Comentários ao Estatuto da Criança e do Adolescente: (Lei n. 8.069, de 13 de julho de 1990). 3. ed. São Paulo: Saraiva, 2008, p. 24-25. 
genitor descontínuo possuidor de condições de exercer a guarda do filho de maneira satisfatória $^{190}$.

Porque uma situação é a inversão da guarda, retirando-a do genitor guardião e transferindo-a ao genitor descontínuo ${ }^{191}$, e outra é a modificação da guarda com a sua atribuição a um terceiro, que reúna as condições necessárias a exercê-la. Se a conduta do genitor guardião for reprovável a ponto de recomendar que perca o poder familiar sobre o filho, cujo reflexo é, dentre outros, a perda da guarda, deverá ser observado o disposto no art. 24 do ECA, que condiciona a suspensão ou perda do poder familiar a procedimento contraditório, nos casos previstos na legislação civil, assim como na hipótese de descumprimento dos deveres e obrigações constantes do art. 22 do Estatuto.

Dessa maneira, dispõe o art. 1.635, V, do Código Civil, que o poder familiar se extingue, dentre outros motivos, por decisão judicial, na forma do art. 1.638. Este dispositivo dispõe, em seu inc. IV, que a reiterada incidência nas faltas do art. 1.637 enseja a decretação da perda do poder familiar. Tais faltas são aquelas que ensejam a suspensão do poder familiar, dentre as quais se encontra a elencada no caput do mencionado art. 1.637, que pune o pai ou a mãe que abusar da sua autoridade, faltando aos deveres a ele inerentes. Assim, como um dos deveres da autoridade parental é, conforme o art. 22 do ECA, o cumprimento das determinações judiciais tomadas em atendimento ao melhor interesse do filho, o seu descumprimento pode, em tese, configurar ato passível de ser sancionado com a suspensão do poder familiar, e, em caso de reiterada incidência em tal descumprimento, culminar com a final perda do poder familiar.

Reitera-se, contudo, que essa não parece ser a melhor solução para os casos de descumprimento do estabelecido no regime de visitas, muito embora, em casos extremos (que configurem, por exemplo, verdadeiros atos de alienação parental), a suspensão e a

\footnotetext{
${ }^{190}$ Nesse sentido, o seguinte acórdão: "Suspensão de visitas e modificação de guarda. Beligerância notória entre os genitores do menor. Estudos psicológico e social não identificaram comportamento inadequado do pai. Mãe habitualmente apresenta obstáculos para a realização das visitas paternas. Interesse do menor impossibilita, por ora, a modificação de guarda. Visitas estipuladas na sentença aptas a sobressair. Em caso de impedimento por parte da genitora, a multa cominada, e ora ampliada, se apresenta adequada, pois visa o efetivo cumprimento do julgado. Apelo da mãe desprovido. Recurso adesivo do pai provido em parte, com

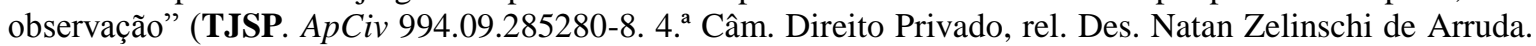
J. 08.04.2010).

${ }^{191}$ Nesse sentido, o seguinte julgado: “Apelação cível. Guarda de menor. Modificação. Demonstrado no autos que a mãe causa maus-tratos físicos e psicológicos à filha menor, de apenas quatro anos de idade, e, de outra parte, que não cumpriu com o acordado quando da separação do casal, estando a impedir o convívio da filha menor com pai e demais irmãos, que residem com o genitor, é de ser concedida a modificação da guarda, nos termos do pedido contido na inicial. Apelo não provido" (TJRS. ApCiv 598242972, 8. ${ }^{\text {a }}$ Câm. Cív., rel. Des. Alzir Felippe Schmitz. J. 13.04.2000).
} 
perda do poder familiar possam ser medidas eficazes na preservação do melhor interesse do filho.

\subsubsection{Indenização por perdas e danos}

$\mathrm{O}$ art. 247 do Código Civil, ao tratar das obrigações de fazer, obriga à indenização por perdas e danos o devedor que recusar a prestação só por ele exequível. No mesmo sentido dispõe o art. 389 do mesmo estatuto, estipulando que, em caso de descumprimento da obrigação, o devedor responderá por perdas e danos. Dessa maneira, sendo impossível a satisfação específica do objeto da obrigação - neste caso a obrigação ao guardião imposta de permitir o contato do genitor descontínuo com o filho, tal qual estabelecido no regime de visitas -, parece juridicamente possível que o genitor descontínuo acione o guardião por perdas e danos.

Vale que o próprio art. $461, \S 11^{\circ}$, do CPC, dispõe que "a obrigação só se converterá em perdas e danos se o autor o requerer ou se impossível a tutela específica ou a obtenção do resultado prático correspondente".

Assim, se se tratar de um dia de visita comum, apesar de o impedimento à visita criado pelo guardião obviamente ser reprovável, não se vê motivo para que se estabeleça uma condenação em perdas e danos, se o tempo durante o qual a visita foi obstado puder ser restituído futuramente.

Imagine-se, contudo, a situação em que o genitor guardião impede a visita do filho ao genitor descontínuo no dia do aniversário deste, ou mesmo no aniversário do próprio menor. Ou ainda que o impedimento do exercício do direito de visita importe em cancelamento de viagem previamente marcada, ou qualquer outra situação semelhante, em que a visita, naquele momento, envolvia uma oportunidade que se quedou perdida.

Nessas hipóteses demonstra-se possível e aconselhável a condenação do genitor guardião em perdas e danos. Não apenas deverá ressarcir ao genitor descontínuo os valores que por ventura tenham sido perdidos em virtude da obstaculização à visita, mas também indenizá-lo pelo dano moral. Afinal, infringir o direito de visitas consiste em violar um dever jurídico imposto por determinação judicial, o que configura claramente o ato ilícito previsto no art. $186^{192}$ do Código Civil, decorrendo disso a obrigação de indenizar prevista no art. $927^{193}$ do mesmo estatuto. Muito embora tal medida tenha, de fato, o condão de

\footnotetext{
${ }^{192}$ Art. 186. "Aquele que, por ação ou omissão voluntária, negligência ou imprudência, violar direito e causar dano a outrem, ainda que exclusivamente moral, comete ato ilícito".

${ }^{193}$ Art. 927. "Aquele que, por ato ilícito (arts. 186 e 187), causar dano a outrem, fica obrigado a repará-lo".
} 
acirrar ainda mais o conflito entre os genitores, se for utilizada com prudência pelo juiz, pode ser uma forma eficaz de estimular o cumprimento do regime de visitas. 


\section{PARTE II - A ALIENAÇÃO PARENTAL COMO FORMA DE ABUSO À CRIANÇA E AO ADOLESCENTE}

\section{NOTA INTRODUTÓRIA - QUANDO O HEROI SE TORNA O VILÃO}

Uma criança, durante uma visitação de duas horas determinada pelo juízo, foi levada a um restaurante por seu pai. Assim que o garoto entrou no carro, disse: "A única razão pela qual estou aqui é porque o juiz disse que eu tenho que vir". O pai o convidou para escolher um restaurante, e ele respondeu: "Escolha qualquer merda de lugar em que você quiser comer, eu não dou a mínima." Ele não disse absolutamente nada a seu pai no caminho do restaurante e, quando lá chegaram, enfiou o nariz no cardápio por aproximadamente 10 minutos, sem dizer uma palavra a seu pai. Ele então se levantou e disse: "Eu tenho que ligar para a minha mãe. Ela me disse para ligar para ter certeza que estou bem". Quando o pai pediu-lhe, educadamente, para ligar rapidamente, ele respondeu: "Eu vou falar com ela por quanto tempo eu quiser, $e$ nada do que eu vou dizer não é da merda da sua conta". Duas vezes durante a refeição ele ligou para a mãe, cada ligação durando entre 10 e 15 minutos. Não surpreendentemente, ele se recusou a comer a refeição elaborada e cara que pediu, dizendo: "Esta comida tem gosto de merda, por que você não leva para casa numa marmita e dá pra sua namorada?". Vemos aqui um bom exemplo da completa ausência de culpa que as crianças que sofrem de SAP muitas vezes apresentam, em associação com os maustratos ao genitor alvo. Este pai, como a maioria dos pais na SAP, vivia um terrível dilema. Esses pais têm a opção de servir como bode expiatório ou afastar-se dos maus tratos, arriscando, assim, a completa perda dos seus filhos ${ }^{194}$ (sem grifo no original).

Com esse trecho, descrito na principal obra do psiquiatra infantil norte-americano

RICHARD A. GARDNER sobre o tema que estudou por mais de vinte anos - e cuja denominação cunhou -, inicia-se a parte final - e tema central - deste trabalho: a Alienação Parental. Os palavrões foram mantidos, sem qualquer tipo de censura, com a

${ }^{194}$ GARDNER, Richard. The parental Alienation Syndrome. $2^{\text {nd }}$ ed. Cresskill, NJ : Creative Therapeutics Inc., 1998, p. 81. Tradução livre de: "One child, during a two-hour court-ordered visitation, was brought to a restaurant by his father. As soon as the child got into the car he said, 'The only reason I'm here is because the judge said I have to come'. The father invited him to select a restaurant, and he responded, 'Choose any shit-hole place you'd like to eat in. I don't give a shit.' He said absolutely nothing to his father during the ride to the restaurant and, when there, poked his nose in the menu for about 10 minutes without saying a word to his father. He then got up and said, 'I've got to call my mother. She told me to call her to make sure that I'm all right'. When the father asked him, politely, to make it quick, he responded, 'I'll speak to her as long as I want, and what I'll be saying is none of your fucking business.' Twice during the meal he called his mother, each call lasting between 10 and 15 minutes. Not surprisingly, he refused to eat the elaborate and expensive meal he ordered, claiming. 'This food tastes like shit; why don't you take it home in a doggie bag and give it to your girlfriend'. We see here a good example of the complete absence of guilt that PAS children often exhibit in association with their maltreatment of the targeted parent. This father, like most PAS parents, suffered a terrible dilemma. Such parents have the choice of serving as a scapegoat or removing themselves from maltreatment and thereby risk the complete loss of their children". 
finalidade de se retratar, às vísceras, um triste - e comum - exemplo do objeto de estudo que esta pesquisa busca trazer ao debate.

Conceituações, definições, problemáticas, explicações, críticas e sugestões serão oportunamente apontadas nos próximos capítulos. Aqui, neste item introdutório, fica a questão à qual se busca responder: o que se pode fazer, através do Direito, para garantir às crianças e adolescentes filhos de pais separados o direito à convivência familiar, como forma de preservação dos seus melhores interesses e de efetivação da sua proteção integral?

Natural será que surjam questionamentos acerca das causas, das razões e das circunstâncias que levam um genitor - pai ou mãe ${ }^{195}$ - a interferir na relação dos seus filhos com o outro. Trata-se de uma prática necessariamente intencional ou é possível que tal interferência ocorra de maneira involuntária? E, de qualquer modo, ainda que não haja intenção, não cumpriria aos genitores que, no interesse dos seus filhos, façam o que estiver ao seu alcance para seu desenvolvimento completo e sadio - o que demanda, inclusive, a participação de ambos os genitores? A partir do momento em que se passa a discutir judicial ou extrajudicialmente - a problemática da convivência familiar entre os filhos e seus pais, com o questionamento acerca da prática do genitor que - intencionalmente ou não - age de forma a dificultar o desenvolvimento ou mesmo o nascimento da relação paterno-filial dos seus filhos com o outro genitor, não se estaria diante de uma situação que eliminaria o caráter involuntário da prática, e que passaria, portanto, a se tornar não mais apenas reprovável, mas também ilegítima e ilegal?

Os pais são os primeiros herois dos seus filhos. É neles que os pequenos se espelham, são eles que, de certa forma, imitam. É claro que os filhos não são cópias dos pais, mas, especialmente nos primeiros anos de vida, seu comportamento, suas atitudes refletem, em diversos graus, a convivência que possuem com seus herois. As crianças absorvem dos seus pais aquilo que seus pais lhes oferecem, sejam características, práticas e hábitos bons ou maus.

Justamente por isso surge o questionamento acerca de como os pais, cônjuges ou não, devam criar seus filhos. O art. 226 da CF/1988, que em seu caput estabelece a proteção especial que deve o Estado dar à família, é claro, em seu $\S 5 .^{\circ}$, que o "planejamento familiar é de livre decisão do casal, competindo ao Estado propiciar

\footnotetext{
${ }^{195}$ A alienação parental pode ser perpetrada, também pelos avós, ou por terceiros que tenham o menor sob sua autoridade, guarda ou vigilância, conforme dispõe o art. 2. ${ }^{\circ}$ da Lei 12.318/2010, a Lei da Alienação Parental.
} 
recursos educacionais e científicos para o exercício desse direito, vedada qualquer forma coercitiva por parte de instituições oficiais ou privadas" (sem grifo no original). Podese inferir, portanto, que é vedado ao Estado impor ao indivíduo uma eventual "melhor forma" de criar e educar os filhos.

É importante frisar que não existe escola que ensine a ser pai e mãe. Não se ensina a maternidade e a paternidade, simplesmente porque as pessoas aprendem a ser pais sendo filhos. É completamente natural - aliás, é da essência da organicidade familiar - que comportamentos dos pais sejam reproduzidos por seus filhos quando estes também forem pais, com as naturais transformações e adaptações absorvidas do convívio social, bem como da própria personalidade e das experiências pessoais de cada indivíduo. Tudo isso contribui na formação dos filhos, futuros pais, e é assim que as famílias - e a sociedade se desenvolvem.

Não se vislumbra, dessa forma, qualquer espécie de interferência indevida do Estado na forma como os pais criam seus filhos, por mais reprováveis que certas formas e certos trajetos de criação possam se mostrar. Se os pais não ensinam, ou ensinam deficitariamente seus filhos a serem, por exemplo, educados, honestos e íntegros, não cabe ao Estado, nem a ninguém, tomar qualquer providência a respeito disso, pois a criação dos filhos, inserta no planejamento familiar, compete, regra geral, exclusivamente aos seus pais.

Mas existem limites, e cumpre identificar em que momento a criação dos filhos ultrapassa a linha divisória entre a liberdade de planejamento familiar e as imposições legais que protegem a família - por vezes dos seus próprios membros.

Destaca-se, de plano, que aquilo que é direito dos filhos, será um dever dos pais. E o caput do art. 227 da CF/1988 estabelece expressamente:

É dever da família, da sociedade e do Estado assegurar à criança, ao adolescente e ao jovem, com absoluta prioridade, o direito à vida, à saúde, à alimentação, à educação, ao lazer, à profissionalização, à cultura, à dignidade, ao respeito, à liberdade e à convivência familiar e comunitária, além de colocá-los a salvo de toda forma de negligência, discriminação, exploração, violência, crueldade e opressão.

Não será possível, portanto, sob qualquer prisma, embasar na liberdade de planejamento familiar, e no fato de que a criação dos filhos, desta ou daquela forma, compete única e exclusivamente aos pais, eventual violação ao direito que às crianças e adolescentes assiste de ter garantida a convivência com sua família, principalmente com 
seus genitores. É direito constitucionalmente assegurado, com absoluta prioridade, oponível contra quem quer que seja, em quaisquer hipóteses em que haja violação.

E, adianta-se, a alienação parental consiste em nada menos do que na obstrução desse direito à convivência familiar, o que significa, portanto, que a alienação parental conforme se demonstrará nos próximos capítulos com mais detalhes - importa em verdadeira violação ao dever que aos pais compete, conforme determinado pela Constituição, de assegurar à criança, ao adolescente e ao jovem, com absoluta prioridade, o direito à convivência familiar.

Dessa forma, relevante destacar que o constituinte, bem como o legislador infraconstitucional, estabeleceu não uma forma de interferência na liberdade de planejamento familiar, mas sim um dever, aos pais imposto, de agir, na educação e na criação dos seus filhos, de forma a sempre preservar os melhores interesses destes.

Os pais, portanto, devem exercer a autoridade parental com cuidado. Cuidado para não prejudicar os próprios filhos durante o seu desenvolvimento, em que a atuação dos pais serve de norte, de guia à formação da personalidade dos filhos. As famílias devem ser, por sua natureza, uma estrutura de cuidado: cuidado do grupo e de cada membro, unitariamente, nas relações do grupo ${ }^{196}$. E a violação a esse verdadeiro dever de cuidado pode perfeitamente ensejar sanções por parte do Estado-juiz.

É importante ressaltar, mais uma vez, que não se advoga, aqui, a interferência estatal na criação dos filhos, porque não é papel do Estado tomar nas mãos aquilo que naturalmente compete às pessoas que geraram os filhos, ou àquelas que os substituem na mesma posição: os pais. Ao Estado cumpre apenas regular as relações entre indivíduos já formados - e formados das maneiras mais diversas, tão diversas quanto as são as famílias em que crianças e adolescentes se desenvolvem e se tornam adultos -, protegendo, contudo, os meios adequados a essa formação. O Estado não pode dizer aos pais o que devem fazer no que se refere à forma como criam seus filhos - mas pode dizer-lhes o que não devem fazer.

Nesse sentido, TÂNIA DA SILVA PEREIRA lembra que autorizam a intervenção estatal na relação paterno-filial os casos de abuso praticado pelos pais ou responsáveis, referindo-se à hipótese de "abuso de direito". Acrescenta ainda que "o abuso da autoridade e a falta aos deveres inerentes à autoridade parental autorizam o Juiz a adotar medida que lhe pareça reclamada pela segurança do filho e seus haveres, podendo inclusive suspender

${ }^{196}$ GUAZELLI, Mônica. A falsa denúncia de abuso sexual. In: DIAS, Maria Berenice (coord.). Incesto e Alienação Parental - realidades que a Justiça insiste em não ver. São Paulo: Ed. RT, 2007, p. 113. 
suas prerrogativas" ${ }^{" 197}$. MARIA BERENICE DIAS, em posicionamento similar, advoga que "a lei obriga e responsabiliza os pais no que toca aos cuidados com os filhos. A ausência desses cuidados, o abandono moral, viola a integridade psicofísica dos filhos, bem como o princípio da solidariedade familiar, valores protegidos constitucionalmente" ${ }^{\text {"198 }}$. Assim, conclui TÂNIA DA SILVA PEREIRA que:

Adotada pelo Brasil a Doutrina Jurídica da Proteção Integral, temos presente que o "cuidado" é a base dos direitos fundamentais da criança e do adolescente indicados no art. 227, CF: ele está presente no direito à vida, à saúde, à alimentação, à educação, ao lazer, à profissionalização, à cultura, à dignidade, ao respeito, à liberdade e à convivência familiar e comunitária; outrossim, toda forma de negligência, discriminação, exploração, violência, crueldade e opressão reflete o descaso, a falta de cuidado, o abandono $^{199}$ (sem grifo no original).

Pode-se entrever, dessa forma, que do rol de deveres entrelaçados no feixe que compõe o múnus da autoridade parental (poder familiar), emerge como principal responsabilidade parental o dever de cuidado, que consiste não numa estatização da criação dos filhos - através de qualquer sorte de guia oficial que imponha aos pais que criem sua prole desta ou daquela forma, mas sim num dever de cautela, de ponderação, a exigir dos genitores que ajam de forma a observar, sempre, com a prioridade absoluta determinada pela Constituição, o melhor interesse dos seus filhos.

E não é preciso se debruçar sobre qualquer estudo de profundidade para se perceber que a obstrução, o impedimento do direito de convivência familiar, além de violar um direito que compete a ambos os genitores de possuírem e desenvolverem estreitos laços afetivos com seus filhos, indiscutivelmente não preserva os melhores interesses dos filhos, dentro da sua proteção integral.

No esteio dessas considerações, os capítulos seguintes, integrantes da parte final desta pesquisa, buscarão traçar um panorama da alienação parental, inclusive em sua mais destrutiva forma, quando se observa a instalação da correspectiva síndrome, na terminologia que é adotada pelos estudiosos do assunto no campo da saúde mental.

Forçoso ressaltar que, muito embora esta pesquisa seja inescapavelmente permeada pela interdisciplinaridade que o próprio tema exige, trata-se de um estudo jurídico acerca

\footnotetext{
${ }^{197}$ PEREIRA, Tânia da Silva. Direito da criança e do adolescente - uma proposta interdisciplinar. 2 . ed. rev. e atual. Rio de Janeiro: Renovar, 2008, p. 69.

${ }^{198}$ DIAS, Maria Berenice. Manual de Direito das Famílias. 8. ed. rev. e atual. São Paulo: Ed. RT, 2011, p. 461.

${ }^{199}$ PEREIRA, Tânia da Silva. Direito da criança e do adolescente - uma proposta interdisciplinar. 2 . ed. rev. e atual. Rio de Janeiro: Renovar, 2008, p. 73.
} 
de uma questão que aborda aspectos da saúde mental. Discussões acerca dos aspectos psiquiátricos e psicológicos da alienação parental, aqui, serão tratadas de forma meramente incidental, trazendo sempre as formulações de profissionais da área da saúde mental, com formação específica e, assim, qualificação técnica para tratar dos aspectos estruturais da alienação parental - e da sua síndrome.

Dessa forma, a este trabalho resta o objetivo de, em conjunto com as análises das obras específicas acerca da alienação parental - que trazem suas origens, suas formas de desenvolvimento, suas consequências, e, por fim, as formas de prevenção e tratamento -, averiguar quais as implicações que essa forma de desrespeito ao direito de convivência familiar produz na esfera jurídica, posto que se trata de um fenômeno que ocorre preponderantemente no âmbito das separações e dos divórcios em que existe disputa judicial pela guarda dos filhos. Trata-se de um momento muito delicado, tenso e estressante para todas as partes envolvidas, e é natural que conflitos se desenvolvam. Contudo, se não forem oportuna e corretamente contidos, podem resultar em verdadeiras tragédias familiares, muitas vezes com prejuízos irrecuperáveis e danos irreversíveis. 


\section{ALIENAÇÃO PARENTAL E SÍNDROME DA ALIENAÇÃO PARENTAL}

\subsection{Histórico e conceito}

A alienação parental provavelmente existe desde que as separações conjugais (em sentido amplo) existem. É no florescer do conflito que rompe a relação do casal conjugal que a alienação parental encontra solo fértil para se desenvolver. Assim, desde que se passou a admitir a dissolução do casamento, o palco para a ocorrência de conflitos entre os ex-cônjuges possui espaço, também, para os filhos advindos da união que se desfaz. O crescente número de separações - especialmente as litigiosas - viu-se acompanhado também do alvorecer de disputas pela guarda dos filhos.

Além disso, durante algum tempo verificou-se a preferência materna na atribuição da guarda dos filhos após o rompimento do casal, no que se chamou de presunção da tenra idade (tender-years presumption), em que:

Os tribunais passaram a funcionar sob a presunção de que havia certos benefícios psicológicos que a criança poderia obter da sua mãe, e que não poderiam ser igualmente obtidos do pai. A noção de retirar um infante em fase de amamentação de sua mãe tornouse de certa forma imprudente e "errada". Assim, as mães começaram a receber a custódia dos filhos pequenos. Mas quando as crianças alcançavam a idade de três ou quatro anos (idade em que a amamentação costumava cessar no século 19), consideravase que já haviam recebido das mães tudo aquilo de que necessitavam, e eram então transferidas à guarda dos pais, seu "genitor de direito" 200 .

Gardner anota, ainda que, no início do século XX, houve alterações legislativas e a guarda deixou de ser atribuída automaticamente aos pais. Começou-se a ser levado em consideração o fator capacidade parental, independentemente do sexo, colocando o pai e a mãe em pé de igualdade quando da atribuição da guarda dos filhos menores ${ }^{201}$.

Com isso, e em aliança aos movimentos de independência e às lutas pelos direitos das mulheres, operou-se uma inversão que pode ser observada até os dias de hoje: na

\footnotetext{
${ }^{200}$ GARDNER, Richard. The parental Alienation Syndrome. $2^{\text {nd }}$ ed. Cresskill, NJ : Creative Therapeutics Inc., 1998, p. 28. Tradução livre de: "The courts began to work under the presumption that there were certain psychological benefits that the child could gain from its mother that were not to be so readily obtained from its father. The notion of wresting a suckling infant from its mother's breast came to be viewed as somehow injudicious and 'wrong'. Accordingly, mothers began to be given custody of their infant children. Bur when the children reached the age of three or four (the age at which breast-feeding was usually discontinued in the $19^{\text {th }}$ century), they were considered to have gained all that they needed from their mother, and they were transferred to their father, their 'rightful and just' parent".

${ }^{201}$ GARDNER, Richard. The parental Alienation Syndrome. $2^{\text {nd }}$ ed. Cresskill, NJ : Creative Therapeutics Inc., 1998, p. 29.
} 
maioria dos casos em que se verifica a guarda unilateral - consensual ou litigiosa - dos filhos menores, ela geralmente é atribuída à mãe. Vale lembrar, ainda, que o próprio Código Civil de 1916 - que vigorou até janeiro de 2003 - permitia que se levasse em conta, na atribuição da guarda dos filhos, a conduta do cônjuge considerado culpado pela separação ou divórcio (art. 326).

Aos poucos, a culpa pelo fim do casamento passou a figurar em segundo plano, levando-se em consideração que, ainda que tenha havido uma atitude concreta de uma das partes a ensejar, objetivamente, a deflagração do processo de dissolução da união, havia muito mais elementos, muitas vezes atribuíveis a ambos os cônjuges, que colaboraram para a falência da relação conjugal.

Relativizou-se a importância da culpa pelo fim do casamento não apenas em questões referentes ao pagamento de pensão alimentícia e à utilização do sobrenome do cônjuge inocente: a guarda dos filhos foi dissociada da culpa pelo fim do relacionamento conjugal, para se passar a avaliar qual dos ex-cônjuges possuiria mais condições de proporcionar a melhor criação aos filhos menores.

Ainda assim verificou-se, por algum tempo - e verifica-se até hoje - a preferência materna na atribuição da guarda, por motivos que não exigem maior detalhamento no presente estudo. Relevante, mesmo, é o fato de que nos últimos anos passou a haver uma revolta, pelos pais, contra a presunção da tenra idade. É inegável que, se por um lado houve expressivo avanço das mulheres rumo à sua independência, em muitos casos passando a suplantar os homens em posições que antigamente sequer se cogitava pudessem ser assumidas por mulheres, por outro ângulo também se observou a adaptação masculina ao papel não apenas de provedor do lar, mas também de participação nas tarefas e funções que anteriormente eram reservadas às mulheres. Se os pais não poderiam ser automaticamente preferidos quanto ao exercício da guarda, o oposto seria igualmente válido. Seria necessário avaliar, in casu, qual dos genitores - se não ambos - possuiria melhores condições de exercer a guarda dos filhos.

E importa destacar que a condição financeira é irrelevante para a atribuição da guarda a este ou aquele genitor: importam, mesmo, os vínculos afetivos que os filhos mantêm, bem como as possibilidades objetivas do genitor de exercer a guarda diuturnamente, provendo as necessidades dos filhos, tais como acompanhamento escolar, tempo disponível para manter uma saudável convivência com as crianças, e, é claro, estabilidade emocional para efetivar todas as medidas necessárias ao bom exercício da guarda. 
Foi assim que se passou da presunção da tenra idade para a doutrina do melhor interesse das crianças e dos adolescentes. Com essa desvinculação da guarda dos filhos a uma preferência pelo pai ou pela mãe, observou-se o aumento nas disputas entre os genitores pela guarda. E é exatamente essa disputa - muitas vezes motivada não pela real vontade dos genitores de ter os filhos junto de si, mas por motivos de vingança um contra o outro - que permitirá, com muito mais força, a ocorrência da alienação parental.

Isso não quer dizer, obviamente, que toda separação que envolva filhos menores (e, portanto, sob a autoridade parental do casal) vá, necessariamente, assistir à eclosão de tal fenômeno. Contudo, conforme será possível perceber nas páginas adiante, não são incomuns os casos em que, de separações conflituosas, decorra o surgimento do fenômeno alienador, em maior ou menor grau.

Assim, melhor será apontar, desde logo, a conceituação da síndrome da alienação parental, nas palavras do próprio criador do termo, o psiquiatra infantil da Universidade de Colúmbia, Dr. RICHARD A. GARDNER:

A síndrome da alienação parental (SAP) é um distúrbio que emerge primordialmente no contexto da disputa pela guarda de filhos. Sua primeira manifestação é a campanha de denegrimento da criança contra um genitor, uma campanha que não possui justificativa. Ela resulta da combinação das doutrinações de um genitor programador (lavagem cerebral) e das próprias contribuições da criança para o vilipêndio do genitor-alvo. Quando um real abuso ou negligência parental está presente, a animosidade da criança pode ser justificada, e, portanto, a síndrome da alienação parental como explicação para a hostilidade da criança não é aplicável $^{202}$.

Baseado no trabalho de Gardner, e traçando um breve panorama do surgimento e do crescimento da incidência da síndrome da alienação parental nas disputas pela guarda de filhos, nos Estados Unidos, o psicólogo forense DEIRDRE CONWAY RAND aponta que:

As tendências identificadas por Gardner e outros são o resultado de importantes mudanças sociais que começaram a criar raízes e florescer em meados dos anos 1970. O tratamento jurídico do divórcio e da custódia da criança deslocou-se da preferência pelas mães para uma guarda exclusiva, e da 'presunção da tenra idade' para a preferência pela guarda conjunta e o 'melhor interesse da

202 GARDNER, Richard. The parental Alienation Syndrome. $2^{\text {nd }}$ ed. Cresskill, NJ : Creative Therapeutics Inc., 1998, p. xx. Tradução livre de: "The parental alienation syndrome (PAS) is a disorder that arises primarily in the context of child-custody disputes. Its primary manifestation is the child's campaign of denigration against a parent, a campaign that has no justification. It results from de combination of a programming (brainwashing) parent's indoctrinations and the child's own contributions to the vilification of the target parent. When true parental abuse and/or neglect is present the child's animosity may be justified, and so the parental alienation syndrome explanation for the child's hostility is not applicable." 
criança'. Isso forneceu aos pais que se divorciavam mais opções legais para cuidarem de seus filhos, e aumentou a quantidade e intensidade das disputas em divórcios, ao passo que os genitores veementemente discordavam ante o número de disposições de custódia então disponíveis. No fim dos anos 1970, a crescente preocupação com a programação parental das crianças para influenciar o resultado de disputas levou a Seção de Direito de Família da Associação Americana de Advogados a encomendar um estudo em larga escala do problema ${ }^{203}$.

JORGE TRINDADE, em capítulo dedicado à temática, busca conceituar a

Síndrome de Alienação Parental com sendo um

transtorno psicológico que se caracteriza por um conjunto de sintomas pelos quais um genitor, denominado cônjuge alienador, transforma a consciência de seus filhos, mediante diferentes formas e estratégias de atuação, com o objetivo de impedir, obstaculizar ou destruir seus vínculos com o outro genitor, denominado cônjuge alienado, sem que existam motivos reais que justifiquem essa condição. Em outras palavras, consiste num processo de programar uma criança para que odeie um de seus genitores sem justificativa, de modo que a própria criança ingressa na trajetória de desmoralização desse mesmo genitor. Dessa maneira, podemos dizer que o alienador "educa" os filhos no ódio contra o outro genitor, seu pai ou sua mãe, até conseguir que eles, de modo próprio, levem a cabo esse rechaço ${ }^{204}$.

Por seu turno, WILLIAM BERNET, professor de psiquiatria da Vanderbilt

University School of Medicine, nos Estados Unidos, também centrado nos estudos de

Gardner, define a SAP como sendo um:

perturbador fenômeno psicológico em que a criança - geralmente uma cujos pais estão envolvidos num divórcio hostil - vem a se alinhar fortemente a um dos genitores e rejeita um relacionamento com o outro sem justificativa legítima. As características clínicas da SAP incluem: uma campanha de difamação; racionalizações fracas, frívolas e absurdas para a difamação; falta de ambivalência; fenômeno do pensador-independente; apoio reflexivo a um genitor contra o outro; ausência de culpa na exploração do genitor-alvo;

\footnotetext{
${ }^{203}$ RAND, Deirdre Conway. The Spectrum of Parental Alienation Syndrome, Part I. American Journal of Forensic Psychology, 15(3), 23-52, 1997. Disponível em: http://www.robin.no/ dadwatch/pasdir/rand01.html>. Acesso em 11 de outubro de 2011. Tradução livre de: "The trends identified by Gardner and others are the result of important social changes which began to take root and flower around the mid 1970s. The legal treatment of divorce and child custody shifted from the preference for mothers to have sole custody and the 'tender years presumption' to the preference for joint custody and 'best interests of the child'. This gave divorce fathers more legal options for parenting their children and increased the quantity and intensity of divorce disputes as parents vehemently disagreed over the numerous custodial arrangements now possible. By the late 1970s, rising concern about parental programming of children to influence the outcome of disputes led the American Bar Association Section of Family Law to commission a large scale study of the problem".

${ }^{204}$ TRINDADE, Jorge. Síndrome da Alienação Parental. In: DIAS, Maria Berenice (coord.). Incesto e Alienação Parental - realidades que a Justiça insiste em não ver. São Paulo: RT, 2007, p. 102.
} 
presença de cenários emprestados; e extensão da animosidade à família do genitor-alvo ${ }^{205}$.

JANELLE BURRILL lembra que a síndrome da alienação parental normalmente se desenvolve no seio do conflito familiar:

A SAP é um distúrbio que surge quase que exclusivamente no contexto de disputas de custódia dos filhos. Ele inclui um conjunto de sintomas que geralmente aparecem juntos - conjunto que permite a designação de síndrome. Tais sintomas incluem a difamação do genitor alienado pelo genitor alienante, a programação da criança, bem como cenários próprios da criança. Aparecem juntos sob a forma de síndrome. O fenômeno da SAP ocorre no contexto de um sistema familiar altamente conflituoso que é composto de uma criança, um genitor alienador e um genitor alienado, que é vitimado por este processo. Na verdade, a criança é a vítima real. A criança frequentemente torna-se alienada do genitor alienado pelo genitor alienador. (...) As características e comportamentos dos genitores alienadores, dos genitores alienados, das crianças, e os critérios específicos para determinar a SAP se prestam muito bem a identificá-la como uma "síndrome". Em contraste com a SAP, a AP é um termo muito geral e não é uma síndrome. (...) O diagnóstico da SAP é baseado nos sintomas da criança, mas o problema é sempre um problema familiar em que em um dos genitores programa a criança, o outro genitor sofre a alienação, e as crianças exibem certos comportamentos. SAP não é uma animosidade que a criança possui contra um genitor que realmente cometeu abuso contra ela. Não é considerada se o genitor alienado é negligentes e/ou abusivo. Em vez disso, nos casos típicos, o alienado seria considerado pela maioria dos profissionais como tendo sido um genitor normal, amoroso ou, na pior das hipóteses, ter exibido mínimas deficiências de capacidade parental $^{206}$.

${ }^{205}$ BERNET, William. Sexual abuse allegations in the context of child custody disputes. In: GARDNER, Richard A.; LORANDOS, Demosthenes; SAUBER, S. Richard (org.) The International Handbook of Parental Alienation Syndrome. 2nd ed. Springfield, IL : Charles C Thomas Publisher LTD, 2006, p. 244. Tradução livre de: "PAS is a disturbing psychological phenomenon in which a child - usually one whose parents are engaged in a hostile divorce - comes to ally himself of herself strongly with one parent and rejects a relationship with the other parent without legitimate justification. The clinical features of PAS include: a campaign of denigration; weak, frivolous and absurd rationalizations for the deprecation; lack of ambivalence; independent-thinker phenomenon; reflexive support of one parent against the other; absence of guilt over exploitation of the targeted parent; presence of borrowed scenarios; and spread of the animosity to the extended family of the targeted parent".

${ }^{206}$ BURRILL, Janelle. Reluctance to verify PAS as a legitimate syndrome. In: GARDNER, Richard A.; LORANDOS, Demosthenes; SAUBER, S. Richard (org.) The International Handbook of Parental Alienation Syndrome. 2nd ed. Springfield, IL : Charles C Thomas Publisher LTD, 2006, p. 324. Tradução livre de: "PAS is a disorder that arises almost exclusively in the context of child custody disputes. It includes a cluster of symptoms that typically appear together - a cluster that warrants the designation syndrome. These symptoms include the alienating parent's denigration of the alienated parent and the programming of the child, and the child's own scenarios. These appear together to the form of syndrome. The phenomenon of PAS occurs in the context of a highly conflicted family system that is composed of a child, an alienating parent, and an alienated parent, who is victimized by this process. Actually, the child is the real victim. The child frequently becomes estranged from the alienated parent by the alienating parent. (...) The characteristics and behaviors of the alienating parents, the alienated parents, the children, and specific criteria for determining PAS lend 
No cenário nacional poucos autores trataram do tema. FÁBIO VIEIRA FIGUEIREDO e GEORGIOS ALEXANDRIDIS, buscando delimitar uma definição do tema, ao qual se referem como fenômeno da alienação parental, afirmam que:

Muitas vezes, um dos genitores implanta na pessoa do filho falsas ideias e memórias com relação ao outro, gerando, assim, uma busca em afastá-lo do convívio social, como forma de puni-lo, de se vingar, ou mesmo com o intuito falso de supostamente proteger o filho menor como se o mal causado ao genitor fosse se repetir ao filho ${ }^{207}$.

DOUGLAS PHILLIPS FREITAS e GRACIELA PELLIZZARO, por sua vez, em comentários sobre a Lei da Alienação Parental (12.318/2010), trazem um conceito que parece incompleto do que vem a ser a Síndrome da Alienação Parental (SAP):

Trata-se de um transtorno psicológico caracterizado por um conjunto sintomático pelo qual um genitor, denominado cônjuge alienador, modifica a consciência de seu filho, por meio de estratégias de atuação e malícia (mesmo que inconscientemente), com o objetivo de impedir, obstaculizar ou destruir seus vínculos com o outro genitor, denominado cônjuge alienado. Geralmente não há motivos reais que justifiquem essa condição. É uma programação sistemática promovida pelo genitor alienador para que a criança odeie, despreze ou tema o genitor alienado, sem justificativa real $^{208}$.

E seguem complementando que:

Essa conduta, intencional ou não, desencadeia uma campanha de modificação nas emoções do alienador e da criança, na sequência, que a faz produzir um sistema de cumplicidade e compreensão da conduta do alienante, ora justificando, ora praticando (a criança) atos que visam a (sic) aprovação do alienante, que joga e chantageia sentimentalmente o menor ${ }^{209}$.

O equívoco reside no fato de que, conforme descrita por Gardner, a Síndrome da Alienação Parental não consiste apenas nos atos do genitor alienador de forma a

themselves very well to be identified as a 'syndrome'. In contrast to PAS, PA is a very general term and is not a syndrome. (...) The PAS diagnosis is based on the symptoms of the child, but the problem is always a familial problem in that in each case one parent is programming the child, one parent is alienated against, and the children exhibit certain behaviors. PAS is not animosity that a child harbors against a parent who has actually abused him or her. It is never considered if the alienated parent is found neglectful and/or abusive. Rather, in typical cases, the alienated parent would be considered by most practitioners to have been a normal, loving parent or, at worst, to have exhibited minimal impairments in parenting capacity".

207 FIGUEIREDO, Fábio Vieira; ALEXANDRIDIS, Georgios. Alienação parental: aspectos materiais e processuais da Lei n. 12.318, de 26-8-2010. São Paulo: Saraiva, 2011, p. 43-44.

208 FREITAS, Douglas Phillips; PELLIZZARO, Graciela. Alienação parental: comentários à Lei 12.318/2010. Rio de Janeiro: Ed. Forense, 2011, p. 20.

209 FREITAS, Douglas Phillips; PELLIZZARO, Graciela. Alienação parental: comentários à Lei 12.318/2010. Rio de Janeiro: Ed. Forense, 2011, p. 30. 
desconstruir o afeto e minar a relação que seu filho possui com o outro genitor. Tal conduta consiste, de fato, em uma forma de alienação parental, uma prática que pode ser efetivada de diversas maneiras, e que pode possuir como consequência a instalação da síndrome da alienação parental.

\subsection{Alienação parental e síndrome da alienação parental}

O próprio Gardner, que serviu como psiquiatra forense em inúmeros casos de disputa de guarda, aponta a diferença existente entre alienação parental e síndrome da alienação parental, dada a comum confusão que se faz entre os termos:

A alienação parental (AP) é um termo geral que abarca qualquer situação em que uma criança possa ser alienada de um genitor. Pode ser causada por abuso parental físico, verbal, emocional, mental, sexual, abandono e negligência. Adolescentes, como atos de rebelião, podem se tornar alienados de um genitor. (...) Uma criança também pode ser programada por um genitor para ser alienada em relação ao outro. Essa categoria específica de alienação parental é genericamente mencionada como síndrome da alienação parental $^{210}$.

Ainda buscando estabelecer a diferenciação entre alienação parental e síndrome da alienação parental, Gardner reforça, mais detalhadamente:

Há aqueles que utilizam o termo alienação parental em vez de síndrome de alienação parental. Geralmente se trata de indivíduos que sabem da existência da síndrome de alienação parental, mas querem evitar utilizá-la, pois pode ser considerado em alguns círculos como sendo "politicamente incorreto". Mas estão, basicamente, descrevendo a mesma entidade clínica. (...) Infelizmente, a substituição do termo alienação parental por síndrome de alienação parental apenas resulta em confusão. Alienação parental é um termo mais geral, enquanto síndrome de alienação parental é um subtipo muito específico de alienação parental. A alienação parental possui muitas causas, por exemplo, a negligência parental, o abuso (físico, emocional e sexual), abandono, e outros comportamentos parentais alienadores. A síndrome de alienação parental é uma subcategoria específica de alienação parental, que resulta de uma combinação de programação

${ }^{210}$ GARDNER, Richard. Introduction. In: GARDNER, Richard A.; LORANDOS, Demosthenes; SAUBER, S. Richard (org.) The International Handbook of Parental Alienation Syndrome. Springfield: Charles C. Thomas Publisher Ltd., 2006, p. 6. Tradução livre de: "Parental alienation (PA) is a general term that covers any situation in which a child can be alienated from a parent. It can be caused by parental physical abuse, verbal abuse, emotional abuse, mental abuse, sexual abuse, abandonment, and neglect. Adolescents, as an act of rebellion, may become alienated from a parent. (...) A child can also be programmed by one parent to be alienated from another. That particular category of parental alienation is generally referred to as parental alienation syndrome". 
parental e contribuições da própria criança, e é encontrado quase que exclusivamente no contexto de disputas pela custódia dos filhos. É esta combinação particular que justifica a designação síndrome de alienação parental ${ }^{211}$.

DOUGLAS DARNALL enfatiza tais dissemelhanças, apontando que:

Existe uma diferença entre alienação parental e síndrome da alienação parental, apesar de os sintomas ou aquilo que é observado na criança possam ser similares. A distinção entre as duas é que a alienação parental se foca em como o genitor alienador se comporta em relação à criança e ao genitor alienado. Os sintomas da síndrome da alienação parental descrevem os comportamentos e as atitudes da criança em relação ao genitoralvo depois que a criança foi efetivamente programada e severamente alienada do genitor-alvo.

(...)

A alienação parental (AP) foca-se mais no comportamento do genitor do que no papel da criança na difamação do genitor vitimizado. Assim, a alienação pode ocorrer muito antes do ódio do genitor permear as crenças da criança acerca do genitor vitimizado. Essa definição de alienação parental é necessária para que os pais reconheçam o rico que eles correm de inconscientemente cair num padrão de alienação. Ao tempo em que os filhos vierem a concordar com o genitor alienador, geralmente será tarde demais para prevenir danos significativos ${ }^{212}$.

Percebe-se, portanto, que, muito embora sejam dois conceitos complementares, alienação parental e síndrome da alienação parental não se confundem ${ }^{213}$. Conforme

${ }^{211}$ GARDNER, Richard. The parental Alienation Syndrome. $2^{\text {nd }}$ ed. Cresskill, NJ : Creative Therapeutics Inc., 1998, p. xxviii. Tradução livre de: "There are some who use the term parental alienation instead of parental alienation syndrome. Generally, these are individuals who know of the existence of the parental alienation syndrome but want to avoid using it because it may be considered in some circles to be 'politically incorrect'. But they are basically describing the same clinical entity. (...) Unfortunately, the substitution of the term parental alienation for parental alienation syndrome can only result in confusion. Parental alienation is a more general term, whereas parental alienation syndrome is a very specific subtype of parental alienation. Parental alienation has many causes, e.g., parental neglect, abuse (physical, emotional, and sexual), abandonment, and other alienating parental behaviors. The parental alienation syndrome is a specific subcategory of parental alienation that results from a combination of parental programming and the child's own contributions, and it is almost exclusively seen in the context of child-custody disputes. It is this particular combination that warrants the designation parental alienation syndrome."

212 DARNALL, Douglas. Divorce casualties: protecting your children from parental alienation. Lanham, MD, USA: Taylor Trade Publishing, 1998, p. 3-5. Tradução livre de: "There is a difference between parental alienation and parental alienation syndrome, though the symptoms or what is observed in the children can be similar. The distinction between the two is that parental alienation focuses on how the alienating parent behaves toward the children and the targeted parent. Parental alienation syndrome describe the child's behaviors and attitudes toward the targeted parent after the child has been effectively programmed and severely alienated from the targeted parent. (...) Parental alienation (PA) focuses more on the parent's behavior than on the child's role in degrading the victimized parent. Thus, alienation can occur well before the parent's hatred permeates the child's beliefs about the victimized parent. This definition of parental alienation is necessary if parents are to recognize the risk they have for unconsciously falling into a pattern of alienation. By the time the children have come to agree with the alienating parent, it is usually too late to prevent significant damage".

${ }^{213}$ Gardner aponta, ainda, para a diferenciação entre "lavagem cerebral" e "síndrome da alienação parental", apontando que "Há muitos que utilizam o termo síndrome da alienação parental como sinônimo de lavagem 
restou demonstrado pelos apontamentos de Gardner e de Darnall, a alienação parental é uma prática levada a cabo pelo genitor alienador, por vezes até mesmo de forma inconsciente, que possui como principal consequência a interferência na relação afetiva paterno-filial entre o filho e o genitor alienado. Pode ser que tal consequência não venha a se efetivar, a depender de diversos fatores, dentre os quais o grau de consciência que o filho possui do conflito entre os seus genitores, bem como a eficiência de intervenções externas - judiciais ou não - a coibir a prática da alienação parental, que pode se dar através de inúmeras maneiras, como o impedimento ao exercício do direito de visitas, a injusta e insidiosa vilificação do outro genitor, etc.

Por seu turno, a síndrome da alienação parental decorre não apenas da prática da alienação parental pelo genitor alienador: trata-se de uma complexa situação em que a alienação já foi - e continua sendo - perpetrada pelo alienador e absorvida pela criança, que, em certo ponto, passa a contribuir para a difamação do genitor alienado, e ingressa

cerebral parental ou de programação. Aqueles que o fazem deixaram escapar um ponto extremamente importante quanto à etiologia, às manifestações, e até mesmo o tratamento da SAP. O transtorno se refere a uma situação em que a programação dos pais é combinada com cenários criados pela própria criança para a difamação do alegadamente odiado genitor. Estivéssemos lidando aqui simplesmente com a doutrinação parental, eu provavelmente teria utilizado o termo lavagem cerebral ou programação. Como o distúrbio envolve a combinação acima, decidi um novo termo se justificaria, um termo que englobaria os dois fatores contributivos. Foram as contribuições da própria criança que me levaram à compreensão da etiologia e patogênese deste distúrbio. (...) Infelizmente, o termo SAP é por vezes utilizado para se referir à animosidade que uma criança pode apresentar contra um pai que realmente cometeu abuso, especialmente durante um período prolongado. O termo SAP tem sido aplicado nas principais categorias de abuso dos pais, ou seja, físico, sexual e emocional. Tal aplicação indica um mal-entendido da SAP. O termo SAP é aplicável somente quando o genitor-alvo não exibiu nada próximo do grau de comportamento alienante que possa justificar a campanha de difamação perpetrada pela criança. Em vez disso, nos casos típicos o genitor seria considerado pela maioria dos examinadores como tendo praticado uma paternidade amorosa normal, ou, na pior das hipóteses, ter exibido mínimas deficiências de capacidade parental. É o exagero das pequenas fraquezas e deficiências que formam a marca da SAP". GARDNER, Richard. The parental Alienation Syndrome. $2^{\text {nd }}$ ed. Cresskill, NJ : Creative Therapeutics Inc., 1998, p. 73-74. Tradução livre de: "There are many who use the term parental alienation syndrome as synonymous with parental brainwashing or programming. Those who do this have missed an extremely important point regarding the etiology, manifestations, and even the treatment of the PAS. The disorder refers to a situation in which the parental programming is combined with the child's own scenarios of denigration of the allegedly hated parent. Were we to be dealing here simply with parental indoctrination, I probably would have utilized the term brainwashing or programming. Because the disorder involves the aforementioned combination, I decided a new term was warranted, a term that would encompass both contributory factors. It was the child's contribution that led me to my understanding of the etiology and pathogenesis of this disorder. (...) Unfortunately, the term PAS is sometimes used to refer to the animosity that a child may harbor against a parent who has actually abused the child, especially over an extended period. The term PAS has been used to apply to the major categories of parental abuse, namely, physical, sexual, and emotional. Such application indicates a misunderstanding of the PAS. The PAS term is applicable only when the targeted parent has not exhibited anything close to the degree of alienating behavior that might warrant the campaign of denigration exhibited by the child. Rather, in typical cases the parent would be considered by most examiners to have provided normal loving parenting or, at worst, exhibited minimal impairments in parenting capacity. It is the exaggeration of minor weaknesses and deficiencies that is the hallmark of the PAS". 
numa verdadeira folie a deux $x^{214}$ com o alienador, participando, junto dele, da campanha de difamação que terá por objetivo último obstaculizar, permanentemente, a relação entre o genitor alienado e o filho.

Portanto não é impossível, por exemplo, que se verifiquem, ainda que em grau leve e menos destrutivo, condutas de alienação parental durante a convivência familiar dos filhos e do casal parental enquanto este ainda é também um casal conjugal. Contudo, o palco principal para o desenvolvimento da alienação parental - e, portanto, eventualmente da sua síndrome - é formado por um conjunto de fatores que envolve, geralmente, os seguintes elementos mínimos: o desaparecimento da conjugalidade entre o casal parental de forma hostil, em que há atribuições de culpa; eclosão de sentimentos negativos entre um genitor e outro; e, finalmente, disputa entre os dois relativamente à guarda e ao direito de visitas dos filhos comuns - geralmente ainda menores de idade.

Quando concorrem, no processo de alienação parental de um genitor sobre o filho, não apenas a doutrinação do filho pelo genitor alienador, mas também contribuições da própria criança para a campanha de difamação do genitor alienado, se está diante daquilo que é chamado pela doutrina especializada de síndrome da alienação parental, que, ao contrário da alienação parental (que consiste de atos praticados pelo genitor alienador), tem como sujeito ativo e passivo, ao mesmo tempo, a criança. Ao sofrer a alienação parental, a criança coloca-se ao lado do genitor alienador, com quem mantém laços estreitos, que acabam se fortalecendo após a saída de cena da figura do genitor alienado em decorrência do fim da conjugalidade e, por vezes, do estabelecimento de novo relacionamento, inclusive com o nascimento de outros filhos.

\footnotetext{
${ }^{214}$ Gardner anota que "A SAP é um excelente exemplo de folie à deux (Francês: 'loucura a dois', ou 'dupla insanidade'). Folie à deux é uma forma de distúrbio psiquiátrico em que uma das partes (geralmente mais dominadora e autoritária) induz na outra parte (geralmente mais passiva e sugestionável) uma perturbação psiquiátrica. Por esse processo a primeira parte transmite sua patologia à segunda. Apesar de não ser uma forma de insanidade no sentido mais estrito, a SAP é uma perturbação psiquiátrica sob a forma de folie à deux. (...) Eu sempre mencionei como a sugestionabilidade das crianças e sua necessidade de se congraçar na autoridade adulta desempenha um importante papel no desenvolvimento da SAP. Este é um dos motivos pelos quais quanto mais velho o filho, menos chances haverá de uma doutrinação bem sucedida de SAP, embora essas crianças mais velhas sob hipótese alguma estejam imunes". In: GARDNER, Richard. The parental Alienation Syndrome. $2^{\text {nd }}$ ed. Cresskill, NJ : Creative Therapeutics Inc., 1998, p. 202. Tradução livre de: "The PAS is an excellent example of folie à deux (French: folly for two", or "double insanity"). Folieu à deux is a form of psychiatric disorder in which one party (usually the more domineering and authoritative) induces in another party (usually the more passive and suggestible) a psychiatric disturbance. By this process the first party transmits his (her) pathology to the second. Although not a form of insanity in the strictest sense, the PAS is very much a folie-à-deux form of psychiatric disturbance. (...) I have already mentioned how children's suggestibility and their need to ingratiate themselves to adult authority play an important role in the development of the PAS. This is one of the reasons why the older the child, the less the likelihood of successful PAS indoctrination, although older children are by no means immune".
} 
Salienta-se, portanto, que o tempo ${ }^{215}$ é a principal e mais poderosa arma do genitor alienador. É com o decorrer do tempo que o alienador terá mais sucesso em programar o filho contra o genitor alienado (alienação parental), até o ponto em que o próprio filho passe também a vilificar o genitor alienado, criando argumentos aparentemente próprios (mas que, em realidade, são emprestados das práticas e condutas do genitor alienador) para a cruzada de demonização que passa a sofrer o genitor-alvo, com a gradual destruição do vínculo afetivo entre este e os filhos alienados (síndrome da alienação parental).

Vislumbra-se, assim, a extrema importância de uma rápida verificação da ocorrência da alienação parental, ou mesmo da existência da síndrome da alienação parental, para que se possa agir de maneira igualmente rápida e eficaz, visando à minimização dos efeitos deletérios não apenas na criança, mas também na sua relação de afetividade com o genitor alienado.

\subsection{Alienação parental e abandono afetivo}

É importante, neste ponto, suscitar uma questão que, relativamente ao afeto, possui especial importância quando se trata especificamente do tema-objeto desta pesquisa, qual seja, a alienação parental. Nossos tribunais têm, nos últimos anos, julgado diversos casos envolvendo a afetividade entre os membros familiares - no caso, em espécie, a falta de afetividade. Trata-se do que se convencionou chamar abandono afetivo, que, linhas gerais, ocorre quando um genitor que não convive com o filho - seja porque se separou do outro

\footnotetext{
${ }^{215}$ Aponta Gardner que "A maioria dos pais no âmbito da disputa pela guarda sabe que o tempo está do lado do guardião. Eles avaliam que quanto mais tempo a criança permanece com um dos pais, maior a probabilidade dela temer e resistir à mudança para o domicílio do outro. Além disso, quanto mais tempo uma criança permanece com um dos genitores, maior a oportunidade que este terá de promover a lavagem cerebral do filho, para que este lhe destine apoio e lealdade na disputa pela guarda. Mesmo os adultos encontram na mudança de domicílio motivo para ansiedade. Uma maneira da criança lidar com esse medo é denegrir o pai não não-guardião com as críticas que justificam a sua permanência no domicílio do guardião. O tempo é considerado a arma mais poderosa para o genitor que promove a programação. Na verdade, não é tempo per se que dá poder a esta arma, mas a combinação do tempo $e$ da previsível lentidão do sistema legal. Se há uma coisa em que o genitor programador pode confiar com 99,9 por cento de certeza, é nos inevitáveis atrasos dos tribunais. (...) É quase como se o sistema tivesse sido projetado para auxiliar esses genitores". In: GARDNER, Richard. The parental Alienation Syndrome. $2^{\text {nd }}$ ed. Cresskill, NJ : Creative Therapeutics Inc., 1998, p. 200. Tradução livre de: "Most parents in the custody conflict know that time is on the side of the custodial parent. They appreciate that the longer the child remains with a particular parent, the greater the likelihood the child will fear and resist moving to the home of the other. Furthermore, the longer a child remains with a particular parent, the greater the opportunity that parent will have for brainwashing the child to provide professions of support and allegiance in the custody dispute. Even adults find change of domicile to be anxiety provoking. One way for a child to deal with this fear is to denigrate the non-custodial parent with criticisms that justify the child's remaining in the custodial home. Time is well considered the programming parent's most powerful weapon. Actually, it is not time per se that empowers this weapon, but the combination of time and the predictable slowness of the legal system. If there is one thing that the programming parent can rely upon with 99.9 percent of certainty, it is the inevitable delays of courts of law. (...) It is almost as if the system were designed to assist such parents".
} 
genitor, ou mesmo porque abandonou a genitora durante a gravidez, sequer vindo a conhecer o filho - se afasta completamente, ausentando-se da vida do filho de forma a não proporcionar-lhe carinho, amor, enfim, afeto, ao contrário de como se imagina que deva ocorrer no seio de uma família.

Muitas vezes o genitor que abandona afetivamente o filho não o deixa desamparado materialmente, cumprindo com suas obrigações alimentares, pagando a devida pensão e até mesmo provendo-lhe recursos para o custeio de outras despesas, como cursos extracurriculares, prática de esportes, e etc. Deixando o pai ou a mãe que não detém a guarda do filho de lhe prover as necessidades, não auxiliando o outro genitor no sustento e na educação da prole comum, indubitável que o Direito fornece os meios adequados para que tais deveres sejam cumpridos, através da ação de alimentos.

E diferentemente não poderia ocorrer: é responsabilidade de ambos os genitores contribuir para a manutenção dos filhos comuns, na proporção de seus rendimentos, e de acordo com as necessidades dos menores, conforme determinam os arts. 1.566, IV, 1.696, 1.694, § 1. o , e 1.703 do Código Civil. Portanto não há dúvidas quanto à obrigatoriedade da prestação de assistência material que os pais possuem para com os filhos, havendo inclusive a possibilidade de sanção penal ao descumpridor de tal obrigação.

Dúvida resta, contudo, no que concerne à questão da afetividade. Não se pode questionar o fato de que é vedado qualquer tipo de sanção sem que haja prévia existência de lei estabelecendo a punição para o cometimento de determinado ato, ou para a omissão a determinada ação obrigatória. Por isso é importante chegar a uma definição sobre qual a natureza jurídica do afeto.

Conforme se buscou demonstrar anteriormente, o afeto possui, sim, valor jurídico. Isso quer dizer que ele é, de fato, tutelado pelo Direito, e serve de parâmetro para a sua aplicação, por exemplo, para o reconhecimento de paternidade socioafetiva; para se garantir o direito de visita aos parentes com quem os menores possuem relação de afeto; para se ampliar o conceito de família e, assim, atribuir a guarda de menores que, de outro modo, seriam colocados em família substituta ${ }^{216}$; e mesmo para se determinar a guarda e o

\footnotetext{
${ }^{216}$ A Lei Nacional da Adoção (12.010/2009) alterou, no Estatuto da Criança e do Adolescente, o art. 25, nele incluindo um parágrafo único, que, nos seguintes moldes, define o conceito de "família extensa": "Entendese por família extensa ou ampliada aquela que se estende para além da unidade pais e filhos ou da unidade do casal, formada por parentes próximos com os quais a criança ou adolescente convive e mantém vínculos de afinidade e afetividade". Nota-se, mais uma vez, que o legislador, acertadamente, buscou preservar os vínculos de afetividade das crianças e dos adolescentes. Nesta hipótese, portanto, um menor abandonado pelos pais, ou cujos pais foram destituídos do poder familiar, não terá, necessariamente, de ser colocado em família substituta, podendo ter sua guarda atribuída a familiares próximos com quem possua vínculos de afeto.
} 
regime de $\operatorname{visitas}^{217}$. Nesses casos reconhece-se a existência de afeto como situação que enseja determinada consequência jurídica.

É como se se declarasse que existe relação de afetividade entre determinadas pessoas para que se lhes atribuam direitos e deveres que, normalmente, diante da inexistência do afeto, também não existiriam - daí o reconhecimento do afeto como valor jurídico, para se lhe atribuírem os decorrentes efeitos jurídicos.

No caso da alienação parental percebe-se outro tipo de situação: a existência da relação de afeto não é questionada, ela é inclusive presumida. O que ocorre é, por parte do genitor alienador, uma obstrução do exercício e do desenvolvimento dessa relação de afetividade entre seu filho e o outro genitor, relação essa que é protegida pela Constituição Federal. A obstaculização de tal relação afetiva paterno-filial, portanto, é contrária ao ordenamento, e deve ser rechaçada pelo Estado-juiz - daí, também, o reconhecimento do afeto como valor jurídico, para se lhe atribuírem os decorrentes direitos e deveres.

Resta identificar se o afeto possui o mesmo valor jurídico quando da ocorrência do abandono afetivo. Para tanto, forçoso trazer à discussão a emblemática decisão do Superior Tribunal de Justiça em ação movida pelo filho contra o pai, pleiteando indenização por abandono afetivo. Relatado pelo Ministro Fernando Gonçalves, o Recurso Especial 757.411/MG, julgado em 29 de novembro de 2005, está assim ementado:

Responsabilidade civil. Abandono moral. Reparação. Danos morais. Impossibilidade. 1. A indenização por dano moral pressupõe a prática de ato ilícito, não rendendo ensejo à aplicabilidade da norma do art. 159 do Código Civil de 1916 o abandono afetivo, incapaz de reparação pecuniária. 2. Recurso especial conhecido e provido ${ }^{218}$ (sem grifo no original).

GISELDA MARIA FERNANDES NOVAES HIRONAKA ${ }^{219}$, em profundo e completo artigo sobre o tema do abandono afetivo, inclusive analisando atentamente o julgado colacionado, sustenta a tese contrária, favorável à indenização por abandono afetivo, afirmando que:

Por direito ao pai, na sua valoração juridicamente relevante, devese entender o direito atribuível a alguém de conhecer, conviver, amar e ser amado, de ser cuidado, alimentado e instruído, de colocar-se em situação de aprendizado e de apreensão dos valores

${ }^{217}$ Conforme estipula o art. $1.583, \S 22^{\circ}$, I, a guarda unilateral será atribuída ao genitor que revele melhores condições para exercê-la e, objetivamente, mais aptidão para propiciar aos filhos afeto nas relações com o genitor e com o grupo familiar.

${ }^{218}$ STJ. REsp 757411/MG. 4. ${ }^{\text {a }}$ Turma, rel. Min. Fernando Gonçalves. J. 29.11.2005, DJe 27.03.2006. m.v.

${ }^{219}$ HIRONAKA, Giselda Maria Fernandes Novaes. Os contornos jurídicos da responsabilidade afetiva na relação entre pais e filhos: além da obrigação legal de caráter material. Disponível em: <http://www.ibdfam.org.br/?artigos\&artigo=289 > Acesso em: 19 de outubro de 2010. 
fundamentais da personalidade e da vida humanas, de ser posto a caminhar e a falar, de ser ensinado a viver, a conviver e a sobreviver, o que ocorre com a maioria dos animais que habita a face da Terra. Na via reversa, encontra-se o dever que tem o pai leia-se também, sempre, a mãe - de produzir tal convívio, de modo a buscar cumprir a tarefa relativa ao desenvolvimento de suas crias, que é, provavelmente, a mais valiosa de todas as tarefas incumbidas à raça humana.

É na afetividade que se desdobra o traço de identidade fundamental do direito gerado no seio da relação paterno-filial, que, sem deixar de ser jurídica, distingue-se de todas as demais relações justamente pelo fato de que ela, e apenas ela, pode, efetivamente, caracterizar-se e valorar-se, na esfera jurídica, pela presença do afeto.

(...)

A relação paterno-filial não é marcada pela transitoriedade como, de resto, é a característica intrínseca das relações de conjugalidade, entre as quais se incluem tanto as relações derivadas do casamento quanto as derivadas da união estável. $\mathrm{O}$ fato de ser a relação paterno-filial inamovível e perpétua lhe confere um traço ímpar, distinto de tudo o mais que se queira apreciar, em paralelo ou em comparação, na esfera do Direito de Família, ou no núcleo familiar. Esse traço diferencial, associado ao fato de não existir qualquer outra relação humana com maior potencialidade afetiva do que esta - natural e atávica -, é, provavelmente, o embrião do que se possa querer entender por direito ao pai.

Para a professora do Largo São Francisco "a ausência injustificada do pai origina evidente dor psíquica e consequente prejuízo à formação da criança, decorrente da falta não só do afeto, mas do cuidado e da proteção (função psicopedagógica) que a presença paterna representa na vida do filho". Assim, evidenciado o nexo de causalidade - o dano moral sofrido pelo filho abandonado afetivamente - haveria a eclosão do correspectivo dever de compensar o dano. Tal dever de compensar o dano moral derivado do abandono afetivo teria "os seus elementos constitutivos na funcionalização das entidades familiares, que devem tender à realização da personalidade de seus membros, com especial destaque para a pessoa do filho".

Hironaka conclui seu estudo ressalvando que, muito embora haja a possibilidade de que o reconhecimento do afeto como valor jurídico capaz de fazer incidir as regras gerais da responsabilidade civil para o caso da sua falta - ou seja, do abandono afetivo - possua o condão de incentivar lides temerárias e uma maior industrialização do dano moral,

a indenização por abandono afetivo, se for utilizada com parcimônia e bom senso, sem ser transformada em verdadeiro altar de vaidades e vinganças ou em fonte de lucro fácil, poderá converter-se em instrumento de extrema importância para a configuração de um Direito de Família mais consentâneo com a 
contemporaneidade, podendo desempenhar, inclusive, um importante papel pedagógico no seio das relações familiares.

É de se concordar com a professora quando expõe seus argumentos defendendo a penetração dos princípios constitucionais pelo Direito Civil, notadamente o Direito de Família, a reformular antigos posicionamentos que já não são mais admissíveis diante da evolução da sociedade.

Também não se nega, sob nenhuma hipótese, que aqueles filhos que se vêem abandonados por seus pais - que com eles não buscam manter um relacionamento afetivo que, espera-se, exista entre pais e filhos (buscando, opostamente, afastar-se da sua prole) estejam, na maioria das situações, fadados a sofrer, em algum nível, uma amarga experiência do descaso, do abandono, do desamor, perfeitamente capaz de gerar, portanto, um dano moral.

Não é de se crer, no entanto, que tal dano moral seja ensejador do dever de compensação por parte do genitor que pratica o abandono afetivo. Trata-se de conduta moralmente reprovável, isso é evidente. Não se espera outro sentimento de um pai que não o carinho, o amor e o afeto para com sua prole. O oposto é moralmente reprovável. Mas seria, também, juridicamente passível de sanção?

No que se refere à punição através da imposição do dever de compensar os eventuais danos morais, a resposta impõe-se negativa ${ }^{220}$. Não se discute o dever de ambos os genitores contribuírem, na proporção dos seus recursos, para a educação e o desenvolvimento dos filhos comuns - trata-se de imposição não apenas moral, mas também legal. Não é possível, contudo, defender uma compensação por abandono afetivo sem se reconhecer, primeiramente, que o sentir e demonstrar afeto é um dever que os pais possuem para com seus filhos. Não é.

Não se encontra, em meio aos defensores da compensação por abandono afetivo, quem defenda o posicionamento de que a indenização por abandono afetivo decorra, sim, da falta de afeto e de amor de um genitor para com seu filho. Fala-se em um caráter

\footnotetext{
${ }^{220}$ Forçoso relembrar, contudo, que o abandono afetivo é passível de sanção jurídica: através da perda do poder familiar, imposta ao genitor que pratica o abandono. Nesse sentido: "No caso de abandono ou do descumprimento injustificado do dever de sustento, guarda e educação dos filhos, porém, a legislação prevê como punição a perda do poder familiar, antigo pátrio-poder, tanto no Estatuto da Criança e do Adolescente, art. 24, quanto no Código Civil, art. 1638, inciso II. Assim, o ordenamento jurídico, com a determinação da perda do poder familiar, a mais grave pena civil a ser imputada a um pai, já se encarrega da função punitiva e, principalmente, dissuasória, mostrando eficientemente aos indivíduos que o Direito e a sociedade não se compadecem com a conduta do abandono, com o que cai por terra a justificativa mais pungente dos que defendem a indenização pelo abandono moral" (STJ. REsp 757411/MG. 4. ${ }^{a}$ Turma, rel. Min. Fernando Gonçalves. J. 29.11.2005, DJe 27.03.2006. m.v.).
} 
pedagógico da sanção, com o fito de desestímulo da conduta do genitor que se mostra irresponsável para com sua prole.

Com o devido respeito, tal posicionamento não se sustenta na lógica, pelos seguintes motivos:

- A condenação à reparação de danos é uma sanção, e, portanto, deve estar prevista em lei, dado o máximo princípio de que ninguém será obrigado a fazer ou deixar de fazer senão em virtude de lei: retire-se essa pedra fundamental para fazer desmoronar todo o sistema jurídico que há milênios nela se funda.

- A existência de afeto entre as pessoas - sejam marido e mulher, pais e filhos, irmãos e irmãs - não decorre, sob qualquer perspectiva, de imposição legal, se não suficientemente pela natureza do objeto e dos sujeitos, pela absoluta impossibilidade lógica: para que exista o afeto, é preciso simplesmente que as pessoas o sintam, sendo contrário à própria natureza que a existência de um sentimento, que nasce involuntariamente entre duas ou mais pessoas, seja imponível pelo Direito - e, portanto, com sua inexistência sendo passível de sanção.

- Parte do equívoco acerca da possibilidade de compensação pecuniária do abandono afetivo decorre da má interpretação dos dispositivos que garantem aos filhos o direito à convivência familiar, e que imputam como obrigação dos pais terem os filhos em sua companhia. Tal ilação é falaciosa, a uma, porque o direito à convivência familiar que aos filhos assiste não se contrapõe a um dever de convivência aos pais imposto, positivamente, mas sim à não obstrução indevida, por terceiros, do exercício dessa convivência; e, a duas, porque o próprio Código Civil, em seu art. 1.632, ressalva que, no caso de separação dos pais de filhos menores, com a atribuição unilateral da guarda, não se “alteram as relações entre pais e filhos senão quanto ao direito, que aos primeiros cabe, de terem em sua companhia os segundos" (sem grifo no original). Ou ainda conforme menciona o art. 1.634, II, que estabelece competir aos pais, quanto à pessoa dos filhos menores, tê-los em sua companhia e guarda. Está-se, obviamente, diante de uma das atribuições do poder-dever que é o poder familiar, que, sim, deve ser exercido em função do melhor interesse dos filhos, mas que, em momento algum, obriga aos pais que tenham os filhos em sua companhia e guarda. O poder familiar lhes garante o direito de convivência com os filhos, não cabendo a ninguém, salvo em casos justificados, nela interferir. Mas não obriga à convivência, porque não é possível obrigar qualquer pessoa que conviva com quem não deseja. Nem foi essa a intenção do legislador, ou mesmo do constituinte. A vontade da lei, no que toca ao direito à convivência familiar em sede de 
abandono afetivo, vem sendo reiteradamente desvirtuada pelos defensores da compensação por danos morais oriundos de tal abandono, para que não transpareça que o que se pretende punir é, sim, a não demonstração de um afeto que inexiste, e não uma pretensa violação, por parte do genitor que abandona afetivamente a prole, a deveres jurídicos supostamente impostos pelo ordenamento.

- Sem adentrar ainda mais profundamente no tema, por fugir ao escopo do presente estudo, traz-se ao debate, ainda, a contradição implicitamente contida nos argumentos dos que defendem a compensação pela ocorrência de abandono afetivo - mas não material por aquele que não se interessa em conviver com a própria prole, e que se silenciam quanto ao abandono afetivo e material praticado por aqueles que entregam os próprios filhos à adoção. É certo que se trata de questão a levantar polêmica, mormente pelas inúmeras vicissitudes a envolver a entrega de filhos à adoção, mas em momento algum se pode alegar que o dano sofrido pelos filhos quadruplamente abandonados - afetiva e materialmente, por ambos os genitores - não seja muito mais preocupante e devastador do que aquele sofrido pelo filho vítima de abandono afetivo, e não material, por apenas um dos genitores.

Vale informar, nesse tocante, que, de acordo com dados fornecidos pelo $\mathrm{CNJ}^{221}$ Conselho Nacional de Justiça -, até 31 de agosto de 2011, havia 27.477 pretendentes casais ou indivíduos - no cadastro de interessados em adotar crianças. Até a mesma data constavam do Cadastro Nacional da Adoção 4.860 crianças e adolescentes aguardando colocação em família substituta. À primeira vista poderia parecer, portanto, que dado o número de pretendentes ser quase seis vezes maior que o número de crianças aguardando serem adotadas, a adoção é questão que não suscita maiores preocupações no Brasil. Contudo, da análise mais detida dos dados, percebe-se uma triste realidade: quase $95 \%$ dos interessados na adoção não adotariam crianças maiores de 6 anos, que perfazem, contudo, cerca de $90 \%$ das crianças e adolescentes aguardando colocação em família substituta. Tais dados demonstram, dessa forma, a realidade cruel vivida pelos menores abandonados por aqueles que mais lhe deveriam fornecer carinho e amor, e que, no entanto, não costumam ser foco da atenção dos defensores da punição pecuniária pelo abandono afetivo.

É importante deixar claro que não se nega a possibilidade de o genitor que pratica o abandono afetivo seja compelido, por exemplo, a auxiliar no custeio de eventual tratamento psicoterápico necessário à tentativa de reajuste emocional do filho abandonado.

${ }^{221}$ SILVA FILHO, Artur Marques. Adoção: regime jurídico, requisitos, efeitos, inexistência e anulação. 3. ed. rev. atual. e ampl. São Paulo: Ed. RT, 2011, p. 170-172. 
Afinal o abalo moral, em casos de abandono afetivo, é mais do que possível, é de provável ocorrência, a produzir danos na esfera psíquica do filho abandonado. Tais danos não podem ser indenizados, nem reparados, mas podem ser trabalhados de forma a afetarem com menor intensidade os sentimentos da vítima. E, se tal trabalho psíquico puder ser efetivado por ajuda profissional, nada mais razoável que o genitor colabore para possibilitar tal tratamento, que não se diferencia de quaisquer outros tratamentos médicos que venham a ser necessitados pelo filho.

Carece de dúvidas, pois, que a indenização por abandono afetivo é indevida, por não existir norma legal que obrigue ao afeto - e inexiste norma nesse sentido porque a Lei não pode obrigar ao impossível. Casos em que, contudo, ocorre mais do que um simples abandono afetivo, havendo humilhação do filho, com cenas - públicas ou particulares - de desprezo e rejeição, ofensas, e mesmo a violação sistemática ao dever de sustento, a título exemplificativo, certamente ensejam a devida compensação pecuniária. Cumpre notar, contudo, que tal compensação pecuniária será devida pelo cometimento de ato ilícito, e não pela falta ou ausência de sentimento de uma parte para com a outra. A violência moral e afetiva é indenizável; a inexistência do afeto, não. 


\section{A INSTALAÇÃO DA ALIENAÇÃO PARENTAL}

\subsection{A disputa pela guarda como palco da alienação parental}

Conflito familiar. Poucos âmbitos são tão propícios à deterioração das relações humanas quanto o conflito familiar que escapa das muralhas da domus e alcança o Judiciário. E, muito embora obviamente não se atribua culpa às alterações normativas pelos resultados delas advindos, é de se reconhecer que a dessacralização do casamento, com as progressivas flexibilizações que culminaram na EC 66/2010 - que instituiu o divórcio direto, sem a exigência do cumprimento de qualquer prazo anterior -, foi um fator contributivo ao aumento dos conflitos envolvendo a disputa pela guarda dos filhos menores - que, por seu turno, abriu caminho para os conflitos envolvendo o direito de visitas. E o Judiciário, é claro, foi o destino lógico de toda essa beligerância entre ex-cônjuges ou excompanheiros. Afinal, é vedada a exclusão de apreciação pelo Judiciário de lesão ou ameaça a direito, com as inafastáveis garantias do devido processo legal e do contraditório.

Décadas depois da dessantificação do matrimônio, bem como da poderosa e incansável galgada feminina, dentro e fora da família, rumo à igualdade face aos homens, o que se presenciou foi uma virulenta profusão de demandas judiciais polarizando as partes e, o que é mais preocupante, cada vez mais afundando os filhos menores na incapacidade do casal parental de solucionar seus problemas de forma amigável. Homens e mulheres se tornaram iguais: ambos possuem as mesmas prerrogativas de arrastar toda a família para o abismo do litígio jurisdicionalizado.

Assim, pergunta-se: em termos práticos, e não teóricos, o processo judicial, como veículo, assim como o Poder Judiciário, como condutor, com sua atual estruturação, compreendem o âmbito adequado à solução dos conflitos da família pós-moderna? $\mathrm{Ou}$ serviriam eles também para acirrar tais desavenças? Sobre isso, RICHARD GARDNER opina que:

Em nenhum momento na história da civilização ocidental houve mais litígio sobre a guarda (...). Na maioria dos casos, as principais pessoas envolvidas na tomada das decisões - juízes e advogados têm pouca, ou nenhuma, formação no desenvolvimento infantil e psicologia. No entanto, é a eles que tradicionalmente tem sido atribuída a tomada de decisão sobre quem é o melhor genitor para fins de custódia, dentro do contexto de um sistema que pode ser um dos mais pobremente concebidos para ajudar a investigar e lidar com tais disputas. Muitas formas de psicopatologia resultam 
da utilização desse sistema como meio de resolver o divórcio e/ou os conflitos de custódia ${ }^{222}$.

O brasileiro está completamente adstrito à concepção de que quaisquer conflitos que demandem um pouco mais de reflexão para que se alcancem as soluções, deverão ser submetidos ao crivo do Poder Judiciário, lastreado num procedimento em que tudo deve ser provado pelas partes, e o que for provado por uma, desmentido pela outra.

Não se questiona que a resolução dos conflitos familiares através do processo, e, portanto, do Judiciário, seja, hoje, necessária. Mas a questão não é essa, e sim se tal forma de dirimir as contendas entre pessoas ligadas por vínculos tão estreitos é a adequada. A resposta não parece ser afirmativa. O procedimento judicial, tal como funciona atualmente, possui, sim, por conta de suas características de contraposição, e não composição de interesses, o condão de acirrar ainda mais as disputas que, mormente no espectro familiar, são naturalmente impregnadas de irracionalidade, irascibilidade, tensão e ressentimento. Todas essas variáveis, conjugadas, tendem a preparar o terreno para que, a depender apenas do grau de imaturidade e incapacidade parental dos genitores, a alienação parental seja semeada, cultivada e finalmente colhida.

\subsection{Alienação parental e alegação de abuso sexual}

Como deve proceder o julgador ao receber em suas mãos uma petição, de uma das partes que litigam pela custódia de um filho, em que se relata a ocorrência de abuso sexual, supostamente praticado pelo outro genitor, contra o menor cuja guarda se discute?

Se por um lado chega a ser abominável imaginar a hipótese de um genitor abusar sexualmente da própria prole - o que acontece, tristemente, com certa frequência -, não deixa de ser estarrecedor que um genitor, para afastar o outro do convívio com os filhos comuns, acuse-o falsamente, em juízo, de ter praticado tal abuso. E é com pesar que se admite que tal situação vem acontecendo com uma frequência cada vez maior.

A utilização da falsa denúncia de abuso sexual como ato de alienação parental poderia constar do item que tratará das manobras utilizadas pelo genitor alienador para promover a alienação parental. Contudo, dada a relevância deste ato - indiscutivelmente o

222 GARDNER, Richard. The parental Alienation Syndrome. $2^{\text {nd }}$ ed. Cresskill, NJ : Creative Therapeutics Inc., 1998, p. 41. Tradução livre de: "At no time in the history of Western civilization has there been more litigation over custody (...). In most cases, the people primarily involved in making such decisions - judges and attorneys - have little, if any, training in child development and psychology. Yet it is they who have traditionally been left with the decision as to who is the better parent for custodial purposes, working within the context of a system that may be one of the poorest yet devised to help investigate and deal with such disputes. Many forms of psychopathology result from the utilization of this system as a method for resolving divorce and/or custody conflicts". 
ato de alienação mais pernicioso e mais covarde que o alienador pode realizar -, preferiuse por tratar do tema em separado.

Segundo WILLIAM BERNET,

A maioria dos casos de SAP não envolvem alegações de abuso sexual. Em alguns casos de SAP, no entanto, a campanha de difamação inclui acusações falsas de abuso sexual. Esta é uma acusação forte, é claro, que recebe a atenção dos serviços de proteção à criança, dos responsáveis pela aplicação da lei, e do tribunal $^{223}$.

E não poderia ser diferente. A alegação de abuso sexual é grave demais para que seja desconsiderada, ainda que existam indícios da prática, por aquele que realizou a denúncia de abuso, de alienação parental.

Além disso, a questão da prova, em matéria de abuso sexual dos próprios filhos, é questão dificultosa, principalmente pelas características naturais do meio em que ocorre a alegação: a família. Nesse contexto, MARIA BERENICE DIAS aponta que:

O incesto é difícil de ser provado, independe da condição social da família, do nível econômico ou do desenvolvimento cultural do abusador. A primeira dificuldade decorre do fato de se tratar de prática que acontece no recinto do lar, entre quatro paredes. A prova, muitas vezes, limita-se ao confronto da palavra de um adulto com a de uma criança, que tem enorme dificuldade para relatar o ocorrido. Tudo isso dificulta a apuração de sua prática $(\ldots)^{224}$.

Dessa maneira, emergindo dos autos uma alegação de abuso sexual atribuído ao genitor descontínuo, ainda que seja, por óbvio, necessário averiguar de forma séria e implacável a veracidade da informação, que decisão deverá tomar o julgador? A questão probatória mostra-se complicada, podendo demandar a participação de diversos profissionais, como peritos médicos, psicólogos, assistentes sociais.

Trata-se de situação de difícil deslinde. Ao se sopesarem o direito à convivência familiar e a integridade física, psíquica e moral dos menores, não resta dúvida que qualquer direito que o genitor possua em manter a convivência familiar com seus filhos é irrelevante

\footnotetext{
${ }^{223}$ BERNET, William. Sexual abuse allegations in the context of child custody disputes. In: GARDNER, Richard A.; LORANDOS, Demosthenes; SAUBER, S. Richard (org.) The International Handbook of Parental Alienation Syndrome. 2nd ed. Springfield, IL : Charles C Thomas Publisher LTD, 2006, p. 247. Tradução livre de: "Most cases of PAS do not involve allegations of sexual abuse. In some cases of PAS, however, the campaign of denigration includes false allegations of sexual abuse. This is a powerful accusation, of course, that gets the attention of CPS [Child Protective Services], law enforcement personnel, and the court".

${ }^{224}$ DIAS, Maria Berenice. Incesto e o Mito da Família Feliz. In: DIAS, Maria Berenice (coord.). Incesto e Alienação Parental - realidades que a Justiça insiste em não ver. São Paulo: Ed. RT, 2007, p. 34.
} 
ante à proteção desses mesmos filhos, caso a alegação de abuso sexual seja, de fato, verdadeira.

Conforme expõe MARIA BERENICE DIAS,

Todas essas dificuldades probatórias acabam estimulando falsas denúncias de abuso sexual, com a só finalidade vingativa, principalmente em processos de separação. A tentativa do guardião é romper o vínculo de convívio paterno-filial com o outro genitor. É o que vem sendo chamado de implantação de falsas memórias. Desde que este tema passou a receber uma maior atenção, começou a haver um maior número de denúncias de ocorrência de incesto, principalmente em ações de disputa de guarda e regulamentação de visitas. (...)

A denúncia de práticas incestuosas tem crescido de forma assustadora. Essa realidade perversa pode levar a um injustificado rompimento do vínculo de convivência paterno-filial. Mas há outra conseqüência ainda pior: a possibilidade de se identificar como falsa denúncia o que pode ser uma verdade. Nos processos que envolvem abuso sexual, a alegação de que se trata de síndrome da alienação parental tornou-se argumento de defesa. Invocada como excludente de criminalidade, o abusador é absolvido e os episódios incestuosos persistem ${ }^{225}$.

É muito importante, dessa forma, a efetiva e diligente participação dos profissionais auxiliares da Justiça no sentido de averiguar a veracidade das acusações. Isso porque a demora em fazê-lo traz graves consequências, seja confirmada ou repelida a imputação. Se realmente ocorreu o abuso incestuoso, o dano decorrente de não terem sido tomadas providências no sentido de afastar o genitor abusador da criança molestada, e de não ter sido providenciado o tratamento psicológico adequado para o menor é, por óbvio, nefasto. Também se mostra perniciosa a situação quando, após o julgador ter suspendido cautelarmente o direito à convivência familiar, demora-se em demasia na revelação da verdade. Não sendo verídicas as acusações, o relacionamento afetivo entre o genitor acusado e o menor terá sofrido um forte abalo - que é precisamente o objetivo da conduta alienadora da qual partiu a acusação, se falsa. O julgador, diante de uma acusação de abuso sexual contra o genitor descontínuo, pode determinar a suspensão das visitas (se houver indícios reais de veracidade da acusação), ou determinar o acompanhamento profissional do período de convivência entre o genitor acusado e o filho ${ }^{226}$.

${ }^{225}$ DIAS, Maria Berenice. Incesto e o Mito da Família Feliz. In: DIAS, Maria Berenice (coord.). Incesto e Alienação Parental - realidades que a Justiça insiste em não ver. São Paulo: Ed. RT, 2007, p. 35.

${ }^{226}$ Nesse sentido, conferir o seguinte julgado: “Agravo de instrumento - Ação de modificação de guarda Suspensão do direito de visitas do pai - Alegação de abuso sexual - Matéria controvertida - Necessidade de dilação probatória - Deferimento do direito de visitas limitado ao período diurno e sob monitoramento do conselho tutelar. - Defere-se o direito de visitas se há controvérsia sobre os relatos de abuso sexual, mas 
Importante ressaltar a relevância de se averiguar com cautela toda acusação de abuso sexual contra o menor, para que não se corra o risco de permitir que acusações verdadeiras restem impunes e, ainda pior, se perpetuem. Não obstante, no caso da acusação ser comprovadamente falsa, com o mero intuito de interferir na relação entre o genitor acusado e o filho, restará configurado, além de ato de alienação parental - o mais grave deles -, o crime de calúnia, pela atribuição, a pessoa certa, de fato tipificado como crime.

\subsection{Manifestações da alienação parental na criança}

Conforme se advertiu anteriormente, reitera-se a imprescindibilidade de que esta pesquisa, ao trazer aspectos da alienação parental e da síndrome da alienação parental relativos à área da saúde mental, o faça de forma a reproduzir, o mais literalmente possível, a produção científica especializada no tema. Buscar complementar, por iniciativa própria, os dados coletados, seria atitude temerária, dada a ausência de especialização e, portanto, de qualificação técnico-científica para tanto. O objetivo, aqui, é trazer aos atores envolvidos na resolução de conflitos familiares - mormente aqueles relacionados à disputa pela guarda dos filhos menores quando da separação de seus pais - elucidações de cunho jurídico que, pela natureza do objeto de estudo, necessariamente passa pela área da saúde mental.

Marco teórico deste estudo, bem como, provavelmente, de todos aqueles que tratam da síndrome da alienação parental, a obra do Dr. Richard Gardner traz um detalhamento expressivo acerca de como a síndrome da alienação parental pode ser identificada nos principais sujeitos que a vivenciam: a criança, o genitor alienador e o genitor alienado. Gardner anota, assim, um rol de manifestações primárias observáveis nas crianças vitimizadas pela síndrome, ao qual ele dá o nome de oito sintomas cardinais da síndrome da alienação parental ${ }^{227}$ :

\section{a) A campanha de difamação;}

Conforme Gardner apontou, o diagnóstico da síndrome da alienação parental não se aplica quando, de fato, o genitor descontínuo praticou alguma forma de abuso contra o filho, o que poderia justificar o comportamento deste no sentido de maldizer o genitor e de evitar o contato com ele.

limitando-se ao período diurno e sob a supervisão de Conselheiro Tutelar" (TJMG. AgIn 019260587.2010.8.13.0000. 3. . Câm Cív., rel. Des. Silas Vieira. J. 12.08.2010. v.u.).

${ }^{227}$ GARDNER, Richard. The parental Alienation Syndrome. $2^{\text {nd }}$ ed. Cresskill, NJ : Creative Therapeutics Inc., 1998, p. 76. 
No entanto, num cenário em que inexiste a perpetração de qualquer prévia forma de abuso, o genitor que antes era amado pela criança, com quem ela vivenciava momentos de alegria e felicidade, transforma-se, inexplicavelmente, em alvo de toda sorte de reclamações e acusações por parte da própria criança. Garder informa que:

Geralmente, a criança está obcecada com o "ódio" ao genitor (a palavra ódio é colocada entre aspas porque (...) ainda existem muitos sentimentos de amor e carinho, cuja expressão não é permitida, em relação ao alegadamente desprezado genitor). Essas crianças se referem ao genitor alienado por meio de toda difamação e profanação existentes em seu vocabulário - sem embaraço ou culpa. (...) Depois de apenas um mínimo estímulo provocado pelo advogado, juiz, oficial de justiça, profissional de saúde mental, ou outra pessoa envolvida no litígio, a gravação no cérebro é ativada, e um comando é fornecido para que os defeitos do genitor alvo sejam listados à extensão. (...) A campanha de difamação possui dois componentes: a doutrinação pelo genitor alienador e contribuições da própria criança. Como mencionado, é esta combinação que garante o diagnóstico da SAP. Muitas vezes as contribuições da criança se sustentam na doutrinação do genitor e produzem elaborações nem sequer mencionadas pelo genitor programador. Em muitos casos, as elaborações são ridículas, e até mesmo absurdas, proporcionando assim a pista para que delas se desconfie. Foi a presença de contribuições incríveis que primeiro me levou à conclusão de que a campanha da criança não era simplesmente o resultado da programação parental; contribuições próprias da criança estavam exercendo um papel importante no fomento e enriquecimento dos cenários de depreciação ${ }^{228}$.

Um dos sintomas característicos da alienação parental, portanto, em relação à criança programada para rejeitar o genitor alienado, é essa participação quase irracional na campanha de difamação contra o genitor vilificado. Uma raiva completamente desproporcional aos eventuais - e comuns - defeitos do genitor, que leva a uma súbita

${ }^{228}$ GARDNER, Richard. The parental Alienation Syndrome. $2^{\text {nd }}$ ed. Cresskill, NJ : Creative Therapeutics Inc., 1998, p. 77. Tradução livre de: "Typically, the child is obsessed with 'hatred' of a parent. (The word hatred is placed in quotes because (...) there are still many tender and loving feelings felt toward the allegedly despised parent that are not permitted expression.) These children speak of the alienated parent with every vilification and profanity in their vocabulary - without embarrassment or guilt. (...) After only minimal prompting by a lawyer, judge, probation officer, mental health professional, or other person involved in the litigation, the brain recording will be turned on, and a command performance is provided in which the targeted parent's defects are listed at length. (...) the campaign of denigration has two components: the alienating parent's indoctrinations and the child's own contributions. As mentioned, it is this combination that warrants the PAS diagnosis. Often, the child's contributions will piggyback on the parent's indoctrinations and provide elaborations not even mentioned by the programming parent. In many cases the elaborations are ludicrous, and even preposterous, thereby providing the clue to the suspiciousness. It was the presence of incredible contributions that first led me to the conclusion that the child's campaign was not simply the result of parental programming; the child's own contributions were playing an important role in fueling and enriching the scenarios of deprecation". 
rejeição por parte do menor, portanto, devem indicar ao julgador que atente para a possibilidade da programação alienadora sobre a criança.

b) Racionalizações frágeis, frívolas e absurdas para a difamação;

Crianças que apresentam a SAP fornecem justificativas fúteis e inconsistentes para sustentar a campanha de vilificação contra o genitor alienado. Segundo Gardner,

A criança pode justificar a alienação com as memórias de leves desentendimentos ocorridos no relacionamento com o genitor-alvo, mesmo anos após terem ocorrido. São geralmente triviais, experiências que a maioria das crianças esquecem depressa, por exemplo: "ele sempre falava muito alto quando me dizia para escovar meus dentes", "sempre pedia para eu apanhar as coisas dele", "ela costumava me dizer "não interrompa"”. (...) Quando essas crianças são solicitadas a fornecer razões mais convincentes para a sua rejeição, eles não são capazes de fazê-lo. Tipicamente, o genitor alienador vai concordar com a criança que tais razões justificam a animosidade verificada ${ }^{229}$.

Além disso, "uma resposta comum que as crianças vítimas de SAP dão quando é perguntado por que eles não querem ver o genitor-alvo é: 'Eu não gosto dele (dela)', e eles encontram grande dificuldade em fornecer razões mais específicas ${ }^{230}$.

Dessa forma, tais justificativas baseadas em fatos que normalmente seriam relevados ou esquecidos rapidamente pela criança tendem a demonstrar que o menor, na ânsia de encontrar uma razão para a campanha de difamação, se apega a quaisquer fatos que supõe serem desabonadores da conduta do genitor vilificado.

\section{c) Ausência de ambivalência;}

Gardner informa que outro indício da instalação da alienação parental é a ausência de ambivalência. Segundo o especialista,

\footnotetext{
${ }^{229}$ GARDNER, Richard. The parental Alienation Syndrome. $2^{\text {nd }}$ ed. Cresskill, NJ : Creative Therapeutics Inc., 1998, p. 87. Tradução livre de: "The child may justify the alienation with memories of minor altercations experienced in the relationship with the targeted parent, even years after they have taken place. These are usually trivial and are experiences that most children quickly forget, e.g., 'he always used to speak very loud when he told me to brush my teeth', 'he used to tell me to get his things a lot', 'she used to say to me 'don't interrupt'. (...) When these children are asked to give more compelling reasons for their rejection, they are unable to provide them. Typically, the alienating parent will agree with the child that these professed reasons justify the ongoing animosity".

${ }^{230}$ GARDNER, Richard. The parental Alienation Syndrome. $2^{\text {nd }}$ ed. Cresskill, NJ : Creative Therapeutics Inc., 1998, p. 94. Tradução livre de: "A common response that PAS children provide when asked why they do not want to see the targeted parent is, 'I don't like him (her),' and they have great difficulty providing more specific reasons".
} 
Todas as relações humanas são ambivalentes e as relações paternofiliais não são exceção. Mas o conceito de sentimentos entrelaçados não tem lugar na forma como as crianças vítimas da SAP lidam com as coisas. O genitor-alvo é completamente ruim, e o genitor doutrinador é completamente bom. A maioria das crianças (normais, bem como aquelas com uma grande variedade de problemas psiquiátricos), quando solicitadas a listar coisas boas e ruins sobre cada um dos pais, geralmente serão capazes de fazêlo. Quando as crianças vítimas da SAP são convidadas a fazer o mesmo, elas normalmente vão recitar uma longa lista de críticas ao genitor-alvo, mas não serão capazes de pensar de um só traço de personalidade positivo ou benevolente. Em contraste, elas fornecerão apenas qualidades positivas e simpáticas em relação ao genitor alienador, e alegarão ser incapazes de lembrar nem mesmo de uma característica da qual não gostem. $O$ genitor vilifiado pode ter sido profundamente dedicado à educação da criança, e uma forte ligação pode ter sido mantida durante muitos anos. No entanto ela parece se evaporar, quase do dia para a noite, quando da instalação da SAP. Em contraste, o genitor alienador, em relação a quem a criança era anteriormente ambivalente (como ocorria com o genitor alienado) torna-se idealizada e "infalível"231.

Dessa forma, muito embora a criança certamente possua memória de aspectos positivos com relação ao genitor alienado, e, no mais das vezes, de alguns traços negativos acerca da personalidade do genitor alienador, não conseguirá admiti-lo.

\section{d) O fenômeno do "pensador independente";}

$\mathrm{Na}$ ânsia de proteger o genitor alienador e garantir a prevalência do seu posicionamento sobre o do genitor alienado, a criança tenderá a demonstrar o que Gardner chamou de "fenômeno do "pensador indepenente"”:

Muitas crianças vítimas da SAP orgulhosamente afirmam que a decisão de rejeitar o genitor-alvo é própria. Elas negam qualquer participação do genitor programador, que apoia veementemente essa "independência". $\mathrm{Na}$ verdade, alienadores normalmente afirmam que desejam que o filho visite [o genitor alienado], e alegam reconhecer a importância de tal relacionamento. No

\footnotetext{
${ }^{231}$ GARDNER, Richard. The parental Alienation Syndrome. $2^{\text {nd }}$ ed. Cresskill, NJ : Creative Therapeutics Inc., 1998, p. 94. Tradução livre de: "All human relationships are ambivalent, and parent-child relationships are no exception. But the concept of mixed feelings has no place in PAS children's scheme of things. The victimized parent is all bad, and the indoctrinating parent is all good. Most children (normal ones as well as those with a wide variety of psychiatric problems), when asked to list both good and bad things about each parent, will generally be able to do so. When PAS children are asked to provide the same lists, they will typically recite a long list of criticisms of the targeted parent, but will not be able to think of one positive or redeeming personality trait. In contrast, they will provide only positive and endearing qualities for the alienating parent and claim to be unable to think of even one trait they dislike. The vilified parent may have been deeply dedicated to the child's upbringing, and a strong bond may have been created over many years. Yet it seems to evaporate, almost overnight, at the time of the onset of the PAS. In contrast, the alienating parent toward whom the child was previous ambivalent (as was the case for the alienated parent) becomes idealizes an 'can do no wrong".
} 
entanto, todas as atitudes do doutrinador indicam o contrário. Crianças que sofrem de SAP percebem que, ao afirmar que a decisão é deles, aliviam a culpa do doutrinador (às vezes presente, e às vezes não) e protegem-no de críticas. Essas manifestações de pensamento independente são normalmente apoiadas pelo programador, que, muitas vezes, elogiarão os filhos por serem o tipo de pessoa que possui vontade própria e é honesta e corajosa o suficiente para expressar abertamente as suas opiniões. Além disso, a constante negativa do alienador quanto a quaisquer contribuições para a campanha de difamação acaba fortalecendo ainda mais a ilusão que a criança vítima da SAP possui de possuir pensamento independente. As negativas do programador geralmente ocorrem perante outros adultos - na presença dos filhos - e servem para confirmar a posição do doutrinador como sendo a parte inocente que está basicamente tentando apoiar a visitação ${ }^{232}$.

e) Apoio reflexivo ao genitor alienador no conflito parental;

A alienação se descortina, mais uma vez, na obsessiva necessidade que a criança alienada demonstra de defender o genitor alienador não apenas perante o juiz e os profissionais da equipe multidisciplinar, mas também perante a família.

Em conferências de família, em que os filhos estão na presença tanto do genitor alienante como do alienado, as crianças apoiam reflexamente genitor doutrinador - às vezes antes mesmo do genitor vitimizado ter tido a oportunidade de apresentar a sua versão da discussão. Até mesmo o genitor alienador pode não argumentar tão veemente quanto a criança que o apoia. Assim, as crianças vítimas da SAP podem até se recusar a aceitar evidências que provam cabalmente a versão do pai vilificado ${ }^{233}$.

${ }^{232}$ GARDNER, Richard. The parental Alienation Syndrome. $2^{\text {nd }}$ ed. Cresskill, NJ : Creative Therapeutics Inc., 1998, p. 96. Tradução livre de: "Many PAS children proudly profess that their decision to reject the targeted parent is their own. They deny any contribution from the programming parent, who supports this 'independence' vociferously. In fact, alienators will typically proclaim that they want the child to visit and profess recognition of the importance of such involvement. Yet, the indoctrinator's every act indicates otherwise. Children suffering from PAS appreciate that; by stating that the decision is their own, they assuage the indoctrinator's guilt (sometimes present, and sometimes not present) and protect the programmer from criticism. Such professions of independent thinking are typically supported by the programmer, who will often praise these children for being the kinds of people who have minds of their own and are forthright and brave enough to express overtly their opinions. Furthermore, the alienator's repeated denial of any contributions to the child's campaign of denigration further supports the PAS child's delusion of independent thinking. The programmer's denials are generally professed to other adults - in the presence of the children - and serve to support the indoctrinator's position that she (he) is the innocent one who is basically trying to support visitation".

233 GARDNER, Richard. The parental Alienation Syndrome. $2^{\text {nd }}$ ed. Cresskill, NJ : Creative Therapeutics Inc., 1998, p. 99. Tradução livre de: "In family conferences, in which the children are seen together with both alienating and the alienated parent, the children reflexly take the position of the indoctrinating parent sometimes even before the victimized parent has had the opportunity to present his (her) side of the argument. Even the alienating parent may not present the argument as forcefully as the supporting child. Thus PAS children may even refuse to accept evidence that is obvious proof of the vilified parent's position". 


\section{f) Ausência de culpa pela crueldade e pela exploração do genitor alienado;}

Este indício da prática de atos de alienação parental deve-se, no mais das vezes, também ao fato de o menor posicionar-se em constante apoio ao genitor alienador, como resultado de uma alienação bem sucedida. Segundo Gardner,

A criança pode apresentar um desrespeito desprovido de culpa aos sentimentos do genitor vitimizado. Haverá uma completa ausência de gratidão por presentes, pagamento de pensão, e outras manifestações de permanente envolvimento e afeto do genitor vilificado. Frequentemente as crianças vítimas da SAP buscarão se certificar de que o genitor alienado continue a pagar a pensão, mas ao mesmo tempo inflexivelmente recusam-se à visita. É comum que digam que nunca mais querem ver o genitor-alvo, ou ao menos não até o fim da adolescência (...) Muitos pais vítimas da SAP se encontram nesta situação. São demandados a fazer os sacrifícios necessários para financiar a educação, mas a mãe e os filhos não veem absolutamente nada de errado em fazer tais exigências, mesmo que as crianças não tenham contato algum com o pai. Crianças vítimas da SAP demonstram absolutamente nenhuma culpa por tal crueldade e exploração. Isso não é surpreendente quando se considera o fato de que o genitor alienador está apoiando totalmente tal comportamento ${ }^{234}$.

\section{g) Presença de cenários emprestados;}

A campanha de difamação da qual os menores participam junto do genitor alienador não se restringe às justificativas vazias e pouco críveis; a criança, não raro, passa também a repetir expressões e termos utilizados pelo programador, sendo perceptível que tal vocabulário não é próprio, dada a idade e o desenvolvimento da criança.

A presença de cenários emprestados pode servir aos examinadores de pista para a alta probabilidade de estarem lidando com um caso de síndrome de alienação parental. Não só a lista de reclamações das crianças vítimas de SAP possuem um tom ensaiado, como também muitas vezes verifica-se uma fraseologia que não é comumente utilizada por crianças dessa idade. Muitas expressões são idênticas às usadas pelo genitor doutrinador. Os termos e frases do genitor se tornam um script nas difamações da criança. Não raro

${ }^{234}$ GARDNER, Richard. The parental Alienation Syndrome. $2^{\text {nd }}$ ed. Cresskill, NJ : Creative Therapeutics Inc., 1998, p. 100. Tradução livre de: "The child may exhibit a guiltless disregard for the feelings of the victimized parent. There will be a complete absence of gratitude for gifts, support payments, and other manifestations of the vilified parent's continued involvement and affection. Often PAS children will want to be certain the alienated parent continues to provide support payments, but at the same time adamantly refuse to visit. Commonly they will say that they never want to see the targeted parent again (...). Many PAS fathers find themselves in this situation. They are asked to make the sacrifices necessary to finance the education, but the mother and children see absolutely nothing reprehensible in making these demands, even though the children will have no contact at all with their father. PAS children exhibit absolutely no guilt over such cruelty and exploitation. This is not surprising when one considers the fact that the alienating parent is supporting completely such (...) behavior". 
as crianças atribuirão uma declaração específica ao genitor programador, e assim "dar com a língua nos dentes", confirmando que a frase em particular foi programada ${ }^{235}$.

Tal programação não costuma ser preordenada pelo genitor alienador, mesmo porque ele tenderá a possuir o discernimento de que o menor não teria condições de conhecer determinadas palavras e expressões por si próprio, ficando claro que elas foram emprestadas do discurso do programador. Na maioria dos casos a criança utiliza, na campanha de difamação, termos cujo significado sequer conhece - e o faz reflexamente, repetindo o que ouviu o alienador dizer sobre o genitor alienado. Devido à estranheza que a utilização, por uma criança, de determinado vocabulário, identificar este elemento da alienação é relativamente simples, especialmente no caso de crianças de pouca idade.

\section{h) Extensão da animosidade à família do genitor alienado.}

As consequências da alienação parental inculcada nos filhos com frequência atingem não apenas o genitor alienado, mas também os seus familiares próximos. A esse respeito, Gardner aponta que:

No que respeita à difamação dos parentes, a criança é ainda menos capaz de fornecer justificativas para a animosidade. A raiva dessas crianças é muitas vezes tão grande que elas se tornam completamente alheias às privações que estão causando a si mesmas. Novamente, o genitor doutrinador mostra-se tipicamente despreocupado com os efeitos psicológicos indesejáveis, na criança, dessa rejeição ao círculo de parentes que, anteriormente, eram fonte de importantes benesses psicológicas ${ }^{236}$.

Isso porque uma das táticas do alienador é afastar a criança de todas as pessoas que possam, ainda que remotamente, servir de elo entre o menor e o genitor alienado. Os principais alvos costumam ser os avós - pais do genitor alienado -, especialmente se mantinham com a criança um relacionamento próximo e afetuoso. Sua influência sobre o

${ }^{235}$ GARDNER, Richard. The parental Alienation Syndrome. $2^{\text {nd }}$ ed. Cresskill, NJ : Creative Therapeutics Inc., 1998, p. 101. Tradução livre de: "The presence of borrowed scenarios should clue examiners in to the high probability that they are dealing with a parental alienation syndrome. Not only is there a rehearsed quality to PAS children's litanies, but one often hears phraseology that is not commonly used by children of that age. Many expressions are identical to those used by the indoctrinating parent. The parental terms and phrases become scripted into the children's litanies of denigration. Frequently, the children will attribute a particular statement to the programming parent, thereby 'letting the cat out of the bag' and confirming that the particular phrase has been programmed".

236 GARDNER, Richard. The parental Alienation Syndrome. $2^{\text {nd }}$ ed. Cresskill, NJ : Creative Therapeutics Inc., 1998, p. 107-108. Tradução livre de: "With regard to the denigration of the relatives, the child is even less capable of providing justifications for the animosity. The rage of these children is often so great that they become completely oblivious to the privations they are causing themselves. Again, the indoctrinating parent is typically unconcerned with the untoward psychological effects on the child of this rejection of the network of relatives who previously provided important psychological gratifications". 
menor, aos olhos do alienador, pode ser negativa, no sentido de, eventualmente, amenizar o ressentimento e a aversão desenvolvidos contra o genitor alienado.

Também a(o) nova(o) companheira(o) do genitor alienado tende a se tornar vítima da campanha de difamação e de vilificação perpetrada pelo alienador. E, com relação a esta figura em especial, os próprios menores - notadamente os mais jovens - tendem a desenvolver uma natural rejeição, que aumenta exponencialmente quando há a figura do alienador, ao incutir na concepção dos filhos que a nova companheira do genitor busca tomar o seu lugar como mãe e substituí-la na vida deles. Não é infrequente, nos casos mais severos de alienação parental, que a companheira acabe por não suportar a difícil situação, e afaste-se, ela também, do genitor alienado ${ }^{237}$. Justamente por isso, o genitor alienador poderá fazer de tudo para que os filhos rejeitem, ainda mais do que o outro genitor, a sua nova companheira. Especialmente se se tratar de uma relação séria, em que o genitor alienado se casou novamente, e talvez até tenha tido outros filhos, aumenta a possibilidade de desistir de lutar pelos filhos alienados e dedicar-se à nova família.

\subsection{Manifestações da alienação parental no genitor alienador}

Identificar, nos comportamentos do genitor alienador, os elementos caracterizadores da alienação parental é tarefa mais difícil que identificá-los nas atitudes da criança alienada. O genitor, naturalmente, possui mais condições de disfarçar suas atitudes e de ludibriar não apenas o juízo e o próprio advogado, mas até mesmo, eventualmente, os profissionais da equipe multidisciplinar - principalmente se não possuírem conhecimento específico acerca da alienação parental, hipótese em que aumenta exponencialmente a possibilidade de deixarem de identificar certos padrões de comportamento que, sendo típicos da alienação parental, forneceriam elementos importantes ao reconhecimento do processo de doutrinação e difamação.

E é de extrema importância que tal procedimento alienador seja identificado o quanto antes, especialmente para os casos em que não existe um deliberado e intencional propósito de destruir a relação entre a criança e o genitor alienado. Segundo anota Gardner,

Em pouco tempo, o processo de doutrinamento se torna tão automático e tão profundamente incorporado na estrutura psíquica do genitor programador que a programação é operada

${ }^{237}$ GARDNER, Richard. The parental Alienation Syndrome. $2^{\text {nd }}$ ed. Cresskill, NJ : Creative Therapeutics Inc., 1998, p. 219. 
reflexivamente, sem apreciação consciente de seus efeitos deletérios $^{238}$.

É necessário, assim, que se pergunte: qual a importância de se identificar se o comportamento alienador é consciente ou não?

A importância da identificação desse aspecto subjetivo da conduta alienadora terá especial lugar em duas situações: primeiramente, para eventual assistência psicológica ao genitor alienador. Se sua intenção não é interferir no relacionamento entre o filho e o outro genitor, um acompanhamento e aconselhamento terapêuticos podem, com sucesso, eliminar a conduta alienadora. Se, ao contrário, restar comprovado que a programação e o doutrinamento da criança, pelo genitor alienador, foi consciente, o reconhecimento de tal será importante, exemplificativamente, em eventual ação visando à compensação dos danos materiais e, principalmente, extrapatrimoniais sofridos tanto pela criança como pelo genitor alienado.

A conduta do genitor alienador para promover a alienação parental se dá através de uma gradual e constante programação da criança. Conforme é possível perceber no item anterior, a criança tende, naturalmente, a alinhar-se ao genitor que detém a sua guarda ${ }^{239}$, especialmente nos casos em que o outro genitor, mesmo antes da separação, deixou o lar. Assim, o genitor alienador passa a se referir ao outro, para a criança, como aquele que "abandonou" a família, que "os abandonou", assim, dessa forma, no plural. Na maioria dos casos o genitor que deixa o lar, qualquer seja o motivo, está, de fato, se afastando e rejeitando o outro genitor - o que não significa dizer que esteja abandonando o filho. Uma das principais táticas do genitor alienador é precisamente incutir nos filhos essa ideia e essa sensação de abandono, sempre incluindo-os, junto a si, dentre aqueles que foram abandonados pelo genitor alienado ${ }^{240}$.

Outra forma comumente utilizada pelo alienador é fazer a criança acreditar que sempre que o outro genitor não está presente em momentos importantes para o filho eventos da escola, prática de esportes, apresentações artísticas, etc. -, o faz porque não gosta de verdade do filho. Não é raro que o genitor alienador sequer tenha informado ao

${ }^{238}$ GARDNER, Richard. The parental Alienation Syndrome. $2^{\text {nd }}$ ed. Cresskill, NJ : Creative Therapeutics Inc., 1998, p. 130. Tradução livre de: "In short, the indoctrination process becomes so automatic and so deeply incorporated into the programming parent's psychic structure that the programming is performed reflexively, without conscious appreciation of their detrimental effects".

${ }^{239}$ A depender, importa relembrar, de diversos fatores, tais quais a idade e, assim, a capacidade da criança em identificar e compreender a situação de conflito que envolve seus pais. Quando mais nova a criança, maior a probabilidade de se alinhar fortemente com o genitor que detém a sua guarda e que, dessa forma, continua a ser presente e disponível no convívio do dia-a-dia do filho.

240 GARDNER, Richard. The parental Alienation Syndrome. $2^{\text {nd }}$ ed. Cresskill, NJ : Creative Therapeutics Inc., 1998, p. 134. 
alienado sobre a existência de tais eventos, e, através de tais comentários pejorativos, incutirá na criança, mais uma vez, o sentimento de abandono e de desimportância.

Especialmente quando já existe uma ação legal em curso, discutindo a guarda, o regime de convivência ou mesmo a própria alienação parental, o genitor alienador tenderá a, de todas as formas, fazer prova de que se comportam ao contrário do que na realidade acontece. Assim, escrevem e-mails, cartas, enviam mensagens por celular e deixam mensagens em secretárias eletrônicas em que demonstram total cooperação e apoio à manutenção da convivência entre o filho e o genitor alienado. Contudo suas ações tendem a indicar o oposto: suas atitudes não correspondem àquilo que professam, e a conduta de demonstrar cooperação, através de mensagens que, de alguma forma, são registradas, geralmente possui o intuito de fazer prova para o juízo, contra o genitor alienado ${ }^{241}$.

Outra forma muitas vezes utilizada pelo genitor alienador para obstaculizar a convivência entre o genitor alienado e o filho é agendar compromissos importantes no período de visita. Não apenas consultas médicas, odontológicas, aulas extracurriculares para que o tempo em que a criança passa com o genitor vitimizado seja ainda menor - mas também viagens, almoços familiares, passeios que seriam apreciados pelo filho. Assim, a criança terá de escolher o período com o genitor alienado ou a atividade proporcionada pelo genitor alienador. Se não puder escolher - por ter sido a visita determinada por decisão judicial, por exemplo -, e preferir participar da atividade programada pelo alienador, a criança tenderá a se irritar com a situação, e não raro culpará o genitor alienado por "fazê-la perder" aquela oportunidade ${ }^{242}$. Dada sua natural ausência de culpa e de consideração pela integridade psíquica do filho, poderá o genitor alienador, ainda, ao regresso da criança, contar em detalhes o quanto a atividade foi prazerosa e divertida, potencializando, assim, de forma ainda mais acentuada, a animosidade do filho contra o genitor alienado, que passará a ser visto como vilão, como “estraga-prazeres".

Além disso, o alienador costuma ser bastante inflexíveis quanto aos horários de visitas, não tolerando mínimas variações nos horários estabelecidos para o genitor ir buscar e ir entregar o filho de volta. Não admitem qualquer tipo de atraso, e não raro telefonam para o advogado para reportar o que consideram "descaso" por parte do genitor alienado, o que demonstra sua "incapacidade de comprometer-se" com o filho, e, portanto, de exercer a paternidade (maternidade). Em grandes cidades, em que o estabelecimento de horários se

${ }^{241}$ GARDNER, Richard. The parental Alienation Syndrome. $2^{\text {nd }}$ ed. Cresskill, NJ : Creative Therapeutics Inc., 1998, p. 136.

${ }^{242}$ GARDNER, Richard. The parental Alienation Syndrome. $2^{\text {nd }}$ ed. Cresskill, NJ : Creative Therapeutics Inc., 1998, p. 143. 
mostra particularmente prejudicado pelo trânsito caótico, a intolerância quanto a atrasos ocasionais e justificados demonstra claramente que a preocupação do genitor detentor da guarda não se centra no bem estar do filho, através da convivência com o outro genitor.

O telefone também é uma importante ferramenta do genitor alienador para comprometer os períodos de convivência entre o filho e o genitor alienado.

Uma criança, por exemplo, quando conversando com o alienador da residência do genitor alienado, tende a hesitar em falar com franqueza. A criança pode entender que admitir passar bons momentos ali será algo desaprovado pelo alienador. Dessa forma, a criança poderá alegar que está entediada, ou afirmar que não tem absolutamente nada a dizer sobre o que aconteceu láa ${ }^{243}$.

Além disso, com frequência o genitor alienador contata o filho pelo celular, durante o período de convivência, a pretexto de querer saber o que está acontecendo, onde o filho está, se está bem, se precisa de algo. Essa conduta possui um objetivo claro: o de despertar na criança a sensação de que não está segura longe do alienador, e especialmente em perigo quando junto do genitor alienado.

Reiteradas alegações de que o genitor alienado não possui capacidade, tempo ou disposição para cuidar dos filhos também podem constituir argumentos do genitor alienador que, direcionados não ao juiz, mas aos próprios filhos, tendem a se incorporar nas manifestações dos menores quando forem se referir ao genitor vitimizado especialmente quando concorrem pequenas e irrelevantes faltas no exercício da paternidade, que acabam por, na mente da criança, corroborar com os argumentos alienadores.

Expressamente vedado pela Lei da Alienação Parental, a obstrução do acesso do genitor alienado aos aspectos escolares e médicos dos filhos é outra forma de promover a alienação. Se a animosidade entre os genitores chegar a ponto de não suportarem estar no mesmo lugar ao mesmo tempo, as escolas devem providenciar, se não reuniões de pais e mestres separadas, ao menos a oportunidade do genitor não-guardião de obter acesso não só aos registros de desempenho escolar dos filhos, mas também aos professores destes, de forma a se inteirar inclusive do comportamento da criança na sala de aula.

\footnotetext{
${ }^{243}$ GARDNER, Richard. The parental Alienation Syndrome. $2^{\text {nd }}$ ed. Cresskill, NJ : Creative Therapeutics Inc., 1998, p. 140. Tradução livre de: "A child, for example, when speaking to the alienator from the alienated parent's home, is likely to be hesitant to speak freely. The child may recognize that any admission of good times there is going to be met disapprovingly by the alienator. Accordingly, the child may claim boredom or state that he (she) has absolutely nothing to tell the alienating parent about what has gone on there".
} 
O genitor alienador pode, ainda, buscar fazer com que a criança se sinta mal por "deixá-lo sozinho para ir visitar o outro genitor". Gardner lembra que o fato que mais contribui para a instalação da síndrome da alienação parental é que o laço psicológico primário da criança é muito mais forte com o genitor alienador ${ }^{244}$, que geralmente prevaleceu como principal referência de cuidado e proteção nos primeiros anos de vida da criança. Por isso, via de regra, a criança tende a buscar, a todo custo, preservar esse laço, o que redunda no seu consequente alinhamento junto ao genitor alienador.

Dessa maneira, esse medo de rompimento do laço psicológico primário acaba, muitas vezes, fazendo com que a criança mais tema que ame o genitor alienador ${ }^{245}$. Não é raro encontrar situações em que a criança se sente culpada se passar por momentos alegres e felizes com o genitor alienado, motivo pelo qual pode passar a afirmar que a convivência com o genitor vitimizado não é prazerosa, apenas com o intuito de agradar o alienador.

Outra conduta clássica do genitor alienador é a de mudar de domicílio com frequência, por motivos às vezes aparentemente justificados, como transferência no emprego, cuidados a parentes doentes que vivem em outra cidade, necessidade de criar os filhos em um ambiente mais seguro, ou que ofereça mais oportunidades de educação de qualidade. Prevista na Lei de Alienação Parental como exemplo de atitude alienadora, a constante mudança de domicílio - ou, ainda que não constante, a mudança para um local distante e de difícil acesso ao outro genitor - deve ser evitada, a não ser em casos de comprovada indispensabilidade. Afinal, muito embora, conforme se concluiu no capítulo referente à guarda, a atribuição desta acabe por conferir ao guardião alguma margem de discricionariedade em relação às decisões a serem tomadas referentemente à criança, questões de maior relevância - como o é a decisão de, por exemplo, mudar-se para outro estado - deve, necessariamente, ser discutida com o outro genitor, sob pena de se lhe retirar, indevidamente, o poder decisório que a autoridade parental - que não desaparece pelo simples fato de não estar incumbido da guarda - lhe confere.

Vê-se, portanto, que a conduta do genitor alienador só encontra limites na sua própria criatividade. Conforme se mencionou anteriormente, o tempo é o maior aliado do genitor alienador, pois ele permite a gradual programação dos filhos que, ainda que o genitor arrefeça em sua campanha de difamação do genitor alienado, as crianças lhe darão continuidade, uma vez que a ideia de que o genitor vilificado é ruim, desprezível, já se

${ }^{244}$ GARDNER, Richard. The parental Alienation Syndrome. $2^{\text {nd }}$ ed. Cresskill, NJ : Creative Therapeutics Inc., 1998, p. 110.

${ }^{245}$ GARDNER, Richard. The parental Alienation Syndrome. $2^{\text {nd }}$ ed. Cresskill, NJ : Creative Therapeutics Inc., 1998, p. 110. 
incorporou à própria percepção dos filhos, que passam a denegrir o genitor alienado por si $\operatorname{mesmos}^{246}$. A depender do grau de animosidade com que o alienador promoveu a campanha de difamação, e da sugestionabilidade das crianças, bem como do histórico familiar como um todo, a demora na intervenção profissional pode permitir a ocorrência de danos irreversíveis ao relacionamento entre o genitor alienado e os filhos.

\subsection{Reflexos da alienação parental no genitor alienado}

Diante do exposto nos dois itens anteriores, em que se buscou apontar as principais manifestações, na criança, da alienação parental perpetrada pelo genitor alienador, por meio das mais diversas táticas, cumpre agora identificar o comportamento do genitor alienado diante da situação de alienação parental na qual ele se encontra imerso.

Excetuando-se a minoria de casos em que, após a separação, o genitor não-guardião de fato não se interessa em manter contato com os filhos, partindo para uma nova vida e “deixando para trás" a família anterior (hipótese em que se configura, de fato, o abandono afetivo), a situação do genitor alienado se torna, para dizer o mínimo, tormentosa. Aquele que sempre atuou de maneira carinhosa, diligente e preocupada na criação dos filhos vê-se, de uma hora para outra, privado da convivência com eles, e, desesperadoramente, vítima de uma intensa e cruel campanha de difamação. Deflagrada pelo alienador, essa campanha faz com que seus filhos - outrora igualmente carinhosos e amorosos - passem a rejeitar a sua figura como pai, às vezes em intensidade tal que acompanham a cruzada de vilificação iniciada pelo alienador, dando suas próprias contribuições, sem qualquer sentimento de piedade ou de culpa pelo sofrimento que infligem ao genitor, antes amado, agora alienado.

RICHARD A. GARDNER ${ }^{247}$ aponta que inicialmente o sentimento prevalente no genitor alienado é de confusão. Seus filhos, que anteriormente eram carinhosos e afetuosos, passam a exibir comportamento hostil, virulento, por vezes até mesmo profundamente desrespeitoso.

Além disso, os genitores alienados passam a sofrer com um profundo sentimento de impotência, principalmente porque suas tentativas iniciais - mormente quando em momento ainda extrajudicial, anterior às acusações de obstrução do direito à convivência familiar - se mostram inócuas, incapazes de produzir qualquer resultado junto aos seus filhos. Não é raro, ainda, que parentes - do genitor alienado ou do alienador -, muito

${ }^{246}$ GARDNER, Richard. The parental Alienation Syndrome. $2^{\text {nd }}$ ed. Cresskill, NJ : Creative Therapeutics Inc., 1998, p. 187.

${ }^{247}$ GARDNER, Richard. The parental Alienation Syndrome. $2^{\text {nd }}$ ed. Cresskill, NJ : Creative Therapeutics Inc., 1998, p. 209-211. 
embora percebam a situação, prefiram não intervir diretamente, sob pena de, eles também, serem vítimas da programação e da segregação promovida pelo alienador.

Tal sentimento de impotência demonstra-se especialmente tormentoso quando o genitor alienado finalmente percebe que, em algumas situações, o agir contra o processo alienador tem potencial para se demonstrar atitude ainda mais desastrosa que o não agir. Em algumas ocasiões, a repulsa dos filhos pelo alienado é tão intensa, tão cruel que o genitor vilificado chega à conclusão de que se impor na vida dos filhos, obrigá-los à sua convivência é medida que apenas gera ainda mais conflito - e que melhor seria, portanto, esperar que cresçam e passem a compreender mais claramente a situação.

Pode ocorrer, ainda, que o genitor seja tão atacado, tão fortemente humilhado e mal-quisto pelos filhos que passa a acreditar que talvez, no fim das contas, afastar-se seja, de fato, a melhor solução.

Esses são equívocos comuns, e que geralmente possuem o condão de aniquilar, de uma vez, a possibilidade de retomada da relação de afeto entre o genitor alienado e os filhos. É preciso lembrar que a alienação perpetrada pelo genitor alienador retira das crianças a sua posição ambivalente face às figuras parentais. Conforme se mencionou, o alienador passa a ser expressão suprema e intangível daquilo que é bom, e o genitor alienado passa a personificar tudo que há de ruim. Os filhos são programados, no âmbito psíquico, de maneira direta ou indireta, a repudiar a figura do genitor alienado. Não apenas não se trata, por parte das crianças, de uma atitude culposa: ela é também inelutável. As atitudes dos filhos, muito embora às vezes pareçam emanar deles próprios, de suas próprias convicções e opiniões, são, ainda que indiretamente, meros reflexos do que o alienador pensa e sente em relação ao genitor alienado.

A proposição de ação judicial contra o alienador, também, possui efeitos contrastantes e ambíguos. Apesar de ser, efetivamente, a única forma pela qual o genitor alienado pode tentar reverter o processo de alienação, impedindo o alienador de obstruir a sua convivência com os filhos, não é raro que o genitor programador se utilize desse fato para induzir ainda mais os filhos a apoiá-lo e, consequentemente, rechaçar a figura do outro genitor, sob o argumento de ser apenas uma vítima da ação judicial movida.

Não é incomum, também, que o genitor alienado não disponha de recursos suficientes para enfrentar judicialmente, ombro a ombro, a alienação de que é vítima. Principalmente porque a contratação de assistentes técnicos que elaborarão pareceres direcionados ao julgador, bem como quesitos direcionados aos peritos judiciais, costuma ultrapassar a capacidade financeira da parte, que além de possuir os gastos ordinários para 
seu próprio sustento, bem como o sustento dos filhos por quem luta, por vezes terá constituído nova família - que não apenas também necessita do seu amparo, mas também que pode se ressentir dos gastos referentes a uma disputa judicial que diretamente não lhe diz respeito. 


\section{O COMBATE À ALIENAÇÃO PARENTAL}

O esforço para se combater a prática e os resultados deletérios advindos da alienação parental devem ser conjuntos, não há dúvidas. Todos os atores envolvidos na trágica peça da obstrução ao direito de convivência familiar que assiste aos genitores e, principalmente, às crianças e adolescentes, devem agir de maneira adequada, rápida e eficaz, sob pena de se permitir a violação aos mais fundamentais direitos assegurados aos menores. Conforme leciona ROBERTO JOÃO ELIAS, não se pode negar a existência de valores supremos, que são imprescindíveis ao relacionamento humano, sendo a família uma instituição necessária ao pleno desenvolvimento da personalidade do homem, "pelo que o direito que o menor tem de crescer e desenvolver plenamente sua personalidade, dentro do grupo familiar, não pode ser, de forma alguma, relegado a um plano secundário"248. Insta, portanto, reconhecer que a prática de condutas que agridam a efetivação de tais direitos deve ser prontamente combatida.

\subsection{Alienação parental como forma de abuso à criança e ao adolescente}

Poder-se-ia questionar, antigamente, se a obstaculização ao direito de convivência dos filhos e do genitor descontínuo configuraria ilícito passível, portanto, de sanção. Conforme exposto anteriormente, crê-se que a obstrução ao direito de visitas, por si só, já configura ato ilícito, gerador, ao menos, de dano moral indenizável - tanto em favor do menor como do genitor não-guardião cujo direito à convivência com o filho é obstruído. TÂNIA DA SILVA PEREIRA, evocando a possibilidade de configuração de abuso de direito a obstrução da convivência do menor com seus familiares, ressalta:

O genitor e o filho impedidos de se comunicar poderão ser vítimas e postulantes ativos de uma ação de indenização. A reiterada obstrução da comunicação do visitante com o filho, cujo relacionamento é fundamental para o desenvolvimento de sua personalidade, assim como deixar o menor em mãos de terceiros durante o tempo das visitas ao invés de tê-lo em sua companhia; mudar para outro estado ou município geograficamente distante, para rarear ou onerar o exercício da visitação; o habitual e reiterado atraso na devolução do menor; o injustificado e reiterado atraso em buscar o menor para o ato de visitação; a não-devolução do filho ao seu guardião $(. . .)^{249}$.

\footnotetext{
248 ELIAS, Roberto João. Comentários ao Estatuto da Criança e do Adolescente: (Lei n. 8.069, de 13 de julho de 1990). 3. ed. São Paulo: Saraiva, 2008, p. 21.

${ }_{249}$ PEREIRA, Tânia da Silva. Direito da criança e do adolescente - uma proposta interdisciplinar. 2. ed. rev. e atual. Rio de Janeiro: Renovar, 2008, p. 208-209.
} 
Além disso, o impedimento ao exercício de tal fundamental direito, quando não ocorre de maneira direta, ou seja, através da obstrução física, configura conduta de alienação parental, tema sobre o qual JANELLE BURRILL enfatiza que:

Especificamente, trata-se de uma forma de abuso emocional que pode causar a perpétua alienação da criança de um genitor carinhoso, e gerar permanente distúrbio psiquiátrico no menor. $\mathrm{O}$ genitor alienador demonstra completo desprezo pelo papel do genitor alienado na criação da criança. Causa uma atenuação e até mesmo a total destruição de um laço psicológico que poderia, na maioria dos casos, ser de grande valor para o menor, especialmente quando os pais são separados ou divorciados. Genitores alienadores demonstram um sério déficit parental que deve ser levado em consideração pelos tribunais ao decidirem acerca da atribuição primária da guarda ${ }^{250}$.

Também RICHARD GARDNER aponta a necessidade de se considerar a síndrome da alienação parental uma forma de abuso contra a criança:

O abuso emocional é muito mais difícil de se verificar objetivamente, especialmente porque muitas formas de abuso emocional são sutis e de difícil constatação num tribunal. A SAP, entretanto, é, na maioria das vezes, facilmente identificável, e os tribunais fariam bem em considerar a sua presença uma manifestação de abuso emocional por parte do genitor programador $^{251}$.

JORGE TRINDADE também vê na síndrome da alienação parental uma "forma grave de maltrato e abuso contra a criança, que se encontra especialmente fragilizada por estar vivendo um conflito que envolve a figura de seus próprios pais" ${ }^{252}$.

É de se perquirir, dessa forma, acerca de quais as possíveis sanções aplicáveis ao alienador, após constatada a alienação. Consoante determina o art. 3. ${ }^{\circ}$ da Lei da Alienação Parental,

${ }^{250}$ BURRILL, Janelle. Reluctance to verify PAS as a legitimate syndrome. In: GARDNER, Richard A.; LORANDOS, Demosthenes; SAUBER, S. Richard (org.) The International Handbook of Parental Alienation Syndrome. 2nd ed. Springfield, IL : Charles C Thomas Publisher LTD, 2006, p. 325. Tradução livre de: "Specifically, it is a form of emotional abuse that can produce a child's lifelong alienation from a loving parent and lifelong psychiatric disturbance in the child. The alienating parent exhibits complete disregard for the alienated parent's role in the child's upbringing. The alienating parent causes an attenuation and even total destruction of a psychological bond that could, in most cases, prove of great value to the child, particularly since the parents are separated or divorced. Alienating parents exhibit a serious parental deficit that should be given serious consideration by courts when deciding primary custodial status".

${ }^{251}$ GARDNER, Richard. The parental Alienation Syndrome. $2^{\text {nd }}$ ed. Cresskill, NJ : Creative Therapeutics Inc., 1998, p. xxii. Tradução livre de: "Emotional abuse is much more difficult to assess objectively, especially because many forms of emotional abuse are subtle and difficult to verify in a court of law. The $P A S$, however, is most often readily identified, and courts would do well to consider its presence a manifestation of emotional abuse by the programming parent".

${ }^{252}$ TRINDADE, Jorge. Síndrome da Alienação Parental. In: DIAS, Maria Berenice (coord.). Incesto e Alienação Parental - realidades que a Justiça insiste em não ver. São Paulo: RT, 2007, p. 109. 
Art. 3. ${ }^{\circ}$ A prática de ato de alienação parental fere direito fundamental da criança ou do adolescente de convivência familiar saudável, prejudica a realização de afeto nas relações com genitor e com o grupo familiar, constitui abuso moral contra a criança ou o adolescente e descumprimento dos deveres inerentes à autoridade parental ou decorrentes de tutela ou guarda (sem grifo no original).

O dispositivo em comento, muito bem redigido, não deixa qualquer dúvida acerca do caráter de ato ilícito da conduta alienadora, muito embora não elenque as consequências advindas de tais violações a direitos. Em verdade, nem seria necessário que o fizesse, pois o próprio ordenamento jurídico é capaz de fornecer as consequências derivadas dos atos expressamente mencionados.

Se a prática de ato de alienação parental "fere direito" da criança, "prejudica a realização de afeto" da criança com o genitor e o grupo familiar, bem como "constitui abuso moral contra a criança e o adolescente", não resta a menor dúvida de que estamos diante de um ato ilícito, na forma do art. 186 do Código Civil, por consistir, a conduta alienadora, clara violação a direito e provocação de dano, ainda que exclusivamente moral, por expressa determinação legal. Assim, em consonância com o art. 927 do CC/2002, surgirá o dever de indenizar.

E quem possuirá legitimidade para pleitear indenização decorrente da obstrução ao direito à convivência familiar? Quanto ao menor alienado, não há o que se discutir. Sendo privado do saudável convívio com seus familiares, em decorrência da conduta do guardião, assistirá ao menor o direito à devida compensação por danos morais. No entanto, baseado nos mesmos princípios e justificativas, é de se estender também ao genitor alienado a legitimidade para, em nome próprio, perseguir compensação pelos danos morais sofridos. Afinal, não é possível afirmar que a situação advinda da alienação parental perpetrada pelo alienador não teria o condão de infligir ao alienado profundo abalo psíquico e dor moral.

Também os demais familiares com quem a criança possua relacionamento afetivo parecem figurar no rol de legitimados a pleitear a compensação dos danos morais, caso reste comprovada a anterior proximidade entre eles e o menor alienado.

No que se refere ao descumprimento dos deveres inerentes à autoridade parental, tutela ou guarda, mais uma vez, enfatiza-se que a solução não é a compensação de danos, e sim a adoção das medidas previstas no próprio ECA, que prescrevem penas de alteração da guarda, suspensão e até mesmo a perda do poder familiar. Portanto, configurada a alienação parental, não resta dúvida de que, além das medidas específicas a serem tomadas pelo julgador para evitar a sua persistência (art. $6^{\circ}$ da Lei da Alienação Parental), serão 
cabíveis, ainda, a perda do poder familiar por descumprimento dos deveres inerentes à autoridade parental, bem como a compensação decorrente do ato ilícito gerador de dano moral, tanto à criança como ao genitor alienado, e, a depender do caso, também aos familiares privados do convívio com o menor.

Importante observar que, conforme já tratado anteriormente, o exercício da guarda é parte da autoridade parental - que, por sua vez, não é um direito, uma prerrogativa do guardião: é muito mais um rol de deveres. Dentre esses deveres inclui-se o de exercer tal autoridade parental com o cuidado que tal múnus exige, para que sempre seja preservado o melhor interesse do menor. Nesse sentido, TÂNIA DA SILVA PEREIRA enfatiza que:

Ao assumirmos o "cuidado" como valor jurídico e como denominador comum do sistema especial de proteção para a infância e juventude, devemos configurá-lo na dimensão da responsabilidade, pressupondo a clarificação de valores essenciais à convivência humana ${ }^{253}$.

Assiste razão à jurista. Atribuindo-se ao cuidado um valor jurídico, é ele alçado à categoria de dever jurídico, a cuja inobservância deve corresponder, necessariamente, uma sanção, uma vez que um dever jurídico ao qual não corresponda uma sanção acaba se tornando mero conselho, simples recomendação, sem força impositiva. E, tratando-se a proteção da criança e do adolescente questão primordial e fundamental, conforme determinação da própria Carta Magna, impossível cogitar que do descumprimento de um dever para com a proteção da criança e do adolescente não advenha uma sanção.

\subsection{O papel do advogado}

O advogado é indispensável à administração da justiça, diz o art. 133 da CF/1988. E, de acordo com o art. 2..$^{\circ}$ da Lei 8.906/1994, o Estatuto da Advocacia, o advogado presta serviço público e exerce função social ( $\left.\$ 1 .^{\circ}\right)$, tendo como função postular decisão favorável ao seu constituinte, por meio do convencimento do julgador, e constituindo, seus atos, múnus público $\left(\S 2 .^{\circ}\right)$.

Ora, todas as pessoas têm o direito de buscar ver seus interesses resguardados, e quando se trata de disputas judiciais, salvo raras exceções, deverão se fazer representar por um advogado. E é essencial que assim o seja: como profissional especializado, conhecedor do Direito e do funcionamento do processo, sua ausência colocaria em risco a efetivação dos direitos da parte.

${ }^{253}$ PEREIRA, Tânia da Silva. Direito da criança e do adolescente - uma proposta interdisciplinar. 2. ed. rev. e atual. Rio de Janeiro: Renovar, 2008, p. 168. 
Contudo, despindo a situação de qualquer visão idealizada da profissão, é preciso atentar para o fato de que o advogado, muito embora exerça função pública, é um profissional, contratado pela parte para defender seus interesses - legítimos ou não. Aliás, não cabe ao advogado tecer considerações profundas acerca da legitimidade dos pleitos que representa: essa função é do julgador, ao decidir pela procedência ou pela improcedência dos pedidos deduzidos. Aliás, nesse sentido inclusive aponta o Código de Ética e Disciplina do Conselho Federal da Ordem dos Advogados do Brasil, em seu art. 21, ao dispor ser "direito e dever do advogado assumir a defesa criminal, sem considerar sua própria opinião sobre a culpa do acusado".

No entanto, de acordo com o art. 8. ${ }^{\circ}$ do mesmo Código de Ética, “o advogado deve informar o cliente, de forma clara e inequívoca, quanto a eventuais riscos da sua pretensão, e das consequências que poderão advir da demanda". Portanto, especialmente nos casos envolvendo tão graves litígios familiares, o advogado tem o dever não apenas de proceder com toda a diligência possível para resguardar os interesses do seu cliente, mas, acima disso, alertá-lo acerca das possíveis consequências do litígio.

Além disso, conforme ditado pelo caput do seu art. 2. ${ }^{\circ}$, o Código de Ética determina ao advogado que subordine "a atividade do seu Ministério Privado à elevada função pública que exerce", e, nos incisos VI a VII do seu parágrafo único, que estimule "a conciliação entre os litigantes, prevenindo, sempre que possível, a instauração de litígios", bem como aconselhe "o cliente a não ingressar em aventura judicial”, e, ainda, que se abstenha "de emprestar concurso aos que atentem contra a ética, a moral, a honestidade e a dignidade da pessoa humana". Nesse sentido também dispõe o art. 20, ao estatuir que "o advogado deve abster-se de patrocinar causa contrária à ética, à moral ou à validade de ato jurídico em que tenha colaborado, orientado ou conhecido em consulta (...)”.

Afinal, o próprio Conselho Federal da OAB, no preâmbulo do Código de Ética e Disciplina, define como obrigação do advogado "ser fiel à verdade para poder servir à Justiça como um de seus elementos essenciais" (sem grifo no original), e "empenhar-se na defesa das causas confiadas ao seu patrocínio, dando ao constituinte o amparo do Direito, e proporcionando-lhe a realização prática de seus legítimos interesses" (sem grifo no original).

Proceder de acordo com o disposto nos dispositivos mencionados acima em nenhuma hipótese atenta contra a liberdade de atuação do advogado, nem muito menos contra os legítimos interesses do seu constituinte. Não se está defendendo a ideia de que o advogado deve, por exemplo, recusar patrocinar uma causa em que seu cliente pratique 
atos de alienação parental contra os filhos e o outro genitor. De forma alguma. Mesmo porque o advogado não é psicólogo, não é especialista na área da saúde mental, e portanto não possuiria condições de, mormente em fase tão inicial do litígio, verificar se seu cliente está ou não promovendo a alienação parental dos menores contra o outro genitor.

A observação que se faz, neste ponto, é que, principalmente em casos tão delicados como os envolvendo alienação parental - em que as consequências tendem a ser nefastas para todas as partes envolvidas, incluindo seu próprio cliente - o advogado deve proceder com extrema cautela, buscando aconselhar seu constituinte no sentido de alertá-lo não apenas para as consequências jurídicas que podem advir da sua derrota na demanda, mas também, e principalmente, do mal que eventualmente estará causando aos próprios filhos e até a si mesmo.

No litígio familiar o advogado invariavelmente atua como conselheiro, às vezes até mesmo como terapeuta do cliente. Empresta atenção às suas queixas, aos seus lamentos e desabafos. É importante, por isso, notadamente em casos de alienação parental, que promova o aconselhamento de forma franca e sincera, buscando evitar que a tragédia da desintegração familiar prejudique não apenas os filhos do seu cliente, mas, eventualmente, até este próprio.

\subsection{O papel do julgador}

Seja no juízo singular ou nos órgãos colegiados, o julgador, ao decidir questões relativas a conflitos familiares, deve se cercar de especial cuidado. Em muitos casos os aspectos patrimoniais são os menos relevantes na disputa que se instaura entre as partes, e não se pode esquecer que, via de regra, elas possuíram muito mais do que uma simples vinculação jurídica: viveram uma relação afetiva, íntima, e justamente por isso, capaz de suscitar, quando do seu término, as reações mais inesperadas, imprevisíveis e destrutivas.

Quando a disputa envolve a guarda e o direito de visitas em relação aos filhos comuns das partes, será necessária uma cautela ainda maior, pois dificilmente duas pessoas que tiveram de recorrer ao Judiciário para tentar resolver conflitos familiares possuirão o adequado grau de discernimento e de maturidade para compreenderem - e, principalmente, aceitarem - qualquer imposição que não lhes favoreça.

As atribuições do julgador, nas disputas familiares envolvendo a custódia dos filhos, são particularmente tormentosas: não se trata simplesmente de analisar uma relação contratual que apresenta o descumprimento de cláusulas, a ensejar esta ou aquela consequência jurídica. $\mathrm{O}$ que se discute é a mais íntima e particular relação entre pessoas - 
entre os ex-cônjuges ou companheiros, e entre cada um desses e os filhos. E ainda há que se levar em consideração que, por mais que as partes concordem ou discordem, a decisão final, no que concerne à guarda e ao regime de visitas, deve sempre levar em consideração, primeiramente, os interesses e o bem-estar dos filhos menores.

Não se cuida de tarefa simples mesmo para os profissionais das áreas da psicologia e do serviço social, por exemplo, que integram a equipe multidisciplinar - e que, portanto, são especializados em analisar as questões relativas ao âmbito familiar. A tarefa do julgador, que normalmente não possui conhecimento específico nessas searas, tende, portanto, a ser muito mais dificultosa.

Isso porque as relações familiares, tão intrínseca e profundamente humanas que são, trazem em sua natureza vicissitudes que muitas vezes ultrapassam a mera constatação do certo e do errado. Como destinatário final da prova no processo, o julgador terá de analisar todos os vieses, lapidando os elementos probatórios - auxiliado, sempre que necessário, pelos profissionais da equipe multidisciplinar - para que chegue, enfim, à melhor solução para a controvérsia. Lembrando, vez mais, que tal melhor solução, nos casos que envolvem os filhos menores das partes litigantes, será a solução que melhor prestigie os interesses destes, ainda que, eventualmente, prejudique os interesses das duas partes. Assim é que o julgador pode, numa ação de disputa pela guarda dos filhos, deixar de acolher o pedido das partes e atribuir a guarda a terceiro, se constatado que, naquele momento, nenhum dos genitores possui condições de exercer o múnus.

Portanto é de vital importância que o julgador sempre tenha em mente que, mormente quando existem filhos menores a compor a equação litigiosa, o conflito instaurado entre as partes tenderá a ser cruel, insensato e, muitas vezes, desmedido. Caberlhe-á, portanto, tomar quaisquer medidas que se mostrem necessárias - ainda que ao desagrado de ambas as partes - para a preservação do interesse dos menores.

A Lei da Alienação Parental, como se verá mais adiante, atribuiu amplos poderes ao julgador para que combata firmemente a conduta perniciosa daqueles que, intencionalmente ou não, colocam em risco direitos fundamentais da criança e do adolescente. A norma será, contudo, inócua se o julgador não chamar a si a responsabilidade de aplicá-la.

\subsection{O papel do Ministério Público}

Dentre as funções essenciais à Justiça destaca-se, também, a do Ministério Público. Consoante determina o art. 127 da CF/1988, “o Ministério Público é instituição 
permanente, essencial à função jurisdicional do Estado, incumbindo-lhe a defesa da ordem jurídica, do regime democrático e dos interesses sociais e individuais indisponíveis".

A intervenção do Ministério Público é obrigatória nas lides que envolvam os interesses de incapazes e o poder familiar (art. 82, I e II, do CPC), e é de sua competência “zelar pelo efetivo respeito aos direitos e garantias legais assegurados às crianças e adolescentes, promovendo as medidas judiciais e extrajudiciais cabíveis" (art. 201, VIII, do ECA).

Assim, ainda que atue como custos legis, compete-lhe ter vista dos autos depois das partes, sendo intimado de todos os atos do processo, e juntar documentos e certidões, produzir prova em audiência e requerer medidas ou diligências necessárias ao descobrimento da verdade (art. 83 do CPC).

Se nas lides que envolvam a disputa pela guarda e o direito de visitas a participação do Ministério Público é de primordial importância, com muito mais razão o será nos casos em que se verifique a possibilidade da ocorrência de alienação parental. A própria Lei 12.318/2010, no caput do seu art. 4. ${ }^{\circ}$, prevê a necessidade do juiz ouvir o Ministério Público para a adoção das "medidas provisórias necessárias para preservação da integridade psicológica da criança ou do adolescente, inclusive para assegurar sua convivência com genitor ou viabilizar a efetiva reaproximação entre ambos".

Tal participação é especialmente benéfica quando se leva em consideração que os representantes do parquet que atuam na área da Família e da Infância e Juventude, por sua experiência profissional e, muitas vezes, especialização acadêmica, podem contribuir decisivamente para a adequada solução do conflito familiar.

\subsection{O papel da equipe multidisciplinar e do assistente técnico}

O Código de Processo Civil elenca os peritos como profissionais que colaboram com a resolução das lides: são auxiliares da Justiça, conforme a dicção do art. 139.

Não é difícil vislumbrar a especial importância que a atuação de psicólogos, assistentes sociais, médicos psiquiatras, terapeutas e pedagogos desempenha na resolução dos conflitos familiares que chegam ao Judiciário. Trata-se de um âmbito que envolve elementos que, muitas vezes, ultrapassam aquilo que ordinariamente é alcançado pelo domínio dos julgadores. Não raro, portanto, que para poder fundamentar adequadamente suas decisões, o julgador lance mão do auxílio de tais profissionais especializados nas mais diferentes áreas do conhecimento. 
Especificamente nos casos de disputa por guarda, as perícias terão destaque especial, face à necessidade de se identificar qual genitor possui melhores condições de proporcionar aos filhos um ambiente saudável, afetuoso e que garanta a efetividade dos princípios do melhor interesse e da proteção integral.

O perito assistente social, por exemplo, deverá atentar para a relação objetiva entre os genitores e os filhos, ou seja, a estrutura familiar instaurada entre eles. Assim, deverá analisar aspectos relacionados ao ambiente familiar, à residência, ao trabalho, ao acompanhamento médico e escolar, enfim, às condições do ambiente que os genitores podem oferecer aos filhos.

O perito psicólogo, por seu turno, deverá averiguar aspectos mais subjetivos atinentes tanto ao relacionamento entre os genitores e os filhos, mas também à viabilização, pelo genitor guardião, do convívio familiar dos filhos com o genitor descontínuo. Especialmente nos casos de alienação parental, a figura do psicólogo - e eventualmente até do psiquiatra - será de grande importância. Segundo acuradamente apontam DOUGLAS PHILLIPS FREITAS e GRACIELA PELLIZZARO,

Quando constatada na lide a presença de Alienação Parental, e precisando o juiz determinar quem tem melhores condições psicológicas para ter ou manter a guarda, o objeto a ser periciado são as questões que fogem à objetividade da realidade e estrutura social da família, em que, pela necessidade de se vislumbrarem os impactos e as questões subjetivas envolvidas, urge o chamamento do profissional da psicologia para atuação nessas situações ${ }^{254}$.

O psicólogo estará em contato direto com as partes do conflito, ouvindo todas as versões e, mais que isso, analisando-as com os filtros que seu conhecimento específico e sua experiência no trato de casos similares lhe fornecem. Nesse sentido, tratando das medidas que podem ser tomadas para se prevenir ou reverter situações de alienação parental, JANELLE BURRILL aponta que:

Para considerar a adoção de adequadas soluções terapêuticas e legais, é preciso primeiramente definir especificamente o tipo particular de distúrbio antes de considerar as várias opções de tratamento. $\mathrm{O}$ fracasso em fazer a diferenciação entre Alienação Parental e Síndrome da Alienação Parental resultará em soluções terapêuticas e legais equivocadas ${ }^{255}$.

254 FREITAS, Douglas Phillips; PELLIZZARO, Graciela. Alienação parental: comentários à Lei 12.318/2010. Rio de Janeiro: Ed. Forense, 2011, p. 20.

${ }^{255}$ BURRILL, Janelle. Reluctance to verify PAS as a legitimate syndrome. In: GARDNER, Richard A.; LORANDOS, Demosthenes; SAUBER, S. Richard (org.) The International Handbook of Parental Alienation Syndrome. 2nd ed. Springfield, IL : Charles C Thomas Publisher LTD, 2006, p. 325. Tradução livre de: “To 
Por isso, notadamente nos casos envolvendo alienação parental - em que as atitudes, as intenções, e os comportamentos e podem ser oblíquos, velados e dissimulados - a intervenção desse profissional será indispensável para permitir o adequado convencimento do julgador. O próprio art. 6. ${ }^{\circ}, \mathrm{IV}$, da Lei da Alienação Parental faculta ao juiz que determine acompanhamento biopsicossocial quando constatada a prática dos atos alienadores.

Os assistentes técnicos, por sua vez, conforme enunciado pelo art. 421 do CPC, são profissionais indicados (e contratados) pelas partes, caso queiram, para que, além de formularem quesitos aos peritos judiciais, apresentem seus próprios pareceres acerca da controvérsia.

É importante ressaltar que, por mais bem conceituados que sejam os assistentes técnicos indicados pelas partes, deve sempre ser levado em consideração, pelo julgador, que seus pareceres não podem, sob qualquer hipótese, servir, sozinhos, para a fundamentação da decisão. Podem - e devem - servir subsidiariamente aos laudos produzidos pelos peritos judiciais, que são partes presumidamente isentas e imparciais.

8.6. Lei 12.318/2010 - Lei da Alienação Parental - muitos elogios, algumas críticas e uma proposta

Apresentado pelo deputado Régis de Oliveira, o projeto de lei 4.053 de 2008, dispondo sobre a alienação parental, foi transformado na Lei 12.318, de 26 de agosto de 2010, sancionada pelo Presidente após o veto de dois artigos.

A norma, no caput do seu art. 2. ${ }^{\circ}$, define o que é considerado ato de alienação parental, elencando algumas formas exemplificativas de alienação no parágrafo único:

Art. 2. ${ }^{\circ}$ Considera-se ato de alienação parental a interferência na formação psicológica da criança ou do adolescente promovida ou induzida por um dos genitores, pelos avós ou pelos que tenham a criança ou adolescente sob a sua autoridade, guarda ou vigilância para que repudie genitor ou que cause prejuízo ao estabelecimento ou à manutenção de vínculos com este.

Parágrafo único. São formas exemplificativas de alienação parental, além dos atos assim declarados pelo juiz ou constatados por perícia, praticados diretamente ou com auxílio de terceiros:

I - realizar campanha de desqualificação da conduta do genitor no exercício da paternidade ou maternidade;

even consider proper therapeutic and legal remedies, one must first define specifically the client's particular type of disorder before one can properly consider the various treatment options. Failure to make the differentiation between PA and PAS will result in inappropriate therapeutic treatment and/or legal remedies". 
II - dificultar o exercício da autoridade parental;

III - dificultar contato de criança ou adolescente com

IV - dificultar o exercício do direito regulamentado de convivência familiar;

$\mathrm{V}$ - omitir deliberadamente a genitor informações pessoais relevantes sobre a criança ou adolescente, inclusive escolares, médicas e alterações de endereço;

VI - apresentar falsa denúncia contra genitor, contra familiares deste ou contra avós, para obstar ou dificultar a convivência deles com a criança ou adolescente;

VII - mudar o domicílio para local distante, sem justificativa, visando a dificultar a convivência da criança ou adolescente com o outro genitor, com familiares deste ou com avós.

Prudentemente, cercou-se o legislador de cuidados ao elencar, em caráter meramente exemplificativo, exemplos de conduta que, praticadas por genitores, avós ou por quem tenha a criança ou adolescente sob a sua autoridade, guarda ou vigilância (incluindo-se, portanto, tutores e curadores, demais parentes e até mesmo eventual novo companheiro do genitor alienador), com o intuito de que o menor repudie genitor, ou prejudicando o estabelecimento ou a manutenção de laços afetivos entre os filhos e genitor, caracterizam atos de alienação parental.

Vale notar que a norma não traz critérios excludentes para a verificação da conduta do alienador: a prática de atos com o intuito de que o menor repudie genitor (portanto necessitando demonstrar a finalidade específica da conduta, ainda que de maneira indireta) é caracterizadora de alienação parental; também o é a simples conduta que cause prejuízo ao estabelecimento ou à manutenção de vínculos entre o filho e o genitor. O legislador conferiu, portanto, juízo de desvalor tanto à conduta de visar a obstrução da convivência familiar, como ao resultado de alcançar tal obstrução, ainda que não tenha havido a intenção específica de se perpetrá-la.

Art. 3. ${ }^{\circ}$ A prática de ato de alienação parental fere direito fundamental da criança ou do adolescente de convivência familiar saudável, prejudica a realização de afeto nas relações com genitor e com o grupo familiar, constitui abuso moral contra a criança ou o adolescente e descumprimento dos deveres inerentes à autoridade parental ou decorrentes de tutela ou guarda.

Andou bem, mais uma vez, o legislador ao, no texto deste art. $3 .^{\circ}$, expressamente consignar que a prática de atos de alienação parental constitui abuso moral contra a 
criança ou o adolescente. É o quanto basta para admitir que, sem dúvida, cabe a persecução de compensação por danos morais decorrentes da conduta alienadora ${ }^{256}$.

Ainda mais relevante que a previsão expressa da configuração de abuso moral contra o menor, a parte final do mencionado dispositivo caracteriza a prática de atos de alienação parental também como descumprimento dos deveres inerentes à autoridade parental ou decorrentes de tutela ou guarda.

É de se lembrar o disposto no arts. 24 e 22 da Lei 8.069/1990, o Estatuto da Criança e do Adolescente:

Art. 24. A perda e a suspensão do poder familiar serão decretadas judicialmente, em procedimento contraditório, nos casos previstos na legislação civil, bem como na hipótese de descumprimento injustificado dos deveres e obrigações a que alude 0 art. 22.

Art. 22. Aos pais incumbe o dever de sustento, guarda e educação dos filhos menores, cabendo-lhes ainda, no interesse destes, a obrigação de cumprir e fazer cumprir as determinações judiciais (sem grifo no original).

Percebe-se, portanto, que, constatada a prática de ato de alienação parental, e advertido o alienador (art. 6. ${ }^{\circ}$, I, da Lei 12.318/2010), a insistência na conduta alienadora configura claro descumprimento de determinação judicial (art. 22 do ECA), o que, por sua vez, enquadra-se nas hipóteses de perda e suspensão do poder familiar (art. 24 do ECA).

Dessa forma, muito embora a Lei de Alienação Parental determine apenas a possibilidade de suspensão da autoridade parental (art. 6. ${ }^{\circ}$, VII), parece perfeitamente plausível a eventual aplicação da pena de perda do poder familiar - se tal medida de fato for necessária à proteção dos melhores interesses dos filhos menores. A possibilidade da sua aplicação, contudo, deve servir de maneira eficaz como forma de advertência ao genitor que pratica atos de alienação parental.

Art. 4..$^{\circ}$ Declarado indício de ato de alienação parental, a requerimento ou de ofício, em qualquer momento processual, em ação autônoma ou incidentalmente, o processo terá tramitação prioritária, e o juiz determinará, com urgência, ouvido o Ministério Público, as medidas provisórias necessárias para preservação da integridade psicológica da criança ou do adolescente, inclusive

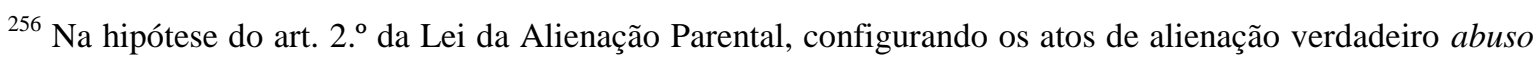
moral contra a criança e o adolescente, não incluiu, o legislador, o genitor alienado como a outra necessária vítima da alienação parental. Propõe-se, adiante, a precisão expressa de violação também ao patrimônio moral do genitor-alvo da alienação parental, de forma a legitimá-lo pessoalmente à persecução de compensação por danos extrapatrimoniais.
} 
para assegurar sua convivência com genitor ou viabilizar a efetiva reaproximação entre ambos, se for o caso.

Parágrafo único. Assegurar-se-á à criança ou adolescente e ao genitor garantia mínima de visitação assistida, ressalvados os casos em que há iminente risco de prejuízo à integridade física ou psicológica da criança ou do adolescente, atestado por profissional eventualmente designado pelo juiz para acompanhamento das visitas.

Prevê a lei, dessa forma, que a iniciativa para a averiguação da ocorrência de alienação parental, em decorrência de suficientes indícios, não é apenas da parte que sofre a alienação (por advogado próprio ou por meio da assistência judiciária): o Ministério Público, como custos legis (art. 82, I e II, do CPC, e arts. 127, caput, e 129, IX, da $\mathrm{CF} / 1988$ ) pode provocar o juízo à averiguação da ocorrência de alienação parental $^{257}$; e o próprio julgador, de ofício, em quaisquer momento e grau de jurisdição, pode declarar a existência de tais indícios, o que automaticamente confere tramitação prioritária ao processo - o que é absolutamente necessário, pois, verificada realmente a prática da alienação parental, são de extrema urgência as medidas a serem tomadas pelo juízo no sentido de evitar maior prejuízo à criança e ao genitor alienado.

Cumpre indicar, ainda, que a declaração da existência de indícios de alienação parental, conforme determina o caput deste art. $4 .^{\circ}$, pode se dar em ação autônoma visando especificamente tal declaração, ou mesmo incidentalmente a ações em que esteja se discutindo a guarda e/ou a regulamentação do regime de visitas ${ }^{258}$. Comumente, contudo, a alienação parental inicia-se após o estabelecimento da guarda e do regime de visitas, quando o alienador, então, passará a obstaculizar a convivência dos filhos com o genitor alienado.

\footnotetext{
257 "Medida de proteção intentada pelo Ministério Público em favor de menores. Síndrome de alienação parental. Interesse de menores. Legitimidade. Competência da vara da infância e da juventude. Reconhecimento. Decisão que arquivou o feito. Descabimento. Reforma. 1. Tendo em vista o disposto nos artigos 141 e 201, VIII, da Lei $n^{\circ} 8.069 / 1990 \mathrm{c} / \mathrm{c}$ artigo 82, I, do CPC, o Ministério Público tem legitimidade para figurar no pólo ativo de ação em que se pleiteia a adoção de medidas protetivas contra alienação parental. 2. Conjugando-se o disposto no artigo 98 , II, com as determinações do artigo 148 , $\S$ único, $d$, ambos do ECA, tem-se a competência do juízo da infância e da juventude para conhecer, processar e julgar medida de regulamentação de visita, que busca coibir alienação parental promovida pela mãe contra o pai. 3. Impõe-se a reforma da decisão que determinou o arquivamento dos autos em que se pleiteou medida protetiva para menores, se restar verificado a plausibilidade de eles estarem em situação de risco, especificamente em síndrome de alienação parental. 4. Recurso provido" (sem grifo no original) (TJMG. ApCiv 1.0114.10.014405-3/001. 8. ${ }^{\mathrm{a}}$ Câm Cív., rel. Des. Vieira de Brito. J. 26.05.2011. v.u.).

258 "Processual civil - Civil - Família - Alienação parental - Pedido incidente - Possibilidade. 1. É cabível a instauração de incidente de alienação parental, a qualquer tempo, em ação autônoma ou incidentalmente, em observância ao princípio da proteção integral do menor. 2. Recurso provido" (TJDFT. AgIn 20100020198441 AGI. 3. ${ }^{a}$ Turma Cív., rel. Des. João Mariosi. J. 27.04.2011. v.u.).
} 
Quando a lei atribui ao juiz a determinação urgente de medidas provisórias necessárias à preservação da integridade psicológica da criança e do adolescente, abre possibilidade, por exemplo, para a urgente determinação de acompanhamento psicossocial dos menores, bem como, sendo necessário, o afastamento temporário do alienador.

E, ao buscar assegurar o convívio do menor com o genitor alienado, visando estabelecer ou restabelecer seus laços afetivos, poderá o julgador determinar a ampliação do regime de visitas, que, de acordo com o parágrafo único deste mesmo dispositivo, já é garantido ao mínimo, de forma assistida, se necessário, e desde que o contato do menor com o genitor alienado não seja passível de agravar ainda mais a integridade física ou psicológica do filho.

Ocorre que, não raro, e especialmente quando a alienação parental já ultrapassou os atos iniciais e possivelmente se transformou na síndrome da alienação parental, a programação sofrida pelo menor é tamanha que, ainda que injustificadamente, a criança ou o adolescente demonstra verdadeiro pânico em relação ao genitor alienado. Há ocorrências, não apenas constantes da literatura especializada, mas também da jurisprudência pátria ${ }^{259}$, em que o transtorno psicológico sofrido pelo menor vítima da síndrome da alienação parental é tão grave que a manutenção da convivência entre a criança e o genitor alienado serviria apenas para agravar ainda mais os danos já produzidos aos laços afetivos entre ambos. Nessas hipóteses em que, além de verificada a impossibilidade temporária de manutenção da convivência familiar entre o menor e o genitor-alvo, constata-se a prática de alienação parental, imperioso retirar a criança do convívio do alienador, bem como submetê-la a adequado tratamento psicossocial.

Art. 5. ${ }^{\circ}$ Havendo indício da prática de ato de alienação parental, em ação autônoma ou incidental, o juiz, se necessário, determinará perícia psicológica ou biopsicossocial.

§ 1. O laudo pericial terá base em ampla avaliação psicológica ou biopsicossocial, conforme o caso, compreendendo, inclusive, entrevista pessoal com as partes, exame de documentos dos autos, histórico do relacionamento do casal e da separação,

\footnotetext{
${ }^{259}$ Nesse sentido, conferir o seguinte acórdão: "Guarda. Superior interesse da criança. Síndrome da alienação parental. Havendo na postura da genitora indícios da presença da síndrome da alienação parental, o que pode comprometer a integridade psicológica da filha, atende melhor ao interesse da infante, mantê-la sob a guarda provisória da avó paterna. Negado provimento ao agravo. (...) Os laudos juntados, por assistente social e psicóloga, denotam um abuso psicológico da menina por parte de sua mãe. Há, então, de forma concreta, um abuso da filha pela requerida (...). É patente que este abuso está colocando em risco a saúde emocional da infante (...). Em decorrência das temerosas atitudes apresentadas pela genitora na condição de guardiã, e em atenção ao princípio do melhor interesse da criança, mostra-se razoável que, por ora, a guarda seja mantida com a avó paterna" (sem grifo no original) (TJRS. AgIn 70014814479. 7. a Câm. Cív., rel. Des. Maria Berenice Dias. J. 07.06.2006. v.u.).
} 
cronologia de incidentes, avaliação da personalidade dos envolvidos e exame da forma como a criança ou adolescente se manifesta acerca de eventual acusação contra genitor.

§ 2.․ A perícia será realizada por profissional ou equipe multidisciplinar habilitados, exigido, em qualquer caso, aptidão comprovada por histórico profissional ou acadêmico para diagnosticar atos de alienação parental.

$\S 3 .^{\circ} \mathrm{O}$ perito ou equipe multidisciplinar designada para verificar a ocorrência de alienação parental terá prazo de 90 (noventa) dias para apresentação do laudo, prorrogável exclusivamente por autorização judicial baseada em justificativa circunstanciada.

A realização de perícia psicossocial em casos envolvendo abuso de autoridade parental, mormente quando a discussão envolve a modificação da guarda e a alteração do regime de visitas, já era medida tomada pelo Judiciário ${ }^{260}$. E, especificamente nos casos em que há indícios de alienação parental a perícia psicológica ou biopsicossocial é de extrema importância e urgência, conforme enfatiza PRISCILA MARIA P. CORRÊA DA FONSECA:

É imperioso que os juízes se deem conta dos elementos identificadores da alienação parental, determinando, nestes casos, rigorosa perícia psicossocial para, aí então, ordenar as medidas necessárias para a proteção do infante. Observe-se que não se cuida de exigir do magistrado - que não tem formação em Psicologia - o diagnóstico da alienação parental. Contudo, o que não se pode tolerar é que, diante da presença de seus elementos identificadores, não adote o julgador, com urgência máxima, as providências adequadas, dentre as quais o exame psicológico e psiquiátrico das partes envolvidas $^{261}$.

A Lei da Alienação Parental, neste art. 5. ${ }^{\circ}$, trata, portando, do aspecto probatório: justamente por não possuir, o julgador, arcabouço técnico específico para identificar, com o grau de certeza que se faz necessário, a prática de atos de alienação - nem tampouco dos sintomas caracterizadores da síndrome da alienação parental -, a participação de profissionais especializados, aptos a verificar a ocorrência de alienação, é imprescindível $^{262}$.

\footnotetext{
${ }^{260}$ Nesse sentido, conferir o seguinte acórdão: "Medida protetiva - Inversão de guarda de menor - Guarda concedida ao genitor - Realização de estudo psicossocial - Decisão mantida - Recurso desprovido" (TJMT.

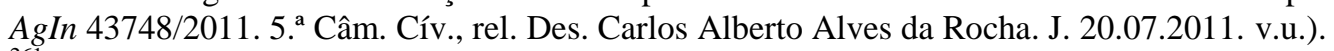

${ }^{261}$ FONSECA, Priscila Maria P. Corrêa. Síndrome da alienação parental. In: Revista Brasileira de Direito de Família, n. 40, fev./mar. 2007, p. 14.

${ }^{262}$ Nesse sentido, conferir o seguinte acórdão: "Direito de família. Ação de guarda ajuizada pelo genitor em face da avó materna. Pedido de realização de perícia social, em detrimento de estudo social, indeferido pelo juízo a quo. Pertinência e relevância da prova reclamada. Necessidade de instrução ampla e irrestrita, inclusive com a realização da postulada perícia. Visitas do filho ao pai fixadas em três finais de semana ao mês. Nova decisão interlocutória versando sobre a matéria impugnada. Perda do objeto, no tópico.
} 
Assim, de acordo com o $\S 1 .^{\circ}$ do dispositivo em comento, o laudo pericial deve lastrear-se em ampla gama de elementos probatórios, inclusive - e principalmente - na entrevista pessoal com as partes. Este é um ponto chave, pois, via de regra, as partes envolvidas num processo pela disputa da guarda dos filhos, especialmente em que existe a acusação de alienação parental, tendem a fornecer ao julgador uma profusão de pareceres técnicos, que, a despeito de no mais das vezes serem produzidos por profissionais habilitados e de renome, tenderão, via de regra, a acolher e privilegiar a visão da parte que contratou o assistente técnico.

Não se está questionando a honestidade e a ética dos profissionais que atuam como assistentes técnicos. Sua participação é muito importante, inclusive, e principalmente, no momento da formulação de quesitos a serem respondidos pela perícia judicial. Contudo, como são contratados pelas partes, dificilmente terão a oportunidade de obter um panorama geral, abrangente, que albergue a situação conflituosa como um todo, já que dificilmente uma parte aceitará se submeter à análise dos assistentes da parte contrária. Além disso, é preciso não se incorrer no erro ingênuo de presumir que, ainda que o assistente não vá falsear a verdade em favor do seu cliente, não irá, ao menos, deixar de apontar determinadas informações que ao perito judicial não passariam tão “desapercebidas". Não são incomuns os casos em que os assistentes técnicos produzem pareceres e mais pareceres com base apenas em dados do processo, e basear-se o julgador em tais pareceres para proferir qualquer decisão, sem apoiar-se em laudo pericial oficial, seria conduta por demais temerária.

Nesse sentido, o legislador exigiu, no $\S 2 .^{\circ}$ do art. $5^{\circ}$, que os profissionais que levarão a cabo a perícia biopsicossocial sejam não apenas habilitados pelos conselhos profissionais, mas também que possuam comprovada aptidão, por histórico profissional ou acadêmico, para reconhecer atos de alienação parental. Não basta, portanto, que os mencionados peritos atuem em suas áreas há muito tempo, nem que possuam extensa qualificação acadêmica através de pós-graduações, especializações, etc. É necessário que

Interlocutório parcialmente reformado. Recurso parcialmente provido" (sem grifo no original) (TJSC. AgIn 2010.050581-7. 3. ${ }^{a}$ Câm. de Direito Civil., rel. Des. Marcus Tulio Sartorato. J. 15.03.2011. v.u.); e ainda: “Ação de guarda - Indícios de alienação parental - realização de perícia - preservação do bem estar do menor. Com fulcro na Lei 12.318/2010, havendo nos autos indícios da ocorrência da prática de ato de alienação parental, o juiz pode determinar a realização de perícia psicológica ou biopsicossocial, a fim de se aproximar da verdade real, e, assim, obter novas condições para escolher o melhor guardião para a criança. A melhor doutrina e a atual jurisprudência, inclusive deste próprio tribunal, estão assentadas no sentido de que, em se tratando de guarda de menor, 'o bem estar da criança e a sua segurança econômica e emocional devem ser a busca para a solução do litígio' (Agravo 234.555-1, acórdão unânime da 2a Câmara Cível, TJMG, relator Des. Francisco Figueiredo, pub. 15/03/2002). Recurso provido" (sem grifo no original) (TJMG. AgIn 1.0024.09.644906-1/003. 1. ${ }^{a}$ Câm. Cív., rel. Des. Eduardo Andrade. J. 12.04.2011. v.u.). 
detenham conhecimento específico sobre alienação parental. Assim, muito embora a exigência seja salutar, por permitir ao julgador que tenha uma maior confiança no diagnóstico da perícia, vislumbra-se a ocorrência de inúmeros questionamentos acerca da capacidade técnica da equipe biopsicossocial, pelas partes envolvidas no processo, com o único propósito de procrastinar a decisão do julgador que reconhece a ocorrência de atos de alienação parental.

O prazo para que o perito ou a equipe multidisciplinar apresentem o laudo é de 90 dias, podendo ser prorrogado em caso de necessidade extrema. Verifica-se uma maior preocupação do legislador com a brevidade do procedimento, visando proteger os interesses dos menores, uma vez que, conforme se mencionou, o fator tempo é um grande contribuidor para a instalação da síndrome da alienação parental. Por isso a prorrogação do prazo exige expressa autorização judicial, por meio de justificativa através da qual o magistrado exponha os motivos que o levaram a conceder o acréscimo de prazo.

Art. 6. ${ }^{\circ}$ Caracterizados atos típicos de alienação parental ou qualquer conduta que dificulte a convivência de criança ou adolescente com genitor, em ação autônoma ou incidental, o juiz poderá, cumulativamente ou não, sem prejuízo da decorrente responsabilidade civil ou criminal e da ampla utilização de instrumentos processuais aptos a inibir ou atenuar seus efeitos, segundo a gravidade do caso:

Neste art. 6. ${ }^{\circ}$ da Lei da Alienação Parental o legislador buscou estabelecer formas de combater a prática e os efeitos da alienação parental. Interessante notar que, de maneira expressa, o texto legal o não esgotamento, na presente lei, das medidas aplicáveis quando da caracterização de atos típicos de alienação parental ou outra conduta que dificulte a convivência de criança ou adolescente com genitor.

Mencionou-se, textualmente, as responsabilidades civil e penal eventualmente cabíveis no caso concreto. Insta consignar que, ao menos, a responsabilização civil poderá se dar por meio da obrigação de compensar os danos materiais e morais, tanto na esfera do menor quanto na do genitor alienado, e a responsabilização criminal poderá ocorrer através do crime de desobediência (art. 330 do CP), quando houver expressa determinação judicial para que o genitor alienador faça ou se abstenha de praticar determinada conduta, e ainda assim a ordem for descumprida ${ }^{263}$.

${ }^{263}$ Tratando-se de sanção penal, estreme de dúvidas que a averiguação da conduta deverá ser realizada de forma ampla e exaustiva. Nesse sentido, o seguinte julgado: "Regulamentação de visitas - Condições impostas ao pai - Eventual recusa de entregar as crianças no dia da visita paterna deve ser analisada com 
Nos incisos do artigo em comento, o legislador estabeleceu um rol - meramente exemplificativo - de medidas cabíveis, alternativa ou cumulativamente, em caso de alienação parental:

I - declarar a ocorrência de alienação parental e advertir o alienador;

Devendo ser levado em consideração que, não raro, o alienador pratica os atos de alienação sem a intenção específica de perpetrar abuso moral contra o menor, alijando-o do convívio familiar com o genitor alienado, a advertência deve ser a primeira medida a ser tomada pelo magistrado.

II - ampliar o regime de convivência familiar em favor do genitor alienado;

A prescrição de se ampliar o período de convivência entre o menor e o genitor alienado é salutar, pois visa minimizar e reverter os efeitos da alienação parental, desconstituindo a programação efetivada pelo alienador com o intuito de prejudicar a relação de afeto entre o genitor-alvo e o menor.

Contudo, repisa-se, nem sempre a adoção de tal medida é possível ou aconselhável. Por vezes, a depender do grau de alienação sofrido pelo menor, será necessário que a convivência entre as partes ocorra de forma assistida, com gradual expansão, traduzindo-se a mera ampliação do regime de convivência em medida que, na verdade, acabará por prejudicar ainda mais a relação afetiva entre o genitor alienado e o menor.

$$
\text { III - estipular multa ao alienador; }
$$

$\mathrm{O}$ art. 461, $\S 5^{\circ}$, do CPC, traz os parâmetros a serem utilizados no caso de se demonstrar necessária a aplicação de multa ao alienador, e, portanto, é aplicável na busca da efetivação da tutela específica ou na obtenção do resultado prático equivalente.

Dessa forma, em caso de descumprimento de quaisquer das ordens impostas pelo julgador - como de não obstrução da convivência entre o genitor e os filhos, não 
difamação do genitor descontínuo, etc. -, caberá a aplicação das astreintes, de forma tal que sirva, de fato, ao propósito de dissuadir o alienador da prática de atos de alienação ${ }^{264}$. biopsicossocial;

IV - determinar acompanhamento psicológico e/ou

O acompanhamento por profissionais especializados em conflitos desta espécie pode ser determinado pelo juiz ${ }^{265}$. Importa ressaltar que não apenas o menor alienado, mas também - e principalmente - o alienador poderá ter de se sujeitar a tal acompanhamento psicológico ou biopsicossocial.

Pode-se questionar acerca da efetividade de um tratamento realizado "à força", levando-se em consideração ainda o fato de que, por vezes, o alienador realmente acredita não estar fazendo nada de errado, por não conseguir dissociar a figura do ex-cônjuge da figura do genitor.

Vale apontar, contudo, que muitas vezes a realização de acompanhamento psicológico pode, principalmente nesses casos em que o alienador não encara a própria conduta como reprovável, esclarecer a complexidade da situação, levando o alienador a compreender que nada de bom advirá da sua conduta, muito pelo contrário. Se durante algum tempo ele terá o apoio ostensivo dos filhos alienados, quando estes alcançarem certo nível de maturidade e capacidade de compreensão daquilo por que passaram, tenderão a rechaçar o alienador, ainda que não passem necessariamente a aceitar o genitor alienado. Quando se derem conta da gravidade da conduta alienadora, e de todo o prejuízo que ela lhes causou, os filhos alienados poderão até mesmo se afastar do genitor alienador.

Com relação ao acompanhamento obrigatório, por determinação judicial, dos menores vítimas da alienação, o mesmo raciocínio se aplica, sendo que, nessa hipótese, as

\footnotetext{
${ }^{264}$ Nesse sentido, conferir o seguinte julgado: "Agravo de instrumento. Ação de execução de fazer. Imposição à mãe/guardiã de conduzir o filho à visitação paterna, como acordado, sob pena de multa diária. Indícios de síndrome de alienação parental por parte da guardiã que respalda a pena imposta. Recurso conhecido em parte e desprovido" (sem grifo no original) (TJRS. AgIn 70023276330. 7. a Câm. Cív., rel. Des. Ricardo Raupp Ruschel. J. 18.06.2008. v.u.).

${ }^{265}$ Nesse sentido, conferir o seguinte julgado: "Agravo de instrumento. Ação de reversão de guarda com pedido de antecipação da tutela. Guarda da filha revertida liminarmente. Recurso interposto pela genitora (mãe). Alegação de alcoolismo e violência por parte do genitor (pai) contra a menor. Conduta não verificada. Indícios de alienação parental por parte da mãe e de sua companheira não configurada extreme de dúvidas. Necessidade de acompanhamento familiar e de tratamento psicológico dos pais para assegurar relacionamento que propicie um exercício saudável da guarda e do direito de visitação. Momento processual que inspira cautela. Manutenção da guarda com a mãe que, não obstante, deve ser advertida da importância do convívio do genitor com a infante. Decisão que preserva o melhor interesse da criança. Inteligência dos artigos 129, III da Lei 8.069/90 e 6. ${ }^{\circ}$, IV da Lei 12.318/2010. Recurso conhecido e provido" (sem grifo no original) (TJSC. AgIn 2011.017910-3. 6. ${ }^{a}$ Câm. de Direito Civil., rel. Des. Ronei Danielli. J. 28.07.2011. v.u.).
} 
chances de obtenção de sucesso em reverter a alienação e seus efeitos são ainda maiores. Parece, contudo, que pouca ou nenhuma efetividade terá a medida de submeter os menores a acompanhamento psicológico ou biopsicossocial se as condutas alienadoras continuarem a ocorrer. Será preciso, assim, ou submeter também o alienador a tratamento, ou afastar os menores da sua influência deletéria.

V - determinar a alteração da guarda para guarda compartilhada ou sua inversão;

Por vezes apenas a advertência, a aplicação de multa cominatória, e mesmo a submissão forçada a tratamento psicológico não serão medidas suficientes para dissuadir o genitor da conduta alienadora. Por isso este inciso $\mathrm{V}$ trouxe a previsão de uma medida mais drástica: a modificação da guarda dos filhos.

Dessa forma, poderá o juiz alterar a guarda unilateral, até então atribuída ao alienador, convertendo-a em guarda compartilhada. Não se vislumbra, contudo, a viabilidade prática de tal modificação. Ora, se o nível de animosidade do conflito instalado entre os genitores chegou ao patamar de se considerar - após as advertências, a imposição de multas e a submissão do alienador a tratamento psicológico - alterar a guarda, parece óbvio que a forma compartilhada, que pressupõe o entendimento dos genitores quanto ao exercício do poder familiar, será virtualmente impossível.

Não se nega, de forma alguma, que a guarda compartilhada seja uma - boa - forma de se prevenir a ocorrência da alienação parental. De fato é, dado o permanente compartilhamento da autoridade parental em sua totalidade, o que diminui o campo de ação de um potencial alienador. Contudo, também não se pode negar que, quando o conflito entre os genitores é por demais acirrado, o próprio Código Civil prevê a não preferência pelo compartilhamento da guarda, uma vez que os genitores não conseguem sequer estabelecer uma relação minimamente cordial entre si, que dirá com relação à tomada diária de decisões sobre a educação e a criação dos filhos.

Quanto à inversão da guarda, ela pode, sim, ser uma medida eficaz. Mas é preciso que o julgador tenha muita cautela ao decidir por inverter a guarda dos filhos alienados em favor do genitor-alvo. Conforme já se afirmou, muitas vezes a alienação parental, através da programação e da implantação de falsas memórias, já produziu efeitos tão devastadores nas crianças que elas não aceitam, sob nenhuma hipótese, ficar na companhia - que dirá sob a guarda - do genitor alienado, ainda que este jamais tenha contribuído de qualquer maneira para a existência de tamanha rejeição. Nesses casos mais graves - em que, por 
vezes, as crianças chegam a sofrer sérias crises nervosas ante a mera possibilidade de terem de passar a viver com o genitor alienado - a inversão da guarda será impossível. Não traria benefício algum à relação entre o genitor-alvo e os filhos, pelo contrário.

Portanto, muito embora essa possibilidade se encontre no art. $1.584, \S 5 .^{\circ}$, do $\mathrm{CC} / 2002$, o legislador teria feito bem em incluir, ao final deste inciso, a possibilidade de o juiz, em vez de decretar a guarda compartilhada ou a sua inversão, deferi-la "à pessoa que revele compatibilidade com a natureza da medida, considerados, de preferência, o grau de parentesco e as relações de afinidade e afetividade". A depender da gravidade dos efeitos já sofridos pelos filhos em decorrência da conduta alienadora, a atribuição da sua guarda a terceiros - associada ao seu (bem como do alienador) acompanhamento seu psicológico será a única forma eficaz de se solucionar o conflito. ou adolescente;

VI - determinar a fixação cautelar do domicílio da criança

Comumente se observa, em meio à disputa pela guarda dos filhos, diversas alterações de domicílio por parte do guardião, com o claro objetivo de embaraçar as determinações judiciais.

Assim, de acordo com o disposto neste inciso VI, faculta-se ao julgador que, em caráter cautelar, fixe o domicílio do menor, com o intuito de estabelecer um local determinado onde tramitará o processo, ainda que haja alteração física de residência por parte do guardião.

VII - declarar a suspensão da autoridade parental.

“Autoridade parental”, aqui, trata do instituto jurídico do poder familiar. Dessa forma, este inciso aumenta o rol de hipóteses de suspensão do poder familiar. Segundo o caput do art. 1.637 do CC/2002,

Se o pai, ou a mãe, abusar de sua autoridade, faltando aos deveres a eles inerentes ou arruinando os bens dos filhos, cabe ao juiz, requerendo algum parente, ou o Ministério Público, adotar a medida que the pareça reclamada pela segurança do menor e seus haveres, até suspendendo o poder familiar, quando convenha (sem grifo no original).

Não se pode negar que a prática de atos de alienação parental, que obstruem o fundamental direito do menor à convivência familiar com ambos os genitores, configura espécie de abuso do poder familiar, por faltar com os deveres inerentes às figuras paterna 
ou materna. Dessa maneira, ainda que a Lei da Alienação Parental não tivesse trazido tal dispositivo, o julgador já possuiria autorização para aplicar a suspensão do poder familiar.

Vale lembrar, ainda, que segundo o art. 22 da Lei 8.069/1990 (ECA), aos pais cabe, no interesse dos filhos menores, a obrigação de cumprir e fazer cumprir as determinações judiciais. Assim, reconhecido por decisão judicial o direito do genitor não-guardião de manter com seus filhos menores a convivência familiar, através, pro exemplo, dos períodos de visita, a obstrução de tal convivência viola frontalmente o disposto no art. 22 do ECA, e a penalidade para tal violação vem explicitada no art. 24 do estatuto:

Art. 24. A perda e a suspensão do poder familiar serão decretadas judicialmente, em procedimento contraditório, nos casos previstos na legislação civil, bem como na hipótese de descumprimento injustificado dos deveres e obrigações a que alude $o$ art. 22.

Portanto, também o ECA já trazia solução a permitir a suspensão do poder familiar do genitor que, abusando da autoridade parental que lhe foi conferida através da guarda, obstaculiza ou mesmo impede o exercício do direito que os filhos menores, bem como o genitor descontínuo, possuem à convivência familiar.

Este dispositivo da Lei da Alienação Parental, contudo, silenciou-se quanto à possibilidade de aplicação da pena de perda do poder familiar em decorrência de condutas alienadoras. Muito embora tal penalidade não tenha sido expressamente reconhecida pela lei 12.318/2010, parece que o próprio sistema prevê tal possibilidade.

De acordo com o art. 1.638, IV, do Código Civil, o pai ou a mãe que incidir, reiteradamente, nas faltas previstas no art. 1.637 (dentre as quais está o abuso de autoridade parental, com a falta aos deveres a ela inerentes), perderá por ato judicial o poder familiar. E, conforme já se destacou, o art. 3. ${ }^{\circ}$ desta Lei da Alienação Parental classifica o ato de alienação parental como forma de abuso moral contra a criança e o adolescente, bem como descumprimento dos deveres inerentes à autoridade parental. Nenhum óbice resta, portanto, à decretação da perda do poder familiar (por meio, é claro, de procedimento judicial próprio, em que se garanta o contraditório) contra o genitor que pratica, reiteradamente, atos de alienação parental.

Parágrafo único. Caracterizado mudança abusiva de endereço, inviabilização ou obstrução à convivência familiar, o juiz também poderá inverter a obrigação de levar para ou retirar a criança ou adolescente da residência do genitor, por ocasião das alternâncias dos períodos de convivência familiar. 
Complementando a regra contida no inciso VI, este parágrafo único do art. $6 .^{\circ}$ visa coibir os abusos praticados pelo genitor com relação ao aspecto físico do domicílio do menor. Se naquela norma prevê-se a determinação judicial do domicílio do menor (que é critério para determinar-se a competência para o julgamento da lide referente à disputa pela guarda), aqui o legislador preocupou-se com os entraves e obstáculos físicos ao exercício do direito à convivência familiar.

Portanto, caso o guardião promova alterações de endereço de forma abusiva, com o claro intuito de obstaculizar a convivência entre o genitor alienado e os filhos, o julgador poderá determinar a inversão da obrigação de levar ou retirar os menores da residência do genitor, impondo ao guardião que o faça. A inovação é, de fato, salutar, e tende a se provar de grande eficiência na prevenção dessa forma específica de praticar a alienação parental: com a obstrução física do contato entre o genitor alienado e os filhos. Atribuindo-se-lhe a responsabilidade pelo deslocamento dos menores até a residência do genitor descontínuo, o guardião alienador tenderá a ponderar com mais cautela antes de lançar mão dessa espécie de manobra, uma vez que, se descumprir as determinações judiciais referentes ao convívio familiar dos menores com o genitor-alvo, poderá ser sancionado inclusive com a perda da guarda.

\begin{abstract}
Art. 7. ${ }^{\circ}$ A atribuição ou alteração da guarda dar-se-á por preferência ao genitor que viabiliza a efetiva convivência da criança ou adolescente com o outro genitor nas hipóteses em que seja inviável a guarda compartilhada.
\end{abstract}

Conforme já foi tratado no capítulo referente à guarda (Capítulo 2 da Parte I), a preferência do legislador foi pelo seu compartilhamento (art. 1.584, § 2. ${ }^{\circ}$, do CC/2002). Contudo, o próprio dispositivo faz a ressalva de que nem sempre a aplicação da guarda compartilhada será possível, mormente nos casos em que inexiste qualquer possibilidade da manutenção de relações minimamente cordiais entre os genitores. O compartilhamento da guarda, nesses casos, não apenas ficaria inviável, mas também prejudicaria os próprios filhos.

Não sendo possível a aplicação da guarda compartilhada, a modalidade unilateral é que será adotada, atribuindo-a, nos dizeres do art. $1.583, \S 2 .^{\circ}$, do CC/2002, ao genitor que revelar "melhores condições para exercê-la, e, objetivamente, mais aptidão para propiciar aos filhos" afeto nas relações consigo e com o seu grupo familiar, saúde e segurança e, ainda, a necessária educação. O art. 7. $^{\circ}$ da Lei 12.318/2010 veio ampliar o rol de 
características que devem ser levadas em consideração quando da atribuição da guarda unilateral, acrescentando-lhe que se prefere, em detrimento do outro, o genitor "que viabiliza a efetiva convivência da criança ou adolescente com o outro". Importante que se atente para a qualidade da viabilização da convivência do filho com o outro genitor: ela deve ser efetiva, não meramente formal, disponível. O próprio art. 1.584, caput, II, do CC/2002, especifica que o juiz deve, ao atribuir a guarda dos filhos menores, fazê-lo levando em consideração as suas necessidades específicas, ou ainda em razão da distribuição de tempo necessário ao seu convívio com o pai e com a mãe.

Assim, nota-se, mais uma vez, a extrema importância dada pelo legislador à efetivação do direito das crianças e dos adolescentes à convivência familiar. Seja na atribuição, seja na alteração da guarda, a preferência é dada, a princípio, ao genitor que mais condições reúne de viabilizar efetivamente tal direito aos seus filhos. Contudo é necessário que se tenha muita cautela, mormente nos casos em que a alienação parental já atingiu seu objetivo de dragar o menor para sua correspectiva síndrome ${ }^{266}$. Nesses casos, via de regra, e conforme se mencionou anteriormente, inverter a guarda do menor, atribuindo-a ao genitor alienado, possivelmente agravará ainda mais o dano já causado pelo genitor alienador à relação afetiva entre as duas vítimas da alienação parental. A solução seria declarar a suspensão da autoridade parental do genitor alienador (art. $6^{\circ}$, VII), atribuindo a guarda temporariamente a terceiro ${ }^{267}$ - de preferência a quem detenha

\footnotetext{
${ }^{266}$ Nesse sentido, conferir o seguinte acórdão: “Ação de regulamentação de visitas - Princípio do melhor interesse da criança - Aversão do menor à figura do pai - Indícios de alienação parental - Necessidade de convivência com a figura paterna - Assegurado o direito de visitas, inicialmente acompanhadas por psicólogos - Reforma parcial da sentença. O direito de vistas decorre do poder familiar, sendo a sua determinação essencial para assegurar o desenvolvimento psicológico, físico e emocional do filho. É certo que ao estabelecer o modo e a forma como ocorrerá as visitas, deve-se levar em conta o princípio constitucional do Melhor Interesse da Criança, que decorre do princípio da dignidade humana, centro do nosso ordenamento jurídico atual. Nos casos de alienação parental, não há como se impor ao menor o afeto e amor pelo pai, mas é necessário o estabelecimento da convivência, mesmo que de forma esporádica, para que a distância entre ambos diminua e atenue a aversão à figura paterna de forma gradativa. Não é ideal que as visitas feitas pelo pai sejam monitoradas por uma psicóloga, contudo, nos casos de alienação parental que o filho demonstra um medo incontrolável do pai, torna-se prudente, pelo menos no começo, esse acompanhamento. Assim que se verificar que o menor consegue ficar sozinho com o pai, impõem-se a suspensão do acompanhamento do psicólogo, para que a visitação passe a ser um ato natural e prazeroso" (sem grifo no original) (TJMG. ApCiv 1.0701.06.170524-3/001. 6. Câm. Cív., rel. Des. Sandra Fonseca. J. 23.03.2010. v.u.).

${ }^{267}$ Nesse sentido, conferir o seguinte acórdão: "Busca e apreensão de menor - Descumprimento de ordem Suspensão da ordem até realização de tratamento e estudo psicólogo - Agravo - Reforma parcial da decisão Agravados que adotam conduta que configura alienação parental - Procedência parcial do recurso Colocação da menor em lar substituto para afastar a alienação parental e determinação de realização de novos estudos e tratamento psicológicos necessários à solução do litígio. (...) Considerando toda a documentação juntada ao presente instrumento, conclui-se pela necessidade de retirada da menor R. dos cuidados dos agravados, colocando-a imediata e provisoriamente em lar substituto para que se possibilite a realização de novos estudos e tratamento, visando melhor análise dos perfis psicológicos da agravante e da menor R., longe da influência negativa dos agravados que insistem em manter
} 
laços de afetividade com a criança, como tios, padrinhos, ou mesmo avós -, determinandose o acompanhamento e o tratamento psicológico e/ou biopsicossocial do menor (art. 6. ${ }^{\circ}$, IV), para que o restabelecimento do seu vínculo afetivo com o genitor alienado possa se dar de maneira gradual e saudável.

Art. 8. ${ }^{\circ}$ A alteração de domicílio da criança ou adolescente é irrelevante para a determinação da competência relacionada às ações fundadas em direito de convivência familiar, salvo se decorrente de consenso entre os genitores ou de decisão judicial.

De acordo com o art. 148, parágrafo único, $b$, da Lei 8.069/1990 (ECA), a Justiça da Infância e da Juventude é competente para o fim de conhecer de ações de destituição do poder familiar, perda ou modificação de tutela ou guarda, nas hipóteses do art. 98 do estatuto, que incluem a situação de "falta, omissão ou abuso dos pais ou responsável”.

Segundo ROBERTO JOÃO ELIAS, “é relevante anotar que, normalmente, as questões referidas seriam tratadas em varas de família, mas, devido à situação do menor, que alguns, hoje, denominam 'de risco', a competência passa a ser da Justiça da Infância e da Juventude",268.

Contudo, muito embora a situação do menor vítima de alienação parental seja claramente reconhecível como "de abuso" por parte do alienador, não parece que o espírito da Lei tenha sido o de deslocar a competência das varas de família para as da infância e juventude. De acordo com a súmula 383 do STJ, "a competência para processar e julgar ações conexas de interesse de menor é, em princípio, do foro do domicílio do detentor de sua guarda".

Parece, no entanto, que a intenção do legislador foi apenas a de esclarecer que a alteração de domicílio do menor - que muitas vezes é justamente uma das formas de se perpetrar a alienação parental - não deve ser levada em consideração para fins de estabelecimento de competência relacionada às ações fundadas em direito de convivência familiar.

Se se tratar de ação incidental, por óbvio, a competência será do próprio juízo em que tramita a separação ou a ação referente à guarda ou ao regime de visitas. Contudo, tratando-se de ação autônoma, a competência deverá ser a do último domicílio do menor

comportamento de alienação parental" (sem grifo no original) (TJMG. AgIn 1.0194.11.006202-4/001. 2. ${ }^{\mathrm{a}}$ Câm. Cív., rel. Des. Brandão Teixeira. J. 04.10.2011. v.u.).

${ }^{268}$ ELIAS, Roberto João. Comentários ao Estatuto da Criança e do Adolescente: (Lei n. 8.069, de 13 de julho de 1990). 3. ed. São Paulo: Saraiva, 2008, p. 172. 
(no caso, do seu representante legal), antes da alteração - que, muitas vezes, conforme se sublinhou, deriva justamente de um ato de alienação parental.

\section{Art. 9. ${ }^{\circ}(\mathrm{VETADO})$}

A redação do dispositivo vetado era a seguinte:

Art. 9. ${ }^{\circ}$ As partes, por iniciativa própria ou sugestão do juiz, do Ministério Público ou do Conselho Tutelar, poderão utilizar-se do procedimento da mediação para a solução do litígio, antes ou no curso do processo judicial.

$\S$ 1. $^{\circ} \mathrm{O}$ acordo que estabelecer a mediação indicará o prazo de eventual suspensão do processo e o correspondente regime provisório para regular as questões controvertidas, o qual não vinculará eventual decisão judicial superveniente.

§ 2. ${ }^{\circ} \mathrm{O}$ mediador será livremente escolhido pelas partes, mas o juízo competente, o Ministério Público e o Conselho Tutelar formarão cadastros de mediadores habilitados a examinar questões relacionadas à alienação parental.

§ 3. ${ }^{\circ}$ O termo que ajustar o procedimento de mediação ou o que dele resultar deverá ser submetido ao exame do Ministério Público e à homologação judicial.

De acordo com a mensagem 513, a Presidência da República, ouvido o Ministério da Justiça, apresentou as seguintes razões de veto:

O direito da criança e do adolescente à convivência familiar é indisponível, nos termos do art. 227 da Constituição Federal, não cabendo sua apreciação por mecanismos extrajudiciais de solução de conflitos.

Ademais, o dispositivo contraria a Lei no 8.069, de 13 de julho de 1990, que prevê a aplicação do princípio da intervenção mínima, segundo o qual eventual medida para a proteção da criança e do adolescente deve ser exercida exclusivamente pelas autoridades e instituições cuja ação seja indispensável.

$\mathrm{O}$ veto ao presente dispositivo foi, de fato, pertinente e salutar. Conforme expôs a mensagem, o direito da criança e do adolescente ao convívio familiar é indisponível, sendo inviável que a decisão acerca da sua efetivação fique a cargo de mecanismos extrajudiciais de resolução de conflitos.

A mediação em conflitos familiares é medida benéfica, sem qualquer dúvida. $\mathrm{O}$ próprio ambiente judicial, envolvendo o julgador, o Ministério Público, oficiais de justiça, 
e muitas vezes até mesmo força policial (em casos, por exemplo, de busca e apreensão de menores) é, por si só, estressante e potencializador da própria situação conflituosa.

Procedimentos de mediação familiar, envolvendo profissionais com experiência em ajudar a solucionar as disputas decorrentes de perturbações no seio da família, devem ser utilizados, porém de forma complementar, e não alternativa à atuação do Estado-juiz.

\section{Art. 10. (VETADO)}

A redação do dispositivo vetado era a seguinte:

Art. 10. O art. 236 da Seção II do Capítulo I do Título VII da Lei no 8.069, de 13 de julho de 1990 - Estatuto da Criança e do Adolescente, passa a vigorar acrescido do seguinte parágrafo único:

'Art. 236.

Parágrafo único. Incorre na mesma pena quem apresenta relato falso ao agente indicado no caput ou à autoridade policial cujo teor possa ensejar restrição à convivência de criança ou adolescente com genitor.' (NR)

De acordo com a mensagem 513, a Presidência da República, ouvido o Ministério da Justiça, apresentou as seguintes razões de veto:

O Estatuto da Criança e do Adolescente já contempla mecanismos de punição suficientes para inibir os efeitos da alienação parental, como a inversão da guarda, multa e até mesmo a suspensão da autoridade parental. Assim, não se mostra necessária a inclusão de sanção de natureza penal, cujos efeitos poderão ser prejudiciais à criança ou ao adolescente, detentores dos direitos que se pretende assegurar com o projeto.

No caso do veto ao presente artigo, muito embora se concorde que a rejeição tenha sido necessária, o motivo apresentado não andou bem.

A criminalização proposta, inserindo-se um parágrafo único no art. 236 da Lei 8.069/1990 (ECA), foi redigida de maneira genérica demais, o que acabaria por inviabilizar sua aplicação na prática. O que viria a ser um "relato falso cujo teor possa ensejar restrição à convivência da criança ou adolescente com o genitor"? Seria possível, dessa maneira, a título exemplificativo, a detenção do guardião que afirmasse ao menor que o genitor descontínuo "não compareceu à sua apresentação de teatro na escola porque não gosta de você", quando, na verdade, o genitor-alvo o fez justamente para evitar acirrar 
ainda mais o conflito e, assim, agravar a situação de alienação já instaurada. A redação do dispositivo, portanto, foi falha e não se prestaria ao efetivo combate da alienação parental.

Contudo, não se pode admitir que "não se mostra necessária a inclusão de sanção de natureza penal, cujos efeitos poderão ser prejudiciais à criança ou ao adolescente”.

Inicialmente, cumpre observar que a possibilidade de prisão por desobediência (art. 330 do $\mathrm{CP}$ ), aplicável àquele que desobedecer a ordem legal de funcionário público, cuja pena de detenção varia de 15 dias a 2 meses, apesar de perfeitamente aplicável à hipótese em que o alienador descumpre ordem judicial, se mostra por demais inócua, não sendo útil à proteção do direito que se pretende garantir.

Ora, a função da norma penal restritiva de liberdade não é apenas retributiva, e, no caso de ser aplicada ao agente que pratica atos de alienação parental, teria caráter nitidamente preventivo, dissuasório, no sentido mesmo de intimidar os possíveis agentes e, dessa forma, obstar a sua prática.

Para tanto, sugere-se o seguinte Projeto de Lei:

\section{PROJETO DE LEI N. ${ }^{\circ}$}

Altera o Decreto-Lei no 2.848 , de 7 de dezembro de 1940 - Código Penal -, para tipificar como crime contra a organização da família a conduta de obstruir a convivência familiar entre os filhos menores e o genitor que não detenha a sua guarda.

\section{O CONGRESSO NACIONAL decreta:}

Art. 1. ${ }^{\circ}$ O Capítulo IV do Título VII da Parte Especial do Dec.-lei 2.848/1940 - Código Penal - passa a vigorar acrescido do seguinte artigo 249-A:

"Art. 249-A. Obstruir o contato de pessoa menor de 18 (dezoito) anos com o genitor que, não exercendo a sua guarda, tenha tido judicialmente reconhecido o direito de com ele manter a convivência familiar:

Pena - detenção, de 1 (um) mês a 1 (um) ano, e multa.

$\S 1 .^{\circ}$ Se o agente é genitor do menor:

Pena - detenção, de 3 (três) meses a 3 (três) anos, e multa.

$\S 2 .^{\circ}$ As penas aplicam-se em dobro se a criança é menor de 12 (doze) anos."

Art. 2. Esta Lei entra em vigor na data de sua publicação." 
A justificativa para a inclusão do referido dispositivo lastreia-se no fato de que, vale lembrar, a guarda, embora seja, para o direito à convivência familiar, o mais importante aspecto do poder familiar (ou autoridade parental), com ele não se confunde. $\mathrm{O}$ direito de visitas é o contraponto natural do direito de guarda, pois se presta justamente a garantir aos filhos menores, bem como ao genitor não-guardião, o equivalente direito à convivência familiar, do qual o genitor guardião já desfruta justamente por deter a guarda de tais filhos.

Conforme determinou expressamente a Lei da Alienação Parental, em seu art. 3. ${ }^{\circ}$ (e conforme já indicava, muito antes, o bom senso), a convivência familiar é direito fundamental da criança $e$ do adolescente, direito esse que é indisfarçavelmente violado quando da prática da alienação parental, que visa, por sua natureza, à obstrução da efetivação de tal direito fundamental.

A necessidade de se desestimular todo aquele que vise à obstrução do convívio entre um filho e seu genitor é justificativa mais que suficiente para a tipificação penal das condutas alienadoras. Ora, se a mera subtração física de menor de 18 (dezoito) anos do poder de quem o tenha sob sua guarda em virtude de lei ou de decisão judicial já é conduta reprovável o suficiente para configurar ilícito penal, como negar igual (ou maior) reprovabilidade à conduta daquele que, utilizando-se da sua posição de guardião do menor, influencia-o para que passe a rejeitar o seu próprio genitor, e, dessa forma, cause a si mesmo, involuntariamente, grave violação ao seu direito à convivência familiar?

Trata-se, portanto, de questão de isonomia: o art. 249 do Código Penal tipifica como crime punível com detenção de 2 meses a 2 anos a conduta do agente que subtrair menor de 18 (dezoito) anos ao poder de quem o tenha sob sua guarda em virtude de lei ou de ordem judicial, consignando no seu $\S 1 .^{\circ}$ que o fato de ser o agente pai do menor não o exime de pena, se destituído ou temporariamente privado do poder familiar ou guarda. É de se notar que o crime em questão não persegue a violação a um direito fundamental da criança ou do adolescente, mas sim ao exercício da autoridade parental do genitor guardião. Assim, se o genitor descontínuo subtrai o filho menor, deixando, por exemplo, de entregá-lo ao guardião quando findo o regulamentado período de visitas, estará cometendo o crime previsto no art. 249 do CP. E qual a justificativa para a criminalização dessa conduta, já que, apesar de não guardião, também é genitor daquele menor? Responde-se: A violação injustificada do especial espectro de poder familiar confiado ao guardião: a guarda do menor.

O $\S 2 .^{\circ}$ do mesmo art. 249 faculta ao juiz que deixe de aplicar a pena se o menor foi restituído sem que tenha sofrido qualquer tipo de maus-tratos ou privações. Mais uma vez percebe-se a lógica do tipo penal: tanto a preocupação não é com o direito à convivência familiar do menor que o legislador considerou que, se durante o período da subtração não sofrer o menor qualquer tipo de violência, a aplicação da pena mostra-se medida excessiva. A conduta, portanto, que o art. 249 do CP visa coibir é a separação 
física do menor daquela pessoa que possui o direito de tê-lo sob sua guarda e em sua companhia. E que conduta parece mais grave? Aquela que separa fisicamente o menor do seu genitor, e que pode ser remediada a qualquer instante, ou aquela que separa emocionalmente o menor do seu genitor, e que possui a potencialidade de aniquilar definitivamente os vínculos afetivos entre os dois?

Parece, portanto, justificada a necessidade de se criminalizar a conduta daqueles que praticam atos de alienação parental objetivando obstruir o convívio dos filhos menores com o genitor que não detém a sua guarda. A pena deve, naturalmente, ser mais elevada, por ser não apenas o bem jurídico tutelado - qual seja, o direito da criança e do adolescente à convivência familiar com seu genitor, e vice-versa - de maior relevância, mas também pelo resultado da prática ser mais gravoso. Além disso, a aplicação da pena em dobro nos casos em que o menor possui menos de 12 anos porque, conforme reconhecido pelos especialistas estudiosos da síndrome da alienação parental, as crianças mais novas tendem a ser mais facilmente afetadas pelas práticas alienadoras, uma vez que sua percepção da realidade e a sua capacidade de compreensão dos fatos ainda não estão bem desenvolvidas.

\subsection{Combate à obstrução do direito de convivência familiar em legislações estrangeiras}

\subsubsection{Argentina}

Demonstrando aplaudícel pioneirismo no combate à obstrução do direito à convivência familiar, a Argentina, em 3 de novembro de 1993, sancionou a Lei 24.270, criminalizando a conduta do genitor ou terceiro que impedir ou obstruir o contato de menores com o genitor não-guardião. Dos dois primeiros artigos da referida norma pode-se entrever a seriedade com que o legislador argentino tratou o descumprimento do direito à convivência familiar:

ARTICULO $1 .^{\circ}$ - Será reprimido con prisión de un mes a un año el padre o tercero que, ilegalmente, impidiere u obstruyere el contacto de menores de edad con sus padres no convivientes. Si se tratare de un menor de diez años o de un discapacitado, la pena será de seis meses a tres años de prisión.

ARTICULO 2..$^{\circ}$ En las mismas penas incurrirá el padre o tercero que para impedir el contacto del menor con el padre no conviviente, lo mudare de domicilio sin autorización judicial.

Si con la misma finalidad lo mudare al extranjero, sin autorización judicial o excediendo los límites de esta autorización, las penas de 
prisión se elevarán al doble del mínimo y a la mitad del máximo (sem grifo no original) $^{269}$.

Pune-se, portanto, com prisão, a obstrução do convívio dos filhos menores com o genitor descontínuo. Não se trata propriamente de uma lei acerca da alienação parental: nada se fala sobre os atos de alienação parental que, a exemplo da norma brasileira, permitem ampla atuação judicial no sentido de prevenir a obstrução do convívio familiar dos filhos menores com o genitor não-guardião, decorrente, por exemplo, da síndrome da alienação parental. O objetivo último, contudo, é o mesmo: preservar a convivencia familiar e os laços de afetividade entre os filhos e o genitor descontínuo.

\title{
8.7.2. Espanha
}

Na Espanha, o art. 225 bis do Código Penal estabelece punição à subtração de menores. E, muito embora a criminalização de tal conduta, via de regra, refira-se à separação dos filhos menores do seu genitor guardião, na lei espanhola pode-se verificar que existe espaço para punição ao agente que subtrai o menor também do genitor nãoguardião. Veja-se:

\begin{abstract}
Artículo 225 bis.
1. El progenitor que sin causa justificada para ello sustrajere a su hijo menor será castigado con la pena de prisión de dos a cuatro años e inhabilitación especial para el ejercicio del derecho de patria potestad por tiempo de cuatro a diez años.
\end{abstract}

\section{A los efectos de este artículo, se considera sustracción:}

1. ${ }^{\circ}$ El traslado de un menor de su lugar de residencia sin consentimiento del progenitor con quien conviva habitualmente o de las personas o instituciones a las cuales estuviese confiada su guarda o custodia.

$2 .^{\circ}$ La retención de un menor incumpliendo gravemente el deber establecido por resolución judicial o administrativa.

$(\ldots)$

5. Las penas señaladas en este artículo se impondrán igualmente a los ascendientes del menor y a los parientes del progenitor hasta el segundo grado de consanguinidad o afinidad que incurran en las conductas anteriormente descritas ${ }^{270}$ (sem grifo no original).

O parágrafo 2..$^{\circ}$ do item 2 considera que a subtração mencionada no item 1 também ocorre quando existe a retenção de um menor em grave descumprimento de dever

\footnotetext{
269 Disponível em: <http://www.infoleg.gov.ar/infolegInternet/anexos/0-4999/668/norma.htm>. Acesso em 18 de abril de 2011 .

270 Disponível em: <http://www.boe.es/aeboe/consultas/bases datos/act.php?id=BOE-A-199525444\&p=20110129\&tn=1\#a225bis $>$. Acesso em 02 de maio de 2011.
} 
estabelecido por decisão judicial ou administrativa. Portanto, parece acertado considerar que a conduta do genitor guardião que descumpre o regime de convivência dos filhos com o genitor descontínuo, determinado no processo de divórcio, amolda-se ao tipo penal.

Também no caso espanhol, contudo, percebe-se que a norma penal não se refere à alienação parental, mas sim à objetiva obstrução do direito à convivência familiar.

\subsubsection{Estado da Califórnia, EUA}

A Califórnia, em seu Código Penal estadual, também criminaliza a conduta de obstruir o direito à visita, cominando pena de prisão e/ou multa à conduta tipificada. Não menciona expressamente a palavra genitor ao se referir à autoria da obstrução ao direito de visitas, mas ao utilizar a expressão "toda pessoa" acabou incluindo, também, o genitor guardião.

\section{5.}

(a) Every person who takes, entices away, keeps, withholds, or conceals a child and maliciously deprives a lawful custodian of a right to custody, or a person of a right to visitation, shall be punished by imprisonment in a county jail not exceeding one year, a fine not exceeding one thousand dollars $(\$ 1,000)$, or both that fine and imprisonment, or by imprisonment pursuant to subdivision (h) of Section 1170 for 16 months, or two or three years, a fine not exceeding ten thousand dollars $(\$ 10,000)$, or both that fine and imprisonment.

(b) Nothing contained in this section limits the court's contempt power.

(c) A custody order obtained after the taking, enticing away, keeping, withholding, or concealing of a child does not constitute a defense to a crime charged under this section (sem grifo no original) ${ }^{271}$.

\subsubsection{França}

O Código Penal francês, por seu turno, prevê punição consistente em prisão e multa ao ato de indevidamente recusar-se a entregar um menor a quem possua o direito de reclamá-lo. Assim, havendo regime de visitas estabelecido em decisão judicial, pode ser punido o genitor guardião que se recusa a entregar o filho ao outro genitor, para o exercício do direito de convivência familiar.

Article 227-5 - Le fait de refuser indûment de représenter un enfant mineur à la personne qui a le droit de le réclamer est puni d'un an d'emprisonnement et de 15000 euros d'amende.

${ }^{271}$ Disponível em: 〈http://www.leginfo.ca.gov/>. Acesso em 05 de maio de 2011. 
Estabelece, ainda, no artigo seguinte, penalidades de prisão e multa a quem, detendo a guarda de filhos menores, altera o local de residência sem comunicar, em um mês a partir da mudança, o fato a quem esteja garantido, por decisão judicial ou acordo homologado judicialmente, o direito de visitar os menores:

Article 227-6 - Le fait, pour une personne qui transfère son domicile en un autre lieu, alors que ses enfants résident habituellement chez elle, de ne pas notifier son changement de domicile, dans un délai d'un mois à compter de ce changement, à ceux qui peuvent exercer à l'égard des enfants un droit de visite ou d'hébergement en vertu d'un jugement ou d'une convention judiciairement homologuée, est puni de six mois d'emprisonnement et de $\mathbf{7 5 0 0}$ euros d'amende (sem grifo no original) $^{272}$.

Mais uma vez vê-se que a punição estatal direciona-se ao descumprimento do direito à convivência familiar, sem que se trate especificamente das hipóteses de alienação parental. Trata-se, assim, como nos exemplos dos demais países mencionados, de punição a uma forma objetiva, física, de obstrução ao direito de visitas, muito mais relacionado à ideia de subtração de menores do que de uma forma de alienação parental.

Há, no entanto, tramitando na Assembleia Nacional Francesa, dois projetos de lei que, visando proteger as crianças e adolescentes e o seu direito à convivência familiar sadia, mencionam expressamente a síndrome da alienação parental em suas exposições de motivos.

Assim como a proposition de loi 1710, de 3 de junho de 2009, o projeto legislativo 3834, de 18 de outubro de 2011, busca preservar a autoridade parental compartilhada e privilegiar a residência alternada do menor em caso de separação dos seus pais. Seguem transcritas, adiante, as principais alterações propostas pelo segundo projeto, que englobou e ampliou as proposições contidas no primeiro:

Article 1er: Le dernier alinéa de l'article 373-2 du code civil est remplacé par six alinéas ainsi rédigés :

\section{(...)}

«Tout enfant a le droit d'entretenir des relations personnelles avec ses deux parents. Dès lors que l'autorité parentale est conjointe, le juge aux affaires familiales a pour devoir de maintenir et si besoin de rétablir ce lien parental.

${ }^{272}$ Disponível em: 〈http://www.legifrance.gouv.fr/initRechCodeArticle.do >. Acesso em: 20 de maio de 2011. 
"Lorsqu'un parent est exclu par l'autre parent de tout choix, de toute orientation, de toute décision concernant le présent et l'avenir de l'enfant, ou lorsqu'il est victime de toute entrave à l'exercice de son autorité parentale telle que définie à l'article 371-1, il peut saisir le juge aux affaires familiales afin de faire respecter ses droits.

"Au vu des entraves constatées dans les relations familiales, dans le domaine éducatif, ou dans tous les domaines se rapportant à la santé ou la sécurité de l'enfant, le juge prend toutes les mesures de nature à faire cesser l'entrave à l'autorité parentale. Dans ce cadre, il rappelle les devoirs et les droits mutuels de chaque parent $»(\text { sem grifo no original })^{273}$.

As alterações pretendidas no art. 373-2 (foram transcritas apenas as referentes ao exercício do direito de visitas) tratam, assim, de estabelecer o dever do juiz de fazer cessarem os entraves ao estabelecimento ou à manutenção da convivência familiar.

A criminalização da conduta do ascendente que obstrui o exercício da autoridade parental através de condutas reiteradas e manipulações diversas, objetivando romper os laços familiares entre os filhos e um genitor vem proposta no art. 2. ${ }^{\circ}$ do projeto de lei, visando a alteração do art. 227-2 do Código Penal:

Article 2: L'article L. 227-2 du code pénal est complété par un alinéa ainsi rédigé :

"Le fait, par tout ascendant, d'entraver l'exercice de l'autorité parentale par des agissements répétés ou des manipulations diverses ayant pour objet la dégradation voire la rupture du lien familial, est puni d'un an emprisonnement et de 15000 euros d'amende. »

Nota-se, aqui, muito embora não se utilize a expressão alienação parental, que foram levados em consideração, ainda que de forma tímida, alguns elementos possivelmente caracterizadores da alienação parental. Busca-se, assim, garantir, através de normas civis e penais, o combate à obstrução da autoridade parental nos casos em que se verifica a alienação parental.

\subsubsection{Bélgica}

Na Bélgica, através da proposition de loi 5-520/1, de 23 de novembro de 2010, prevê-se a alteração tanto do Código Civil como do Código Penal, com o intuito de preservar o direito à convivência familiar dos filhos menores cujos pais são separados.

\footnotetext{
${ }^{273}$ Disponível em: 〈http://www.assemblee-nationale.fr/13/propositions/pion3834.asp〉. Acesso em: 20 de maio de 2011.
} 
Também neste projeto de lei, em sua exposição de motivos, é mencionada a síndrome da alienação parental e, mais especificamente, é citado o trabalho de Richard Gardner, mencionando-se inclusive as características manifestações da SAP nas crianças e, também, o risco da demora na identificação e no combate aos atos de alienação parental.

A principal e mais contundente proposta é a inclusão, no Código Penal, de um tipo que criminaliza a ação do genitor alienador.

Art. 6. Dans le chapitre III de la partie VIII du Code pénal, une section Vbis, comprenant um article 432bis, est insérée, rédigée comme suit:

«Section Vbis. De l'aliénation parentale.

Art. 432bis. - Sans préjudice de l'application des articles 1385bis et suivants du Code judiciaire relatifs à l'astreinte, tout parent qui entrave sciemment l'exercice de l'autorité parentale par des agissements répétés ou des manipulations diverses ayant pour objet la dégradation voire la rupture du lien affectif familial envers l'autre parent sera puni d'un emprisonnement de huit jours à un an et d'une amende de vingt-six euros à mille euros ou d'une de ces peines seulement » (sem grifo no original $)^{274}$.

Pretende a legislação projetada, assim, punir o entrave ao exercício do convívio familiar, realizado através de atos de alienação parental, com multa e prisão do genitor alienador.

Percebe-se, assim, que também nos demais países a preocupação com o desrespeito ao direito à convivência familiar, tanto das crianças e adolescentes como do genitor não guardião, vem se ampliando - inclusive através da legislação projetada, que busca até mesmo criminalizar os atos que importem em alienação parental. 


\section{CONCLUSÃO}

Eu tive uma mãe muito maravilhosa, de eu bebezinha até minha adolescência toda. Minha mãe era tudo para mim. Eu lembro do quanto ela era carinhosa, do quanto era cuidadosa, de tudo isso. Eu tive uma mãe realmente maravilhosa. Mas eu lembro também que essa mãe maravilhosa falava muito mal do meu pai. Então eu cresci com esse ódio do meu pai. Quando eu comecei a ter consciência, eu vejo que ela atrapalhou muito nessa relação com meu pai. Se ela tivesse percebido que o meu pai não deu certo com ela como homem, e que isso não interferiria nele como pai, podia ter sido tão mais saudável, a vida toda. Não precisaria ter esse buraco que eu tenho, de não ter essa presença, e agora eu não estar falando nem com ela, nem com meu irmão, que eu sinto muita falta.

(...)

A coisa que eu mais tenho medo na vida é ter um filho e um dia, se eu vier a me separar, fazer a mesma coisa, usar meu filho contra o marido. É o meu maior pânico na vida. A coisa que eu mais me preocupo hoje é, se um dia eu não dar certo com quem eu estou, não usar meu filho contra isso, não usar ele como fantoche. É o que eu tenho mais medo.

Sófocles poderia muito bem, em uma de suas peças, ter sido o primeiro a retratar a alienação parental e os seus efeitos. O trecho apresentado é parte do relato da tragédia vivida pela publicitária carioca R. L., quando adolescente, e mesmo durante o início da vida adulta, período em que foi vítima da alienação parental provocada por sua mãe, após seu pai ter desta se separado e constituído outra família. Seu relacionamento com o pai sofreu um hiato de inexistência que durou $11 \operatorname{anos}^{275}$.

Este episódio é apenas um dos inúmeros exemplos encontrados no decorrer das pesquisas que deram origem a esta dissertação. A doutrina específica - especialmente na área da psicologia e psiquiatria infantil - é rica em casos similares, cada um mais preocupantemente desolador que o outro.

Quando primeiro tive contato com essa temática, não possuía a real dimensão da sua gravidade. Já havia acompanhado algumas disputas judiciais envolvendo separação, divórcio, e mesmo a guarda de filhos e o direito de visitas. A presente pesquisa, contudo, serviu para que eu compreendesse a enormidade da tragédia humana que pode decorrer da alienação parental.

A alienação parental, bem como a instalação da sua síndrome, derivam única e exclusivamente da incapacidade que um adulto possui de lidar de maneira madura e

\footnotetext{
${ }^{275}$ Transcrição de trecho do documentário "A MORTE INVENTADA”. Roteiro e Direção: ALAN MINAS.
} Produção: Daniela Vitorino. Brasil. Caraminhola Produções, 2009. 01 DVD (78 min), NTSC, color. 
centrada com os problemas que levaram ao fim do seu relacionamento com o outro genitor dos seus filhos. Não se trata de uma crítica leviana e desprovida de análise mais abrangente de todas as vicissitudes que podem envolver cada caso, especificamente. A intensidade do conflito, assim como a capacidade das partes de com ele lidarem sem envolver exageradamente os frutos humanos da união que se desfez, está diretamente conectada, ainda, aos motivos da separação e à forma como ela ocorreu. E quando se fala em "não envolver exageradamente os filhos" é porque, sendo parte da mesma família, do mesmo minúsculo grupo social, seria praticamente impossível que não fossem envolvidos. Aliás, muitas vezes os filhos podem inclusive fazer parte dos motivos - legítimos ou não - que ensejaram a separação.

O grande dilema quando o Judiciário se depara com um possível caso de alienação parental na disputa pela guarda de menores não é tanto identificar a sua existência; mais que isso, a grande dificuldade reside no que fazer, como agir, e quando agir. Não há preparo suficiente - por motivos que, até a edição da Lei 12.318/2010 se justificavam, mas que já não se justificam mais - por parte do Judiciário (tanto dos julgadores, quanto dos profissionais integrantes das equipes multidisciplinares), do Ministério Público e até mesmo dos advogados para que ajam com a necessária diligência em casos envolvendo a alienação parental.

Tempo, tempo, tempo. O seu transcorrer - e como transcorre às braças nas disputas judiciais! - é, sem dúvida, o principal e mais agressivo inimigo do combate à alienação parental. Não se pode enfatizar o suficiente, através de palavras, o quanto uma atuação precisa, imediata e, acima de tudo, eficaz é absolutamente necessária para que se combater, com sucesso, tal pernicioso fenômeno - sejam quais forem as suas causas, conscientes ou não. A ação alienadora é, obviamente, desprezível e merecedora de repúdio por parte tanto da moral como do direito. Contudo, o mais importante, em qualquer situação, é impedir e/ou reverter os nefastos resultados que invariavelmente se observam quando de um bem-sucedido desenvolvimento da síndrome da alienação parental. Portanto, o principal objeto de combate é a consequência, não a causa da alienação parental.

O cerne de toda a discussão, portanto, é: a alienação parental, campanha de difamação e denegrimento perpetrada contra a relação afetiva entre um genitor e seus filhos, possui a capacidade de aniquilá-la, e quanto mais tempo os filhos passarem sob a influência do alienador, mais chances de sucesso a alienação terá em destruir esses vínculos entre as crianças e o genitor alienado. 
Por esses motivos se insiste, sem qualquer dúvida, que sob todos os aspectos o combate aos atos de alienação parental, buscando impedir ou reverter a instalação da sua síndrome, é medida que se impõe, com total e absoluta prioridade, se o Judiciário de fato pretende combater esse mal sofrido por tantas famílias, e que, cada vez mais, é verificado nos processos de disputa por guarda.

A realidade incontestável é que não se pode falar em proteção integral da criança e do adolescente, nem muito menos na garantia do seu melhor interesse se o grave problema da alienação parental não for enfrentado com a necessária seriedade, sob pena, repete-se, da formação de uma legião de órfãos de pais vivos que não apenas carregarão consigo o sofrimento pela irrecuperável perda daquilo que poderiam ter tido, mas que também se tornarão alienadores em potencial, alimentando o círculo vicioso - e odioso - da destruição dos vínculos afetivos entre pais e filhos, que passarão, sim, a se divorciar. 


\section{REFERÊNCIAS BIBLIOGRÁFICAS}

AKEL, Ana Carolina Silveira. Guarda compartilhada - uma nova realidade. In: COLTRO, Antônio Carlos Mathias; DELGADO, Mário Luiz (coords.). Guarda Compartilhada. São Paulo: Editora Método, 2009, p. 41-47.

ALVES, José Carlos Moreira. Direito romano. 14. ed., 3. tir. Rio de Janeiro: Forense, 2010.

A MORTE INVENTADA. Roteiro e Direção: ALAN MINAS. Produção: Daniela Vitorino. Brasil. Caraminhola Produções, 2009. 01 DVD (78 min), NTSC, color.

ANDRITZKY, Walter. The role of medical reports in the development of parental alienation. In: GARDNER, Richard A.; LORANDOS, Demosthenes; SAUBER, S. Richard (org.) The International Handbook of Parental Alienation Syndrome. 2nd ed. Springfield, IL : Charles C Thomas Publisher LTD, 2006, p. 195-208.

ARAI, Rubens Hideo. Guarda compartilhada e ação de assunção de obrigação parental. In: NANNI, Giovanni Ettore (coord.). Temas relevantes do Direito Civil Contemporâneo - reflexões sobre os cinco anos do Código Civil - Estudos em homenagem ao Professor Renan Lotufo. São Paulo: Atlas, 2008, p. 627-664.

BARBOSA, Águida Arruda. Proteção da pessoa dos filhos: mediação familiar e interdisciplinaridade. In: CHINELLATO, Silmara Juny; SIMÃO, José Fernando; FUJITA, Jorge Shiguemitsu; ZUCCHI, Maria Cristina (orgs.). Direito de Família no Novo Milênio: estudos em homenagem ao Professor Álvaro Villaça Azevedo. São Paulo: Atlas, 2010, p. 437-445.

BARDEN, R. Christopher. Protecting the fundamental rights of children and families: parental alienation syndrome and Family Law reform. In: GARDNER, Richard A.; LORANDOS, Demosthenes; SAUBER, S. Richard (org.) The International Handbook of Parental Alienation Syndrome. 2nd ed. Springfield, IL : Charles C Thomas Publisher LTD, 2006, p. 419-432.

BASSET, Lidia N. Makianich. Derecho de visitas: régimen jurídico del derecho y deber de adecuada comunicación entre padres e hijos. 1. ed., $1^{\mathrm{a}}$ reimp. Buenos Aires: Hammurabi, 1997.

BAYER, Sandra Regina Garcia Olivan. Direito-dever de visita. Dissertação de Mestrado. Faculdade de Direito da Universidade de São Paulo, 1999.

BENETI, Sidnei Agostinho. Os direitos de guarda, visita e fiscalização dos filhos ante a separação dos pais. Revista dos Tribunais, 1987, nº 622, p. 37-45.

BERNET, William, VON BOCH-GALHAU, Wilfrid, BAKER, Amy J. L. and MORRISON, Stephen L. Parental Alienation, DSM-V, and ICD-11. The American Journal of Family Therapy, 38: 2, 76 - 187, 2010. Disponível em: 
$\langle$ https://netfiles.uiuc.edu/r-ferrer/VisitationSchedule/PAS/BernetDSM5.pdf $>$. Acesso em 20 de julho de 2011.

BERNET, William. Sexual abuse allegations in the context of child custody disputes. In: GARDNER, Richard A.; LORANDOS, Demosthenes; SAUBER, S. Richard (org.) The International Handbook of Parental Alienation Syndrome. 2nd ed. Springfield, IL : Charles C Thomas Publisher LTD, 2006, p. 242-263.

BITTAR, Carlos Alberto. Novos rumos do Direito de Família. In: BITTAR, Carlos Alberto (coord.). O Direito de Família e a Constituição de 1988. São Paulo: Saraiva, 1989, p. $1-52$.

BORDA, Guillermo. Manual de Derecho de Familia. Buenos Aires: Perrot, 1988.

BOSSERT, Gustavo A.; ZANNONI, Eduardo A. Manual de derecho de familia. 5. ed., actualizada y ampliada. Buenos Aires : Editorial Astrea, 2001.

BRANCHER, Naiara. O Estatuto da Criança e do Adolescente e o novo papel do Poder Judiciário. In: PEREIRA Tânia da Silva (coord.). O melhor interesse da criança: um debate interdisciplinar. Rio de Janeiro: Renovar, 1999, p. 137-154.

BRODY, Barry. The misdiagnosis of PAS. In: GARDNER, Richard A.; LORANDOS, Demosthenes; SAUBER, S. Richard (org.) The International Handbook of Parental Alienation Syndrome. 2nd ed. Springfield, IL : Charles C Thomas Publisher LTD, 2006, p. 209-227.

BURRILL-O'DONNELL, Janelle. Parental alienation syndrome in court referred custody cases. USA: Dissertation.com, 2002.

BURRILL, Janelle. Reluctance to verify PAS as a legitimate syndrome. In: GARDNER, Richard A.; LORANDOS, Demosthenes; SAUBER, S. Richard (org.) The International Handbook of Parental Alienation Syndrome. 2nd ed. Springfield, IL : Charles C Thomas Publisher LTD, 2006, p. 323-330.

CARBONNIER, Jean. Droit civil, t. 2, 21. ed. Paris: PUF, 2002, p. 7.

CARBONERA, Silvana Maria. Guarda de filhos na família constitucionalizada. Porto Alegre : Sergio Antonio Fabris Editor, 2000.

CASTRO, Lidia Rosalina Folgueira. Disputa de guarda e visitas: no interesse dos pais ou dos filhos?. São Paulo: Casa do Psicólogo, 2003.

CASSETARI, Christiano. Guarda compartilhada: uma análise da Lei 11.698/2008. In: COLTRO, Antônio Carlos Mathias; DELGADO, Mário Luiz (coords.). Guarda Compartilhada. São Paulo: Editora Método, 2009, p. 95-102.

CEZAR-FERREIRA, Verônica A. da Motta. Família, separação e mediação - uma visão psicojurídica. 2. ed. São Paulo: Ed. Método, 2007. 
CHARTIER, Roger (org.). História da vida privada, 3: Da Renascença ao Século das Luzes. Trad. Hildegard Feist - São Paulo: Companhia das Letras, 2009.

COLTRO, Antônio Carlos Mathias. A guarda (rectius, cuidado) com os filhos. In: COLTRO, Antônio C. M. (coord.). Estudos jurídicos em homenagem ao centenário de Edgard de Moura Bittencourt - A revisão do Direito de Família. Rio de Janeiro: GZ Editora, 2009, p. 19-46.

DARNALL, Douglas. Divorce casualties - protecting your children from parental alienation. Lanham: Taylor Trade Publishing, 1998.

DIAS, Maria Berenice. Incesto e o mito da família feliz. In: DIAS, Maria Berenice (coord.). Incesto e Alienação Parental - realidades que a Justiça insiste em não ver. São Paulo: RT, 2007, p. 17-50.

. Manual de Direito das Famílias. 8. ed. rev. atual. e ampl. São Paulo: RT, 2011.

ELIAS, Roberto João. ELIAS, Roberto João. Comentários ao Estatuto da Criança e do Adolescente: (Lei n. 8.069, de 13 de julho de 1990). 2. ed. São Paulo: Saraiva, 2004.

Comentários ao Estatuto da Criança e do Adolescente: (Lei n. 8.069, de 13 de julho de 1990). 3. ed. São Paulo: Saraiva, 2008.

Curso elementar de Direito de Família. São Paulo: 2005.

. Direitos fundamentais da criança e do adolescente. São Paulo: Saraiva, 2005.

Pátrio poder: guarda dos filhos e direito de visita. São Paulo: Saraiva, 1999.

FARIAS, Cristiano Chaves de. A família da pós-modernidade: em busca da dignidade da pessoa humana. Revista de Direito Privado, São Paulo, nº 19, p. 56-68.

FERREIRA, Maria Helena Mariante. Memórias falsas ou apuração inadequada? In: DIAS, Maria Berenice (coord.). Incesto e Alienação Parental - realidades que a Justiça insiste em não ver. São Paulo: RT, 2007, p. 140-146.

FIGUEIREDO, Fábio Vieira; ALEXANDRIDIS, Georgios. Alienação parental: aspectos materiais e processuais da Lei n. 12.318, de 26-8-2010. São Paulo: Saraiva, 2011.

FONSECA, Priscila M. P. Corrêa. Síndrome da Alienação Parental. Revista Brasileira de Direito de Família. Ano VIII, no 40 - Fev-Mar 2007.

FREITAS, Douglas Philips; PELLIZZARO, Graciela. Alienação parental - comentários à Lei 12.312/2010. Rio de Janeiro: Forense, 2011.

FUJITA, Jorge Shiguemitsu. Filiação. São Paulo: Atlas, 2009.

GALUPPO, Marcelo Campos. Da ideia à defesa: monografias e teses jurídicas. 2. ed. rev. e atual. Belo Horizonte: Ed. Mandamentos, 2008. 
GAMA, Guilherme Calmon Nogueira da. Princípio da paternidade responsável. Revista de Direito Privado, São Paulo, no 18, p. 21-41, 2004.

GARDNER, Richard. Introduction. In: GARDNER, Richard A.; LORANDOS, Demosthenes; SAUBER, S. Richard (org.) The International Handbook of Parental Alienation Syndrome. 2nd ed. Springfield, IL : Charles C Thomas Publisher LTD, 2006, p. 33-48.

The boys and girls book about divorce. New York : Bantam Books, 1985.

. The Parental Alienation Syndrome. 2nd ed. Creskill, NJ : Creative Therapeutics Inc., 1998.

The Parental Alienation Syndrome and the corruptive power of anger. In: GARDNER, Richard A.; LORANDOS, Demosthenes; SAUBER, S. Richard (org.) The International Handbook of Parental Alienation Syndrome. 2nd ed. Springfield, IL : Charles C Thomas Publisher LTD, 2006, p. 33-48.

GARNICA, María del Carmen García. El síndrome de alienación parentala la luz del interés superior del menor. In: Revista Derecho Privado y Constitución núm. 73, p. 201248, enero/diciembre $2009 . \quad$ Disponível em: $<$ http://revistas.cepc.es/revistas.aspx?IDR=7\&IDN=685\&IDA=27662 >. Acesso em $29 \mathrm{de}$ setembro de 2010.

GLANZ, Semy. A família mutante - sociologia e direito comparado: inclusive o novo Código Civil. Rio de Janeiro: Renovar, 2005.

GLENDON, Mary Ann. The transformation of the family law. Chicago: The University of Chicago Press, 1989.

GOLDENBERG, Gita; GONÇALVES, Cesar. Estudo psíquico-jurídico das relações de filiação decorrentes de separações conjugais. Revista dos Tribunais, $\mathrm{n}^{\circ}$ 806, p. 35-43.

GOLDSTEIN, Joseph; SOLNIT, Albert J.; GOLDSTEIN, Sonja; FREUD, Anna. The best interests of the child. New York: The Free Press, 1996.

GRISARD FILHO, Waldyr. Guarda compartilhada: um novo modelo de responsabilidade parental. São Paulo: Ed. Revista dos Tribunais, 2000.

GROENINGA, Giselle Câmara. Do interesse à criança ao melhor interesse da criança. Boletim do IBDFAM n. ${ }^{\circ}$ 19, de 22.04.2002. Disponível em: <http://www.ibdfam.org.br/?artigos\&artigo=44>. Acesso em: 11 de outubro de 2010.

Entre o público e o privado, famílias. Boletim do IBDFAM $\mathbf{n}^{\circ} \mathbf{2 5}$, de 20.06.2004. Disponível em: $\langle$ http://www.ibdfam.org.br/?artigos\&artigo=138 $>$. Acesso em: 21 de junho de 2010 .

O fenômeno da alienação parental. In Direito de família: processo, teoria e prática. Rio de Janeiro: Forense, 2008, p. 
Guarda compartilhada - a efetividade do poder familiar. In: COLTRO, Antônio Carlos Mathias; DELGADO, Mário Luiz (coords.). Guarda Compartilhada. São Paulo: Editora Método, 2009, p. 149-170.

. Um aporte interdisciplinar ao Direito de Família. Disponível em: <http://www.ibdfam.org.br/?artigos\&artigo=12>. Acesso em: 05 de abril de 2011.

GUAZELLI, Mônica. A falsa denúncia de abuso sexual. In: DIAS, Maria Berenice (coord.). Incesto e Alienação Parental - realidades que a Justiça insiste em não ver. São Paulo: RT, 2007, p. 112-139.

HAYWARD, Stan. A guide to the parental alienation syndrome. Disponível em: <http://www.coeffic.demon.co.uk/pas.htm>, acesso em 10 de maio de 2010.

HIRONAKA, Giselda Maria Fernandes Novaes. Os contornos jurídicos da responsabilidade afetiva na relação entre pais e filhos: além da obrigação legal de caráter material. Disponível em: 〈http://www.ibdfam.org.br/?artigos\&artigo=289> Acesso em: 19 de outubro de 2010.

HOBBS, Tony. Legal requirements of experts giving evidence to courts in the United Kingdom: PAS and the experts failure to comply. In: GARDNER, Richard A.; LORANDOS, Demosthenes; SAUBER, S. Richard (org.) The International Handbook of Parental Alienation Syndrome. 2nd ed. Springfield, IL: Charles C Thomas Publisher LTD, 2006, p. 439-450.

PAS in the United Kindgom: Problem in recognition and managment. In: GARDNER, Richard A.; LORANDOS, Demosthenes; SAUBER, S. Richard (org.) The International Handbook of Parental Alienation Syndrome. 2nd ed. Springfield, IL : Charles C Thomas Publisher LTD, 2006, p. 71-89.

JEFFRIES, Michael; DAVIES, Joel. A family's heartbreak - a parent's introduction to parental alienation. Stamford: A Family's Heartbreak LLC, 2008.

LAGRASTA NETO, Caetano. Direito de Família - A família brasileira no final do século XX. São Paulo: Malheiros Ed., 2000.

Responsabilidade civil nas relações familiares. In: COLTRO, Antônio C. M. (coord.). Estudos jurídicos em homenagem ao centenário de Edgard de Moura Bittencourt - A revisão do Direito de Família. Rio de Janeiro: GZ Editora, 2009, p. 81-122.

LAURIA, Flávio Guimarães. A regulamentação de visitas e o princípio do melhor

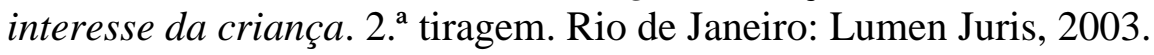

LAZZARINI, Patrícia Daher. A proteção da criança pelo exercício da guarda de menores e da visita. Dissertação de Mestrado. Faculdade de Direito da Universidade de São Paulo. São Paulo, 2009.

LEITE, Eduardo de Oliveira. Famílias monoparentais - a situação jurídica de pais e mães separados e dos filhos na ruptura da vida conjugal. 2. ed. rev. atual. e ampl. São Paulo: RT, 2001. 
LIBERATI, Wilson Donizeti. Princípio do Best interest of the child na justiça juvenil dos Estados Unidos: uma breve análise entre sistemas judiciais juvenis. In: PEREIRA Tânia da Silva (coord.). O melhor interesse da criança: um debate interdisciplinar. Rio de Janeiro: Renovar, 1999, p. 411-432.

LÔBO, Paulo Luiz Netto. A repersonalização das relações de família. In: BITTAR, Carlos Alberto (coord.). O Direito de Família e a Constituição de 1988. São Paulo: Saraiva, 1989, p. 53-82.

LORANDOS, Demosthenes. Parental Alienation Syndrome in American Law. In: GARDNER, Richard A.; LORANDOS, Demosthenes; SAUBER, S. Richard (org.) The International Handbook of Parental Alienation Syndrome. 2nd ed. Springfield, IL : Charles C Thomas Publisher LTD, 2006, p. 333-351.

LOWENSTEIN, Ludwig F. The psychological effects and treatment of the parental alienation syndrome. In: GARDNER, Richard A.; LORANDOS, Demosthenes; SAUBER, S. Richard (org.) The International Handbook of Parental Alienation Syndrome. 2nd ed. Springfield, IL : Charles C Thomas Publisher LTD, 2006, p. 292-301.

MAJOR, Jayne A. Helping clients deal with parental alienation syndrome. In: GARDNER, Richard A.; LORANDOS, Demosthenes; SAUBER, S. Richard (org.) The International Handbook of Parental Alienation Syndrome. 2nd ed. Springfield, IL : Charles C Thomas Publisher LTD, 2006, p. 276-285.

MALUF, Adriana Caldas do Rego Freitas Dabus. Novas modalidades de família na pósmodernidade. São Paulo: Ed. Atlas, 2010.

MARRACCINI, Eliane Michelini; MOTTA, Maria Antonieta Pisano. Guarda dos filhos: algumas diretrizes psicanalíticas. Revista dos Tribunais, n. ${ }^{\circ}$ 716, jun. 1995, p. 346-357.

MILAGRES, Marcelo de Oliveira. Normas cogentes e dispositivas de direito de família. Revista de Direito Privado, n. ${ }^{\circ}$ 35, jul. 2008. p. 211-228.

MÔNACO, Gustavo Ferraz de Campos. A proteção da criança no cenário internacional. Belo Horizonte: Del Rey, 2005.

O décimo-quinto aniversário da Convenção sobre os Direitos da Criança contributo para o aprofundamento e implementação do direito internacional dos direitos humanos. Revista dos Tribunais, n. ${ }^{\circ}$ 831, jan. 2005, p. 132-146.

MONTEIRO, Washington de Barros. Curso de Direito Civil, vol. 2 - Direito de Família. 39. ed. São Paulo: Saraiva, 2009.

NOVAES, Maria Helena. O "maior interesse" da criança e do adolescente face às suas necessidades biopsicossociais - uma questão psicológica. In: Tânia Pereira da Silva (coord.). O melhor interesse da criança: um debate interdisciplinar. Rio de Janeiro: Renovar, 1999, p. 525-536. 
NUNES, José Carlos Amorim de Vilhena. Novos vínculos jurídicos nas relações de família. Dissertação de Mestrado. Faculdade de Direito da Universidade de São Paulo, 2009.

PAIS, Maria Santos. Le meilleur intérêt de l'enfant. In: PEREIRA, Tânia da Silva Pereira (coord.). O Melhor Interesse da Criança: um debate Interdisciplinar. Rio de Janeiro: Renovar, 1999, p. 537-550.

PEREIRA, Caio Mário da Silva. Instituições de Direito Civil, vol. V - Direito de Família. 17. ed. rev. e atual. por Tânia da Silva Pereira. Rio de Janeiro: Forense, 2009.

PEREIRA, Rodrigo da Cunha. Pai, por que me abandonaste?. In: PEREIRA, Tânia da Silva (coord.). O melhor interesse da criança: um debate interdisciplinar. Rio de Janeiro: Renovar, 1999, p. 575-586.

; GROENINGA, Giselle Câmara. Direito de família e psicanálise - rumo a uma nova epistemologia. Rio de Janeiro: Imago, 2003.

PEREIRA, Tânia da Silva. Da adoção. In: DIAS, Maria Berenice; PEREIRA, Rodrigo da Cunha (coords.). Direito de família e no novo Código Civil. 3. ed. Belo Horizonte: Del Rey, 2003, p. 151-176.

Direito da criança e do adolescente - uma proposta interdisciplinar. 2. ed. rev. e atual. São Paulo: Renovar, 2008.

O melhor interesse da criança. In: PEREIRA, Tânia da Silva (coord.). O melhor interesse da criança: um debate interdisciplinar. Rio de Janeiro: Renovar, 1999, p. 1-101.

PEREIRA, Tânia da Silva; FRANCO, Natália Soares. O direito fundamental à convivência familiar e a guarda compartilhada. In: COLTRO, Antônio Carlos Mathias; DELGADO, Mário Luiz (coords.). Guarda Compartilhada. São Paulo: Editora Método, 2009, p. 343-358.

PERROT, Michelle (org.). História da vida privada, vol. 4: Da Revolução Francesa à Primeira Guerra. Trad. Denise Bottmann e Bernardo Joffily - São Paulo: Companhia das Letras, 2009.

PETRI, Maria José Constantino. O direito das crianças e adolescentes à convivência familiar e comunitária: responsabilidade da família, da comunidade e do Estado. Tese de Doutorado. Faculdade de Direito da Universidade de São Paulo. São Paulo, 2008.

PROST, Antoine; VINCENT, Gérard (org.). História da vida privada, vol. 5: Da Primeira Guerra a nossos dias. Trad. Denise Bottmann - São Paulo: Companhia das Letras, 2009.

RICHARDSON, Pamela. A kidnapped mind. Toronto: University of Toronto Press, 2006.

RIVA, Leia Comar; ROMANELLI, Geraldo. Negligência e cuidados parentais em famílias de baixa renda. In: CUNHA, Marcus Vinicius; PASIAN; Sonia Regina; ROMANELLI, Geraldo Romanelli (org.). Pesquisas em Psicologia: múltiplas abordagens. São Paulo: Vetor, 2009, p. 153-182. 
SAUBER, S. Richard. PAS as a family tragedy: roles of family members, professionals, and the Justice system. In: GARDNER, Richard A.; LORANDOS, Demosthenes; SAUBER, S. Richard (org.) The International Handbook of Parental Alienation Syndrome. 2nd ed. Springfield, IL : Charles C Thomas Publisher LTD, 2006, p. 12-32.

SCAFF, Fernando Campos. Considerações sobre o Poder Familiar. In: CHINELLATO, Silmara Juny; SIMÃO, José Fernando; FUJITA, Jorge Shiguemitsu; ZUCCHI, Maria Cristina (orgs.). Direito de Família no Novo Milênio: estudos em homenagem ao Professor Álvaro Villaça Azevedo. São Paulo: Atlas, 2010, p. 572-582.

SHINE, Sidney Kiyos. A espada de Salomão: a psicologia e a disputa de guarda de filhos. São Paulo: Casa do Psicólogo, 2003.

SILVA FILHO, Artur Marques. Adoção: regime jurídico, requisitos, efeitos, inexistência e anulação. 3. ed. rev. atual. e ampl. São Paulo: Ed. RT, 2011, p. 170-172.

SIMÃO, José Fernando; TARTUCE, Flávio. Curso de Direito Civil : Direito de Família. 5. ed. São Paulo: Editora Método, 2010.

SIMÃO, José Fernando. Ser ou não ser: outorga conjugal e solidariedade familiar. Revista Brasileira de Direito das Famílias e Sucessões. Porto Alegre, n. 3, p. 64, abr/mai de 2008.

SLHESSARENKO, Amanda Zoë. Uma visão sobre guarda de menor e direito de visita na sociedade contemporânea. Dissertação de Mestrado. Faculdade de Direito da Universidade de São Paulo. São Paulo, 2001.

SOTTOMAYOR, Maria Clara. Regulação do exercício do poder parental nos casos de divórcio. 2. ed. Coimbra : Livraria Almedina, 1998.

SOUZA, Analicia Martins. Síndrome da alienação parental - um novo tema nos juízos de família. São Paulo: Cortez, 2011.

SPOSATO, Karyna Batista. A constitucionalização do direito da criança no Brasil como barreira à redução da idade penal: visões de um neoconstitucionalismo aplicado. Revista Brasileira de Ciências Criminais, no 80, set. 2009, p. 80-118.

STRENGER, Guilherme Gonçalves. Guarda de filhos. São Paulo: LTr Ed., 1998.

TARTUCE, Flávio. Princípios constitucionais e Direito de Família. In: CHINELLATO, Silmara Juny; SIMÃO, José Fernando; FUJITA, Jorge Shiguemitsu; ZUCCHI, Maria Cristina (orgs.). Direito de Família no Novo Milênio: estudos em homenagem ao Professor Álvaro Villaça Azevedo. São Paulo: Atlas, 2010, p. 35-52.

TEPEDINO, Gustavo. A tutela constitucional da criança e do adolescente: projeções civis e estatutárias. In: CHINELLATO, Silmara Juny; SIMÃO, José Fernando; FUJITA, Jorge Shiguemitsu; ZUCCHI, Maria Cristina (orgs.). Direito de Família no Novo Milênio: 
estudos em homenagem ao Professor Álvaro Villaça Azevedo. São Paulo: Atlas, 2010, p. 415-435.

TEIXEIRA, Ana Carolina Brochado. A (des)necessidade da guarda compartilhada ante o conteúdo da autoridade parental. In: COLTRO, Antônio Carlos Mathias; DELGADO, Mário Luiz (coords.). Guarda Compartilhada. São Paulo: Editora Método, 2009, p. 17-40.

THÉRY, Irène. Couple, filiation et parenté aujourd'hui - Le droit face aux mutations de la famille et de la vie privée. Paris: Odile Jacob, 1998.

Le démariage - justice et vie privée. Paris: Odile Jacob, 1993.

TRINDADE, Jorge. Síndrome da Alienação Parental. In: DIAS, Maria Berenice (coord.). Incesto e Alienação Parental - realidades que a Justiça insiste em não ver. São Paulo: RT, 2007, p. 101-111.

WEISS, Telma Kutnikas. Guarda compartilhada: um olhar psicanalítico. In: COLTRO, Antônio Carlos Mathias; DELGADO, Mário Luiz (coords.). Guarda Compartilhada. São Paulo: Editora Método, 2009, p. 359-366.

ZERMATTEN, Jean. L'Intérêt Supérieur de l'Enfant De l'Analyse Littérale à la Portée Philosophique. Disponível em: http://www.childsrights.org/html/documents/wr/2003-3_fr.pdf. Acesso em 11.10.2011.

ZIMERMAN, Davi. Aspectos psicológicos da guarda compartilhada. In: COLTRO, Antônio Carlos Mathias; DELGADO, Mário Luiz (coords.). Guarda Compartilhada. São Paulo: Editora Método, 2009, p. 103-112. 